INSTITUTO DE PESQUISAS ENERGÉTICAS E NUCLEARES

Autarquia Associada à Universidade de São Paulo

\title{
ESTUDO PARA A OBTENÇÃO DE COMPÓSITO DO SISTEMA W-Cu-Ni APLICANDO A METALURGIA DO PÓ PARA USO COMO MATERIAL DE BLINDAGEM E ATENUAÇÃO DA RADIAÇÃO GAMA ( $Y)$
}

\author{
Francisco Carlos Cione
}

Tese apresentada como parte dos requisitos para o Grau de Doutor em Ciências na Área de Tecnologia Nuclear Materiais.

Orientador: Dr. Jesualdo Luiz Rossi 


\title{
INSTITUTO DE PESQUISAS ENERGÉTICAS E NUCLEARES
}

Autarquia Associada à Universidade de São Paulo

\begin{abstract}
Estudo para a obtenção de compósito do sistema W-Cu-Ni aplicando a metalurgia do pó para uso como material de blindagem e atenuação da rediação gama $(Y)$

\author{
Versão corrigida
}

\section{Francisco Carlos Cione}

Tese apresentada como parte dos requisitos para obtenção Grau de Doutor em Ciências na Área de Tecnologia Nuclear- Materiais.

Orientador: Dr. Jesualdo Luiz Rossi

\section{São Paulo}




\section{AGRADECIMENTOS}

Ao meu orientador Prof. Dr. Jesualdo Luiz Rossi, colaborador e paciente nas dúvidas mais elementares sobre metalurgia do pó. Amigo, com quem dividimos bons tempos e parte da minha trajetória na vida, compartilhando objetivos e trabalho para alcançar o sucesso desejado. Por sua presença constante e marcante no meu crescimento acadêmico, profissional e pessoal; deixo a minha mais profunda gratidão.

Aos amigos Professores, Dr. Armando Cirilo de Souza e Dr. Frank Ferrer Sene, por auxiliar, incentivar e colaborar na realização deste estudo, sempre com muita dedicação estiveram continuamente ajudando, trocando ideias e sugestões, esclarecendo dúvidas e contribuindo para o meu crescimento acadêmico e pessoal.

Aos dedicados amigos e professores do IPEN/CCTM; Dr. Cristiano Stefano Mucsi, Dr. Hidetoshi Takiishi, Dr. Luis Gallego Martinez, Dr. Rodolfo Politano, Dr. Xavier Turrillas, Dr. Ricardo Mendes Leal Neto, Dr. Egberto Galego, Dra. Marilene Morelli Serna por terem colaborado durante todo o processo de ensaios experimentais, disponibilizar equipamentos, laboratórios, instruções e literatura.

À Prof. Dra. Isolda Costa por suas amigáveis conversas, orientações em procedimentos experimentais e intensa colaboração cedendo a infraestrutura do Laboratório de Corrosão, para que assim fosse possível realizar parte dos ensaios experimentais empregados neste trabalho.

Às pesquisadoras e amigas Dra. Luzinete Pereira Barbosa e Dra. Clarice Terui Kunioshi pela dedicação especial no auxílio ao desenvolvimento das etapas de preparação de amostras e na metalografia, contribuindo com o meu aprendizado, em uma área tão importante da ciência dos materiais.

Ao amigo Mc Edson Pereira dos Santos do Laboratório de Materiais Magnéticos, por estar sempre disposto e próximo para ajudar a resolver as dificuldades de operação em fornos e prensas e pelo continuado suporte nos processos de obtenção das amostras.

À Prof. Dra. Márcia de Almeida Rizzuto, orientadora de Iniciação Científica, inspiradora e incentivadora para o universo da pesquisa acadêmica que sempre esteve disponível para dirimir dúvidas e questões emergentes deste estudo.

Ao colega técnico Alvimar Floriano de Sousa do Laboratório de Física da Matéria do Instituto de Física da USP, por sua disponibilidade em colaborar e dar sugestões na configuração, montagem e preparo dos equipamentos para coleta de dados para os procedimentos nos ensaios de atenuação da radiação.

Aos colegas, amigos e pesquisadores do Laboratório Aberto de Materiais, por Feixes 
lônicos do Instituto de Física da USP - LAMFI-USP, todos sempre auxiliando com extremo senso de colaboração e amizade com o valoroso espírito de fraternidade, sob o qual este trabalho pode ser realizado.

Aos meus filhos Karina Trajano Cione, Erika Trajano Cione, Marcelo Trajano Cione e Enrico Aniello Bernardes Cione; aos irmãos Eliana e Luis Carlos Cione por serem, sempre, a fonte inspiradora e motivadora na minha busca da continuada melhora como ser humano e a cada novo despertar, lutar para obter sucesso em um árduo, mas prazeroso, caminhar pela vida. Para Helena Vieira Trajano e Rosa Maria de Fátima Bernardes, mulheres que acompanharam parte da minha vida, como parceiras, e se tornaram mães de meus adoráveis filhos. E por último enfim, ainda que sempre presentes na minha vida, na mente e diante de todos os meus atos, faço deste trabalho parte da minha homenagem póstuma aos meus pais Terezinha Alves e Aniello Cione exemplos sempre presentes e aos quais, todos os dias, me encontro em pensamentos de gratidão.

Creio que se faz apropriado mencionar minha pessoal gratidão ao distinto Professor Dr. Pablo Pomerantzeff, cirurgião cardiovascular e Diretor da Unidade de Valvopatia do Instituto do Coração do HC da FMUSP que através de sua habilidade, seu talento e brilhantismo profissional, que no curso deste estudo interveio a favor da minha saúde física, possibilitando estender meu tempo de vida assim viabilizando para que eu possa estar entre as pessoas que amo, continuar a realizar meus sonhos e poder finalizar este estudo.

Agradecimentos à agência de fomento da Coordenação de Aperfeiçoamento de Pessoal de Nível Superior (CAPES) pelo suporte financeiro na modalidade de bolsa de estudos durante o período de realização deste estudo. Também sou grato ao Instituto de Pesquisas Energéticas e Nucleares (IPEN), a bolsa do Projeto Receptáculos de contenção de substâncias radiativas, Edital Pró-Estratégia 2058/2012. Em particular, agradeço o Centro de Ciência e Tecnologia dos Materiais (CCTM) por ceder sua ampla e completa estrutura de pesquisa sem a qual este trabalho não poderia ser realizado. 


\section{RESUMO}

CIONE, F. C. ESTUDO PARA A OBTENÇÃO DE COMPÓSITO DO SISTEMA WCU-Ni APLICANDO A METALURGIA DO PÓ PARA USO COMO MATERIAL DE BLINDAGEM E ATENUAÇÃO DA RADIAÇÃO GAMA (v), 2018. 157 p. Tese de doutorado - Instituto de Pesquisas em Energia Nuclear - IPEN. São Paulo

O compósito metálico do sistema tungstênio-cobre-níquel (W-Cu-Ni) produzido por metalurgia do pó (do inglês $P M$ - powder metallurgy) apresentou características adequadas para ser um material alternativo de uso na atenuação da radiação gama (Y). O chumbo e o urânio empobrecido são os materiais geralmente usados para a atenuação da radiação. Embora estes materiais apresentem uma certa toxidade e agressividade ao meio ambiente. Já os compósitos W-Cu-Ni não apresentam nem toxidade, nem riscos ambientais. $O$ tungstênio é o metal matriz do compósito que tem alta densidade atômica. Para a confecção das amostras deste material foi analisado e selecionado o tamanho das partículas dos pós-metálicos. Para homogeneizar a distribuição dos pós-metálicos e reduzir o tamanho médio de partículas foi utilizado: o moinho de esferas por 12, 24 e $36 \mathrm{~h}$. Na análise granulométrica, após a moagem foi observado tamanho médio de $12 \mu \mathrm{m}$. Na compactação das amostras foram usadas prensas: uniaxial e isostática, para obtenção dos compactados verde que foram sinterizadas em diferentes parâmetros de temperatura e pressão. Após a sinterização das amostras foi obtido o valor médio de 303,3 HV, nos ensaios de microdureza para a composição W6Cu1Ni, inédita neste propósito. A caracterização das amostras usou microscopia eletrônica de varredura (MEV) com EDS, indicando a formação da liga CuNi, responsável por consolidar a característica mecânica de sólido ao compósito WCu-Ni. Para medir a absorção da radiação nas amostras foi empregado método de experimentações por geometria de feixe estreito. Deste modo foi selecionada a fonte de radiação gama do cobalto-60, para estudar os efeitos e ajustes nos valores da camada semirredutora e (HLV) nas dimensões de espessura de blindagem necessária. Para o HLV, a amostra do compósito inédito W6Cu1Ni o método indicou a necessidade de 9,27 mm de espessura no de densidade obtida de $13,38 \mathrm{~g} \cdot \mathrm{cm}^{-3}$, superior a densidade obtida do chumbo $\left(11,25 \mathrm{~g}_{\mathrm{cm}}{ }^{-3}\right)$. Como comparativo foram utilizados os dados do banco XCOM (NIST), onde pode ser observada convergência entre os valores simulados de $9,15 \mathrm{~mm}$ e os valores experimentais obtidos.

Palavras chave: blindagem, atenuação, radiação, compósito, metalurgia do pó. 
CIONE, F. C. Study for the obtainment of the W-Cu-Ni system composite applying powder metalurgy for use as a radiation material and attenuation of gamma ray ( $\mathrm{Y}) .157$ p. Doctoral Thesis - Instituto de Pesquisas em Energia Nuclear - IPEN. São Paulo

\begin{abstract}
The metallic composite material of the tungsten-copper-nickel system (W-Cu-Ni) produced by powder metallurgy (P/M) presented adequade characteristics to be an alternative material for the attenuation of gamma $(\mathrm{Y})$ radiation. Lead and depleted uranium are the materials commonly used for radiation atenuattion. They are materials with certain toxicity and aggressiveness to the environment. The $\mathrm{W}-\mathrm{Cu}-\mathrm{Ni}$ composites are non-toxic and do not present environmental risks. The tungsten, matrix metal of the composite, has as property its atomic density that is directly proportional to the electrons of its atoms important for the purpose of radiation attenuation. For the preparation of the composite samples, the size of the metallic particles was determined and selected. In order to homogenize the metallic particle distribution and to reduce the average particle size, a ball mill was used for 12, 24 and 36 hours. After grinding, the particle size analysis presented the mean particle size of $12 \mu \mathrm{m}$ was observed. For compactation of the samples were used uniaxial and isostatic press to obtain green compacted then those were sintered in furnaces in different parameters of pressure and atmosphere. After the sintering step, in the micro-hardness tests an average of $303.3 \mathrm{HV}$ was achieved for the unpublished composition W6Cu1Ni used for radiation atenuattion. The characterization of the samples used scanning electron microscopy (SEM) with EDS indicating the formation of CuNi alloy responsible for consolidating the mechanical characteristic of solid to the $\mathrm{W}$-Cu-Ni composite. To measure the absorption of radiation in the samples the classical scientific method of narrow beam geometry (NBG) experiments was employed. The gamma radiation source of cobalt-60 was selected to study the effects and adjustments on the values of the Half-Value Layer and (HLV) in the dimensions of the required shielding thickness. For unpublished composite sample W6Cu1Ni the HLV method indicated the necessity of $9.27 \mathrm{~mm}$ of thickness in the obtained density of 13.38 g. $\mathrm{cm}^{-3}$, superior to the density of lead $\left(11,34 \mathrm{~g} . \mathrm{cm}^{-3}\right)$. As a comparative, database from the XCOM (NIST) were used and demostrating convergence between the simulated values of $9.15 \mathrm{~mm}$ and the experimental values.
\end{abstract}

Keywords: shielding, attenuation, radiation, tungsten composite, powder metallurgy. 


\section{SUMÁRIO}

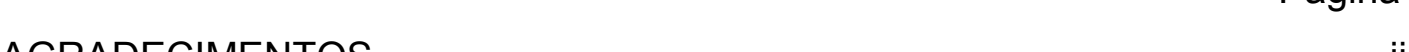

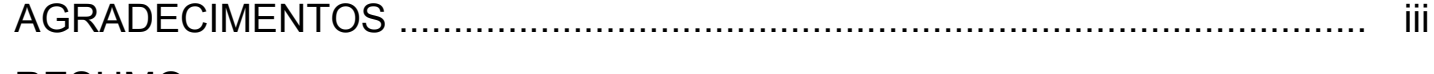

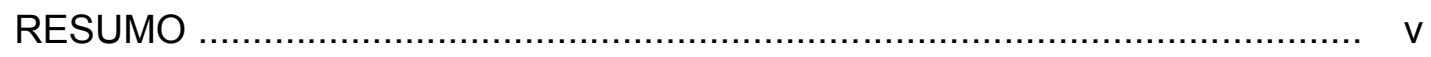

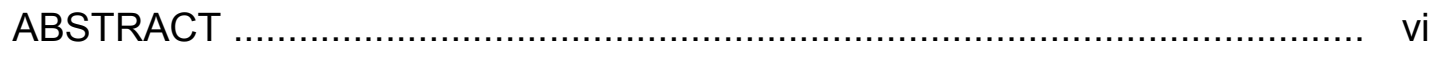

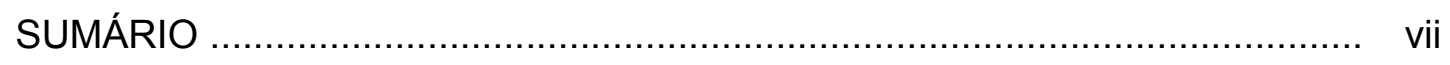

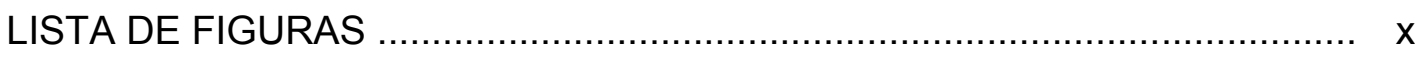

LISTA DE TABELAS …………….................................................. $\mathrm{xvii}$

LISTA DE SIGLAS …………………...............................................

1 INTRODUÇÃO

2 OBJETIVO E JUSTIFICATIVA …….............................................. 5

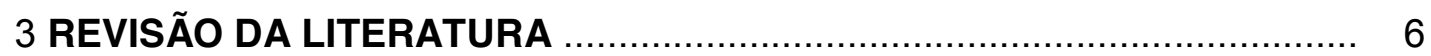

3.1 Normas aplicadas à produção nuclear .................................................. 6

3.1.1 Normas nacionais ..................................................................... 6

3.1.2 Normas internacionais .................................................................. 7

3.1.3 Transporte de materiais radioativos …………............................... 8

3.1.4 Normas de proteção radiológica …….............................................. 9

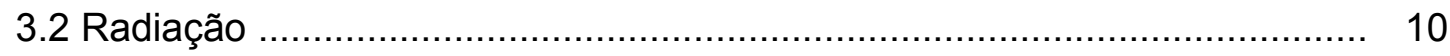

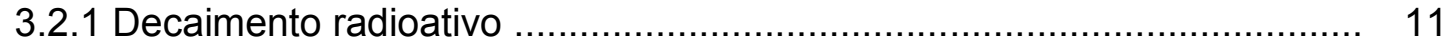

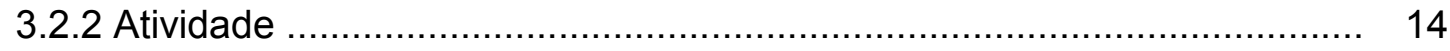

3.2.3 Estabilidade e radioatividade nuclear ............................................... 14

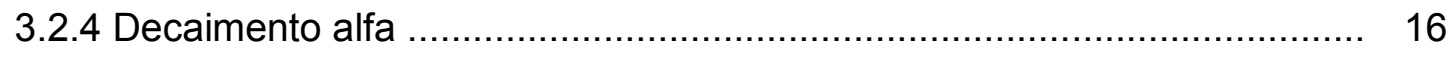

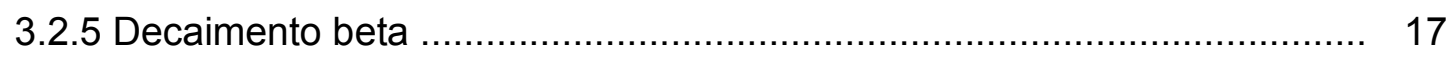

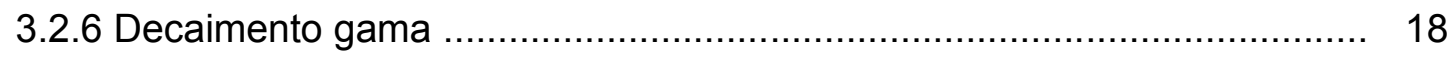

3.3 Interação da radiação com a matéria ...................................................... 18

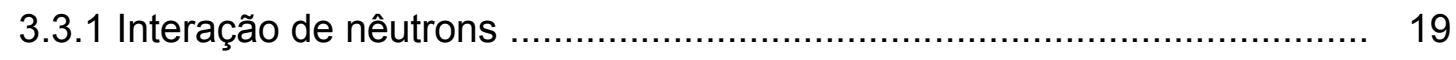

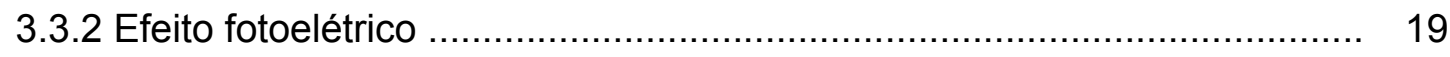

3.3.3 Efeito Compton ....................................................................... 20

3.3.4 Efeito produção de pares ............................................................. 21

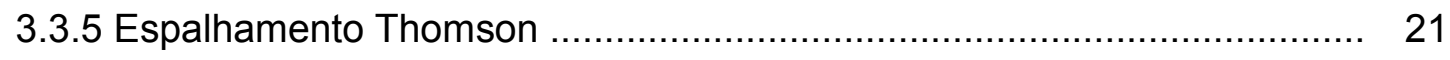

3.3.6 Absorção eletrônica .................................................................... 22

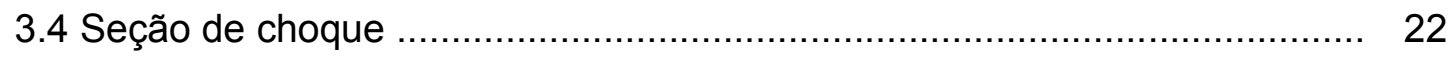

3.5 Atenuação da radiação .................................................................. 24

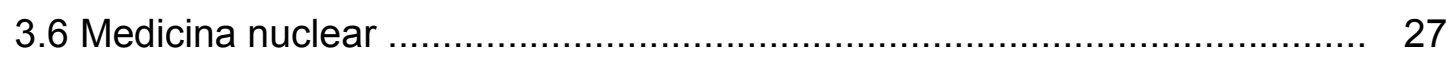




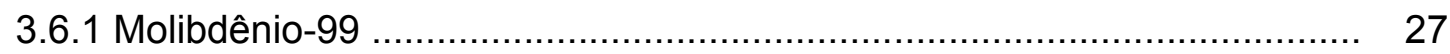

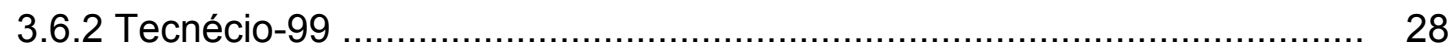

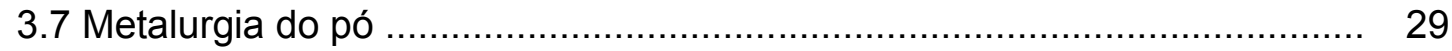

3.7.1 Obtenção de pós-metálicos ......................................................... 31

3.7.2 Propriedades dos pós-metálicos ...................................................... 31

3.7.3 Escoabilidade e empacotamento .................................................. 32

3.7.4 Mistura e moagem dos pós ............................................................. 33

3.7.5 Obtenção da liga Cu-Ni ............................................................... 34

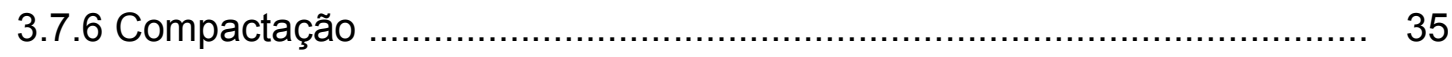

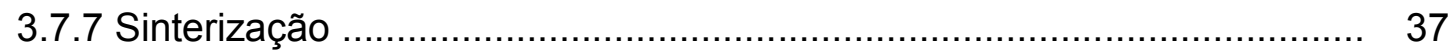

3.7.7.1 Sinterização em fase sólida ........................................................... 38

3.7.7.2 Sinterização em fase líquida ....................................................... 41

3.7.8 Obtenção dos compósitos de blindagem ............................................ 44

4 MATERIAIS E MÉTODOS …........................................................... 49

4.1 Matérias-primas ........................................................................... 50

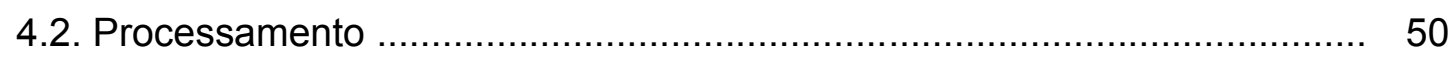

4.2.1 Escoabilidade dos pós …….......................................................... 51

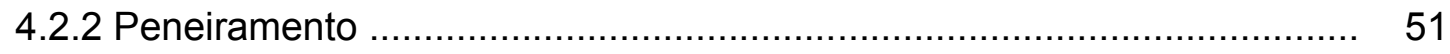

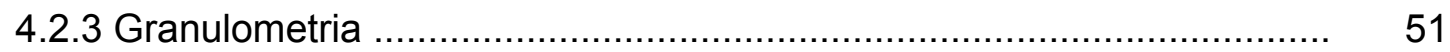

4.2.4 Microscopia eletrônica de varredura MEV ……................................... 51

4.2.5 Composição química ................................................................... 52

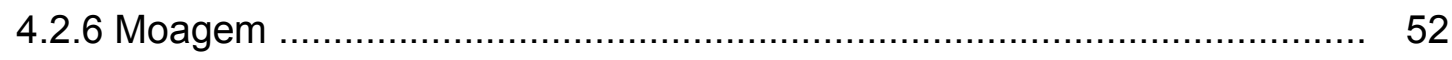

4.2.7 Preparação das misturas ................................................................ 53

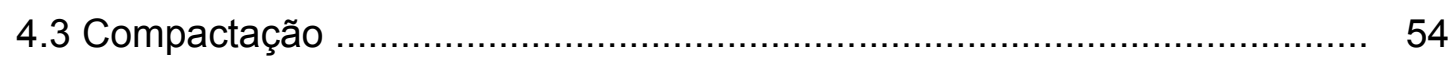

4.3.1 Compactação uniaxial .................................................................. 54

4.3.2 Compactação isostática ............................................................. 55

4.4 Sinterização ………................................................................... 55

4.4.1 Forno convencional ................................................................. 55

4.4.2 Forno industrial de esteira ........................................................ 55

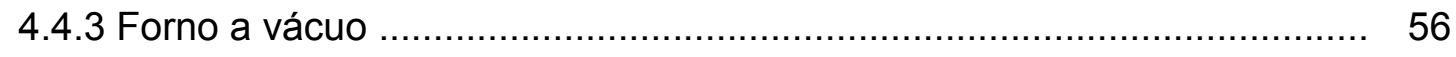

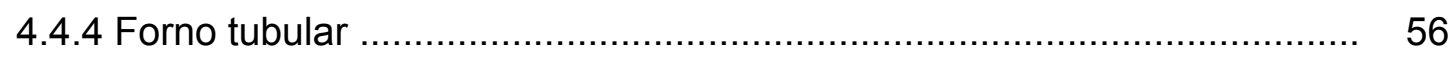

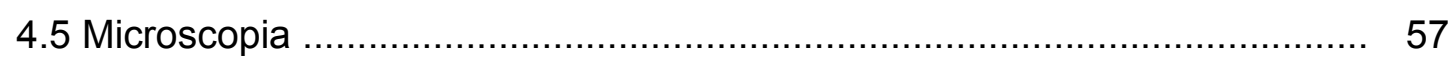

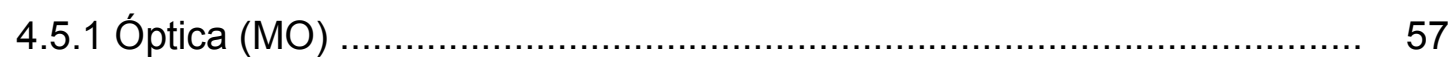

4.5.2 Microscopia MEV associada à EDS ………………........................ 57 
4.6 Caracterização da microdureza Vickers (HV) ...................................... 58

4.7 Ensaios de atenuação da radiação .................................................... 58

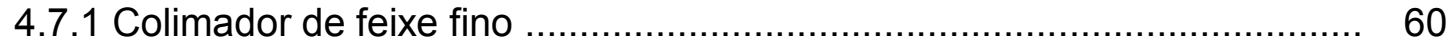

4.7.2 Sistema de aquisição de dados ...................................................... 60

5 RESULTADOS E DISCUSSÃO ……..................................................... 62

5.1 Características dos pós de partida ...................................................... 62

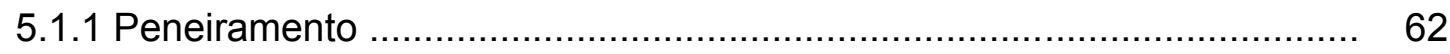

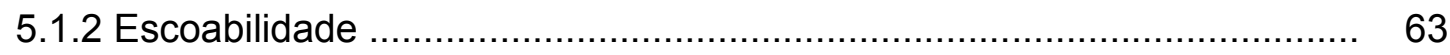

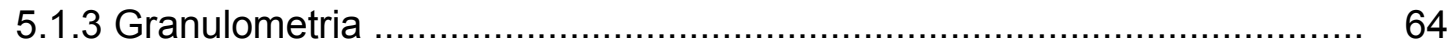

5.1.4 Fluorescência de raios X ...................................................... 72

5.1.5 Análise morfológica ................................................................. 74

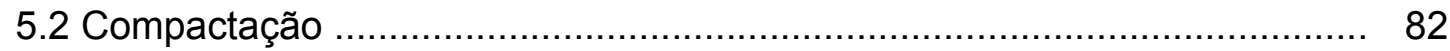

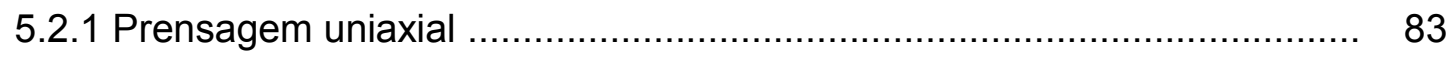

5.2.2 Prensagem uniaxial dupla ação .................................................... 87

5.2.3 Prensagem isostática ............................................................ 88

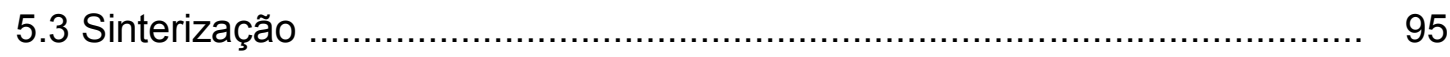

5.3.1 Sinterização ao ar ..................................................................... 95

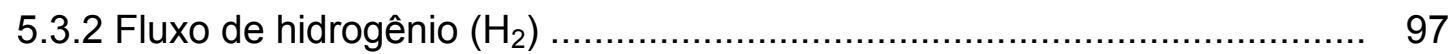

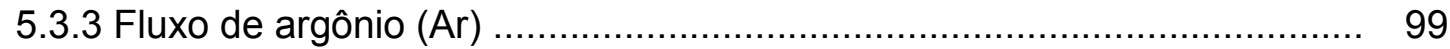

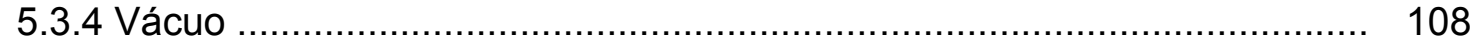

5.4 Ensaio de microdureza Vickers ....................................................... 113

5.5 Atenuação da radiação gama .......................................................... 115

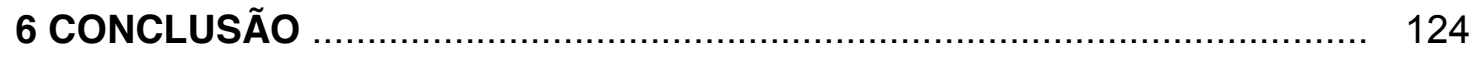

7 SUGESTÕES PARA TRABALHOS FUTUROS …................................. 127

REFERÊNCIAS BIBLIOGRÁFICAS ..................................................... 128 


\section{LISTA DE FIGURAS}

Página

Figura 1.1 - Imagem do embalado produzido e utilizado pela MDS - Nordion

Figura 1.2 - Adaptação do diagrama esquemático do embalado fabricado pela empresa norte-americana MDS, ilustrando em corte os componentes de blindagem contra a radiação

Figura 3.1 - Gráfico do decaimento por processos radioativos seguem uma lei de desintegração exponencial

Figura 3.2 - Gráfico da energia de ligação por núcleon em função do número de massa para região de estabilidade nuclear

Figura 3.3 - Gráfico dualog apresentando atenuação versus energia e probabilidades dos fenômenos envolvidos na seção de choque

Figura 3.4 - Diagrama de fase representativo da liga metálica do sistema Cu$\mathrm{Ni}$ apresentando a relação percentual em massa com as mudanças em propriedades decorrentes da temperatura

Figura 3.5 - Diagrama esquemático apresentando por German, propondo os cinco estágios possíveis de ocorrerem durante o processo de compactação

Figura 3.6 - Diagrama esquemático ilustrando os mecanismos de transporte e movimentação de átomos e lacunas na região de contato das partículas

Figura 4.1 - Fluxograma do processo de obtenção do compósito dos sistemas $\mathrm{W}-\mathrm{Cu}$ e $\mathrm{W}-\mathrm{Cu}-\mathrm{Ni}$ e das etapas para a caracterização de propriedades das amostras de material obtido e ensaios experimentais em atenuação e blindagem contra radiação

Figura 4.2 - Diagrama esquemático do moinho de bolas (esferas) utilizado no processo de moagem para obtenção do compósito dos sistemas W-Cu e W$\mathrm{Cu}-\mathrm{Ni}$

Figura 4.3 - Diagrama esquemático do ciclo de sinterização em forno industrial tipo de esteira contínua (adaptado de Neves [63])

Figura 4.4 - Diagrama ilustrativo do sistema de aquisição de dados para os ensaios experimentais de atenuação da radiação 
Figura 4.5 - Imagem ilustrativa do colimador de fonte feixe fino (a) detalhe da tampa porta amostra do colimador (b) conjunto colimador montado (c) amostra referência de tungstênio (d) porta amostra do colimador (e) parte superior do castelo do colimador (f) parte inferior do castelo do colimador ( $g$ ) detetor de radiação $(h)$ nicho e colimador

Figura 4.6 - Imagem ilustrativa da montagem do conjunto de equipamentos usado nos ensaio experimental

Figura 5.1 - Análise granulométrica (CILAS) para os pós de tungstênio cormo recebido

Figura 5.2 - Análise granulométrica (CILAS) para o pó de tungstênio após 36 $\mathrm{h}$ de moagem

Figura 5.3 - Análise granulométrica (CILAS) para os pós de cobre eletrolítico como recebido

Figura 5.4 - Análise granulométrica (CILAS) para os pós de cobre eletrolítico após moagem de $36 \mathrm{~h}$

Figura 5.5 - Análise granulométrica (CILAS) para os pós de cobre PAC como recebido

Figura 5.6 - Análise granulométrica (CILAS) para os pós de cobre PAC após moagem de $36 \mathrm{~h}$

Figura 5.7 - Análise granulométrica (CILAS) para o pó de cobre PAM como recebido

Figura 5.8 - Análise granulométrica (CILAS) do pó de cobre PAM após moagem de $36 \mathrm{~h}$

Figura5.9 - Análise granulométrica (CILAS) para o pó de níquel como recebido

Figura 5.10 - Análise granulométrica (CILAS) da composição de pós W-CuNi após moagem de $36 \mathrm{~h}$

Figura 5.11 - Distribuição do tamanho de partícula dos pós metálicos como informado, recebido e após 12 h, 24 h e 36 h de moagem

Figura 5.12 - Micrografia MEV mostrando a distribuição do tamanho de partícula para o pó de tungstênio como recebido

Figura 5.13 - Micrografia MEV detalhando tamanho forma e formação de aglomerados de partículas para o pó de tungstênio como recebido

Figura 5.14 - Micrografia MEV mostra a variação na distribuição do tamanho 
de partículas para o pó de tungstênio processado em moagem de $36 \mathrm{~h}$

Figura 5.15 - Micrografia MEV mostra a variação na distribuição do tamanho das partículas do pó de cobre eletrolítico como recebido

Figura 5.16 - Micrografia MEV mostra a forma dentrítica das partículas do pó de cobre eletrolítico como recebido

Figura 5.17 - Micrografia MEV mostra o tamanho de partículas para o pó de cobre eletrolítico processado em moagem de $36 \mathrm{~h}$ 77

Figura 5.18 - Micrografia MEV para o pó de cobre PAC como recebido 78

Figura 5.19 - Micrografia MEV mostra a formação de aglomerados de partículas do pó de cobre PAC como recebido

Figura 5.20 - Micrografia MEV mostra partículas formando aglomerados para o pó de cobre PAC processado em moagem de $36 \mathrm{~h}$

Figura 5.21 - Micrografia MEV mostra a distribuição do tamanho de partículas para o pó de cobre PAM como recebido

Figura 5.22 - Micrografia MEV mostra a formação de aglomerados de partículas do pó de cobre PAM

Figura 5.23 - Micrografia MEV mostra o tamanho de partículas para o pó de cobre PAM processado em moagem de $36 \mathrm{~h}$

Figura 5.24 - Micrografia MEV mostra a uniformidade na distribuição do tamanho de partículas para o pó de níquel como recebido

Figura 5.25 - Micrografia MEV mostra a uniformidade na distribuição do tamanho de partículas para o pó de níquel

Figura 5.26 - Micrografia MEV mostra o tamanho de partículas para o pó de níquel processado em moagem de $36 \mathrm{~h}$

Figura 5.27 - Gráfico representando o comportamento de densificação das misturas W-Cu-Ni obtidas por compactação a 90 MPa, 180 MPa e 270 MPa ..

Figura 5.28 - Gráfico representando o comportamento de densificação das misturas W-Cu obtidas durante a compactação a $90 \mathrm{MPa}, 180 \mathrm{MPa}$ e 270 MPA em prensa uniaxial convencional

Figura 5.29 - Gráfico representando o comportamento de densificação das misturas obtidas em compactação a $480 \mathrm{MPa}, 520 \mathrm{MPa}$ e $680 \mathrm{MPa}$ em prensa uniaxial dupla ação

Figura 5.30 - Gráfico representando o comportamento de densificação das 
misturas obtidas em compactação a $480 \mathrm{MPa}, 520 \mathrm{MPa}$ e $680 \mathrm{MPa}$ em prensa uniaxial dupla ação

Figura 5.31 - Gráfico representando o comportamento de densificação das misturas W-Ni em compactação isostática em pressões de 190 MPa e 210 $\mathrm{MPa}$

Figura 5.32 - Gráfico representando o comportamento de densificação das misturas W-Cu-Ni em compactação isostática em pressões de 190 MPa e $210 \mathrm{MPa}$

Figura 5.33 - Gráfico representando o comportamento de densificação das misturas W-Cu-Ni em compactação isostática em pressões de 190 MPa e $210 \mathrm{MPa}$

Figura 5.34 - Gráfico representando o comportamento de densificação das misturas W-Cu-Ni obtidas em compactação isostática a $190 \mathrm{MPa}, 210 \mathrm{MPa}$...

Figura 5.35 - Gráfico representando o comportamento de densificação das misturas W-Cu-Ni em compactação isostática em pressões de 190 MPa e $210 \mathrm{MPa}$

Figura 5.36 - Gráfico representando o comportamento de densificação das misturas W-Cu-Ni em compactação isostática em pressões de 190 MPa e $210 \mathrm{MPa}$

Figura 5.37 - Imagem ilustrativa de amostras da composição W-Cu oxidada

Figura 5.38 - Micrografia óptica da amostra de composição W-Cu oxida

Figura 5.39 - Micrografia ótica da superfície da amostra do sistema W-Cu sinterizada em forno industrial de esteira

Figura 5.40. - Micrografia ótica da amostra W20Cu após a sinterização em forno com atmosfera $\left(80 \mathrm{~N}_{2} 2 \mathrm{H}_{2}\right)$ em forno industrial de esteira

Figura 5.41 - Micrografia ótica da amostra do sistema W10Cu1,5Ni após a sinterização em forno industrial esteira com atmosfera $\left(80 \mathrm{~N}_{2} 20 \mathrm{H}_{2}\right)$.

Figura 5.42 - Micrografia ótica da amostra do sistema W10Cu1Ni após a sinterização em forno industrial esteira com atmosfera $\left(80 \mathrm{~N}_{2} 20 \mathrm{H}_{2}\right)$

Figura 5.43 - Micrografia ótica da amostra de mistura W10Cu1Ni após a sinterização forno industrial esteira com atmosfera $\left(80 \mathrm{~N}_{2} 20 \mathrm{H}_{2}\right)$ 100

Figura 5.44 - Micrografia MEV da amostra W10Cu1Ni apresentando a região 
da fase líquida CuNi (particulado fino) e da fase composta por particulados de tungstênio (particulado grosso)

Figura 5.45 - Espectro de energia dispersiva (EDS) na região de tungstênio (W) da amostra W10Cu1Ni

Figura 5.46 - Espectro de energia dispersiva (EDS) na região do cobreníquel (CuNi) da amostra W10Cu1Ni

Figura 5.47 - Micrografia ótica da superfície da amostra de composição W8Cu1Ni

Figura 5.48 - Micrografia MEV da amostra W8Cu1Ni representando as regiões da fase líquida $\mathrm{CuNi}$ (cinza escuro) e da fase composta por particulados grossos e aglometrados finos de tungstênio (cinza claro)

Figura 5.49 - Espectro de energia dispersiva (EDS) na região CuNi da amostra W8Cu1Ni

Figura 5.50 - Espectro de energia dispersiva (EDS) na região do tungstênio (W) da amostra W8Cu1Ni

Figura 5.51 - Micrografia ótica da superfície da amostra de composição W6Cu1Ni

Figura 5.52 - Micrografia MEV da amostra da mistura W6Cu1Ni na região da fase líquida CuNi (região escura) e da fase composta por particulados de tungstênio (região clara)

Figura 5.53 - Espectro de energia dispersiva (EDS) na região CuNi da amostra W6Cu1Ni

Figura 5.54 - Espectro de energia dispersiva (EDS) na região do tungstênio (W) da amostra W6Cu1Ni

Figura 5.55 - Micrografia óptica na região de borda da amostra de composição $\mathrm{W} 1 \mathrm{Ni}$

Figura 5.56 - Micrografia MEV da região de borda da amostra de composição W1Ni

Figura 5.57 - Espectro de energia dispersiva (EDS) mostrando a composição química na região de borda da amostra W1Ni

Figura 5.58 - Espectro de energia dispersiva (EDS) representando a região de predominância do níquel sobre a amostra da mistura $\mathrm{W} 1 \mathrm{Ni}$

Figura 5.59 - Regiões utilizadas para ensaios de microdureza Vickers na superfície e na região do corte transversa I-AB das amostras das misturas do 
sistema W-Cu-Ni

Figura 5.60 - Amostra W6Cu1Ni (a) como sinterizada (b) seção de corte (c) embutida e polida para caracterização por metalografia

Figura 5.61 - Gráfico do espectro resultante do ensaio experimental em tempo de 2000 segundos ilustrativo dos valores de calibração canal em detetor e energia da radiação e como fonte a radiação de fundo (espectro de branco) para ajuste de contagens

Figura 5.62 - Gráfico do espectro resultante do ensaio experimental em tempo de 1700 segundos de atenuação da radiação ilustrando os dois picos (1173 keV, $1332 \mathrm{keV}$ ) para a fonte radioativa de Co-60 distante $100 \mathrm{~mm}$ do detector sem material de atenuação, livre caminho no ar

Figura 5.63 - Gráfico do espectro resultante do ensaio experimental de atenuação da radiação da amostra $\mathrm{W} 10 \mathrm{Cu} 1 \mathrm{Ni}$

Figura 5.64 - Gráfico do espectro resultante do ensaio experimental de atenuação da radiação da amostra $\mathrm{W} 8 \mathrm{Cu} 1 \mathrm{Ni}$

Figura 5.65 - Gráfico do espectro resultante do ensaio experimental de atenuação da radiação da amostra $\mathrm{W} 6 \mathrm{Cu} 1 \mathrm{Ni}$

Figura 5.66 - Gráfico do espectro resultante do ensaio experimental de atenuação da radiação da amostra de composição W1Ni 
Tabela 3.1 - Decaimentos meia-vida dos isótopos do urânio por fissão espontânea

Tabela 4.1 - Identificação dos pós-metálicos e características de como recebido

Tabela 4.2 - Composição nominal em massa das misturas do sistema W-Cu, W-Cu-Ni e W-Ni após moagem

Tabela 5.1 - Determinação da distribuição de tamanho de partículas por peneiramento como recebido

Tabela 5.2 - Determinação da distribuição de tamanho de partículas por peneiramento depois de moído

Tabela 5.3 - Resultado da análise de taxa de fluxo para os pós de tungstênio, cobre e níquel como recebido e após $36 \mathrm{~h}$ de ação de moagem

Tabela 5.4 - Valores obtidos para densidade aparente (solta) e batida (tapped density) os pós de tungstênio, cobre e níquel como recebido

Tabela 5.5 - Resultado da análise granulometria (CILAS) do tamanho de partículas dos pós de tungstênio, cobre e níquel como recebido

Tabela 5.6 - Resultado da análise granulometria (CILAS) do tamanho de partículas dos pós de tungstênio, cobre e após $36 \mathrm{~h}$ de moagem

Tabela 5.7 - Dados de análise por fluorescência de raios $X$ da composição química dos pós de partida

Tabela 5.8 - Densidade média a verde $\left(\overline{D_{v}}\right)$ para as composições de misturas do sistema W-Cu-Ni em função da pressão de compactação de 90 $\mathrm{MPa}, 180 \mathrm{MPa}$ e $270 \mathrm{MPa}$

Tabela 5.9 - Densidade média a verde $\left(\overline{D_{v}}\right)$ em função da pressão de compactação do conjunto de misturas do sistema W-Cu-Ni

Tabela 5.10 - Densidade média a verde $\left(\overline{D_{v}}\right)$ em função da pressão de compactação do conjunto de misturas do sistema W-Cu-Ni compactadas sob pressões de $180 \mathrm{MPa}, 270 \mathrm{MPa}, 480 \mathrm{MPa}$ e $650 \mathrm{MPa}$.

Tabela 5.11 - Densidade média a verde $\left(\overline{D_{v}}\right)$ para as pressões de $520 \mathrm{MPa}$ e $650 \mathrm{MPa}$ em prensagem uniaxial dupla ação

Tabela 5.12 - Densidade média a verde $\left(\overline{D_{v}}\right)$ para o conjunto de misturas do sistema W-Ni em função da pressão de compactação isostática de $190 \mathrm{MPa}$, 
Tabela 5.13 - Densidade média a verde $\left(\overline{D_{v}}\right)$ para o conjunto de misturas do sistema W-Cu-Ni em função da pressão de compactação compactadas por pressão isostática de $190 \mathrm{MPa}$, e $210 \mathrm{MPa}$

Tabela 5.14 - Densidade média a verde $\left(\overline{D_{v}}\right)$ para o conjunto de misturas do sistema W-Cu-Ni em função da pressão de compactação compactadas por pressão isostática de $190 \mathrm{MPa}$ e $210 \mathrm{MPa}$

Tabela 5.15 - Densidade média a verde $\left(\overline{D_{v}}\right)$ para o conjunto de misturas do sistema W-Cu-Ni em função da pressão de compactação compactadas por pressão isostática de $190 \mathrm{MPa}$, e $210 \mathrm{MPa}$

Tabela 5.16 - Densidade média a verde $\left(\overline{D_{v}}\right)$ para o conjunto de misturas do sistema W-Cu-Ni em função da pressão de compactação compactadas por pressão isostática de $190 \mathrm{MPa}$ e $210 \mathrm{MPa}$

Tabela 5.17 - Densidade média a verde $\left(\overline{D_{v}}\right)$ para o conjunto de misturas do sistema W-Cu-Ni em função da pressão de compactação compactadas por pressão isostática de $190 \mathrm{MPa}$ e $210 \mathrm{MPa}$

Tabela 5.18 - Dados de composição química por EDS da região CuNi da amostra W10Cu1Ni

Tabela 5.19 - Dados de composição química por EDS da amostra W8Cu1Ni

Tabela 5.20 - Dados de composição química por EDS da amostra W6Cu1Ni

Tabela 5.21 - Dados de composição química por EDS da região de tungstênio $(\mathrm{W})$ da amostra $\mathrm{W} 1 \mathrm{Ni}$.....

Tabela 5.22 - Dados por EDS de composição química da amostra W1Ni na região de predominância de níquel (142)

Tabela 5.23 - Dados dos valores de microdureza Vickers obtido nos ensaios de laboratório para as amostras de misturas de sinterizados do sistema WCu-Ni

Tabela 5.24 - Valores das intensidades obtidas para a média dos picos de energia da radiação do Cobalto-60 para as amostras $\mathrm{W} 10 \mathrm{Cu} 1 \mathrm{Ni}$

Tabela 5.25 - Valores das intensidades obtidas para a média dos picos de energia da radiação do Cobalto-60 para as amostras W8Cu1Ni

Tabela 5.26 - Valores das intensidades obtidas para a média dos picos de 
energia da radiação do Cobalto-60 para as amostras $\mathrm{W} 6 \mathrm{Cu} 1 \mathrm{Ni}$

Tabela 5.27 - Valores das intensidades obtidas para a média dos picos de energia da radiação do Cobalto-60 para as amostras $\mathrm{W} 1 \mathrm{Ni}$

Tabela 5.28 - Propriedades das amostras de referência (WinXCOM Database)

Tabela 5.29 - Coeficientes Linear de Absorção $(\mu)$ dos elementos utilizados na composição do sistema W-Cu-Ni relacionados por energia da radiação gama do cobalto-60 pelo database NIST

Tabela 5.30 - Valores comparativos de espessura para atenuação de camada semi-redutora (HVL) dos elementos referência e de composição do sistema W-Cu-Ni e W-Ni 


\section{LISTA DE SIGLAS}

Sigla Descrição

ABNT Associação Brasileira de Normas Técnicas

ASTM Sociedade Americana para Testes e Materiais (American

Society for Testing and Materials)

EDS Espectro de Energia Dispersiva

FWHM Largura à meia altura (full width at half maximum)

HVL Camada semi-redutora (Half Value Layer)

ISO Organização Internaciona de Padrões (International Standard Organization)

NBG Geometria de Feixe Estreito ou Fino (Narrow Beam Geometry)

PAC Cobre em pó de fabricação Metalpó por técnica de atomização com auxílio de jato de água.

PAM Cobre em pó de fabricação Metalpó por técnica de atomização com auxílio de jato a gás.

MEV Microscópio Eletrônico de Varredura

MO Microscopia Óptica

W-Cu Composição do sistema tungstênio (W) e cobre (Cu)

W-Cu-Ni Composição do sistema tungstênio $(\mathrm{W})$, cobre $(\mathrm{Cu})$ níquel $(\mathrm{Ni})$

W-Ni Composição do sistema tungstênio (W) e níquel (Ni) 


\section{INTRODUÇÃo}

O Brasil vem experimentando uma crescente demanda de radiofármacos. O que se produz não é suficiente para atender a demanda, assim importa-se parte substancial destes insumos para atender o consumo. Em maio de 2009, a empresa canadense MDS Nordion passou por problemas técnicos em suas instalações que implicaram em crises no fornecimento de radionuclídeos e radiofármacos provocando desabastecimento no setor. As interrupções na importação e fornecimento dos radionuclídeos causou grande impacto nos atendimentos médicos e mostrou a grande fragilidade e dependência externa destes produtos. A maior parte da produção de radiofármacos está concentrada em países que dominam a tecnologia, particularmente a nuclear, operando reatores nucleares e aceleradores de partículas. Os radionuclídeos necessários para atender a produção dos radiofármacos são transportados para serem beneficiados e fracionados pelo Centro de Radiofarmácia do IPEN-CNEN/SP $[1,2]$.

O Brasil foi diretamente afetado pelo desabastecimento, o que resultou na elevação de preços dos radionuclídeos e afetou diretamente a disponibilidade de radiofármacos, principalmente o molibdênio-99 $\left({ }^{99} \mathrm{Mo}\right)$ utilizado na produção dos geradores de tecnécio pelo IPEN. Os geradores de tecnécio $\left({ }^{99 m} \mathrm{Tc}\right)$ são produzidos pelo IPEN e usados para se obter imagem do coração, cérebro, fígado, pulmão e outros órgãos além do sistema ósseo com finalidade diagnóstica $[3,4]$. Para o transporte do Mo-99 são utilizados equipamentos do tipo embalado, ou no termo em inglês cask (FIG. 1.1).

Figura 1.1 Imagem do embalado produzido e utilizado por MDS-Nordion [3].

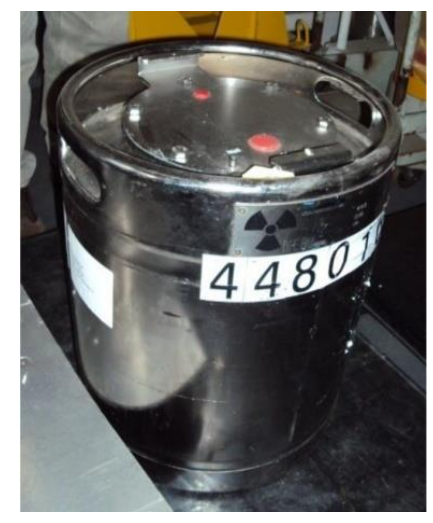

Fonte: retirada pelo autor 
A produção e também a certificação para o uso dos embalados de transporte representa uma grande dificuldade técnica para a indústria nacional. Deste modo a figura (FIG. 1.2). mostra o desenho esquemático, assim como as partes que compõe os embalados produzidos e fornecidos pelo fabricante MDS.

Figura 1.2 Adaptação do diagrama esquemático do embalado fabricado pela empresa norteamericana MDS, ilustrando em corte os componentes de blindagem contra a radiação [3].

Dimensões:

\begin{tabular}{cccc}
\hline Modelo & $\begin{array}{c}\text { Peso total } \\
(\mathrm{kg})\end{array}$ & $\begin{array}{c}\text { Diâmetro } \\
(\mathrm{mm})\end{array}$ & $\begin{array}{c}\text { Altura } \\
(\mathrm{mm})\end{array}$ \\
\hline F-458/F-251 & 167,0 & 184,0 & 274,0 \\
\hline F-458/F-318 & 164,0 & 171,0 & 268,0 \\
\hline
\end{tabular}

1- Tampa superior removível do cilindro composto por aço inox e espuma de poliuretano (antichoque e isolação térmica).

2- Cilindro principal composto por aço inox e espuma de poliuretano (antichoque e isolação térmica).

3- Vaso de blindagem (urânio empobrecido F458).

4- Tampa de contenção do vaso de blindagem (urânio empobrecido - F458).

5- Anel (gasket) de neoprene.

6- Tampa do vaso hermética.

7- Vaso hermético.

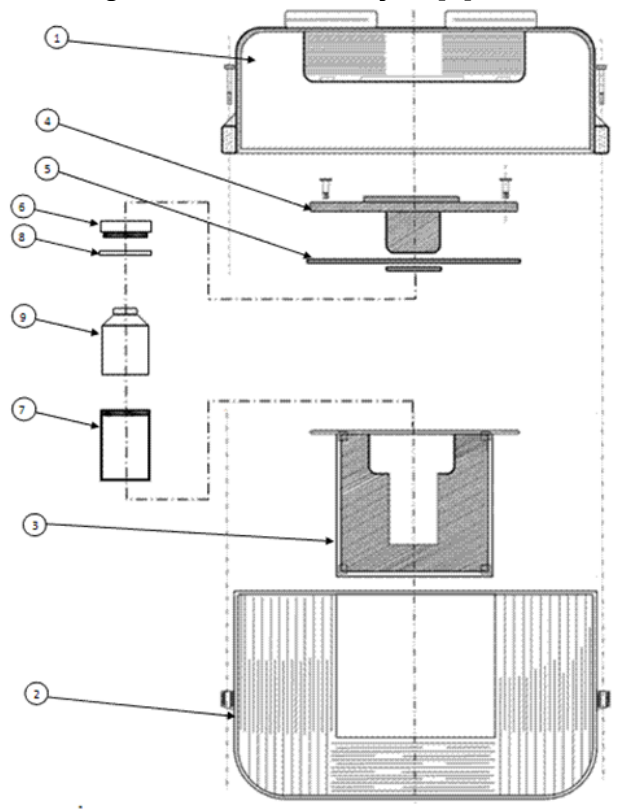

Fonte: German Authority US Department of Transportation

O projeto do Reator Multipropósito Brasileiro (RMB) tem como objetivo promover autossuficiência na produção de radioisótopos, desenvolvimento de tecnologias e pesquisa científica. Para atender à futura produção e distribuição de radiofármacos do RMB é necessário desenvolver e nacionalizar as técnicas de fabricação destes equipamentos, necessários ao atendimento e o suporte na produção de radiofármacos. $\mathrm{O}$ equipamento embalado ao ser nacionalizado deve prever a possibilidade de uso também para o transporte internacional, devendo assim atender as normas da CNEN além de atender as Normas adotadas pelas agências de regulamentação internacionais e estar em conformidade com princípios do ALARA (As Low As Reasonable Achieved) [5,6].

Neste contexto surgiu a necessidade do desenvolvimento de um material de blindagem contra a radiação alternativo ao chumbo e urânio empobrecido. Este estudo que foi orientado para obter um compósito do sistema tungstênio (W), como matriz e os pós de cobre $(\mathrm{Cu})$ e níquel $(\mathrm{Ni})$, como sinterizados na fase 
líquida pela técnica de metalurgia do pó (M/P) que atende esta necessidade. $O$ compósito obtido pode ser aplicado como material de blindagem contra a radiação gama, na confecção de embalados para transporte do radionuclídeo molibdênio99, podendo também ser utilizado em dispositivos estacionários. Logo, foram investigadas algumas das propriedades mecânicas do material compósito do sistema W-Cu-Ni e também buscou-se obter o coeficiente linear de atenuação da radiação gama. O aspecto diferencial para a utilização da metalurgia do pó na obtenção deste componente é factível. Outra vantagem é a apresentação das peças produzidas em sua forma quase final, near net shape, que implica na possibilidade de controle da densidade, reprodução dimensional e a facilidade de automação dos processos produtivos.

O tungstênio foi o pó-metálico matriz escolhido, por ter como principal propriedade: a elevada densidade atômica que é importante na função de material absorvedor de energia da radiação eletromagnética (fótons de comprimento gama e raios $\mathrm{X}$ ) e de partículas (alfa, beta e nêutrons). É bastante comum o uso de materiais de alta densidade atômica tais como, o chumbo e o urânio empobrecido, para a confecção de dispositivos de blindagem contra a radiação utilizados em equipamentos que operam com uso de fontes radioativas. A propriedade de alta densidade destes materiais está associada à alta densidade eletrônica de seus átomos. É no campo de elétrons (eletrosfera) do átomo que ocorrem os principais fenômenos de interação com a matéria e que causam a absorção de energia dos fótons da radiação. As ocorrências de interação com o núcleo (captura de elétrons e nêutrons) também são possíveis, porém são raras em função da alta energia necessária envolvida nestes processos. Dessa forma, faz-se necessário, o estudo mais detalhado do material a ser empregado, como a blindagem, em função da radiação envolvida pois ocorrem fenômenos secundários em função desta interação. O urânio empobrecido não deve ser usado para blindagem de nêutrons, porque existe a possibilidade de ocorrer reações danosas de fissão.

Os materiais do sistema Cu-Ni, acima mencionados, são de fácil obtenção na forma de pó, pelo uso das técnicas de atomização e eletroquímica. Estes pósmetálicos têm propriedades físico-químicas que permitem fácil conformação por processo de fundição, ou com uso da tecnologia de metalurgia do pó. O tungstênio metálico em pó é geralmente obtido por via da redução química de seus óxidos $\left(\mathrm{W}_{\mathrm{x}} \mathrm{O}_{\mathrm{y}}\right)$. Contudo o tungstênio tem elevada densidade $\left(19,25 \mathrm{~g} \cdot \mathrm{cm}^{-3}\right)$ e 
esta propriedade o torna um material excelente para uso como atenuador de radiação gama. A dificuldade no uso do tungstênio está em seu alto ponto de fusão $\left(3.442{ }^{\circ} \mathrm{C}\right)$ que dificulta as técnicas convencionais de fusão em fornos e inviabiliza as aplicações onde o baixo custo é mandatório. Materiais como o chumbo e o urânio empobrecido estão sendo abandonados como escolhas para o uso em blindagem, principalmente em equipamentos de transporte. As razões apresentadas para que não se use estes materiais é a grande dificuldade em se obter urânio empobrecido no Brasil; e para o chumbo sua baixa temperatura de fusão que poderia provocar perda da capacidade de blindagem, em caso de acidente com fogo em transporte, provocando direta contaminação ambiental e exposição da fonte de radiação. Por decorrência das propriedades do tungstênio é que ele e suas ligas têm sido utilizados em diversas soluções na indústria mecânica, eletroeletrônica e também passaram a ser usadas em equipamentos da indústria nuclear. Nas questões da maior segurança e afinidade ecológica, o tungstênio passa a ter vantagens positivas para a aplicação como elemento de blindagem, em equipamentos móveis ou estacionários da indústria nuclear.

Como resultado no desenvolvimento deste trabalho foi possível obter o compósito metálico do sistema W-Cu-Ni, que pode ser utilizado como material de blindagem. O compósito obtido é um material alternativo de possível aplicação em equipamentos de transporte de substâncias radioativas ou em aplicações estacionárias de radioproteção, atenuando energia da radiação para a faixa de 10 $\mathrm{keV}$ a $10^{5} \mathrm{keV}$. A viabilidade de produção pela indústria nacional por tecnologia da metalurgia do pó mostrou-se economicamente viável. As razões apontadas são o baixo custo estimado no processo de manufatura, a economia de material aplicado e a baixa complexidade da planta industrial necessária para aplicação das técnicas empregadas. Associado a estas razões pode-se ressaltar o atendimento às práticas de proteção e sustentabilidade ao meioambiente e aos critérios das normativas de segurança nacionais emitidas para a produção na Comissão Nacional de Energia Nuclear (CNEN) e compatibilidade com as normativas internacionais da International Atomic Energy Agency (IAEA). 


\section{OBJETIVO E JUSTIFICATIVA}

O objetivo deste estudo foi pautado na obtenção de compósito do sistema W-Cu-Ni, produzido por metalurgia do pó para ser aplicado como material alternativo ao chumbo e ao urânio empobrecido que são os materiais geralmente utilizados na blindagem contra a radiação gama. Como fator inédito e original contido neste trabalho, apresenta-se o compósito metálico $\mathrm{WxCuyNi,} \mathrm{para} \mathrm{a}$ blindagem contra a radiação e que ainda não foi veiculado na literatura técnica, ou acadêmica.

A motivação deste estudo veio associada às diretrizes do processo número 2058/12 do edital CAPES Pró-Estratégia. Neste contexto, este trabalho foi desenvolvido parcialmente vinculado ao projeto que tem por objetivo a fabricação de equipamento do tipo embalado para transporte de substâncias radioativas, tipo radiofármacos para a medicina nuclear. 


\section{REVISÃO DA LITERATURA}

\subsection{Normas aplicadas à produção nuclear}

O Brasil segue tratados internacionais nos quais a existência de normas e regulamentações direcionam o uso pacífico da energia nuclear. É na Constituição da República Federativa de 1988 em que estão as diretrizes sobre energia nuclear. Diz em seu artigo número 177, que constituem monopólio da União:

$\mathrm{V}$ - a pesquisa, a lavra, o enriquecimento, o reprocessamento, a industrialização e o comércio de minérios e minerais e seus derivados, com exceção dos radioisótopos cuja produção, comercialização e utilização poderão ser autorizadas sob regime de permissão, conforme as alíneas b e c do inciso XXIII do caput do art. 21 desta Constituição Federal (redação dada pela Emenda Constitucional n. 49, de 2006).

E ainda, de acordo com o artigo número 21, compete à União no quesito de segurança, a responsabilidade civil por danos nucleares: "a responsabilidade civil por danos nucleares independente da existência de culpa" (incluída pela Emenda Constitucional n. 49, de 2006) $[7,8]$.

\subsubsection{Normas nacionais}

A Comissão Nacional de Energia Nuclear (CNEN) é o principal órgão responsável pelo controle e a regulamentação de materiais radioativos e nucleares no Brasil. É a CNEN que elabora, aplica e fiscaliza as normas sobre o uso e exerce controle sobre as atividades relativas à energia nuclear. A CNEN que elabora normas e o controle que também se aplicam ao transporte de substâncias radioativas e aos equipamentos nele utilizados. A Comissão Nacional de Energia Nuclear (CNEN), em 1988, editou o Termo de referência de Norma 30.1 e a Norma CNEN-NE-5.01 que define os requisitos de segurança e cuidados com o transporte de cargas radioativas $[9,10]$. Já, a Norma CNEN 6.02 criada pela Resolução 166 , de 16 de abril de 2014, estabelece os requisitos para o licenciamento de instalações radiativas, em que dentre outros itens, dispõe sobre distribuição e armazenamento de fontes de radiação ionizante [11]. Além do regulamento da CNEN, a Resolução 420 da ANTT (Agência Nacional de Transportes Terrestres) instrui sobre o transporte de materiais radioativos suas 
necessidades e o dever de atender aos documentos normativos publicados pelas agências reguladoras do transporte modal [12]. Na área de transporte por avião, a Agência Nacional de Aviação Civil (ANAC) editou a resolução RBAC 175 que descreve e estabelece os requisitos aplicáveis ao transporte aéreo doméstico e internacional de artigos perigosos em aeronaves civis [13]. A NORMAM 01, 02 e 29 da Diretoria de Portos e Costas da Marinha do Brasil e Resolução 1765 da ANTAQ (Agência Nacional de Transportes Aquaviários) de julho de 2010, datou e aprovou a norma de procedimentos para o trânsito seguro de produtos perigosos por instalações portuárias e embarcados [14]. Para a Resolução CONAMA 237, e pela Instrução Normativa IBAMA número 5 de 2010, aplicam-se também requisitos da Lei Complementar número 140, já regulamentada em 8 de dezembro de 2011 que estabelece as regras sobre autorização ambiental para trânsito (aéreo, marítimo-fluvial, ferroviário, rodoviário) de produtos perigosos no território brasileiro $[15,16]$.

\subsubsection{Normas internacionais}

As organizações internacionais, através de acordos, editam normas para manipulação, transporte, armazenamento e o uso de fontes de radiação. Dos princípios previstos pelos órgãos regulamentadores o princípio da limitação de dose aos indivíduos ocupacionalmente expostos (IOE) e aos indivíduos do público são sempre acompanhados por valores que se relacionam aos estabelecidos pelas Normas IAEA, ICRP e parâmetros do NIST. A AIEA editou o estatuto que estabelece padrões de segurança e proteção contra a radiação ionizante que também dá providências sobre a utilização pacífica das atividades nuclear [17] e ainda elaborou o documento atualizado Safety Standard Series número TS-R-1 (ST-1, Revised), no ano de 2000, que regulamenta e define os requisitos para o transporte seguro de materiais radioativos [18].

O Comitê Internacional para Proteção Radiológica (International Commission on Radiological Protection ICRP) publicou o documento 103 que tem como escopo principal recomendações sobre proteção contra a radiação ionizante e os avanços para o benefício do público da ciência de proteção radiológica [19]. O Instituto Nacional de Padrões e Tecnologia (National Institute of Standards NIST) compila, elabora e publica banco de dados e tabelas frequêntemente atualizadas para referência do cálculo do coeficiente de atenuação e absorção de 
energia da radiação, em substâncias de interesse da dosimetria [20,21].

\subsubsection{Transporte de materiais radioativos}

Geralmente a localização da planta nuclear de produção de material radioativo pode não estar próximo ao centro de fracionamento, ou mesmo do local de uso dos radioisótopos. Na grande maioria dos casos, estes centros de produção e fracionamento estão localizados em áreas afastadas e separados por grandes distâncias, atendendo as questões de segurança e logística da distribuição. Por essa razão é necessário o seu transporte entre as instalações mencionadas.

Para que o transporte possa ser feito com segurança, e de forma apropriada, os materiais radioativos devem estar acondicionados em uma embalagem devidamente projetada e construída, de forma a funcionar como uma barreira efetiva entre a fonte radioativa e o meio ambiente. O conjunto completo de embalagem, material radioativo acondicionado e seu recipiente é chamado de embalado.

Existem normas internacionais já criadas com o objetivo de tornar 0 transporte mais seguro para pessoas, objetos e ao meio ambiente [8-10,12]. A Organização das Nações Unidas (ONU) em sua classificação internacional de produtos inclui os materiais radioativos como produtos perigosos Classe-7. O Safety Standard Series número TS-R-1 (ST-1, Revised) incluem normas internacionais que foram utilizadas e serviram como base para a edição das normas e regulamentos nacionais. A Comissão Nacional de Energia Nuclear (CNEN), em 1988, editou a Norma CNEN-NE-5.01 que regulamenta sobre a aplicação de embalados contendo material radioativo e que estes devem ser tratados com os mesmos cuidados adotados para os produtos perigosos. Sendo que a segurança depende, basicamente, do projeto do embalado e não dos procedimentos operacionais. A norma é estabelecer, com relação ao transporte de materiais radioativos, requisitos de radioproteção e segurança a fim de garantir um nível adequado de controle da eventual exposição de pessoas, bens e meio ambiente à radiação ionizante [8-10].

A norma trata com amplitude a matéria pertinente ao manuseio de substâncias radioativas e suas aplicações. Em relação ao transporte de materiais radioativos, são abordadas questões sobre especificações de projeto e 
dispositivos para transporte. A norma também estabelece requisitos de radioproteção e segurança, a fim de garantir um nível adequado de controle de eventual exposição de humanos bens e a natureza. $O$ transporte de materiais radioativos está regulamentado pela Resolução CNEN 013/88, publicado no Diário Oficial da União, em 01 de agosto de 1988. Segue logo abaixo, a transcrição de parte da norma que trata do controle sobre as fontes radioativas e a atividade do transporte, armazenamento e intervenções decorrentes do manuseio de substâncias caracterizadas como perigosas $[7,9,10]$.

\begin{abstract}
O limite indicado para transporte de material altamente radioativo, recomenda distância segura como raio de um metro de um dispositivo do modelo embalado, onde o limite de dose é de $2 \mathrm{mSv} / \mathrm{h}(200 \mathrm{mrem} / \mathrm{h})$ [8]. O limite derivado de taxa na parte externa de uma blindagem é de $0,025 \mathrm{mSv} / \mathrm{h}$ ou $2,5 \mathrm{rem} / \mathrm{h}$ ou 2,5 $\mathrm{mR} / \mathrm{h}$. Esse limite foi imposto para um trabalhador durante $2000 \mathrm{~h}$ por ano (40 h/semana durante 50 semanas de trabalho) e define as áreas às quais se podem permitir acesso aos trabalhadores sem restrições quando há monitoração individual [11, 22].
\end{abstract}

A fim de executar ações conjuntas da política nacional de meio ambiente relativas às licenças ambientais e aprovações das áreas de instalações de plantas nucleares e atividades transporte, a CNEN e o IBAMA firmaram em outubro de 2014, o Acordo de Cooperação Técnica. Este acordo inclui a Nota Técnica IBAMA-CNEN número 01-2013 que disciplina a aplicação dos regulamentos de transporte e oferece orientação para a elaboração do Plano Geral de Transporte $[15,16]$.

\title{
3.1.4 Normas de proteção radiológica
}

No âmbito nacional, as diretrizes de proteção radiológica estão regulamentadas pela Norma CNEN-NN-3.01. As diretrizes básicas sobre proteção radiológica, práticas e as intervenções que envolvem efeitos biológicos deletérios às pessoas advindos da exposição às fontes radioativas naturais ou manufaturadas, têm seus métodos de contenção de riscos tratados e são, ao nível da necessidade, compatibilizados com as normas internacionais ICRP e diretrizes IAEA [22,23].

Em decorrência da Norma CNEN-NN-3.01 qualquer desenvolvimento, projetos de equipamentos e serviços que implique em uso de fonte radioativa 
devem estar em conformidade com as disposições das normas da CNEN. Quando necessário adicionalmente, para que possam transitar internacionalmente, devem atender às normas emitidas pela Agência Internacional de Energia Atômica (AIEA) e também publicado pela Comissão Internacional de Unidades de Medidas da Radiação (International Commission on Radiation Units and Measurements - ICRP) [9,23].

A Norma CNEN-NN-3.01 e CNEN-NN-3.02 possuem requisitos complementares sobre radioproteção incluindo especificações aplicadas à fabricação de embalados que compatibilizam a regulamentação nacional aos documentos ICRP Publicação 103 e 118 apresentados tratam sobre a categorização dos indivíduos expostos a radiação e o tipo da dose limite [17-19].

Traz também as recomendações para os limites de dose efetiva de exposição máxima permitida à radiação, ou limite máximo recomendado ao trabalhador exposto (trabalhador exposto faz menção ao pessoal que exerce atividade próximo de fontes radioativas ficando ocupacionalmente exposto) e o público (faz menção ao indivíduo da população geral que não pertence à categoria de estar exposto à radiação por exercer atividades laboriosas necessariamente próximos de fontes radioativas) [23,24].

Para as mesmas categorias de exposição à radiação, público e ocupacional, também são especificados os limites de dose equivalente de máxima exposição para a pele, pés e mãos que é de 500 mSv/ano e para a lente do globo ocular (cristalino) de $20 \mathrm{mSv} / \mathrm{ano}$, sendo esse valor coincidente com o valor efetivo de dose. Na norma são feitas algumas ressalvas, como o fator redutor dos limites anuais para o indivíduo ocupacional, no caso mulheres declarando-se grávidas, a taxa anual não deve exceder $1 \mathrm{mSv} / \mathrm{ano}$. A taxa de dose de 1 mSv/ano também é indicada como limite anual para um período continuado, ininterrupto, de cinco (5) anos para exposição pública [17,18,24].

\subsection{Radiação}

O fenômeno físico da radiação é definido como uma forma de manifestação da energia e a sua propagação. A radiação vem sendo estudada pela física quântica e pode ser descrita como tendo simultaneamente características ondulatórias e de partícula. É sabido que a radiação tem essa natureza dual, isto é, tem o caráter de onda eletromagnética ou partícula e que deste modo foi 
descrito de pacote de energia com uma quantidade (quantum) discreta de energia denominado como fóton. A depender de sua interação com o meio estes fótons podem ser entendidos como partícula (corpuscular), ou onda (eletromagnética) $[25,26]$.

A radiação, também conhecida por energia radiante é emitida por uma fonte e se propaga de um ponto a outro, do espaço sob a forma de ondas eletromagnéticas, ou de partículas, com ou sem carga elétrica. Uma forma de caracterizar as ondas eletromagnéticas é pela energia $(h v)$ de seus fótons, ou ainda pelo comprimento, ou ainda pela frequência da onda eletromagnética. Quando a radiação interage com a matéria e tem energia suficiente para ao chocar com um átomo neutro, além de ejetar um de seus elétrons, obtém-se um átomo com carga positiva, diz-se que a radiação é ionizante. O termo radiação ionizante, ou simplesmente radiação, é usado para designar um feixe de partículas com ou sem carga elétrica, ou para as ondas eletromagnéticas propriamente ditas [26].

Todo o feixe de partículas sem carga e as ondas eletromagnéticas possuem certa probabilidade de atravessar a matéria, sem que ocorra choque com seus átomos. Isto é, sem sofrer nenhuma interação, portanto, não haverá atenuação da energia neste caso. Havendo interação do feixe de radiação com os átomos da matéria: a profundidade de penetração do feixe não está relacionada como função monotonicamente crescente, ou decrescente da energia da onda eletromagnética. A energia é depositada pelo caminho da onda passando a ocorrer excitação nos átomos [26, 27].

\subsubsection{Decaimento radioativo}

Os processos radioativos seguem uma lei de desintegração exponencial como ilustra a figura (FIG. 3.1). Se, inicialmente, o número de núcleos radioativos de um tipo é $\mathrm{N}_{0}$, o número de núcleos desse mesmo tipo, remanescentes, após um tempo t é dado por uma equação que segue a lei de Beer-Lambert mostrada na Eq. 1 [28]:

$$
\mathrm{N}_{(\mathrm{t})}=\mathrm{N}_{0} \mathrm{e}^{-\lambda \mathrm{t}}
$$

onde o tempo (t) é a constante de desintegração (ou constante de decaimento) e comprimento de onda $(\lambda)$ são características do núcleo em questão.

O intervalo de tempo $\mathrm{T}$, durante o qual metade dos núcleos radioativos de 
um tipo presentes na amostra decai, é chamado meia-vida. Por exemplo, uma amostra radioativa de $200 \mathrm{~g}$ de certo isótopo radioativo, com uma meia-vida de 10 dias, depois de 30 dias terá $25 \mathrm{~g}$ do isótopo original [28,29]. Agora, pela expressão acima, se obtém a Eq. 2:

$$
1 / 2 N_{0}=N_{0} e^{-\lambda T}
$$

de onde se tira que

$$
-\lambda T=0,6931 \text { e } T=t_{1} / 2 .
$$

Figura 3.1 Gráfico decaimento por processos radioativos seguem uma lei de desintegração exponencial [27].

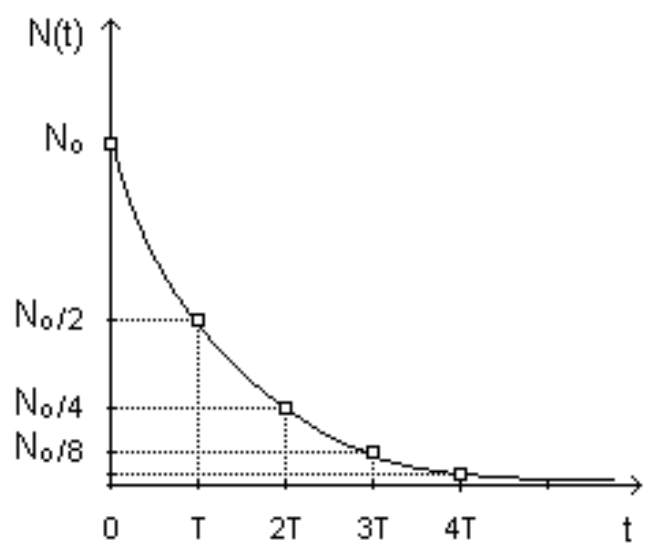

Fonte: radiação ultravioleta

Se $\mathrm{N}$ é o número de núcleos radioativos presente em algum instante do decaimento, então a taxa de mudança entre o número $(\mathrm{N})$ de núcleos presentes (decaimento) será como na Eq. 3:

$$
\frac{d N}{d t}=-\lambda N
$$

onde $\lambda$ é conhecido como constante de decaimento do núcleo $\left(\mathrm{s}^{-1}\right)$, e a probabilidade por unidade de tempo que um núcleo irá decair. O sinal negativo na equação indica que $\mathrm{dN} / \mathrm{dt}$ é negativo porque $\lambda$ e $\mathrm{N}$ são positivos, equivalendo dizer que $\mathrm{N}$ decresce com o tempo. A Eq. 4 também pode ser escrita como:

$$
\frac{d N}{N}=-\lambda d t
$$

podendo assim ser integrada (Eq. 5) resultando em:

$$
\int_{N_{0}}^{N} \frac{d N}{N}=-\lambda \int_{0}^{t} d t \Rightarrow \ln \left(\frac{d N}{N}\right)=-\lambda t
$$

Resultando na expressão do decaimento exponencial Eq. 6:

$$
N=N_{0} e^{-\lambda t}
$$


onde a constante $\mathrm{N}_{0}$ representa o número do núcleo radioativo no instante $\mathrm{t}=0$.

A taxa de decaimento $(R)$, ou número de decaimentos por unidade de tempo, pode ser obtido por diferenciação em relação ao tempo como segue na Eq. 7:

$$
R=\left\lceil\frac{d N}{d t}\right\rceil=N_{0} \lambda e^{-\lambda t}=R_{0} e^{-\lambda t}
$$

onde $R_{0}=N_{0} \lambda$ é a taxa de decaimento no instante $\mathrm{t}=0$ e $R=\lambda N$. A taxa de decaimento de um espécime é conhecida como sua atividade. Pode ser observado que tanto $\mathrm{N}$ como R decrescem exponencialmente com o tempo. Outro parâmetro muito usado na caracterização dos decaimentos radioativos nuclear é a meia-vida $\left(T_{1 / 2}\right)$, como já mencionado. Em outros termos, a meia-vida de uma substância radioativa pode ser também definida como o tempo decorrido para que a massa de núcleos radioativos passe a ser metade da inicial. Assim fazendo, pode ser calculado como $N=N_{0} / 2$ e $t=T_{1 / 2}$, resultando em $\frac{N_{0}}{2}=N_{0} e^{-\lambda T_{1 / 2}}$ e escrevendo $e^{-\lambda T_{1 / 2}}=2$ ao aplicar o log (In) em ambos os lados da equação obtêm a Eq. 8:

$$
T_{1 / 2}=\frac{\ln 2}{\lambda}=\frac{0,693}{\lambda}
$$

Esta é uma expressão mais conveniente para expressar a constante de decaimento de meia-vida, onde por definição $\left(N_{0} / 2\right)$ ainda resta metade dos núcleos radioativos originais. Após decorrer dois ciclos de meia-vida, outra metade dos núcleos radioativos remanescentes terá decaído, então restarão $N_{0} / 4$ núcleos radioativos, seguindo assim obtém $N_{0} / 2^{n}$ demonstrando que o decaimento nuclear é independente do tempo decorrido do espécime.

O tempo de meia-vida dos núcleos radioativos têm valores que vão desde frações de segundo, até um número muito grande de anos, e inclusive entre os isótopos de um mesmo elemento da tabela periódica. A Tabela 3.1 mostra o tipo de decaimento e a meia-vida dos isótopos do urânio. A fissão espontânea não é, estritamente falando, um processo de decaimento. De qualquer modo, na tabela assinala-se com um asterisco o número de massa dos isótopos que estão sujeitos a esse tipo de processo de decaimento [28,30].

Tabela 3.1 Decaimentos meia-vida dos isótopos do urânio por fissão espontânea [28].

\begin{tabular}{lll}
\hline & Tipo de & Meia vida \\
$\mathrm{U}$ & Decaimento & $\left(\mathrm{T}_{1 / 2}\right)$ \\
\hline
\end{tabular}




\begin{tabular}{lcl}
\hline 230 & $\alpha$ & 20,8 dias \\
\hline 231 & Captura K & 4,2 dias \\
\hline $232^{*}$ & $\alpha$ & 70 anos \\
\hline $233^{*}$ & $\alpha$ & $1,59 \times 10^{5}$ anos \\
\hline $234^{*}$ & $\alpha$ & $2,47 \times 10^{5}$ anos \\
\hline $235^{*}$ & $\alpha$ & $7,04 \times 10^{8}$ anos \\
\hline $236^{*}$ & $\alpha$ & $2,34 \times 10^{7}$ anos \\
\hline 237 & $\beta^{-}$ & 6,75 dias \\
\hline $238^{*}$ & $\alpha$ & $4,47 \times 10^{9}$ anos \\
\hline $238^{*}$ & $\alpha$ & $4,47 \times 10^{9}$ anos \\
\hline 240 & $\beta^{-}$ & 14,1 horas \\
\hline
\end{tabular}

Fonte: física quântica atômo

\subsubsection{Atividade}

No estudo da radioatividade, o número de desintegrações de núcleos radioativos de uma dada amostra por unidade de tempo chama-se atividade dessa amostra. Pela expressão matemática da lei do decaimento, segue-se que a atividade $A(t)$, no instante $t$, pode ser escrita como na Eq. 9:

$$
A(t)=[\Delta N(t) / \Delta t]_{\Delta t \rightarrow 0}=-\lambda N_{0}(t) e^{-\lambda t}=-\lambda N t
$$

A equação 9 expressa as desintegrações para um núcleo radioativo por unidade de tempo, e é proporcional a quantidade, em número, de tais núcleos presentes. Assim, a atividade propriamente dita está associada a determinada quantia de núcleos que decaem por unidade de tempo, em uma dada amostra do radionuclídeo e que essa redução ocorre na mesma proporção da meia-vida do número núcleos presentes. A atividade é expressa em Curie, onde $1 \mathrm{Ci}=3,7 \mathrm{x}$ $10^{10}$ Becquerel e $1 \mathrm{~Bq}=1$ decaimento $\mathrm{s}^{-1}$. As expressões apresentadas na Eq. 9 como $N(t)$ e $A(t)$ expressam leis estatísticas que são verdadeiras apenas quando o número de núcleos radioativos é muito grande [30,31].

Dado um único núcleo radioativo, não se pode determinar o instante de tempo em que ele decairá ,nem associar a ele uma determinada meia-vida. Mas, pode-se calcular, a partir de certas considerações teóricas, a probabilidade de decaimento por unidade de tempo desse único núcleo radioativo. A constante de decaimento $\lambda$ dá exatamente essa probabilidade [29, 31].

\subsubsection{Estabilidade e radioatividade nuclear}


O núcleo consiste em uma unidade com uma coleção de prótons e nêutrons. No núcleo, os prótons, ou seja as partículas com carga positiva, por estarem extremamente próximos, sofrem uma grande força eletrostática de repulsão de uns sobre os outros impondo uma força extrema de aumento no volume do núcleo. Entretanto, o núcleo permanece no modo estável devido à força nuclear forte. Esta é uma força atrativa também é extremamente forte, e atua em distâncias infinitesimais (aproximadamente $2 \mathrm{fm}$ ) como em todas as partículas nucleares.

Os prótons são atraídos entre si pela força de ação nuclear, ao mesmo tempo em que se repelem pela força eletrostática, ou força coulombiana. A força atrativa nuclear também atua entre pares de nêutrons e entre nêutrons e prótons [26-28]. Existem aproximadamente 260 núcleos estáveis e centenas de outros núcleos observados que não são estáveis. A condição de estabilidade, conhecida como linha de estabilidade, está relacionada com a limitada igualdade numérica entre prótons e nêutrons $(\mathrm{N}=\mathrm{Z})$.

Para átomos leves, a igualdade de nêutrons e prótons no núcleo é uma ocorrência geral o que confere aos átomos leves maior estabilidade. Estes números de $\mathrm{Z}$ e de $\mathrm{N}$ são chamados de números mágicos e são $\mathrm{Z}$ ou $\mathrm{N}=2,8,20$, $28,50,82,126$. Como exemplo tem o hélio com números de $Z$ e $N=2$, que é muito estável. A força forte de atração nuclear é um tipo diferente do que a força eletromagnética ou gravitacional e elas dominam as forças coulombianas de ação entre prótons dentro das distâncias nucleares por serem mais fortes do que as forças coulombianas. A força nuclear forte decresce muito rapidamente até zero quando a separação entre núcleons (partículas no núcleo atômico) excede alguns fem (fentometro ou $10^{-12} \mathrm{~m}$ ) [27,28].

Ao ser plotado um gráfico da energia de ligação cada núcleon, (Eb/A), em função do número de massa de vários átomos estáveis observa-se que em média a energia de ligação é de 8,0 MeV por núcleon (FIG. 3.2) [29].

Figura 3.2 Gráfico da energia de ligação por núcleon em função do número de massa para região de estabilidade nuclear [29]. 


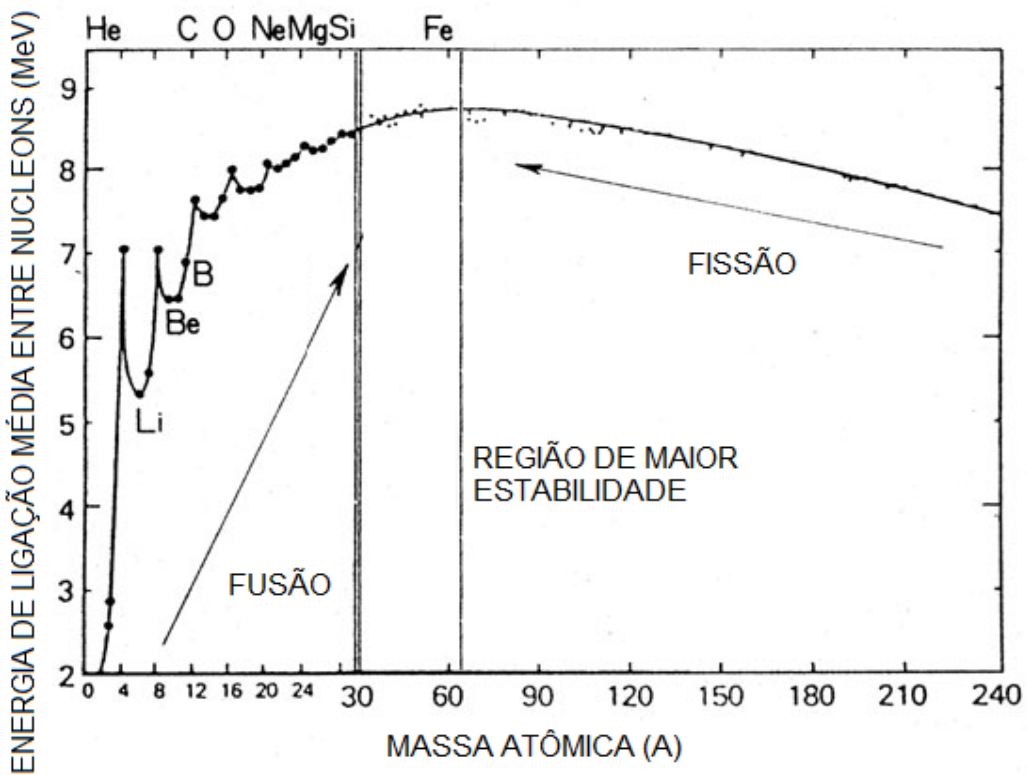

Fonte: Física Moderna

Decorrente da instabilidade nuclear nos fenômenos de fusão $(A \leq 20)$ e fissão (65 $\leq A \leq 200$ ) atômica, o saldo energético é ejetado como onda eletromagnética (fótons de alta energia), ou na forma de partículas com massa (partícula alfa, elétrons, pósitrons e etc.). Um pósitron é uma partícula parcialmente similar ao elétron, porém distinta pela natureza da carga que é contrária a do elétron $\left(\mathrm{e}^{-}\right)$, isto é, positiva $\left(\mathrm{e}^{+}\right)$. As três formas de radiação podem ser distinguidas por experimentos de natureza magnética que podem defletir o feixe de radiação de partículas carregadas, fazendo com que o feixe mude sua direção ou por não atuarem sobre um feixe de natureza ondulatória (fótons), não mudando sua trajetória. Estes tipos de radiação possuem diferente poder de penetração na matéria. As partículas alfa $(4 \mathrm{He})$ têm pouco poder de penetração podendo ser barrada por uma pequena espessura de massa, como exemplo de uma folha de papel. A partícula beta $\left(\beta^{+}, \beta^{-}\right)$tem maior poder de penetração, podendo penetrar alguns milímetros em uma fina placa de alumínio e os raios $X$, ou raios gama (fótons de alta energia) podem penetrar muitos centímetros no chumbo, até que possam ser efetivamente absorvidos [27].

Os mencionados processos de fissão do núcleo atômico e a ejeção de partículas ou ondas eletromagnéticas (fótons de alta energia) são geralmente denominados decaimento nuclear. A taxa de ocorrência de um decaimento em particular num espécime radioativo é proporcional ao número de radioatividade presente no núcleo (isto é, a quantidade total de nuclídeos que ainda não 
decaíram) [29].

A unidade do sistema internacional para o decaimento radioativo é o Curie (Ci), definida como sendo $3,7.10^{10}$ decaimentos $/ s \equiv 1 \mathrm{Ci}[25,28]$.

Um núcleo decai espontaneamente por três processos distintos que em alguns casos podem acontecer simultaneamente; decaimento alfa, decaimento beta e decaimento gama. Tem-se uma breve descrição dos decaimentos alfa e beta, e com maior aprofundamento o decaimento gama; de relevância para o entendimento da sua interação com a matéria e os fenômenos de decréscimo da energia radiante decorrentes do seu caminho, do transporte e atenuação por meio do meio material [26-28].

\subsubsection{Decaimento alfa}

Um núcleo emite partículas alfa ${ }_{2}^{4} \mathrm{He}$, perdendo dois prótons e dois neutrôns. Por consequência, o núcleo decresce seu número atômico $(Z)$ de 2 unidades, e a sua massa atômica (A) decresce de 4 unidades, ja o seu número de neutrôns decresce de 2 unidades. $O$ decaimento pode ser escrito na forma da Eq. 10:

$$
{ }_{Z}^{A} X \rightarrow{ }_{Z-2}^{A-4} Y+{ }_{2}^{4} H e
$$

onde $\mathrm{X}$ é dito núcleo-pai e $\mathrm{Y}$ é dito núcleo-filho.

\subsubsection{Decaimento beta}

Uma reação nuclear por um núcleo radioativo pode decair liberando partículas e ondas, se como resultado do decaimento o núcleo-filho mantém o número de núcleons como do núcleo-pai, mas o número atômico sofre alteração de uma unidade entende-se que a reação nuclear ocorreu por decaimento beta como nas Eqs.11 e 12.

$$
{ }_{Z}^{A} X \rightarrow{ }_{Z+1}^{A} Y+e^{-}+\bar{v}
$$

ou

$$
{ }_{Z}^{A} X \rightarrow{ }_{Z-1}^{A} Y+e^{+}+v
$$

Pode-se, novamente, observar que o número de núcleons e o total de cargas para ambos os lados da equação de reação se conservam, porém esta equação não retrata todo fenômeno da reação. Nas equações Eq.11 e Eq. 12 aparecem como terceira partícula, resultante da reação nuclear: os neutrinos $(v)$ e 
antineutrinos $(\bar{v})$, partículas que justificam os princípios de conservação de energia e do momento. Os neutrinos têm como propriedade ausência de carga elétrica, massa de repouso muito inferior a do elétron (inferior a 2,8 eV/c ${ }^{2}$ ), spin $1 / 2$ satisfaz a lei de conservação do momento angular aplicada ao decaimento beta, fraca interação com a matéria sendo muito difícil de ser detectado [29].

Pode ser observado na Eq. 13, a origem de partículas beta- $\beta^{-}$(elétron) e beta+ $\beta^{+}$(pósitron) na reação:

$$
{ }_{6}^{14} C \rightarrow{ }_{7}^{14} N+e^{-} \text {e }{ }_{7}^{14} N \rightarrow{ }_{6}^{12} C+e^{+}
$$

Da equação pode ser observado que a partícula beta tem sua origem no decaimento do nêutron para um próton, na primeira etapa da reação e de próton para nêutron, na segunda etapa da reação. Embora representado numa única equação, estas reações não estarão acontecendo como uma sucessão em dado intervalo de tempo [29]. A primeira etapa apresentada é conhecida como decaimento do carbono-14 que ocorre com 5.730 anos e é tipicamente conhecida por ser usada na datação de fósseis usando o cálculo de meia-vida $\left(T_{1 / 2}\right)$. $O$ potencial de penetração na matéria de partículas beta é de pequena probabilidade devido a fácil interação entre as cargas na espessura inicial do material $[28,30]$.

\subsubsection{Decaimento gama}

A radioatividade nuclear é resultante do decaimento nuclear, isto é, quando um núcleo radioativo, no estado de excitação, decai e não libera partículas e sim energia na forma eletromagnética (fóton). Este processo pode ser sucedido por sequências de outros processos de decaimento. O núcleo pode chegar ao estado de estabilidade, por emissão de um fóton de alta energia como na Eq. 14.

$$
{ }_{Z}^{A} X * \rightarrow{ }_{Z}^{A} X+\gamma
$$

onde $X *$ indica um núcleo no estado excitado.

A meia-vida $\left(T_{1 / 2}\right)$ de um núcleo excitado é de $10^{-10} \mathrm{~s}$. Os fótons emitidos pelo processo de desexcitação nuclear são denominados raios gama $[36,37]$. Alguns destes fótons têm muita energia que pode estar entre 1,0 MeV e 1,0 GeV. A energia de um fóton emitido, (ou absorvido), por um átomo é igual à diferença de energia nos dois estados eletrônicos envolvidos no processo. De modo análogo, um fóton de energia $(h v)$ é igual à diferença de energia $(\Delta E)$ entre os dois estados de energia nuclear. Quando um núcleo decai em energia por 
emissão de fóton gama pode ser observado que o núcleo não muda seu número atômico (Z) ou sua massa atômica (A). O núcleo pode alcançar um estado excitado em razão de um violento choque com outra partícula, isto também pode ocorrer com núcleos que sofreram decaimentos por emissão de partículas alfa e particulas beta.

O decaimento gama $(\gamma)$ é uma emissão de radiação eletromagnética com frequência muito elevada, na porção do espectro eletromagnético correspondente aos raios $\gamma$, causada por um rearranjo dos prótons em um núcleo. Pode acontecer, por exemplo, quando um núcleo sofre decaimento $(\alpha)$ ou $(\beta)$, deixando um núcleo-filho em estado excitado. Este, então, ao passar para o estado fundamental, emite radiação gama.

De modo geral, o núcleo-filho permanece no estado excitado, antes de emitir o fóton, por cerca de $10^{-12}$ segundos. Um fóton gama $(\gamma)$ tem massa (de repouso) nula e carga também nula, de modo que a emissão de um fóton gama $(\gamma)$ por um núcleo não tem efeito sobre o seu número atômico nem sobre o seu número de massa. Os fótons gama $(\gamma)$ emitidos têm energias entre $10^{3} \mathrm{eV}$ a 1 $\mathrm{MeV}$ e podem ser bloqueados por uma lâmina de chumbo com vários centímetros de espessura [26-29].

\subsection{Interação da radiação com a matéria}

Um material pode ser meio de transporte para a radiação corpuscular (partículas), ou eletromagnética (fótons), podendo sofrer diversos processos de interação em seu trajeto. A fissão nuclear que ocorre nos reatores só é possível de ser realisada porque são produzidas artificialmente interações de nêutrons, com o núcleo dos átomos de urânio que formam o meio material do combustível nuclear [31, 32].

\subsubsection{Interação de nêutrons}

Os nêutrons não possuem carga coulombiana, sendo assim não sofrem ação de forças coulombianas, quando estão atravessando um meio material e interagem muito fracamente com os elétrons, neste caso só restam as interações por processos de choque elástico e inelástico. Em geral os processos de interação que produzem indução das reações nucleares, por seção de choque 
dos neutrôns aumentam quando a energia dos nêutrons diminui tornando-os mais lentos. Os nêutrons livres sofrem decaimento beta com meia vida $\left(T_{1 / 2}\right)$ de 10 minutos [33-35]. Outro processo que pode ocorrer é a absorção do nêutron por um núcleo antes do seu decaimento. Quando um nêutron rápido (energia maior que 1,0 MeV) se move através de um meio material, ele irá sofrer eventos de espalhamento decorrentes das interações com os núcleos e em cada evento o núcleo irá transferir parte de sua energia cinética para os núcleos que interagiu. $O$ mesmo continuará a perder energia até que a quantidade de energia restante seja igual à energia térmica, ou $K_{b} T$, onde $K_{b}$ é a constante de Boltzmann e $T$ é a temperatura absoluta. Um nêutron com essa energia é denominado nêutron térmico e com essa energia, a captura do nêutron, por um núcleo tem sua probabilidade sensivelmente aumentada [36-40]

A seção de choque associada à captura de nêutron depende da natureza do elemento químico do núcleo alvo e da energia do neutrôn incidente. Para alguns materiais de núcleos maiores a seção de choque será pequena, e haverá probabilidade de predominância de choques elásticos. Materiais com estas características são chamados de moderadores porque eles atuam efetivamente como redutores da energia do nêutron incidente [41-45].

\subsubsection{Efeito fotoelétrico}

No processo de absorção por efeito fotoelétrico (FE), um fóton de raios $X$ produzidos artificialmente ou raios gama originados por decaimento de núcleos atômicos são totalmente absorvidos por um átomo. No seu lugar, um elétron do átomo é ejetado com grande velocidade, denominado fotoelétron. O efeito FE ocorre com o átomo como um todo, só não ocorre com elétrons livres em função da conservação de momento. Quando a interação de fóton da radiação ocorre com um elétron da camada mais interna do átomo resultando na absorção da radiação e na ejeção do elétron do átomo ocorre a ionização do átomo. Uma vez ionizado, o átomo deve retornar ao estado neutro de cargas com a emissão de raios $X$ característico do elemento no material [40]. Esta emissão subsequente de fótons é geralmente denominada de feixe secundário ou de baixa energia podendo, posteriormente, ser totalmente absorvida. A absorção fotoelétrica é o processo dominante na absorção de raios $X$ ou raios gama de energias entre $10^{\circ}$ $\mathrm{keV}$ e $10^{3} \mathrm{keV}$. A absorção pelo fenômeno fotoelétrico também é dominante para 
os átomos de maior densidade atômica ou de números atômicos mais altos $[41,47]$. A energia do fotoelétron $\left(E_{e}\right)$ é dada pela Eq. 15.

$$
E_{e}=h v-E_{b}
$$

Onde $E_{b}$, é a energia de ligação do elétron e $h v$ é a energia do fóton. Para raios gama com energia acima de algumas dezenas de $\mathrm{keV}$, o fotoelétron absorve e transporta a maioria da energia do fóton. Este efeito dá origem a um átomo ionizado no material absorvedor com uma vacância em uma das suas camadas da eletrosfera. Essa vacância será rapidamente preenchida por um elétron livre do meio e por reordenação irá neutralizar a carga do átomo resultando na emissão de um ou mais fótos de raios $X$. Estes raios $X$ serão, também, absorvidos pelo meio $[41,46]$.

\subsubsection{Efeito Compton}

O efeito Compton ou espalhamento Compton é o fenômeno que ocorre quando um fóton de raios $X$, ou raio gama de um feixe incidente é desviado de sua direção original por uma interação com um elétron do material absorvedor. $O$ espalhamento Compton é o efeito predominante na absorção de energias entre $10^{0} \mathrm{keV}$ e $10^{3} \mathrm{keV}$. No espalhamento Compton, o elétron, supostamente, em repouso do alvo absorve parcialmente a energia do fóton. O fóton é espalhado a um ângulo $\theta$ em relação a sua direção original de incidência no átomo. Em razão de que todas as direções de espalhamento são possíveis, a energia transferida pelo fóton ao elétron pode variar, podendo chegar a ser uma grande fração da energia inicial do fóton incidente. A Eq. 16 expressa a relação de energia e momento entre a energia transferida e o ângulo de espalhamento.

$$
p_{0}=p \cos \theta+p \cos \phi
$$

$\mathrm{O}$ fóton de raios $\mathrm{X}$, ou raios gama que perde parcialmente sua energia devido à interação, continua percorrendo o material ao longo de um novo caminho, alterado em função do choque. Uma vez que o fóton de raios $\mathrm{X}$ ou raios gama é desviado, eles acabam por ter menos energia, portanto um comprimento de onda $(\lambda)$ maior do que o fóton incidente. O efeito também é conhecido como espalhamento incoerente porque a mudança de energia do fóton resultante de uma interação nem sempre é ordenada e consistente. A mudança de energia é, então dependente do ângulo de espalhamento e não da natureza do meio da interação [28, 31,48]. 


\subsubsection{Efeito produção de pares}

A produção de pares ocorre como resultado da interação radiação-matéria, onde são criadas duas partículas de igual massa, um elétron (carga negativa) e um pósitron (carga positiva), resultando na aniquilação do fóton. A produção de pares tem possibilidade de ocorrer quando a energia do fóton for maior do que $1,02 \mathrm{MeV}$. Porém o efeito passa a ter maior probabilidade de ocorrência para as energias acima de 10,0 MeV [28-31,49]. Os pósitrons são de vida curta e desaparecem pelo efeito da aniquilação de pósitron com a formação de dois novos fótons de energia de $0,511 \mathrm{MeV}$. A produção de pares é de particular importância quando os fótons de alta energia passam por materiais de alto número atômico $[31,46]$.

\subsubsection{Espalhamento Thomson}

O espalhamento Thomson, também conhecido como dispersão de Rayleigh, é denominado coerente ou clássico quando existe a ocorrência da interação do fóton de raios $X$, ou de raios gama com o átomo como um todo (unidade). O núcleo e a eletrosfera atuam como uma unidade, de modo que o fóton é espalhado sem que ocorra mudança no estado de energia interna para o átomo atingido. No espalhamento Thomson dispersão ocorre praticamente sem a perda de energia radiante e ocorre principalmente de maneira retilínea. A dispersão por espalhamento Thomson é o fenômeno de menor contribuição para o coeficiente de absorção [29-31].

\subsubsection{Absorção eletrônica}

Outro fenômeno da radiação conhecido como absorção atômica é o processo pelo qual um fóton de raios $\mathrm{X}$ ou raios gama é capturado pelo núcleo de um átomo com a ocorrência da ejeção de uma partícula nuclear quando toda a energia dos raios $X$, ou raio gama é absorvido pelo núcleo [41]. Em certos casos os elétrons das camadas mais internas dos átomos podem se aproximar bastante do núcleo. Em particular, aqueles da camada $\mathrm{K}$, que é a mais interna. Um próton do núcleo pode capturar um desses elétrons e o processo se chama captura eletrônica. Se o elétron capturado estava na camada K, o processo é chamado captura $\mathrm{K}$. O resultado é a substituição de um próton do núcleo por um nêutron 
como expressa pela Eq. 17:

$$
{ }_{Z}^{A} X+e^{-} \rightarrow{ }_{Z-1}^{A} X+v \square
$$

podendo ser também representado pela Eq. 18:

$$
p+e^{-} \rightarrow n+v
$$

A captura eletrônica é seguida pela emissão de radiação eletromagnética (raios $\mathrm{X}$ ) pelo núcleo filho, resultante da passagem de um dos elétrons das camadas mais externas à lacuna da camada interior deixada pelo elétron capturado. O efeito da captura eletrônica é a mudança de um próton em um nêutron e, nesse sentido, o seu efeito sobre o núcleo é idêntico ao efeito produzido pela emissão [29-31].

\subsection{Seção de choque}

No estudo da atenuação da energia da radiação o principal fator a ser considerado é a seção de choque. Seu cálculo determina a absorção e espalhamento de fótons em um feixe paralelo, atravessando um filme superficial do meio material [38-40]. O estudo da probabilidade para a ocorrência destes processos é de considerável importância para o projeto de materiais de blindagens e para atenuação da radiação em equipamentos que utilizam fontes radioativas $[38,46]$.

O conceito de seção de choque está associado à descrição matemática dos parâmetros do processo de transporte e dos vários tipos e probabilidades de interação do meio material, como também da lei de espalhamento que faz previsão da mudança de energia e ângulo da partícula, ou fóton resultante do espalhamento [46-48]. A primeira descrição do conceito de seção de choque de um determinado material é a área efetiva do alvo $(\sigma)$ para a interação de uma partícula, ou fóton do feixe incidente. A seção de choque usa por unidade $\mathrm{cm}^{2}$ núcleo atômico, no caso das partículas incidentes serem nêutrons e $\mathrm{cm}^{2}$ elétron como no caso da interação ocorrer com fótons. A letra grega sigma ( $\sigma)$ é a referência para a secção de choque microscópica de um determinado elemento atômico (material) e é geralmente obtido através de ensaio experimental. Em teoria da radiação quando aplicada ao transporte de nêutrons, a unidade para seção de choque microscópica é o barns, onde a unidade do barns equivale a $10^{-}$ ${ }^{24} \mathrm{~cm}^{2}[41]$.

A seção de choque pelo efeito fotoelétrico, tem o valor dependente da 
energia do fóton e do alvo do meio material, átomo do elemento que faz o efetivo da absorção. Um conceito geométrico para seção de choque é um círculo centrado em cada átomo. Cada área ( $\sigma \mathrm{FE})$ de superfície laminar unitária se sobrepõe umas as outras e em paralelo ao plano desta área laminar unitária. Cada área laminar tem a propriedade de que todo o fóton que passe pela área destes planos paralelos possa ser absorvido pelo átomo por efeito fotoelétrico.

Para a seção de choque de outros fenômenos, as definições são semelhantes [46]. Os cálculos necessários são extraídos desta interpretação geométrica como modelagem do fenômeno. A figura 3.3 apresenta o gráfico da seção de choque para processo de espalhamento ( $\sigma E)$, fotoelétrica ( $\sigma \mathrm{FE})$, produção de pares ( $\sigma \mathrm{PR})$ e total $(\sigma)$ para um átomo de chumbo em função da atenuação versus energia do fóton hu $[49,50]$.

Figura 3.3 Gráfico dualog apresentando atenuação versus energia e probabilidades dos fenômenos envolvidos na seção de choque [49].

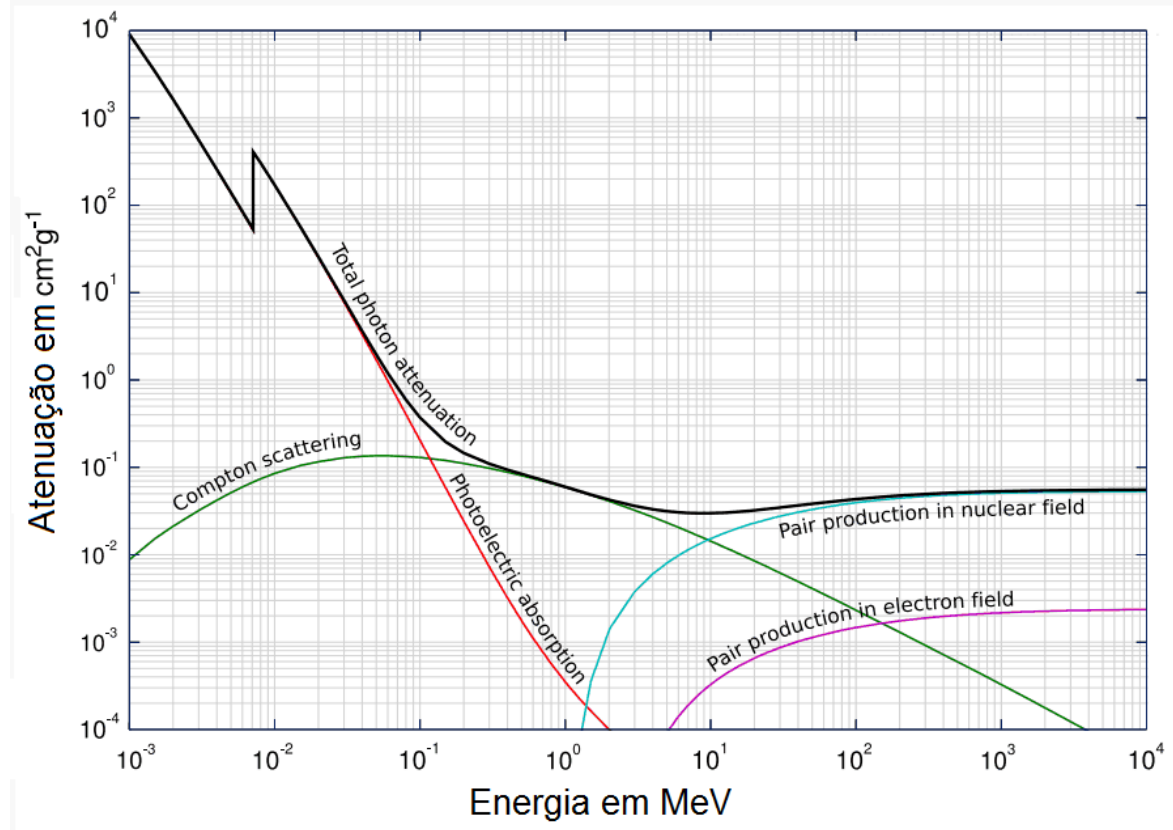

Fonte: Materiais e design

\subsection{Atenuação da radiação}

Quando a radiação interage com um meio material sua energia será dissipada ou absorvida mais rapidamente do que em seu trajeto livre. A interação das partículas alfa, beta e fótons podem ocorrer em razão de colisões com os átomos da matéria em sua trajetória. $\mathrm{Na}$ interação da radiação com a matéria pode ocorrer tipos diferentes de fenômenos. A absorção ou dispersão da energia de uma dada partícula, ou fóton que poderá ser total, ou parcial é denominada de 
atenuação da radiação. As outras partículas ou fótons do feixe, porém, podem transitar através do material, livremente sem interagir com nenhum átomo. $O$ número de fótons que pode ser transmitido através de um material depende da espessura, densidade, número atômico do elemento presente no material e da energia de cada um dos fótons no feixe. Mesmo quando todos os fótons do feixe têm a mesma energia, e a probabilidade de fazer diferentes caminhos, diferentes distâncias, através do material.

A probabilidade de ocorrer choque com um átomo aumenta em função da distância percorrida. Esta função define que em um ponto específico da matéria, o número de fótons diminui exponencialmente com a distância percorrida dentro do material. Para cálculo da espessura de blindagem um parâmetro importante de projeto é o valor máximo de energia do fóton da radiação $[39,41,50]$.

Uma vez que as características de atenuação dos materiais são importantes no desenvolvimento dos elementos de blindagem contra a radiação, a compreensão da relação entre a espessura do material, as propriedades de absorção e a energia do fóton é fundamental para a produção de uma blindagem eficiente, segura e de qualidade. A maior densidade atômica de um material proporcionará maior probabilidade de atenuação ou absorção que de uma dada energia radiante [31,32].

Uma maior intensidade do feixe de raios $X$, ou raios gama indica um maior número de fótons no feixe, contudo não muda a energia (hv) dos fótons feixe. Um fóton de raios $X$, ou raios gama pode perder toda ou quase toda a sua energia em uma única interação e a distância que ele percorre antes dele interagir não pode ser prevista, porém à distância na qual ele tem $50 \%$ de chance de interagir pode ser estimada [37].

O valor da camada semi redutora (half value layer - HVL) é bastante utilizado como referência na área de radioproteção. A distância percorrida pelo feixe de fótons em qualquer espessura de material na qual ele perde $50 \%$ da intensidade inicial, chama-se camada semiredutora. Um valor de espessura de um dado material equivale a uma camada semiredutora se este valor de espessura reduz pela metade $\left(I_{0} / 2\right)$ a intensidade da radiação eletromagnética inicial que atravessa esse material. De outro modo é equivalente dizer que a intensidade da radiação diminui para a metade do valor inicialmente medido a cada vez que atravessa uma unidade de espessura correspondente à de uma 
camada semi redutora no meio material específico [15, 26,47].

O modo como ocorre este processo de interação da radiação com a matéria e a sua atenuação é sempre igual e segue um comportamento que é também descrito sobre a forma de uma equação que recebe o nome lei de BeerLambert [26,28] apresentada na Eq. 17:

$$
d I_{(x)}=-I_{0(x)} \cdot n \cdot \sigma \cdot d x
$$

onde;

$\boldsymbol{d} \boldsymbol{I}=$ A intensidade atenuada

$I_{\mathbf{0}}=A$ intensidade inicial

$\boldsymbol{n}=$ A quantidade de átomos. $\mathrm{cm}^{-3}$

$\boldsymbol{\sigma}=A$ constante da seção de choque

$\boldsymbol{d} \boldsymbol{x}=$ A espessura incremental de camada do material absorvedor

Deste modo, quando a Eq. 17, é integrada ela passa a ser escrita na forma da Eq. 18:

$$
I_{(x)}=I_{0} e^{-n \sigma x}
$$

Após considerar que o fator $(\boldsymbol{n})$ volume de átomos no material, (átomos. $\mathrm{cm}^{-3}$ ) e a constante de proporcionalidade $(\sigma)$, da Eq. 18 podem ser multiplicados resultando no coeficiente de atenuação do material $(\boldsymbol{\mu})$, usualmente a equação passa a ser escrita na forma da Eq. 19:

$$
I_{(x)}=I_{0} e^{-\mu x}
$$

onde;

$\boldsymbol{I}_{(\boldsymbol{x})}=A$ intensidade transmitida

$\mathbf{I}_{\mathbf{0}}=A$ intensidade inicial dos fótons

$\boldsymbol{\mu}=O$ coeficiente linear de atenuação do material

$\boldsymbol{x}=$ A espessura do material absorvedor

O coeficiente linear de atenuação $(\boldsymbol{\mu})$ do material expressa, em termos de espessura de material, a fração do feixe de radiação gama ou raios $X$ que foi desviada com perda parcial de energia, ou absorvida pelo meio material atenuador [38]. Assim sendo o coeficiente linear de atenuação é basicamente a probabilidade que os elétrons, ou núcleo destes átomos em um dado volume de material possam interagir com o fóton do feixe provocando sua atenuação total, ou parcial, ou choque com respectivo desvio de direção, com consequente perda de energia radiante em função de um determinado volume de material absorvedor 
[44].

Diversos materiais já possuem seus coeficientes de atenuação linear determinados, tabelas e gráficos dos coeficientes para todos os elementos $Z=1$ a 92 vêm sendo disponibilizados por diversos laboratórios, incluindo a própria base de dados do Instituto Nacional de Padrões e Tecnologia - NIST [33]. Entretanto, para compostos e misturas de interesse muitas vezes é mais fácil localizar dados de atenuação em termos do coeficiente de atenuação massivo. As tabelas no site do NIST cobrem as energias dos fótons de raios $X$, raios gama e efeito freamento (bremsstrahlung) de 1,0 keV para 20,0 MeV. A conversão de coeficiente de atenuação de massa pode ser calculada como coeficiente de atenuação linear considerando que o coeficiente de atenuação linear depende da densidade do material absorvedor [30,31].

\subsection{Medicina nuclear}

A medicina usa da tecnologia nuclear aplicada a geração de imagens e procedimentos terapêuticos especializados. No diagnóstico por imagens, materiais de natureza radioativa, em pequenas quantidades ou doses, são utilizados para determinar a severidade de diversas doenças bem como o eventual tratamento delas incluindo vários de tipos de câncer, doenças do coração, neurológicas, gastrointestinais entre outras. O uso de procedimentos em medicina nuclear possibilita identificar atividade a nível molecular, nos tecidos e órgãos do corpo humano sendo potencial auxilio para identificar doenças em seus estágios iniciais e também permitir intervenções terapêuticas com resposta imediata do paciente [51-53, 57].

Por emissão radioativa os radio-traçadores irão imprimir um sinal numa câmera especial, excitar detectores cintilográficos ou outro dispositivo de imagem que irá reconstruir a informação como imagem molecular do tecido [51,52].

No tratamento residual de doenças ou pequenas metástases são usados diversos radionuclídeos, como o lutécio-177 que emitem radiação beta de baixa energia ou partículas alfa $\left(\mathrm{T}_{1 / 2}=6,73\right.$ dias, $\mathrm{E}_{\beta \max }=497 \mathrm{keV}, 6,4 \%-\mathrm{E} \gamma=113 \mathrm{keV}$, $\left.11 \%-\mathrm{EY}_{\mathrm{Y}}=208 \mathrm{keV}\right)$. O uso de outros radiofármacos para o tratamento de doenças renais quando não é possível a utilização do lutécio-177, inclui a aplicação e o uso de moléculas de afinidade cromatográfica que operam como agentes direcionadores, permitindo erradicar pequenas metástases ou células 
tumorais únicas com a retenção dos radiomarcadores, como bismuto-212, bismuto-213 ou tório 227 [50, 52].

Em física médica o termo radionuclídeo refere-se somente aos átomos radioativos. Quando um radionuclídeo é combinado com uma molécula química que irá ter como função conferir localizações desejadas, essa combinação é denominada radioquímico. Já o termo radiofármaco é reservado para materiais radioativos que cumprem determinadas exigências legais para serem administrados aos pacientes, ou empregados em objetos específicos $[54,55,58]$.

\subsubsection{Molibdênio-99}

O molibdênio ( ${ }^{\mathrm{x}} \mathrm{Mo}$ ) possui 35 nuclídeos conhecidos e dentre eles há a ocorrência natural de somente sete com as seguintes massas atômicas: 92, 94, 95, 96, 97, 98 e 100. Deste, o único que apresenta forma instável é o ${ }^{100} \mathrm{Mo}$, que possui tempo de meia-vida $\left(\mathrm{T}_{1 / 2}\right)$ de $8,0 \times 10^{18}$ anos. $\mathrm{O}{ }^{100} \mathrm{Mo}$ tem $9,6 \%$ de ocorrência na natureza e seu decaimento do ${ }^{100}$ Mo para o ${ }^{100} \mathrm{Ru}$ ocorre com a emissão de duas partículas $\beta$. O nuclídeo natural de maior abundância é o ${ }^{98} \mathrm{Mo}$ com abundância de $24,1 \%$ [50].

O princípio básico na obtenção dos produtos radioativos é a fissão do núcleo de átomos pesados. A principal via de obtenção do Mo-99 é por fissão nuclear do urânio $\left({ }^{235} \mathrm{U}\right)$ em reatores nucleares. Inicialmente são produzidos os alvos de urânio de baixo enriquecimento (LEU). Uma parte deste subproduto de fissão dos alvos de urânio irradiados é o molibdênio-99 e seus isótopos. Após a extração o Mo-99 precisa ser transportado por equipamentos especiais que devem oferecer segurança, eficiência e rapidez de entrega na unidade onde exista uma célula quente. A rápida disponibilidade ao centro de fracionamento e distribuição aos centros de consumo do Mo-99m está relacionada à função da meia vida dos isótopos pai e filho $\left({ }^{99} \mathrm{Mo} \Rightarrow{ }^{99 \mathrm{~m}} \mathrm{Tc}\right)$. O nuclídeo ${ }^{99} \mathrm{Mo}$ é obtido artificialmente através da irradiação de alvos contendo ${ }^{98} \mathrm{Mo}$ ou ${ }^{100} \mathrm{Mo}$ e também por meio da fissão nuclear do ${ }^{235} \mathrm{U}$ em reatores nucleares [52].

Atualmente todos os radionuclídeos de uso clínico são produzidos em reatores nucleares, ou aceleradores cíclotrons. Os radionuclídeos de ocorrência natural tem meiavida longa, são caracterizados como de radiação pesada com alta toxidade; nestes incluem-se o urânio, tório, radio, radônio e actínio. Eles não têm aplicação clínica na medicina nuclear como agente de diagnóstico $[50,56]$. 


\subsubsection{Tecnécio-99}

O radiofármaco tecnécio-99 metaestável (Tc-99m) é resultado do decaimento do molibdênio-99 com meia-vida de 6,6 horas. Em função do alto valor agregado diz-se que ele perde $50 \%$ do seu potencial terapêutico neste intervalo de tempo, consequêntemente, transporte tem alto custo. A atividade específica do tecnécio-99m é suficientemente alta, porém associada ao seu tempo de meiavida razoavelmente baixo faz deste radiofármaco o elemento mais apropriado para diagnósticos em razão do custo-benefício clínico. O tecnécio-99 é o mais popular radiomarcador (radiolabel) porque agrega todas as propriedades determinadas que um radiofármaco deve ter. O potencial terapêutico do Tc-99m está na energia liberada pelo decaimento gama do seu estado metaestável para o Tc-99 mais estável [50-52]. Nesta transição cada átomo emite, com maior ou menor probabilidade de ocorrência, partículas $\beta^{-}$e fótons gama $(\gamma)$, em diversas energias, sendo o fóton de $140 \mathrm{keV}$, com ocorrência de $89 \%$ e o fóton de 740 $\mathrm{MeV}$, com ocorrência de $0,04 \%$, o mais energético [50,57].

\subsection{Metalurgia do pó}

A técnica de metalurgia do pó (powder metallurgy - PM) remonta de 3.000 AC e foi usada em diversas partes do mundo na produção de joias e outros utensílios. Os egípcios e incas usavam pó de ouro para a fabricação de joias. Mais recentemente, durante os anos do século XVIII, o uso de técnicas da metalurgia do pó começou a experimentar significativos avanços decorrente do desenvolvimento da química. Motivado pela necessidade de trabalhar com a platina para uso em aparelhos de seus laboratório, ambos os países, Rússia e Inglaterra, por via química, obtiveram pós precipitados. Utilizando processos de sinterização evitaram a necessidade de fundição em altas temperaturas [59,61].

A aplicação de novos método trouxe grande desenvolvimento para a técnica de metalurgia do pó. A necessidade de um material substituto para o carbono e o tântalo na fabricação de filamentos de lâmpadas, levou Coolidge a desenvolver um método de fabricação usando o pó de tungstênio que garantiu sua primeira patente, em 1909 [65].

Nas mais recentes aplicações da tecnologia de metalurgia do pó estão os compósitos de carbono com matrizes metálicas (metal matrix composites - MMCs) 
em que geralmente o metal matriz é mais dúctil. A partir da década de 1940, a tecnologia de metalurgia do pó permitiu o desenvolvimento de novos materiais por uso dos metais refratários ( $\mathrm{Nb}, \mathrm{W}, \mathrm{Mo}, \mathrm{Ti}, \mathrm{Zr}$ e $\mathrm{Re}$ ) e suas ligas. Metais difíceis de serem conformados por outros processos como fundição, forjamento ou que necessitem de usinagem, caso dos metais refratários, podem ser trabalhados por metalurgia do pó e oferecer econômica por ser um processo quase acabado near net shape [62,63].

Adicionalmente, os metais estruturais alcançaram grande desenvolvimento neste mesmo período. Em sua grande maioria metais estruturais usam pó de ferro na produção de componentes. O processamento de novos materiais compósitos na tecnologia MP passaram a ser utilizado nas aplicações da indústria nuclear, aeroespacial, eletro-eletrônica e magnética [60].

O método de produção, por metalurgia do pó, usualmente escolhido representa um compromisso entre considerações técnicas e econômicas. Para a correta seleção, do método de produção, por metalurgia do pó é necessário manter como objetivo as considerações sobre as características do pó-metálico e propriedades finais desejadas para a peça sinterizada $[64,66]$.

A caracterização do pó-metálico, entretanto, é provavelmente a etapa mais significativa. O tamanho da partícula, sua forma e possíveis alterações na pureza da matéria prima tem importante impacto no produto final. O tamanho e a forma das partículas de um pó podem elevar a dificuldade em alcançar boa densificação, em função das forças de fricção interpartículas que podem variar, crescendo muito, devido à irregularidade da forma. A maior superfície, sua rugosidade, e a forma causam menor densidade de empacotamento, alto ângulo de repouso e baixa taxa de escoamento do pó $[67,68]$.

Uma partícula é entendida como a menor unidade de um pó e assim sendo não pode ser dividida. Geralmente, a metalurgia do pó opera com partículas que são maiores do que partículas de fumaça $(0,01 \mu \mathrm{m}$ a $1 \mu \mathrm{m})$, porém menores do que partículas de areia $(0,1 \mu \mathrm{m}$ a $3 \mathrm{~mm})[69,71]$. O resultado final da produção no processo de metalurgia do pó está intrinsecamente condicionado as boas características dos pós usados na composição [70].

Muitos particulados de metal são similares àa medida do diâmetro de um cabelo humano (25 $\mu \mathrm{m}$ a $200 \mu \mathrm{m})$. Dentre as ferramentas e métodos disponíveis para caracterizar as partículas de um pó metálico, as micrografias obtidas com o 
uso do microscópio eletrônico de varredura - MEV são as que trazem maiores informações. As micrografias auxiliam identificar qualitativamente uma de características da partícula, tais como: de esfericidade regular até irregular, modo de achatamento para partículas de tamanho submicrom até $1 \mathrm{~mm}$, dentre outras séries de características [72-74].

Na maioria dos casos um fator desejado na técnica da metalurgia do pó é alcançar a maior densidade do produto acabado. Eventualmente é desejada a possibilidade de controlar a porosidade do material, de modo a produzir poros no sinterizado para elementos lubrificantes. Uma melhor densificação pode ser alcançada, por meio da caracterização e seleção do pó adequado (tamanho e forma das partículas); emprego de técnicas de prensagem no arranjo das formas do componente desejado (compactação); adequação do método de compactação $[68,73,75]$.

\subsubsection{Obtenção de pós-metálicos}

As propriedades físico-química dos particulados metálicos estão intrinsecamente ligadas ao processo de obtenção dos pós. Os pós-metálicos podem ser obtidos por diversas vias de produção. Os pós-metálicos são tipicamente obtidos através de atomização a água ou gás, centrifugação, por processo de eletródo giratório com plasma (plasma rotate electrode process $P R E P)$ e processos de redução química, dentre outros. Os pós atomizados a gás são vistos como as matérias-primas mais utilizadas para a fabricação de peças metálicas, em razão da facilidade de produção e qualidade final [65.72]. Em PREP, uma barra rotativa de matéria-prima é aquecida à alta temperatura, produzida por plasma de gás e o metal fundido é atomizado por centrifugação à medida que é jogado fora da barra. As gotículas de metal fundido vão sendo esfriadas em partículas de pó esféricas [73,76]. No processo de obtenção por via química, os pós são obtidos por reação de decomposição de um metal, no estado sólido por um meio gasoso. A redução de óxidos (decomposição de sólido por gás) por atmosfera redutora é o método mais comum de obtenção de pós [71, 72].

Outro processo para a produção de pós é o eletrolítico. O processo pode ser basicamente descrito por ser produzido por precipitação, dentro de uma célula eletrolítica. Cobre, titânio, berílio, ferro, paládio são alguns dos metais que podem ter pós produzidos por esse processo. O pó formado pelo processo eletrolítico é 
normalmente dendrítico para obtenção de pós. Essa via só permite a obtenção de pós elementares e a contaminação são fatores adversos do processo [75].

\subsubsection{Propriedades dos pós-metálicos}

Determinar as propriedades de pós utilizados para a obtenção de componentes e partes a base de metal, bem como as propriedades resultante do material metálico a granel, é condição necessária para que a indústria possa selecionar um pó com confiança e produzir peças e componentes consistentes com propriedades conhecidas e previsíveis Os padrões American Society for Testing and Materials (ASTM) estão baseados em pesquisas sobre de técnicas de caracterização. Os relatórios de procedimentos estão organizados nas propriedades mais importantes dos pós-metálicos, que são tamanho, morfologia, composição química, escoabilidade, propriedades térmicas e densidade $[77,78]$. Os métodos de teste para estas propriedades são descritas em várias publicações especializadas dos padrões ASTM e estão resumidos em outras bibliotecas [78,79]. Métodos de amostragem, que são importantes para garantir que as medidas de pequenas amostras de pó sejam representativas do lote inteiro, também estão cobertas [80,81].

\subsubsection{Escoabilidade e empacotamento}

Schwarzkopf [72] descreve sobre o fator de fluxo definindo que ele é o o tempo necessário para que um certo volume de pó possa fluir, atravessando o orifício de um compartimento de armazenamento do tipo funil e que ambos, compartimento e orifício devem começar e finalizar com a mesma forma geométrica e distribuição de modo a reduzir o coeficiente de atrito e sem componente magnética que possa afetar o fluxo. O tempo de taxa do fluxo é medido em unidade de tempo (segundos ou minutos) com um volume requerido de material (pó-metálico). A taxa pela qual o pó irá fluir por um orifício, de determinado diâmetro, por ação da força da gravidade é de grande importância técnica porque o rápido preenchimento da cavidade com maior massa de pó irá resultar em compactados na cor verde de maior consistência. O tempo que decorre para $50 \mathrm{~g}$ de uma amostra do pó atravessar o orificio de um funil (Hall) e ser depositado em um vaso é a medida do escoamento que é expressa em segundos ou em gramas por segundos $\left(\mathrm{g} \cdot \mathrm{s}^{-1}\right)$. 
German e Dowson [69, 71], em suas publicações, fazem considerações sobre as propriedades de escoabilidade e empacotamento das partículas, relacionando com o tamanho médio e suas formas ressaltando que a maior irregularidade encontrada pode interferir na taxa de empacotamento, na compactação e densidade do produto acabado. A forma mais usual para expressar a densidade aparente é a massa de um pó em gramas por centímetros cúbicos de um volume de pó descarregado sob ação da gravidade em um recipiente graduado de volume específico. Em outro ensaio, o recipiente é instalado em um equipamento de vibração padrão e seu volume é acomodado como batido (tapped density), certamente com redução do volume e aumentando a densidade em relação a densidade aparente. O fator de escoabilidade é importante para a etapa da compactação é o fácil preenchimento da cavidade da matriz pelo pó e redução de porosidade anterior a prensagem de fato. A relação entre densidade aparente e densidade batida (acomodação por vibração) é função da distribuição do tamanho de partícula no pó e da regularidade de forma sendo possível estabelecer a taxa de compressividade do pó.

A escoabilidade de um pó de metal afeta o comportamento na etapa de compactação. A umidade contida, a norfologia e distribuição do tamanho de partícula no pó, entre outros parâmetros, irão influenciar no escoamento. Qualquer mudança no comportamento de escoamento de um pó afeta o empacotamento na fase de compactação com consequências sobre as propriedades mecânicas no produto final. Se ocorrer desvios ou irregularidades no comportamento do fluxo de um pó durante o teste de escoamento é muito provável que existirá falhas no produto acabado [61, 63].

\subsubsection{Mistura e moagem dos pós}

A mistura é uma etapa pré-compactação na qual se busca promover a dispersão dos pós de diferentes espécies químicas. Procura-se introduzir alguma espécie de substância lubrificante; formar vários tipos de ligas; adicionar um elemento facilitador dos ligante, ou utilizar estas ações em conjunto para atingir resultados diversos [63]

Hirschho e German $[66,68]$ investigaram métodos para misturar pós e seus resultados demonstraram que ao preparar uma mistura é recomendável adicionar lubrificantes, para reduzir a ocorrência de fissuras e trincas e possibilitar o 
aumento da densificação do compactado. A etapa de mistura é necessária para preparar distribuições únicas de tamanho de partícula, combinar pós-metálicos diversos para gerar novas ligas durante a sinterização.

A prática da técnica de mistura é uma das razões porque promove melhor homogeinização na distribuição das partículas, bem como a redução de aglomerados na mistura de pós em função da redução da segregação de partículas tipicamente induzida durante o manuseio e transporte dos pós. A segregação é um efeito intrínseco dos pós baseado no tamanho, em que as partículas maiores permanecem no topo do volume, e esse efeito de segregação influência nas etapas de compactação e sinterização resultando na formação de aglomerados e o aumento de poros [69].

Costa e Neves [62,63] investigaram, o uso de moinho de esferas e moinho de alta energia (MAE) na redução do tamanho de partículas e aumento da densificação nos compactados a verde em razão da maior homogeneização e redução da relativa de tamanho de partículas na mistura resultando em uma estrutura mais heterogênea. O uso da técnica de moagem de alta energia, geralmente durante longos tempos de moagem, pode auxiliar no processo de redução de tamanho de partículas para formar pós compósitos mais homogêneos [62].

Costa [62] estudou os efeitos do uso de moagem por períodos de $8 \mathrm{~h}, 16 \mathrm{~h}$ e $24 \mathrm{~h}$, extendendo até $118 \mathrm{~h}$ na formação de solução sólida de pós do sistema tungstênio-níquel-cobalto, para promover a formação de melhor distribuição das partículas na mistura e como resultado obteve uma ganho na homogeinização da mistura com consequente redução das partículas no pó de tungstênio. Em outro estudo utilizando diferente composição para o sistema W-Ni-Co.

Chen e Hsun $[117,118]$ investigaram os efeitos secundários da moagem na preparação dos pós e resultou em refino dos particulados de tungstênio, facilitando o processo de sinterização com fase líquida e com a observação, de alargamento e redução, na intensidade nos picos do espectro da difração de raios $X$ puderam inferir sobre o crescimento de grãos, por mudanças nos parâmetros cristalinos.

\subsubsection{Obtenção da liga $\mathrm{Cu}-\mathrm{Ni}$}


As ligas $\mathrm{Cu}-\mathrm{Ni}$ são muito utilizadas e estão presentes em diversas aplicações devido suas características específicas. As propriedades físicoquímicas entre o cobre e o níquel são muito semelhantes [92,93]. As ligas Cu-Ni cristalizam em todo intervalo de concentração por uma rede cristalina cúbica de face centrada (CFC). Sobre as ligas de cobre é necessário distinguir entre ligas forjadas, aquelas processadas para produtos semiacabados, fundidas que são aquelas produzidas por vários processos de fundição $[68,91]$. $O$ diagrama de fase do sistema Cu-Ni foi estabelecido por Gurtler e Tammann e posteriormente melhorado por Pilling e Kihlgren. As ligas dos dois metais formam uma série contínua de soluções sólidas, perfazendo uma rede cristalina CFC, isto é, o sistema Cu-Ni mostra ter solubilidade completa nos estados líquido e sólido [93]. Os pontos de fusão dos dois componentes se ampliam para uma faixa de fusão nas ligas. A fase "liquidus" é demarcada pela área acima da curva superior, que forma o limite inferior da massa fundida líquida. A fase de formação dos cristais "alfa+liquidus" é formada pela área interna nos limites das curvas inferior e superior. A fase de solução sólida, estável da liga, está delimitada abaixo dos pontos de fusão dos dois componentes e no limite da curva inferior [94].

$\mathrm{Na}$ figura 3.4, a linha reta pontilhada no canto inferior direito, mostra que o comportamento é ferromagnético, acima é paramagnético. Assim, por exemplo, todas as ligas até $80 \%$ de $\mathrm{Ni}$ (\% em massa) são paramagnéticas a $150{ }^{\circ} \mathrm{C}$, enquanto que a $20{ }^{\circ} \mathrm{C}$ as ligas contendo mais de $68,5 \%$ de níquel exibem comportamento ferromagnético [88, 95]. Abaixo de uma linha reta pontilhada, no canto inferior direito, o comportamento é ferromagnético, acima é paramagnético. Assim, por exemplo, todas as ligas até $80 \%$ de Ni são paramagnéticas a $150^{\circ} \mathrm{C}$.

Figura 3.4 Diagrama de fase representativo da liga metálica do sistema Cu-Ni apresentando de relação percentual em massa com as mudanças em propriedades decorrentes da temperatura [69]. 


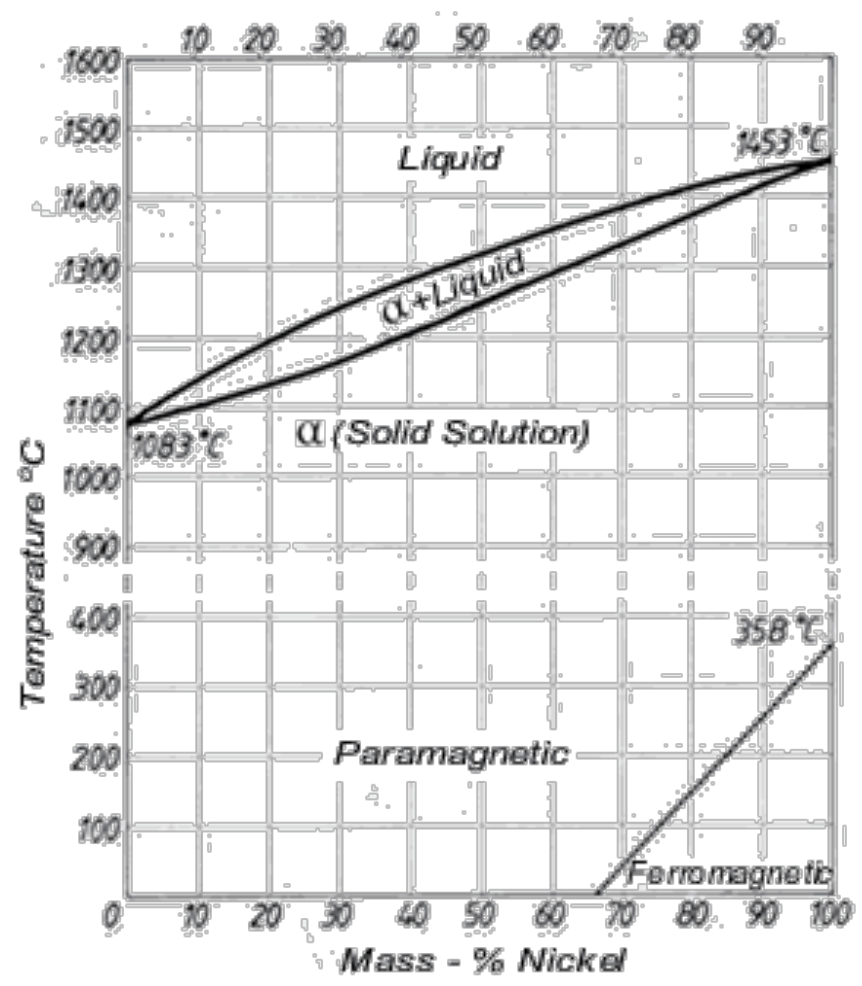

Fonte: Metal Powder Industries Federation

$\mathrm{O}$ níquel tem efeito significante nas propriedades físicas e mecânicas das ligas de $\mathrm{Cu}-\mathrm{Ni}$, aumentando a resistência mecânica. A resistência à corrosão aumenta em razão do teor de níquel e ocorre a redução da condutividade térmica e elétrica. A resistência à tração e ao alongamento melhora em função do teor de níquel na liga. A resistência à força de tração aumenta com o teor de níquel, o alongamento permanece quase constante após uma pequena diminuição, em teor de até $5 \%$ de Ni $[69,111]$.

\subsubsection{Compactação}

O processo de compactação envolve o rearranjo das partículas na matriz ocorrendo pelo escoamento, deformação elástica e plástica do pó, durante a etapa de prensagem $[69,72]$. O rearranjo decorre também do estado global de fragmentação normal e por cisalhamento que influenciam no resultado de uma maior densificação do compactado e consequente resistência mecânica [70,74].

Inicialmente pode-se separar os estados de fragmentação relacionada com os modos de compactação unidirecional, isostático e triaxial. A resposta em 
densidade e gradiente de densidade, quando comparada a resposta de densidade/resistência para unidirecional, isostática e método triaxial de compactação em uma variedade de pós são identificadas por rupturas na direção transversa a de resistência [75].

German [68-70] resume o processo de compactação em cinco estágios, como é apresentado na figura FIG. 3.14, fazendo distinção na deformação plástica em que difere o comportamento dúctil e frágil.

Figura 3.5 Diagrama esquemático apresentando por German propondo os cinco estágios possíveis de ocorrerem durante o processo de compactação [70]

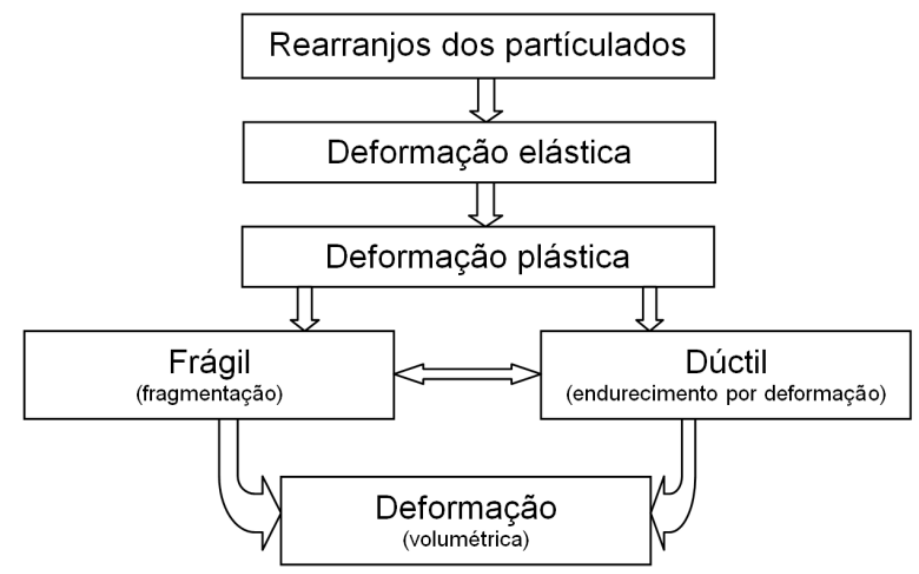

Fonte: Lower Sintering Temperature Tungsten Alloys for Space Research ].

Segundo Dowson [71] o processo de compactação tem por finalidade consolidar as partículas de pós e minimizar o contingente de poros, deste modo aumentar a densidade e a ligação entre as partículas, aumentando a superfície de contato entre elas. A porosidade afeta a microestrutura do sólido sinterizado afetando, por fim, as propriedades mecânicas do mesmo.

Dawihl e German [67,68] estudaram a influência da pressão de conformação na redução da fração de porosidade argumentando que os mecanismos de densificação ocorrem, em sua maior parte, durante o processo de sinterização, porém durante a compactação a pressão promove o rearranjo e reorientação até o limite de empacotamento máximo do pó com estreita dependência do tamanho e formato das partículas. Como resultante da pressão de compactação, as deformações elásticas e plásticas podem ocorrer associadas à fragmentação de partículas de pós constituídos de materiais mais frágeis.

Dongguo e Belk [115,116] estudaram a influência das partículas de alta dureza no comportamento da escoabilidade durante a compactação. Quando a 
dureza da partícula de um dos componentes da mistura é elevada em relação ao limite de pressão aplicado, estas partículas tendem a se rearranjar em aglomerados nos moldes de uma rede estendida pelo compactado, prejudicando o aumento da densidade a verde.

Eroglu e Bose [104,105] investigando o mecanismo de compactação concluiram que a presença de partículas de maior dureza na mistura é um mecanismo que dificulta a redução de poros durante a etapa de compactação, em decorrência da dificuldade de transmissão da pressão de entre as partículas mais dúcteis da mistura. Este mecanismo dificulta o empacotamento, em razão da rede de aglomerados de partículas duras.

O comportamento plástico dos metais na mistura é o principal mecanismo de aumento da densidade, ao contrário do comportamento elástico que age no sentido de provocar micro-fraturas e aumento do volume dos poros no compactado, após o relaxamento da pressão (mecanismo spring back) $[88,90,106]$.

O controle da recuperação elástica durante a etapa de extração do compactado verde é importante para evitar a ocorrência de trincas e pode ser auxiliado por adição de aglomerantes e lubrificantes orgânicos, ou aditivos de compactação. Estes lubrificantes, auxiliam também o escoamento e no consequente empacotamento, durante o processo de prensagem, geralmente volatilizam, deixando de fazer parte da mistura durante o processo de sinterização. Os lubrificantes e aglomerantes mais utilizados são: o estearato de zinco, $\mathrm{Zn}\left(\mathrm{C}_{18} \mathrm{H}_{35} \mathrm{O}_{2}\right) 2$, estearato de lítio, $\mathrm{Li}\left(\mathrm{C}_{18} \mathrm{H}_{35} \mathrm{O}_{2}\right)$ e o polietileno glicol, $\mathrm{CH}_{3} \mathrm{O}\left(\mathrm{CH}_{2} \mathrm{CH}_{2} \mathrm{O}\right) \mathrm{nCH}_{3}[68,71,96]$.

\subsubsection{Sinterização}

No processo de sinterização a energia térmica fornecida irá promover a união entre as partículas da mistura. A região de contato entre as partículas reduz a área superficial e o raio de curvatura inicial das partículas. O mecanismo de movimentação de material, na região de contato das partículas facilita a formação da região de pescoço, unindo as partículas e no processo de sinterização produz o aumento da resistência mecânica do sinterizado. O produto final tende a manter a forma, o tamanho, a qualidade do compactado verde por aplicação do adequado processo de sinterização [74,97,107]. 
Por definição no ciclo de sinterização a primeira consideração feita é como induzir o nível desejado de ligação entre os particulados, isto é, fazer com que o compactado verde adquira a resistência mecânica de corpo rígido durante a sinterização [69,98,99,103].

Durante a etapa de sinterização existem objetivos secundários a serem alcançados como a redução dos óxidos ou evitar oxidação. A relação entre a composição do material, tamanho das partículas, densidade a verde, temperatura e o tempo são importantes para a boa ligação entre as partículas. O processo de aquecimento, atmosfera, mecanismo de aquecimento, substrato e tipo do forno, são aspectos que irão influenciar nas forças de sinterização $[78,80,108]$.

A sinterização é considerada uma importante etapa no processamento de materiais, pelo uso da técnica de metalurgia do pó. É nesta etapa que o compactado a verde (massa conformada) da mistura obtida de partículas ganha resistência mecânica e adquire suas propriedades finais. É na etapa de sinterização que ocorre a densificação final do agregado de pó em contato físico por eliminação da porosidade [73,101-103].

\subsubsection{Sinterização em fase sólida}

A sinterização em fase sólida ocorre onde nenhum dos elementos atinge a temperatura de fusão. A força motriz para a densificação na sinterização em fase sólida é a mudança na energia livre, pela diminuição da área superficial das partículas, pela redução da energia livre da superfície e por substituição das interfaces sólido-vapor. Assim a força motriz fornece novas interfaces sólidosólido, mas de menor energia, resultando na diminuição total da energia livre $[78,109]$. Essa energia age na transferência de material através dos meios mais rápidos possíveis; se a transferência fosse realizada a partir do volume das partículas ou do contorno de grão das partículas, então ocorreria a redução da dimensão das partículas e consequentemente a aniquilação dos poros. A movimentação e mudança de posição de átomos dependem da energia superficial das partículas $[84,89,110]$.

German [76] relata que a força motriz no processo de sinterização em fase sólida é a energia superficial, decorrente de superfícies livres e das tensões nas regiões de interface em função da redução da área. Em escala microscópica, o mecanismo de transferência de material é afetado pela mudança de pressão e 
através de diferenças na energia livre da curvatura da superfície. Esse processo de sinterização é realizado por transporte de material por ação da difusão atômica, transporte de vapor ou fluxo viscoso. Em escala microscópica, nos processos de sinterização em estado sólido, o movimento de lacunas é resultado da mudança de posição pela movimentação dos átomos. A mecânica de movimentação atômica em um sentido promove aparecimento das lacunas que caminham no sentindo contrário.

German e Dowson [70,71] apontam que o movimento dos átomos na superfície é um efeito que pode ser entendido como movimentação das posições de vacância e discordâncias. As lacunas são resultado da movimentação dos átomos das regiões de baixa concentração de defeitos, para as regiões com alta concentração de defeitos. A movimentação de átomos e lacunas ocorre principalmente através da superfície, podendo ocorrer também pelo volume na proximidade das partículas.

A figura 3.6 ilustra, como uma sequência de trajetórias, o que pode ocorrer nos mecanismos de transporte dinâmico de átomolacuna resultando e facilitando o aumento de massa na região de pescoço $[69,70]$. A figura na trajetória (1) ilustra a formação do pescoço pelo processo de evaporação-condensação em que a movimentação pode ser facilitada pela presença de poros e decorre de movimentação dos átomos da superfície. A evaporação é um processo que tem sua dinâmica facilitada por características de superfícies planas ou convexas, já a condensação é facilitada pela presença de uma superfície côncava, de geometria em vales, como é a região de contato entre as partículas. Esta movimentação resulta no transporte de material para a região de contato entre partículas sem, contudo, ocorrer à aproximação dos centros das partículas.

O escoamento viscoso (2) ganha importância durante o aquecimento, auxiliado pela deformação plástica durante o processo de compactação, ocorrendo tipicamente em função das lacunas e das discordâncias presentes na rede cristalina atuando como facilitador no transporte de material. A eliminação de lacunas é decorrente da interação entre as lacunas e a movimentação das discordâncias.

A difusão de volume (3) acontece na região onde a força motriz esta presente pela diminuição da energia resultante de interações entre átomos e imperfeições, ou lacunas existentes na superfície das partículas. A menor energia 
de ativação do processo de difusão facilita a sua ocorrência em temperaturas inferiores à temperatura de sinterização, assim a movimentação de material acontece via superfície das partículas, não alterando o volume de poros.

A difusão de superfície (4) é favorecida pelo gradiente crescente de temperatura, sendo o mecanismo que mais contribui com a formação e ganho de massa no pescoço. A difusão que ocorre no contorno de grão (5) é ativada pela tensão e potencial químico na região onde há diferença entre os raios de curvatura o que facilita o surgimento do gradiente de concentração de lacunas, resultando no fluxo de material em sentido oposto ao fluxo de lacunas.

Figura 3.6 Diagrama esquemático ilustrando os mecanismos de transporte e movimentação de átomos e lacunas na região de contato das partículas [70].

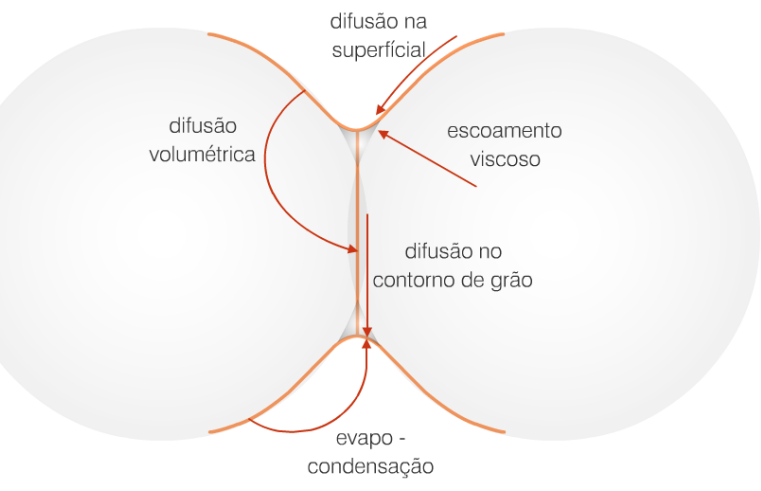

Fonte: Powder Metallurgy Particulate Materials Processi

Todos estes mecanismos influenciam o transporte, em volume, na região do pescoço. Quando o transporte tem seu fluxo originando no interior da partícula e terminando na superfície da região de pescoço, ocorre aproximação dos centros das partículas com consequente aumento de densidade podendo resultar em mudanças dimensionais por contração do compactado durante a sinterização. No transporte através da superfície não ocorre a aproximação dos centros da partícula. A temperatura e seu controle são muito importante para o processo de sinterização, uma vez que a difusão no contorno de grãos e a difusão de volume dependem fortemente da energia térmica, do tamanho, da distribuição das partículas do material, da composição dos materiais e, muitas vezes, do controle da atmosfera de sinterização [75].

\subsubsection{Sinterização por fase líquida}


A sinterização por fase líquida é empregada quando a temperatura de sinterização não pode ser propriamente atingida para que ocorra a difusão através das fronteiras das partículas resultando na adesão, ancoragem e agrupamento das partículas formando um componente sólido único. O processo de sinterização com fase líquida pode ser a via para a obtenção da conformação de sólido de alguns metais cuja temperatura de fusão é extremamente alta, tais como o tungstênio e o molibdênio [69,80].

Para os metais refratários, principalmente o tungstênio, nióbio, molibdênio e o tântalo, devido suas propriedades físico-químicas e altos pontos de fusão, os processos de fundição tradicionais geralmente não são possíveis ou economicamente viáveis. O processo de sinterização com fase líquida usando metais de transição com estrutura cristalina cúbica de face centrada como elemento da fase ligante pode ser a solução para obtenção de compósitos e ligas de diversos componentes. A combinação de metais refratários ( $\mathrm{W}, \mathrm{Mo}, \mathrm{Nb}, \mathrm{Ta}$ ) sinterizados via fase líquida em outros compósitos ou ligas viabilizam a obtenção de materiais com alta densidade, alta resistência mecânica, rigidez, boa resistência à corrosão e ao desgaste $[91,112,113]$. A sinterização com fase líquida vem sendo frequentemente aplicada na produção de muitas das ligas, com ampla aplicação na indústria automotiva, aeroespacial, nuclear e largamente utilizado na área militar como penetradores de energia cinética, de blindagem da radiação, dentre outras. Os metais como cobre, níquel, ferro e cobalto são usualmente adicionados como formadores da fase líquida para melhorar a rigidez do compósito no produto final [92,93,114].

A maioria dos metais pode ser utilizado como elementos de sinterização fase líquida. Isto se aplica especialmente aos metais puros produzidos em fornos que operam com baixa pressão (vácuo) o que impede a contaminação superficial. A sinterização sob pressão atmosférica requer, em geral, o uso de um gás protetor, geralmente gás endotérmico. Mudanças na densidade, na composição da liga ou nos tratamentos térmicos podem também alterar positivamente as características físicas dos produtos acabados [96,119].

Os movimentos de massa que ocorrem durante a sinterização com fase líquida consistem na redução da porosidade total pelo re-empacotamento, seguido pelo transporte de material por evaporação e condensação a partir da difusão. Nas etapas finais, os átomos metálicos se movem ao longo dos limites de 
cristal para as paredes dos poros internos, redistribuindo a massa do volume interno do compactado e suavizando as paredes dos poros. A sinterização com fase líquida é necessária para fazer alguns aços ferramenta como o caso do carboneto cementado, ou carboneto de tungstênio [96,120,121].

A porosidade em sinterizados pode ser explorada de modo vantajoso. $O$ bronze grafitado em particular é frequêntemente usado como material para rolamentos, pois sua porosidade permite que os lubrificantes fluam por meio dessa porosidade ou permaneçam capturados dentro delas. $O$ cobre sinterizado pode ser produzido e usado como uma estrutura de rede em certos tipos de construção de tubos de calor, onde a porosidade permite que um agente líquido se mova através do material poroso por ação capilar.

Para os materiais com alto ponto de fusão, como o molibdênio, tungstênio, rênio, tântalo, ósmio e o carbono, a sinterização é um dos poucos processos de fabricação viáveis e possíveis para produzir peças acabadas. Nestes casos, uma porosidade muito baixa é desejável. Já o bronze e o aço inoxidável sinterizados são usados como materiais filtrantes em aplicações que requerem alta resistência à temperatura, mantendo a capacidade de regenerar o elemento filtrante. Para os materiais que são difíceis de sinterizar, é comum usar o processo da sinterização em fase líquida. [89,95,122,123].

German [93] propõe que é possível distinguir três principais etapas na sinterização por fase líquida:

i) reorganização, que ocorre à medida que o líquido funde e por ação capilar, a fase líquida escoará para os poros e também fará com que os grãos se reorganizem para um arranjo de empacotamento mais favorável;

ii) solução e precipitação na qual certas áreas do compactado onde as pressões capilares são altas, isto é, as partículas estão mais próximas, alguns dos átomos preferencialmente entrarão em solução e depois precipitarão em áreas de menor potencial químico onde as partículas não estão próximas ou em contato umas com as outras;

iii) ocorrência do efeito ripening que é obtido devido à diferença dos potenciais químicos entre partículas de tamanhos diferentes e pela diferença de solubilidade, assim sendo, as partículas menores preferencialmente entrarão em solução e precipitarão sobre partículas maiores levando a densificação;

iv) densificação final ou densificação da rede com semelhança de estrutura 
sólido, o movimento de líquidos em poros das regiões de empacotamento ocorre mais eficientemente. Para que a sinterização em fase líquida seja prática, a fase principal deve ser pelo menos ligeiramente solúvel na fase líquida e o elemento aditivo deve se fundir antes de ocorrer qualquer sinterização de partículas sólidas do componente matriz, caso contrário não haverá rearranjo de grãos.

A sinterização com fase líquida é aplicável para ligas de $\mathrm{Cu}-\mathrm{Ni}$ onde o metal matriz ou tem alto ponto de fusão, caso dos metais refratários. Cobre e níquel formam ligas nas quais, geralmente, o metal predominante é o cobre, o níquel aparece na composição com menor massa acompanhado ou não de outros elementos. O níquel, porém não pode ter teor de zinco superior a $1 \%$ em massa $[118,124]$. Quando outros elementos estão presentes na liga de cobre, o níquel deve ser o segundo elemento em conteúdo individual em relação ao cobre e o maior em massa em relação ao conteúdo dos outros elementos [94,96,].

$\mathrm{Na}$ sinterização com fase líquida, o método de prensagem isostática à frio (cold isostatic pressing - CIP) em pressões até $200 \mathrm{MPa}$ podem ser usadas possibilitando conseguir densidade do compactado verde até $60 \%$ a $70 \%$, em relação a densidade teórica [92,93]. No mesmo processo de compactação por prensa axial, para obter um corpo verde que atinge densidades na faixa de $70 \%$ a $90 \%$ em relação à densidade teórica, a prensagem deve estar na faixa entre 200 MPa e 663 MPa [92].

O níquel como metal, sem o conhecimento prévio de sua existência, já era usado na composição de ligas a cerca de dois milênios. Isso é confirmado em moedas da época que continham $10 \%$ de níquel, além de cobre. A mais antiga moeda de liga Cu-Ni é datada de dois séculos aC. A liga Cu-Ni vem sendo usada desde a antiguidade, na razão em massa de $75 \%$ Cu e $25 \%$ Ni e atualmente é parte importante na moeda de 0,25 US\$ de dólar, por apresentar boa resistência à corrosão (pocketage), o que indica a alta durabilidade desta liga $[63,94,133]$. Em alguns casos onde é necessário, adicionalmente melhorar propriedades elétrica, as ligas Cu-Ni recebem a adição do manganês. O sistema Cu-Ni-Mn passa a apresentar melhor condutividade e maior resistência ao desgaste por formação de arco elétrico, indicado para a fabricação de contatos e terminais elétricos [93]. A adição de ferro ao sistema $\mathrm{Cu}-\mathrm{Ni}$ melhora significativamente a resistência à erosão e corrosão em meios líquidos, principalmente na água salina $[93,98]$. 


\subsubsection{Obtenção dos compósitos de blindagem}

O tungstênio é encontrado na natureza, mais comumente em minérios wolframita na forma do óxido de tungstato $\left(\mathrm{WO}_{3}\right)[62,122]$. O tungstênio metálico é produzido por diversas rotas de redução química resultando em um pó-metálico $[65,125]$. O tungstênio é considerado o principal elemento do grupo dos refratários junto com o nióbio, molibdênio e tântalo. A propriedade de densidade do tungstênio $\left(19,250 \mathrm{~g}^{\mathrm{cm}}{ }^{-3}\right)$ quando comparada a densidade do urânio empobrecido $\left(19,1 \mathrm{~g}_{\mathrm{cm}} \mathrm{cm}^{-3}\right)$, chumbo $\left(11,340 \mathrm{~g} \cdot \mathrm{cm}^{-3}\right)$, cobre $\left(8,89 \mathrm{~g} \cdot \mathrm{cm}^{-3}\right)$, níquel $\left(8,83 \mathrm{~g} \cdot \mathrm{cm}^{-3}\right)$, e do ferro $\left(7,870 \mathrm{~g} \cdot \mathrm{cm}^{-3}\right)$, o torna o elemento adequado à função de blindagem contra a radiação [44,57].

A densidade do tungstênio é uma propriedade importante e necessária aos materiais que podem produzir o efeito de atenuação da intensidade e energia da radiação [91,92]. As ligas e compósitos metálicos de tungstênio já vem há muito tempo sendo utilizadas na indústria eletroeletrônica para a fabricação de válvulas termiônicas e tubos fonte de raios $\mathrm{X}$, onde é muito empregado o compósito do tungstênio-níquel fabricado por metalurgia do pó. Neste caso o processo de produção de um compactado verde usa partículas de níquel com o tamanho médio de 0,3 $\mu \mathrm{m}$ e partículas de tungstênio do com o tamanho médio de 0,8 $\mu \mathrm{m}$.

Os sinterizados de densidade superior a $80 \%$ foram obtidos no início da segunda metade do século $X X[92,103]$. A indústria de materiais elétricos tem a necessidade de materiais que possuam propriedade de alta resistência à corrosão e resistência de contato durante a formação de arcos em alta tensão. Essa necessidade influenciou o desenvolvimento do uso de ligas e compósitos metálicos obtidos por técnicas de metalurgia do pó $[62,106]$. As ligas e superligas metálicas do sistema W-Ni-Co com diferentes proporções de Ni/Co vem, há muito, sendo empregadas e investigadas para essa finalidade $[107,108,110]$.

Os materiais usualmente utilizados na função de atenuação e blindagem contra a radiação são chumbo e em algumas aplicações o urânio empobrecido [3, 46]. Materiais com alta densidade eletrônica, consequentemente alto número atômico, têm boas propriedade físico-química para atuar como material de atenuação da radiação eletromagnética, já que a atenuação da radiação é um processo de redução da energia do fóton, basicamente por interação de choque entre o fóton e os elétrons dos átomos do material. Além de chumbo e urânio empobrecido, o tungstênio vem sendo produzido como liga ou compósito com 
outros elementos e é aplicado na indústria nuclear [3,40,57].

A dificuldade de se alcançar densidades mais próximas da teórica para o sistema W-Cu na sinterização com fase líquida, decorre da não solubilidade do tungstênio no cobre $[23,128]$. A temperatura de sinterização indicada para obter melhor resultado no sinterizado deve superar os $1550^{\circ} \mathrm{C}[110,126,127]$. Para se obter componentes W-Cu produzidos por sinterização fase líquida com densidade superior a 70\% deve-se alcançar a distribuição homogênea de partículas de tungstênio no cobre fundido e o corpo verde deve partir de partículas muito finas o que facilita a dispersão de ambos os metais [110,112,134].

Gatti [91] conseguiu uma patente para o processo de sinterização com fase líquida para o sistema W-Ni que foi proposto pela GE (Company Corporation), em 1963. A razão em massa da composição proposta foi 99,5 em massa de tungstênio e 0,5 em massa de níquel. O diâmetro declarado das partículas do pó tungstênio foi de 0,8 $\mu \mathrm{m}$ e para o pó de níquel foi de $0,3 \mu \mathrm{m}$. A mistura foi inicialmente prensada com 60 ton. in $^{2}$ e o compactado foi levado à sinterização em atmosfera ar, entre temperaturas não inferior $1050^{\circ} \mathrm{C}$ e não excedeu $1500{ }^{\circ} \mathrm{C}$. $\mathrm{O}$ tempo de sinterização declarado foi entre $30 \mathrm{~min}$ e $240 \mathrm{~min}$. Foi declarado que a densidade obtida ficou em $68,5 \%$ da densidade teórica da mistura.

Oqail [106] investigou os parâmetros de processo do compósito de tungstênio-cobre (W-Cu) para aplicações gerais onde requisitos da forma de produto quase acabada estavam em análise. As composições examinadas foram $20 \%, 25 \%$ e $30 \%$ em massa, aplicando a técnica de mistura úmida dos pós elementares. A forma, tamanho das partículas dos pós como recebidos que foram usados para a obtenção das misturas foram examinadas por microscopia eletrônica de varredura e foi observado que as partículas de tungstênio estavam com diâmetro na faixa de $0,25 \mu \mathrm{m}$ a $1 \mu \mathrm{m}$, enquanto as partículas de cobre estavam com diâmetro na faixa de $10 \mu \mathrm{m}$ a $60 \mu \mathrm{m}$. As misturas tiveram a adição de parafina, como lubrificante, em sua composição. Esta composições foram misturadas e ao mesmo tempo trituradas, em moinho do tipo barras de aço cilíndricas, na razão em volume de 3:1. A mistura e moagem foram realizadas com rotações do vaso em 140 rpm por $360 \mathrm{~min}$. Foi usado o processo de compactação a frio e foram aplicadas pressões de $300 \mathrm{MPa}$ até $1200 \mathrm{MPa}$. A técnica aplicada no processo de sinterização foi a de atmosfera de baixa pressão (vácuo $10^{-2}$ Torr, ) em patamar de temperatura de $1400{ }^{\circ} \mathrm{C}$ por $60 \mathrm{~min}$ e $120 \mathrm{~min}$. A 
microestrutura foi posteriormente examinada por microscopia eletrônica de varredura (MEV). A densidade relativa obtida para os sinterizados ficou entre $96,06 \%$ e $98,01 \%$. A dureza Vickers para os sinterizados com tempo de rampa de 60 minutos foi de $170 \mathrm{HV}$ em média enquanto que para os sinterizados com tempo de rampa de 120 min constatou-se que a dureza alcançou, em média, $250 \mathrm{HV}$.

Piotter e seus colaboradores [109] investigaram um novo processo metalúrgico para desenvolvimento de componentes para um reator experimental de fusão nuclear, em particular, a produção de um separador de sobras ou "cinzas" (partículas alfa) tidos como resíduos do combustível não queimado. As peças a utilizadas no separador tinham dimensões micrométricas $(0,6 \mu \mathrm{m})$. Em 2008 a técnica microPIM (micro powder injection molding) que estava em desenvolvimento apresentou-se como solução viável e foram experimentalmente produzidas com pó de tungstênio no sistema W-La.

A técnica PIM já vem sendo utilizada em muitas aplicações de material metálico, ou cerâmico, para viabilizar custo em larga escala de produção de peças complexas com acabamento final na forma pretendida (near net shape). Atualmente esta técnica é, geralmente, usada na produção de termoplásticos. A moldabilidade e o acabamento superficial desejável é alcançado pela qualidade e tamanho obtido nas partículas do pó de tungstênio. As micropeças são produzidas pela clássica técnica de metalurgia do pó (PM). Peças anteriormente produzidas em aço $316 \mathrm{~L}$ ou $17-4 \mathrm{PH}$ alcançaram densidade acima de $97 \%$ da densidade teórica. As tolerâncias obtidas nas dimensões nominais $(600 \mu \mathrm{m})$ das peças pós sinterizadas ficaram na faixa de $\pm 0,7 \%$ e $\pm 0,4 \%$ podendo ter sua precisão melhorada. No uso do pó de tungstênio, as partículas tinham a característica de aglomerados submicrométrico em forma de esponja e com tamanho inferior a $1 \mu \mathrm{m}[129,131]$.

As partículas de aglomerados de tungstênio não puderam ser divididas durante o processo de compactação por PIM e foi então necessário fazer uso de pré-moagem usando moinho de jatos. Para o processo de sinterização foi aplicada temperatura de $1.600{ }^{\circ} \mathrm{C}$ por 120 minutos em atmosfera seca de $\mathrm{H}_{2}$ sob pressão de 2.500 bar. As amostras finais alcançaram valores de densidade próximo da densidade teórica, com tamanho de grão de aproximadamente $5 \mu \mathrm{m}$. Como parâmetro de resultado eles obtiveram resistência de $150 \mathrm{MPa}$ em força de 
tração, abaixo do valor desejado. Sendo necessário superar este problema viabilizando novas composições.

Em recente estudo Wu e German [103] investigaram a densificação e a distorção resultante durante o processo de sinterização com fase líquida do sistema W-Ni-Cu. Utilizaram como composição em massa dos elementos: $80 \% \mathrm{~W}$, $14 \% \mathrm{Ni}$ e $6 \% \mathrm{Cu}$ em massa. $\mathrm{O}$ pó de tungstênio como recebido foi primeiramente desaglomerado em misturador Turbula por 20 minutos para alcançar melhor homogeneidade da mistura. Na compactação foi aplicada pressão de $175 \mathrm{MPa}$. Após a compactação as amostras de mistura foram secas em atmosfera redutora com gás hidrogênio em temperatura de $550{ }^{\circ} \mathrm{C}$. Neste ponto do processo a densidade atingida para o compactado foi de $61 \pm 0,5 \%$ da densidade teórica.

Neste processo de sinterização foi testado atmosfera de argônio e para o ciclo temperatura de sinterização aplicou-se rampa de $10^{\circ} \mathrm{C} \cdot \mathrm{min}^{-1}$, até atingir 900 ${ }^{\circ} \mathrm{C}$ mantendo-se neste patamar por $60 \mathrm{~min}$. Em sequência aplicou-se o mesmo gradiente de temperatura até atingir $1.490{ }^{\circ} \mathrm{C}$, que foi mantida por $5 \mathrm{~min}$, com subsequente resfriamento a taxa de $10{ }^{\circ} \mathrm{C} \cdot \mathrm{min}^{-1}$. O uso adicional de testes de dilatometria mostrou que o parâmetro utilizado no forno resultou densificação do compactado associada a uma microestrutura satisfatória. Concluíram que na obtenção de ligas metálicas pesadas de tungstênio (tungsten heavy alloys WHAs) o propósito visado, alcançar uma densificação total e rápida sem distorção foi parcialmente atingido. A janela de sinterização aplicada é geralmente estreita, especialmente quando existe excesso de metal líquido com alta solubilidade junto do tungstênio. A densificação ocorre primeiro e, em seguida, uma distorção significativa ocorre quando a densidade total é desejada.

Chen [110,111] investigou as características e comportamento do compósito do sistema $\mathrm{W}-\mathrm{Ni}-\mathrm{Co}$ como ligas metálicas pesadas de matriz tungstênio produzidas pelo método de moagem em que testou a composição $\mathrm{W}$ $7 \mathrm{Ni}$-3Co. Nos ensaios foi usado moinho de bolas de alto impacto, aplicando a técnica de moagem secundária da fase $\mathrm{Y}(\mathrm{Ni}-\mathrm{Co})$ em tempos de $16 \mathrm{~h}$ e $24 \mathrm{~h}$. $\mathrm{O}$ objetivo era obter a redução de grãos na microestrutura durante a formação da fase sólida na sinterização. Como resultado foi obtido uma microestrutura refinada e de grãos uniformemente distribuídos com uma grande quantidade de estruturas geminadas com o consequente aumento da resistência mecânica. Após a obtenção do sinterizado foi feito o ensaio de dureza Vickers para diferentes 
composições de amostras sinterizadas. Os valores médio de dureza ficaram na faixa de $350 \mathrm{HV}$ para composição Ni/Co=2,3 e $568 \mathrm{HV}$ para a composição Ni/Co = 9. O ganho na média de dureza foi atribuída a transição de fase sólido-liquido, com altas taxas de difusão do níquel em estado líquido durante a sinterização, o que melhora as taxas de transporte de material responsáveis pelo crescimento de grão e de aumento na densificação final do sinterizado. 


\section{MATERIAIS E MÉTODOS}

A figura 4.1 apresenta o fluxograma das etapas adotadas para a obtenção das amostras de misturas de compósito do sistema W-Cu, W-Ni e W-Cu-Ni.

Figura 4.1 Fluxograma do processo de obtenção do compósito dos sistemas W-Cu e W-Cu-Ni e das etapas para a caracterização de propriedades das amostras de material obtido e ensaios experimentais em atenuação e blindagem contra radiação.

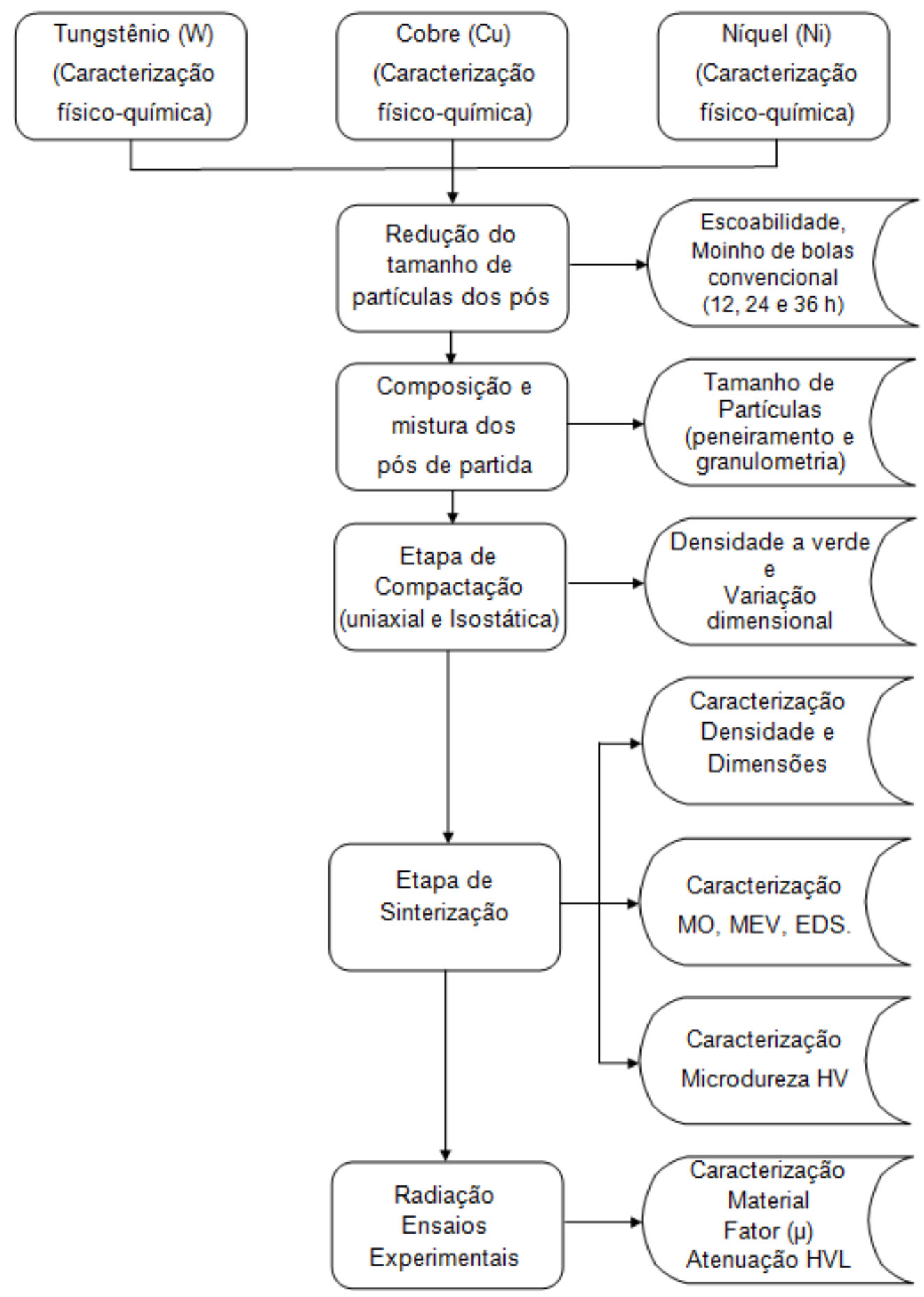

Fonte: criada pelo autor 


\subsection{Matérias-primas}

Para o preparo das amostras foram usados três pós-metálicos elementares; tungstênio, cobre e níquel. O pó de tungstênio foi selecionado como elemento matriz. Os pós de cobre e níquel foram empregados em diferentes percentuais em peso com o objetivo de obter a sinterização com fase líquida para os sistemas W-Cu, W-Ni e W-Cu-Ni.

A tabela 4.1 apresenta as principais características informadas pelos fornecedores dos pós de partida dos metais tungstênio, cobre e níquel que foram utilizados na preparação das amostras.

Tabela 4.1 Identificação dos pós metálicos e características de como recebido.

\begin{tabular}{llccc}
\hline $\begin{array}{l}\text { Identificação } \\
\text { (matéria-prima) }\end{array}$ & $\begin{array}{l}\text { Fornecedor } \\
\text { (Origem) }\end{array}$ & $\begin{array}{l}\text { Quantidade } \\
\text { recebida }(\mathrm{g})\end{array}$ & $\begin{array}{l}\text { Pureza } \\
\text { declarada } \\
(\%)\end{array}$ & $\begin{array}{l}\text { Tamanho médio } \\
\text { de partícula } \\
\text { declarado }(\mu \mathrm{m})\end{array}$ \\
\hline Tungstênio (1) & China Trade USA & 1550 & 98,90 & 63,0 \\
\hline Tungstênio (2) & $\begin{array}{l}\text { Chemsavers - } \\
\text { USA }\end{array}$ & 850 & 99,95 & 32,0 \\
\hline Tungstênio (3) & Marinha do Brasil & 270 & $\mathrm{n} / \mathrm{c}$ & 27,0 \\
\hline Tungstênio (4) & Aldrich - USA & 1120 & 99,90 & 12,0 \\
\hline $\begin{array}{l}\text { Cobre } \\
\text { eletrolítico }\end{array}$ & China Trade USA & 350 & 98,50 & 10,0 \\
\hline Cobre PAC & $\begin{array}{l}\text { Metalpó } \\
\text { Combustol - Brasil }\end{array}$ & 400 & 98,00 & 10,0 \\
\hline Cobre PAM & $\begin{array}{l}\text { Metalpó } \\
\text { Combustol - Brasil }\end{array}$ & 400 & 97,00 & 28,0 \\
\hline Níquel (1) & Novamet - USA & 550 & 99,90 & 37,0 \\
\hline Níquel (2) & $\begin{array}{l}\text { Cromato Produtos } \\
\text { Químicos - Brasil }\end{array}$ & 450 & 99,90 & 25,0 \\
\hline
\end{tabular}

Fonte: criação do autor

\subsection{Processamento}

Os pós como o recebido foram processados por etapas de caracterização, para determinar suas propriedades iniciais. Foram feitos testes para determinar:

1 - Escoabiliade;

2 - Distribuição de tamanho das partículas;

3 - Morfologia das partículas; e

4 - Composição química. 


\subsubsection{Escoabilidade dos pós}

A escoabilidade foi medida utilizando funil e recipiente graduado sendo feito ensaio de determinação da densidade aparente $(\mathrm{g} / \mathrm{mL})$ e densidade batida para o tungstênio conforme recebido. Aplicou-se a técnica de fluxo do funil Hall que tem o método descrito pela Norma brasileira ABNT NBR-9935 NM52 ou a Norma ASTM B212-09 [83].

A densidade aparente e taxa de fluxo dos pós como recebido foram testados para escoabilidade (taxa de fluxo), seguindo a norma ASTM B 213 [84]. As condições ambientais durante os ensaios foi de $25{ }^{\circ} \mathrm{C}$ e umidade relativa do ar de $81 \%$. Foi utilizado o Funil de Hall para densidade de pós do Laboratório de Materiais Magnéticos do CCTM/IPEN. Foi utilizado tempo de 30 segundos no dispositivo de acomodação de partículas por vibração, para medida de densidade batida [87].

\subsubsection{Peneiramento}

Foi utilizado um conjunto de peneiras para separação do volume dos pós, precursor do tungstênio cobre e níquel. Após processo de moagem foi novamente aplicado o teste de peneiramento, para determinar a evolução de propriedades desejadas para os pós iniciais.

A norma técnica brasileira ABNT NBR-NM 248 [82] é que orienta sobre a aplicação do teste de peneiramento para determinar tamanho de particulados e aglomerados de partículas de pós-metálicos e é compatível com a norma americana ASTM B214-16. O guia ASTM E2651-13 apresenta maiores informações de aplicação da técnica de peneiramento [86-86].

\subsubsection{Granulometria}

O pó de tungstênio cobre e níquel como recebido e as amostras após ação do moinho de bolas foram caracterizados usando difração Fraunhofer feixe laser no equipamento, marca CILAS modelo 1064 opera com laser $820 \mathrm{~nm}$ com determinação da distribuição granulométrica de pós, pelo método Fraunhofer e Mie.

\subsubsection{Microscopia eletrônica de varredura - MEV}


Foi utilizado aplicada a microscopia eletrônica de varredura MEV para determinar a morfologia dos particulados dos pós de tungstênio, cobre e níquel como recebido. Foi utilizado o equipamento de microscopia MEV - TM300 do Laboratório de Microscopia do CCTM.

\subsubsection{Composição química}

Depois foi realizada a caracterização da composição química dos pós de tungstênio, cobre e níquel, como recebido. O método de análise da concentração dos elementos foi semi quantitativa utilizando a técnica de fluorescência por emissão de energia dos raios $X$ característicos ED-XRF (energy dispersive $X$-ray fluorescence).

\subsubsection{Moagem}

O processo de moagem, por moinho de esferas é um método clássico, aplicado para a redução de tamanho de partículas em pós de material frágil. Inicialmente os pós precursores foram processados individualmente em moinho convencional para redução de tamanho de partículas por ação de choque mecânico do pó com esferas. A figura 4.2 apresenta um diagrama esquemático do moinho de bolas convencional.

Figura 4.2 Diagrama esquemático do moinho de bolas (esferas) utilizado no processo de moagem para obtenção do compósito dos sistemas W-Cu e W-Cu-Ni.

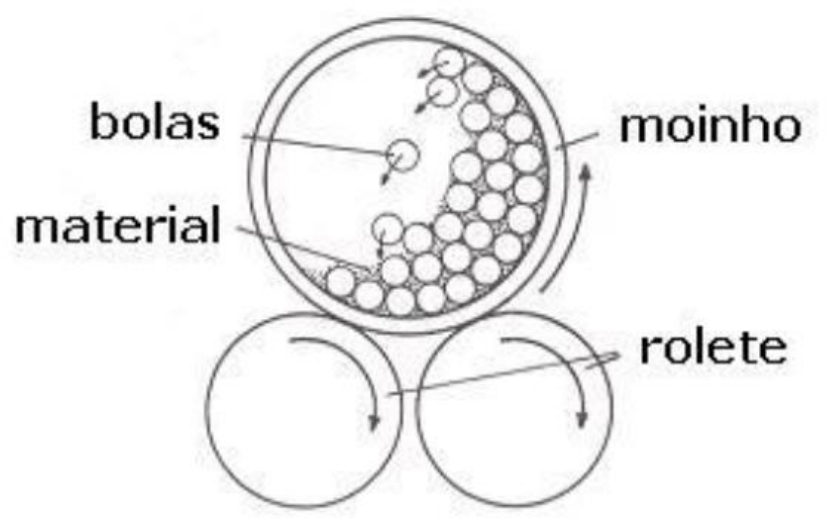

Fonte: criação do autor

Os tempos de ação de moagem foram de 12 h, 24 h e 36 h. Foram utilizadas um conjunto de 10 esferas de alumina com diâmetro de $10 \mathrm{~mm}$ e 20 esferas de alumina com diâmetro de $5 \mathrm{~mm}$. Após o processo de moagem foram 
retiradas amostras de pós para serem verificadas as alterações quanto ao tamanho e forma das partículas dos pós.

\subsubsection{Preparação das misturas}

Após as etapas de caracterização de tamanho, propriedades químicas e as misturas dos pós foram novamente trituradas no moinho de bolas como ação de misturador para preparar as amostras em composições distintas, como ilustra a tabela 4.2. Na composição dos pós foram adicionados aditivos com a função de lubrificante para a fase de compactação, nas proporções em massa de 0,4\%, sendo $0,2 \%$ de estearato de zinco e $0,2 \%$ de estearato de lítio.

Tabela 4.2 Composição nominal em massa das misturas do sistema W-Cu, W-Cu-Ni e W-Ni após moagem.

\begin{tabular}{lll}
\hline Mistura & Nomenclatura & Composição (\% em massa) \\
\hline 01 & W1Ni & $99,0 \% \mathrm{~W}+1,0 \% \mathrm{Ni}$ \\
\hline 02 & W0,5Ni & $99,5 \% \mathrm{~W}+0,5 \% \mathrm{Ni}$ \\
\hline 03 & W5Cu & $95,0 \% \mathrm{~W}+5,0 \% \mathrm{Cu}$ \\
\hline 04 & W25Cu & $75,0 \% \mathrm{~W}+25,0 \% \mathrm{Cu}$ \\
\hline 05 & W20Cu & $80,0 \% \mathrm{~W}+20,0 \% \mathrm{Cu}$ \\
\hline 06 & W15Cu & $85,0 \% \mathrm{~W}+15,0 \% \mathrm{Cu}$ \\
\hline 07 & W10Cu & $90,0 \% \mathrm{~W}+10,0 \% \mathrm{Cu}$ \\
\hline 08 & W10Cu3N & $87,0 \% \mathrm{~W}+10,0 \% \mathrm{Cu}+3,0 \% \mathrm{Ni}$ \\
\hline 09 & W10Cu1,5N & $88,5 \% \mathrm{~W}+10,0 \% \mathrm{Cu}+1,5 \% \mathrm{Ni}$ \\
\hline 10 & W8Cu3Ni & $89,0 \% \mathrm{~W}+8,0 \% \mathrm{Cu}+3,0 \% \mathrm{Ni}$ \\
\hline 11 & W8Cu1,5Ni & $89,0 \% \mathrm{~W}+8,0 \% \mathrm{Cu}+1,5 \% \mathrm{Ni}$ \\
\hline 12 & W6Cu3Ni & $91,0 \% \mathrm{~W}+6,0 \% \mathrm{Cu}+3,0 \% \mathrm{Ni}$ \\
\hline 13 & W6Cu1,5Ni & $92,5 \% \mathrm{~W}+6,0 \% \mathrm{Cu}+1,5 \% \mathrm{Ni}$ \\
\hline 14 & W6Cu1Ni & $93,0 \% \mathrm{~W}+6,0 \% \mathrm{Cu}+1,0 \% \mathrm{Ni}$ \\
\hline
\end{tabular}

Fonte: criada pelo autor

Estas composições foram levadas ao misturador modelo mecânico orbital do modelo Turbula. As mistura foram mecanicamente agitadas no equipamento em intervalos de tempo de 120 min (7200 s), para atingir homogeneidade na mistura.

As amostras dos sistemas $\mathrm{W}-\mathrm{Cu}, \mathrm{W}-\mathrm{Ni}$ e $\mathrm{W}-\mathrm{Cu}-\mathrm{Ni}$ foram preparadas com 
diferentes percentuais de cobre e cobre níquel para experimentalmente, definir a menor fração em massa destes elementos para uso na sinterização com fase líquida de forma que resultasse em aglomerado sólido, de dureza apropriada para a função de material de blindagem da radiação.

\subsection{Compactação}

Para a compactação das amostras foram usadas quatro tipos de prensas:

- prensa uniaxial até $30 \mathrm{~T}$;

- prensa uniaxial até $80 \mathrm{~T}$;

- prensa uniaxial dupla ação 100 T;

- prensa isostática.

Foram também usadas três diferentes conjuntos de matrizes cilíndricas com diâmetros de $10,0 \mathrm{~mm}, 25,5 \mathrm{~mm}$ e de $30,0 \mathrm{~mm}$. As matrizes usadas para compactação foram diferenciadas em função do diâmetro e dos mecanismos de ancoramento mecânico das matrizes nas prensas disponíveis.

As dimensões e massa de todas as amostras compactadas a verde foram medidas. Para obter as medidas das dimensões foi usando um micrômetro digital com precisão de $\pm 0,001 \mathrm{~mm}$ e para medir a massa foi utilizada uma balança digital com precisão de $\pm 0,001 \mathrm{~g}$. A densidade dos compactados a verde (dv) e a densidade dos sinterizados (ds) foram obtidas pelo cálculo clássico do método geométrico (massa/volume).

\subsubsection{Compactação uniaxial}

A prensa uniaxial hidráulica convencional de até $30 \mathrm{~T}$ foi usada com a matriz de 25,3 mm de diâmetro para compactação nas pressões de $80 \mathrm{MPa}, 120$ MPa e $180 \mathrm{MPa}$ por tempo de 270 s. Esta prensa foi disponibilizada pelo Laboratório de Cerâmica do Centro de Ciência e Tecnologia dos Materiais (CCTM).

A prensa hidráulica convencional de até $80 \mathrm{~T}$ foi utilizada com a matriz de 25,3 mm de diâmetro para compactação uniaxial nas pressões de $450 \mathrm{MPa}$ e 550 MPa por 270 s. A prensa é um equipamento Forney Corporation disponibilizada pelo Laboratório de Engenharia Civil da Universidade Federal do Mato Grosso do Sul, UFMS - Campo Grande.

A prensa uniaxial de dupla ação hidráulica automatizada de até $100 \mathrm{~T}$ foi 
utilizada com matriz de 30,0 mm de diâmetro nas pressões de compactação de $450 \mathrm{MPa}$ e $550 \mathrm{MPa}$ por tempo de $180 \mathrm{~s}$. A prensa foi utilizada no Centro de Processamento de Pós (CPP) do Instituto de Pesquisas Energéticas e Nucleares (IPEN).

\subsubsection{Compactação isostática}

A prensa hidráulica isostática de até 35000 psi foi utilizada com matriz de $10,0 \mathrm{~mm}$ de diâmetro nas pressões de $180 \mathrm{MPa}, 210 \mathrm{MPa}$ por tempo de 180 segundos. A prensa foi utilizada no Laboratório de Cerâmica do Centro de Ciência e Tecnologia dos Materiais (CCTM).

\subsection{Sinterização}

As amostras de misturas foram submetidas a processos de sinterização utilizando-se de quatro diferentes tipos de forno:

- forno elétrico convencional;

- forno industrial de esteira;

- forno a vácuo;

- forno tubular.

No forno convencional elétrico foi usado sinterização em atmosfera ao ar. Para os outros fornos foram preparadas atmosferas com gases de hidrogênio, nitrogênio e argônio elementares, ou em composições para compor a atmosfera redutora, ou protetiva no processo de sinterização.

\subsubsection{Forno convencional}

Para sinterizar um primeiro grupo de amostras foi utilizado o forno convencional resistivo do Laboratório de Metalografia e Metalurgia do Pó que pertence ao CCTM/IPEN. Os parâmetros de sinterização aplicados foram; temperatura inicial a $25^{\circ} \mathrm{C}$ ao ar, rampa de aquecimento de $15^{\circ} \mathrm{C} / \mathrm{min}$ até 1050 ${ }^{\circ} \mathrm{C}$, patamar em $1050^{\circ} \mathrm{C}$ por 60 min e rampa de resfriamento de $12{ }^{\circ} \mathrm{C} / \mathrm{min}$, até o retorno a temperatura ambiente.

\subsubsection{Forno industrial de esteira}

Um segundo grupo de amostras foram sinterizadas em forno do tipo esteira 
industrial. O forno que pertence a empresa Combustol \& Metalpó Indústria e Comércio Ltda., unidade Jd. Mutinga em São Paulo, capital. Foi usado parâmetros de controle de temperatura programável, com rampa de aquecimento, com a taxa de $28,0^{\circ} \mathrm{C} / \mathrm{min}$, patamar a $1150,0^{\circ} \mathrm{C}$ por 210 min e resfriamento a taxa de $18,5{ }^{\circ} \mathrm{C} / \mathrm{min}$ até $40,0^{\circ} \mathrm{C}$ e sendo aplicado atmosfera com fluxo de gás $70 / 30$ industrial ( $70 \%$ nitrogênio e $30 \%$ hidrogênio). Na figura 4.3 é apresentada as etapas da sinterização em fornos do tipo esteira.

Figura 4.3 Diagrama esquemático do ciclo de sinterização em forno industrial tipo de esteira contínua (adaptado de Neves) [63].

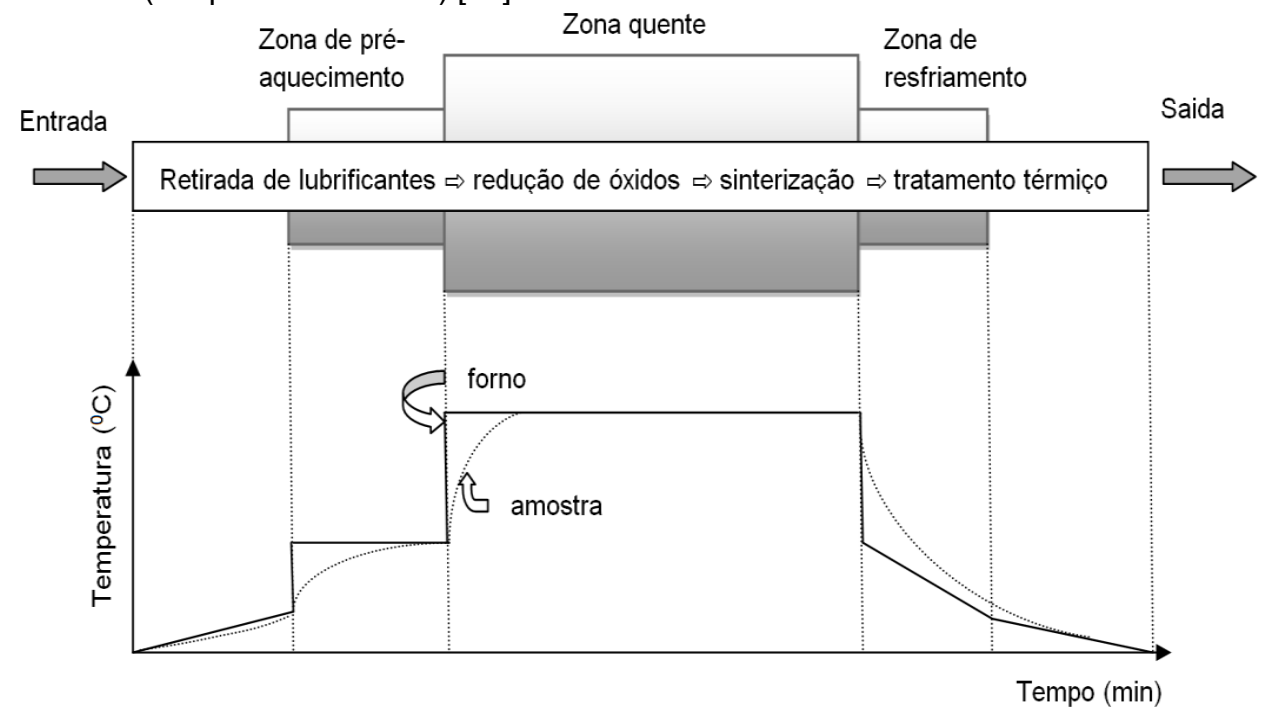

Fonte: Sinterização de Misturas de Pós de Ligas de Ferro Para Aplicações Automotivas

\subsubsection{Forno a vácuo}

A sinterização de um terceiro grupo de amostras foi realizada em forno a vácuo com bomba mecânica que pertence ao CCTM/IPEN, no Laboratório de Materiais Magnéticos. Para os parâmetros térmicos de sinterização foi utilizado atmosfera redutora de $\mathrm{H}_{2}$ a 1.100 mbar de pressão e a temperatura programada no controle do forno foi: rampa de aquecimento de $7,0^{\circ} \mathrm{C} / \mathrm{min}$ entre $20^{\circ} \mathrm{C}$ e 1.100 ${ }^{\circ} \mathrm{C}$, patamar em $1.100^{\circ} \mathrm{C}$ por $12 \mathrm{~h}$ e rampa de resfriamento entre $1.100^{\circ} \mathrm{C}$ e $23^{\circ} \mathrm{C}$ realizado em um período de $12 \mathrm{~h}$.

\subsubsection{Forno tubular}

Foi utilizado forno tubular com controle de programação de parâmetros de aquecimento e uso de fluxo forçado em atmosfera de gás de proteção contra oxidação que pertence ao Laboratório de Engenharia Civil da Universidade 
Federal do Mato Grosso do Sul (UFMS). Na sinterização das amostras do sistema W-Cu-Ni foi usado fluxo contínuo de $450 \mathrm{ml}$ de gás argônio, para proteção contra oxidação. Para um primeiro grupo de amostras, o ciclo térmico adotado no processo de sinterização foi rampa com taxa de $50,0^{\circ} \mathrm{C} / \mathrm{min}$, partindo de $27,0^{\circ} \mathrm{C}$ (ambiente) até $1300^{\circ} \mathrm{C}$, patamar de $1300^{\circ} \mathrm{C}$ por 30 min e resfriamento na taxa de $12,0^{\circ} \mathrm{C} / \mathrm{min}$ até $30^{\circ} \mathrm{C}$. Um segundo grupo de amostras teve o ciclo térmico com rampa de $29,0{ }^{\circ} \mathrm{C}$ (ambiente) até $1.400{ }^{\circ} \mathrm{C}$ em $35 \mathrm{~min}$, taxa de $42,0{ }^{\circ} \mathrm{C} / \mathrm{min}$, patamar de $1400{ }^{\circ} \mathrm{C}$ por $30 \mathrm{~min}$ e taxa de resfriamento de $15,5^{\circ} \mathrm{C} / \mathrm{min}$ até $45^{\circ} \mathrm{C}$. A atmosfera teve fluxo alterado para 800 ml de gás argônio.

\subsection{Microscopia}

\subsection{1 Ótica (MO)}

Foi utilizada a técnica de microscopia óptica para investigar as características superficiais e a distribuição das estruturas de cobre, cobre-níquel nas amostras compactadas a verde e possíveis fissuras e trincas decorrentes do efeito de relaxamento elástico, na ejeção no processo de compactação. Nas amostras sinterizadas foi investigada a porosidade e a liga sólida resultante da formação das fases líquidas de cobre $(\mathrm{Cu})$, de níquel $(\mathrm{Ni})$ e de liga cobre-níquel (CuNi). Como forma de inferir sobre as características mecânicas no sinterizado, coube investigar $\mathrm{o}$ espalhamento dos particulados de tungstênio nos aglomerados. Foi utilizado o microscópio óptico marca Leica, modelo LAS-EZ, com câmera e software Leica Application do Laboratório de Corrosão.

Foi empregado a técnica de microscopia eletrônica de varredura (MEV) pelo uso do equipamento Hitachi TM3000 do Laboratório de Microscopia do CCTM. O uso das técnicas de microscopia é complementado pela microscopia eletrônica. A microscopia MEV foi empregada para observar a morfologia dos pós de partida (como recebido), permitindo avaliar de forma qualitativa as características de morfologia e homogeneidade das partículas. A técnica foi também utilizada para determinar o grau de porosidade residual e a uniformidade na distribuição das partículas de tungstênio $(W)$, na fase líquida, formada entre cobre e níquel ( $\mathrm{Cu}, \mathrm{Cu}-\mathrm{Ni})$ na composição das fase nas amostras, após a sinterização.

\subsubsection{Microscopia MEV com EDS}


A técnica de microscopia MEV associada a espectroscopia de energia dispersiva - EDS foi utilizada para caracterizar a distribuição dos elementos

químicos na superfície da amostra após sinterizada. A análise por espectroscopia de energia dispersiva determina de forma semiquantitativa (percentual relativo de cada elemento) a razão de cada elemento na composição. A técnica pode também determinar a existência de elementos estranhos às composições (impurezas na mistura) que poderiam prejudicar as características desejadas.

\subsection{Caracterização da microdureza Vickers (HV)}

A análise da microdureza Vickers da superfície das amostras do compósito foram feitas utilizando o microdurômetro que pertence ao Laboratório de Metalografia do Departamento de Engenharia de Materiais e Metalurgia da PoliUSP. Foi feita avaliação usando o microdurômetro com sistema de carga de 25,0 gf $(98,07 \mathrm{mN})$ aplicada ao penetrador e microscópio acoplado com aumentos de 400X. A amostragem foi feita medindo a dureza em três diferentes pontos na superfície e três pontos na superfície do corte de secção da amostra definidos como pontos central, pontos mediano e pontos de borda. No penetrador do microdurômetro foi posicionado sobre os pontos definidos da amostra durante 15 segundos. Após procedimento de marcação das diagonais, o valor numérico de microdureza Vickers é mostrado no display digital. O teste de dureza Vickers é recomendado pelas Normas ASTM E 92 e NBR NM ISSO 6507 para obtenção de dados de resistência mecânica e dureza aplicáveis aos componentes sinterizados.

\subsection{Ensaios de atenuação da radiação}

Os ensaios experimentais de atenuação da radiação com colimação com feixe fino foram relizados no Laboratório de Estrutura da Matéria do Instituto de Física da USP (IFUSP). Para aquisição dos dados de atenuação da radiação pelas amostras selecionadas foi montado e configurada uma instrumentação composta de uma fonte, um detetor de radiação, um sistema amplificadorconversor AD com software aplicativo versão Windows. Os ensaios experimental foram realizados como ilustra o diagrama esquemático da figura 4.4.

Figura 4.4 Diagrama ilustrativo do sistema de aquisição de dados para os ensaios experimentais de atenuação da radiação. 


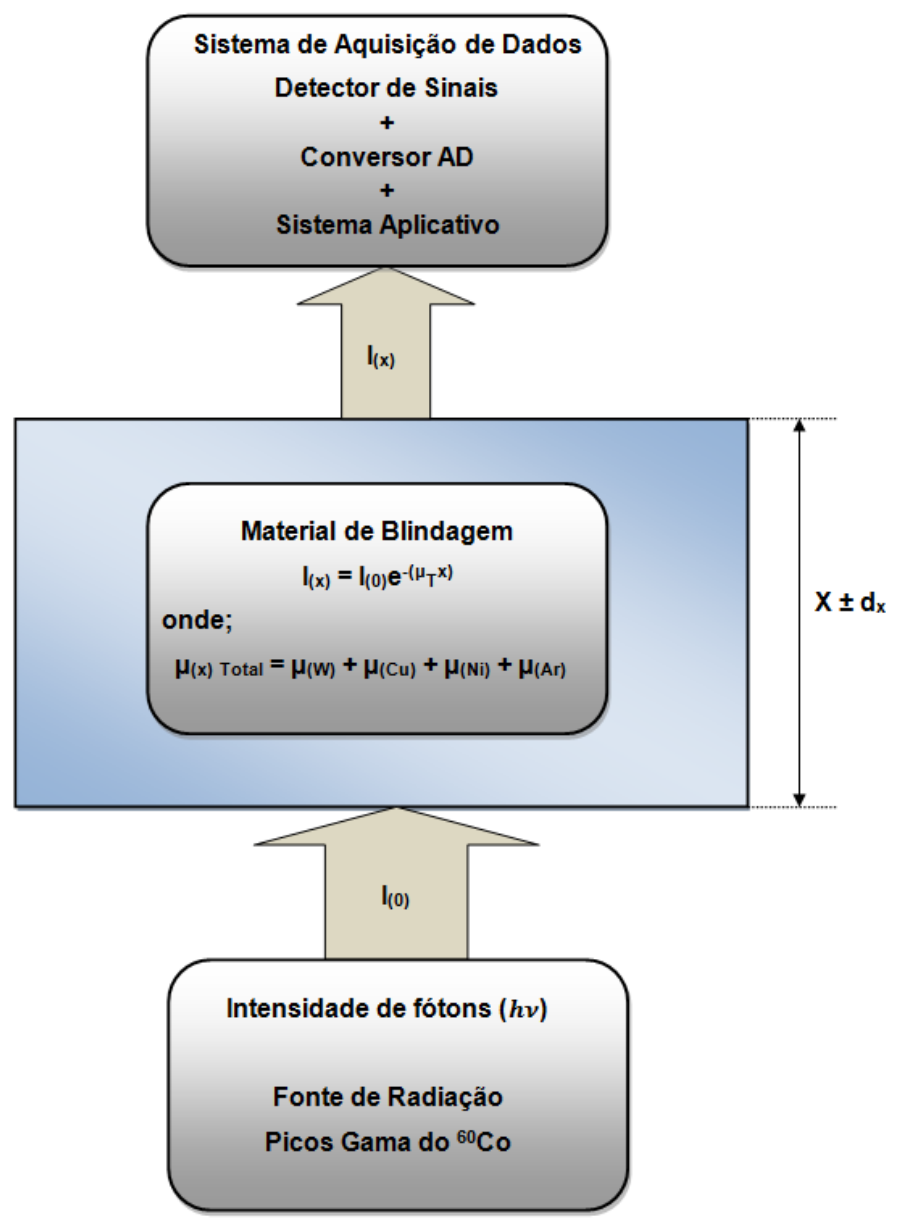

Fonte: Sinterização de Pós Compósitos do Sistema W-Cu; Tese de Doutoramento

Para os ensaios foram utilizados os equipamentos composto por fonte de radiação Cobalto-60 (Co-60; primeiro pico de energia em 1.137 keV, segundo pico de energia em $1.332 \mathrm{keV}$ ). Os ensaios experimentais de transmissão da radiação (atenuação) para determinar o coeficiente de atenuação em massa $(\mu / \rho)$ foram realizados por técnica de feixe fino.

As amostras utilizadas tiveram as dimensões de altura (espessura do material atenuador) ajustadas para a medida de $10 \pm 1 \mathrm{~mm}$, por desgaste com uso de série de lixas mantendo a uniformidade para os ensaios experimental. Para obter as medidas foi usado um paquímetro mecânico com precisão de 0,05 $\mathrm{mm}$ com auxílio do encosto interno.

Inicialmente foram usadas amostras certificadas do material tungstênio e chumbo como na obtenção de dados como atenuação referencial. As amostras de referência são compostas de chumbo maciço 99,9\%, dimensões 10,0 mm de altura x 5,45 mm de diâmetro e outra de tungstênio, também de 99,9\% de pureza, 
dimensões $10,0 \mathrm{~mm}$ de altura x 2,50 mm de diâmetro. Como procedimento do ensaio foi feita a calibração com a radiação de fundo (branco) e com amostras de material referência sob ação de atenuação do feixe por 30 minutos (1800 s) e a amostragem/contagem média de detetor com aproximadamente 15.000 eventos (contagens). O mesmo procedimento de ensaio experimental foi empregado para as amostras sinterizadas do sistema W-Cu, W-Ni e W-Cu-Ni.

\subsubsection{Colimador de feixe fino}

O ensaio de feixe fino (Narrow Beam Geometry - NBG) tem por objetivo restringir a área de radiação transmitida para a área central da superfície do detetor minimizando erros advindos de espalhamentos secundários. Para realização do ensaio foi necessário construir um colimador limitador para o feixe de fótons gama da fonte de cobalto-60 (Co-60). O colimador como ilustrado na figura 4.5 é composto de três partes que acondicionam a fonte e auxiliam no posicionamento das amostras.

\subsubsection{Sistema de aquisição de dados}

O sistema de aquisição de dados usado nos ensaios experimentais de atenuação da radiação foi configurado usando detetor de radiação Bricon 2M2/2, pastilhas de cobalto-60, fonte de alimentação DC Tectrol TCH-1500-2E, amplificador analógico de sinais Ortec modelo 442 com osciloscópio Insetek GW $60 \mathrm{MHz}$; conversor analógico-digital AD de 255 canais digitais. Os 255 canais digitais (28 bits nível) permitem a varredura de energia em passos digitais (discretizada) entre $1,0 \times 10^{-3} \mathrm{keV}$ e $1,8 \times 10^{3} \mathrm{keV}$. O desvio padrão da instrumentação foi avaliado em $15 \%$ decorrente do envelhecido da instrumentação, razão de não utilização de propagação. Um sistema aplicativo de software SW-Windows, desenvolvido no Laboratório de Estrutura da Matéria disponibiliza um relatório em forma de tabela contendo dados referente ao tempo, contagem de eventos por canal de energia (intensidade). A figura 4.6 ilustra o conjunto de equipamentos usado nos ensaios experimentais.

Figura 4.5 Imagem ilustrativa do colimador de fonte feixe fino: (a) detalhe da tampa porta amostra do colimador, (b) conjunto colimador montado, (c) amostra referência de tungstênio, (d) porta amostra do colimador, (e) parte superior do castelo do colimador, (f) parte inferior do castelo do colimado,r (g) detetor de radiação e (h) nicho e colimador. 

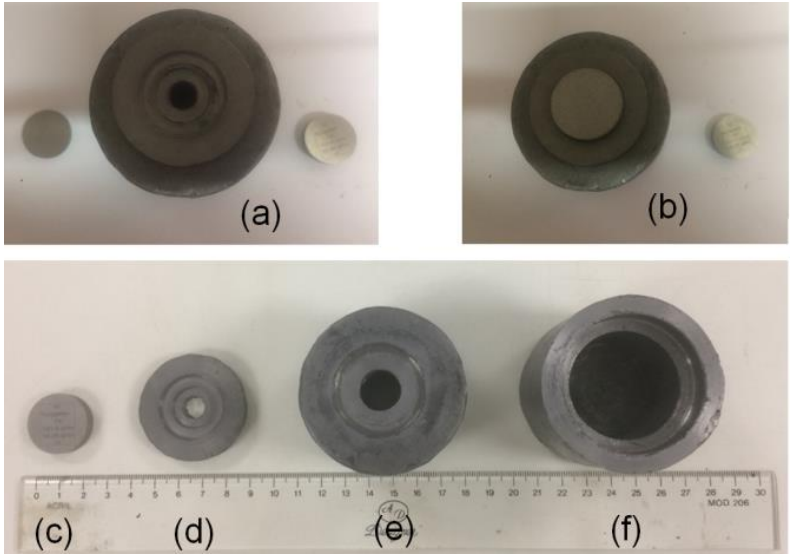

(c) (d)

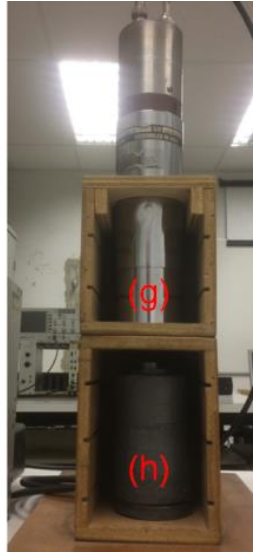

Fonte: fotografada pelo autor

Figura 4.6 Imagem ilustrativa da montagem do conjunto de equipamentos usado nos ensaio experimental.
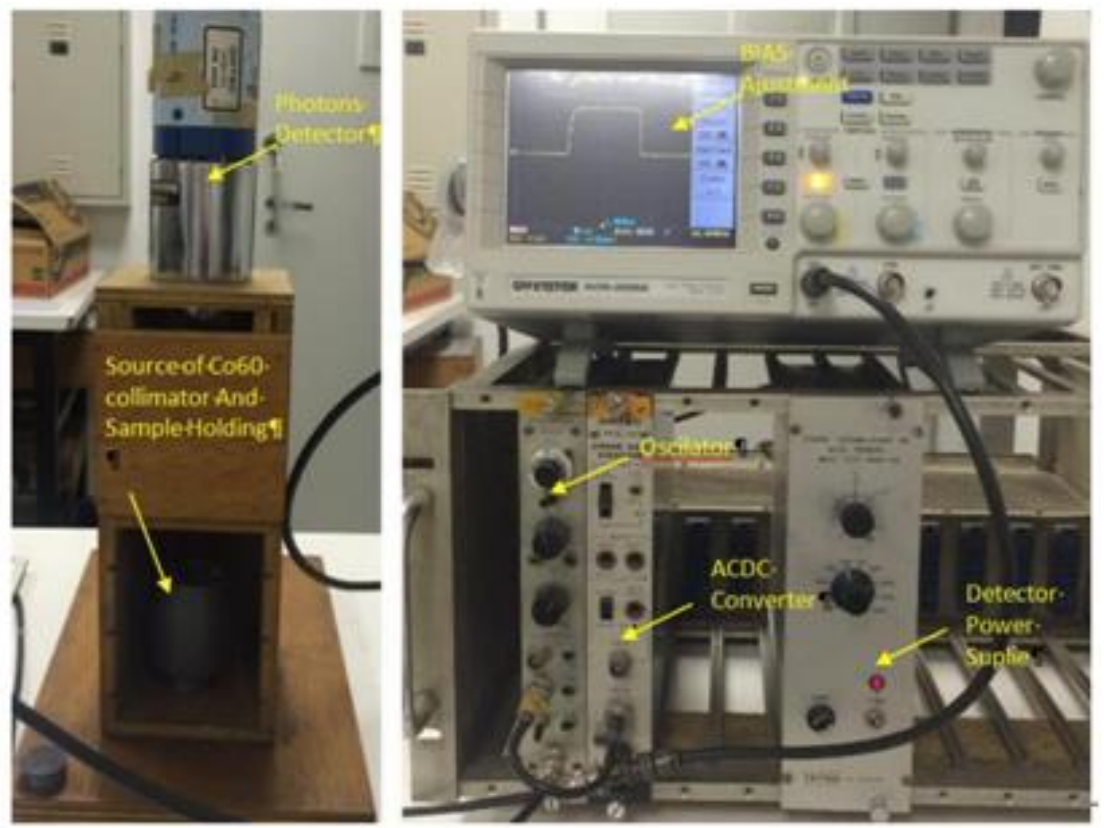

Foto: fotografada pelo autor 


\section{RESULTADOS E DISCUSSÃO}

\subsection{Características dos pós de partida}

\subsubsection{Peneiramento}

A tabela 5.1 apresenta o tamanho médio de partículas obtido por técnica de peneiramento dos pós de tungstênio, cobre e níquel como recebido e a tabela 5.2 apresenta o tamanho de partículas do pó, após tempo de moagem de 12, 24 e 36 horas.

Tabela 5.1 Determinação do tamanho de partículas por peneiramento como recebido.

\begin{tabular}{ll}
\hline $\begin{array}{ll}\text { Identificação dos pós } \\
\text { metálicos }\end{array}$ & $\begin{array}{l}\text { Tamanho de partícula médio como } \\
\text { recebido }(\mu \mathrm{m})\end{array}$ \\
\hline Tungstênio & 63,0 \\
\hline Cobre eletrolítico & 18,0 \\
\hline Cobre PAC & 10,0 \\
\hline Cobre PAM & 28,0 \\
\hline Fíquel & 37,0 \\
\cline { 2 - 2 } &
\end{tabular}

Fonte: criada pelo autor

Tabela 5.2 Determinação do tamanho de partículas por peneiramento depois de moído.

\begin{tabular}{llll}
\hline \multirow{2}{*}{$\begin{array}{l}\text { Identificação dos } \\
\text { pós metálicos }\end{array}$} & \multicolumn{3}{l}{$\begin{array}{l}\text { Tamanho de partícula médio após } \\
\text { moagem }(\mu \mathrm{m})\end{array}$} \\
\cline { 2 - 4 } & por $12 \mathrm{~h}$ & por $24 \mathrm{~h}$ & por $36 \mathrm{~h}$ \\
\hline Tungstênio & 59,0 & 54,0 & 46,0 \\
\hline Cobre eletrolítico & 16,0 & 15,0 & 14,0 \\
\hline Cobre PAC & 10,0 & 9,0 & 9,0 \\
\hline Cobre PAM & 25,0 & 22,0 & 20,0 \\
\hline Níquel & 35,0 & 30,0 & 29,0 \\
\hline
\end{tabular}

Fonte: criada pelo autor

Como ilustram as tabelas 5.1 e 5.2 pode-se estabelecer um comparativo dos valores para obter a eficiência em redução do tamanho médio dos particulados nos pós de metal por ação do moinho de bolas convencional. A técnica de peneiramento permite a separação e agrupamento por faixa determinados, de tamanhos de partículas e o resultado da comparação mostra média de redução de $27 \%$ no tamanho das partículas de tungstênio, 23\% para o cobre eletrolítico, $10 \%$ para o cobre PAC, $28 \%$ nos particulados do cobre PAM e 
$22 \%$ para os particulados de pó de níquel. Estes valores demosntram eficiência quantitativa na redução de tamanho de partícula por aplicação do moinho de esferas.

\subsubsection{Escoabilidade}

A tabela 5.3 apresenta como resultado os dados do teste de taxa de fluxo de escoabilidade (Flow tester). Os cálculos de densidade solta e batida foram obtidos para os pós como recebido e após tempo de moagem de 36 horas como apresentado na tabela 5.4 .

Tabela 5.3 Resultado da análise de taxa de fluxo para os pós de tungstênio, cobre e níquel como recebido e após 36 horas de ação de moagem.

\begin{tabular}{lll}
\hline $\begin{array}{l}\text { Identificação dos pós } \\
\text { metálicos }\end{array}$ & $\begin{array}{l}\text { Taxa média de fluxo } \\
\text { dos pós como recebido } \\
\left(\mathrm{g} \cdot \mathrm{s}^{-1}\right)\end{array}$ & $\begin{array}{l}\text { Taxa média de fluxo } \\
\text { dos pós após } 36 \text { horas } \\
\text { de moagem }\left(\mathrm{g} \cdot \mathrm{s}^{-1}\right)\end{array}$ \\
\hline Tungstênio & 1,20 & 1,23 \\
\hline Cobre eletrolítico & 0,96 & 0,89 \\
\hline Cobre PAC & 2,24 & 2,27 \\
\hline Cobre PAM & 2,30 & 2,37 \\
\hline Níquel & 1,21 & 1,23 \\
\hline Fonte: criada pelo autor &
\end{tabular}

Os dados obtidos relativos à escoabilidade, densidade aparente e batida para os pós de tungstênio e níquel não puderam ser comparados, devido a falta de dados publicados nos relatórios técnicos da Sigma-Aldrich e Novamet. O boletim técnico fornecido pela Metalpó para o cobre PAC informa densidade aparente e de minimo $=2,50\left(\mathrm{~g} \cdot \mathrm{cm}^{-3}\right)$ e máximo $=3,0\left(\mathrm{~g} \cdot \mathrm{cm}^{-3}\right)$ e não informa a taxa de escoamento. Para o cobre PAM o boletim informa densidade aparente e de minimo $=2,20\left(\mathrm{~g} \cdot \mathrm{cm}^{-3}\right)$ e máximo $=3,0\left(\mathrm{~g} \cdot \mathrm{cm}^{-3}\right)$ e para a taxa de escoamento de $50 \mathrm{~g}$ de pó em $34 \mathrm{~s}$, resultando em taxa de escoamento de 1,47 g.s ${ }^{-1}$.

Tabela 5.4 Valores obtido para densidade aparente (solta) e batida (tapped density) os pós de tungstênio, cobre e níquel como recebido.

\begin{tabular}{llll}
\hline $\begin{array}{l}\text { Identificação dos pós } \\
\text { metálicos }\end{array}$ & $\begin{array}{l}\text { Densidade aparente } \\
\text { dos pos como recebido } \\
\left(\mathrm{g} \cdot \mathrm{cm}^{-3}\right)\end{array}$ & $\begin{array}{l}\text { Densidade batida dos } \\
\text { pos como recebido } \\
\left(\mathrm{g} \cdot \mathrm{cm}^{-3}\right)\end{array}$ \\
\hline Tungstênio & 6,85 & 8,62 \\
\hline Cobre eletrolítico & 3,11 & 3,18 \\
\hline
\end{tabular}




\begin{tabular}{lll}
\hline Cobre PAC & 3,33 & 3,85 \\
\hline Cobre PAM & 3,45 & 4,17 \\
\hline Níquel & 4,76 & 5,67 \\
\hline
\end{tabular}

Fonte: criada pelo autor

É possível observar que os valores de densidade batida para o pó de cobre eletrolítico apresentou pequena alteração, que pode ser explicada pelo formato dentritico das partículas. Segundo German [63], a forma dos particulados influencia na taxa de compactação, com consequências na fase da sinterização para qualidade do produto. A forma dentritica por ser irregular causa maior distanciamento entre os particulados do pó de cobre eletrolítico. Esta característica é um fator complicador para o uso do cobre eletrolítico como metal de composição para a compactação e consequente sinterização com fase líquida devido a maior probabilidade de formação de poros [135]. Os pós de tungstênio, cobre PAC, cobre PAM e níquel alcançaram, em média, $75 \%$ de densificação relativa para o ensaio de densidade aparente.

\subsubsection{Granulometria}

A tabela 5.5 apresenta os resultados da análise de granulométrica de distribuição do tamanho de partículas no pó como recebido. Foi utilizado a técnica da dispersão de feixe LASER (equipamento CILAS) para obter as informações e produzir a tabela 5.6 que apresenta os resultados da análise granulométrica dos pós depois de moído no tempo de 36 horas.

Tabela 5.5 Resultado da análise granulometria (CILAS) do tamanho de partículas dos pós de tungstênio, cobre e níquel como recebido.

\begin{tabular}{ll}
\hline $\begin{array}{l}\text { Identificação dos pós } \\
\text { metálicos }\end{array}$ & $\begin{array}{l}\text { Tamanho de partícula } \\
\text { médio como recebido } \\
(\mu \mathrm{m})\end{array}$ \\
\cline { 2 - 2 } & $\begin{array}{l}\text { Tungstênio } \\
\text { Cobre eletrolítico }\end{array}$ \\
\hline Cobre PAC & 23,0 \\
\hline Cobre PAM & 13,0 \\
\hline Fíquel & 25,0 \\
\hline
\end{tabular}

Tabela 5.6 Resultado da análise granulometria (CILAS) do tamanho de partículas dos pós de tungstênio, cobre e após 36 horas de moagem.

\begin{tabular}{lll}
\hline $\begin{array}{l}\text { Identificação dos pós } \\
\text { metálicos }\end{array}$ & $\begin{array}{l}\text { Tamanho de partícula após } \\
\text { moagem por } 36 \mathrm{~h}(\mu \mathrm{m})\end{array}$ \\
\hline
\end{tabular}


Fonte: criada pelo autor

\begin{tabular}{lllll}
\hline & $\mathrm{D}_{10}$ & $\mathrm{D}_{50}$ & $\mathrm{D}_{90}$ & D médio \\
\hline Tungstênio & 0,3 & 35,2 & 67,1 & 48,4 \\
\hline Cobre eletrolítico & 0,7 & 16,6 & 42,1 & 19,2 \\
\hline Cobre PAC & 9,2 & 29,7 & 54,6 & 31,0 \\
\hline Cobre PAM & 8,0 & 23,6 & 47,1 & 26,4 \\
\hline Níquel & 2,3 & 13,5 & 24,1 & 14,4 \\
\hline da pelo autor & & & &
\end{tabular}

Ao comparar os valores de tamanho das partículas dos pós como recebido pela técnica do peneiramento com a técnica de granulometria CILAS, nota-se forte convergência nos valores obtidos para os pós de tungstênio. Ao comparar os valores médio para as partículas após ação de 36 horas de moagem entre a técnica de peneiramento (tabela 5.2) e granulometria CILAS (tabela 5.6) é observado diferença significativa (superior a $3 x$ ) entre os valores mensurados $e$ de granulometria ( $\left.D_{\text {médio }}\right)$ para os particulados do cobre PAM e para o níquel. Essa ocorrência pode ser justificada por divergência entre os valores de mínimo $\left(D_{10}\right)$, valores $\left(D_{90}\right)$ e os valores $D_{\text {médio }}$ para os pós de cobre PAC e níquel. As duas técnicas podem ser empregadas como complementares na obtenção dos valores médio para tamanho de partícula. A técnica de granulometria apresenta como vantagem a informação da distribuição do tamanho de partículas do pó. Esta informação é importante porque segundo Kuhn [75] a distribuição das partículas segue a forma gauseana com menor amplitude relativa de FWHM (alargamento da função).

Na figura 5.1 é apresentado o gráfico obtido da análise granulométrica do tungstênio como recebido e na figura 5.2 é apresentado o gráfico do pó de tungstênio após a ação de moagem por tempo de $36 \mathrm{~h}$.

Figura 5.1 Gráfico de granulométrica (CILAS) para os pós de tungstênio como recebido. 


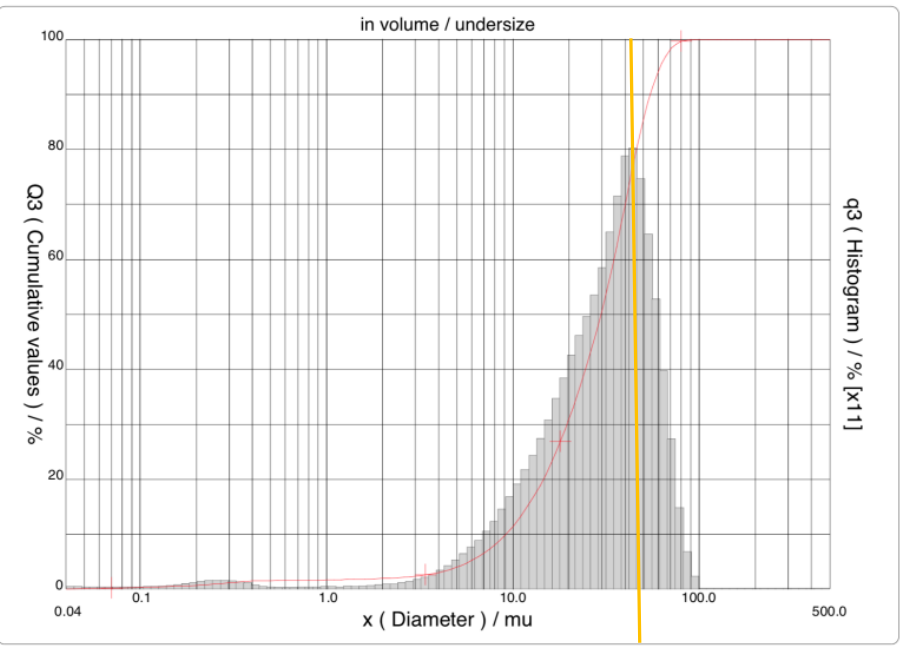

Fonte: criada pelo autor

Figura 5.2 Gráfico de granulométrica (CILAS) para o pó de tungstênio após 36 h de moagem.

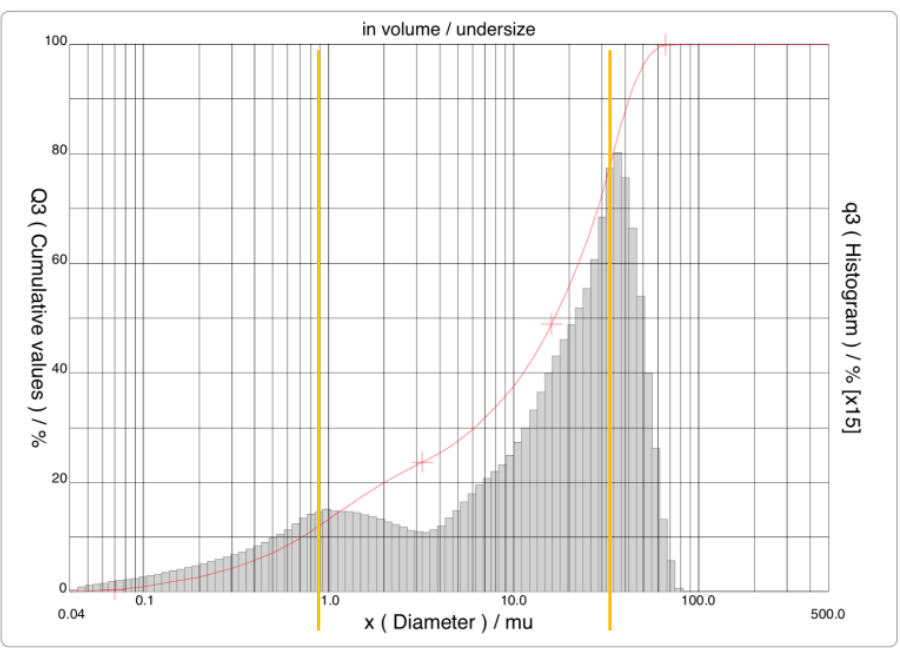

Fonte: criada pelo autor

Da análise, por comparação entre os gráficos do pó de tungstênio, como recebido (figuras 5.1) e do pó de tungstênio após $36 \mathrm{~h}$ de moagem (figura 5.2) demostra mudanças na distribuição do tamanho de partículas. Na figura 5.1, a distribuição tem comportamento mono modal enquanto na figura 5.2 o comportamento após moagem mudou, como esperado, para bimodal representando maior diversidade na distribuição do tamanho de partículas. $\mathrm{Na}$ figura 5.3 é apresentado o gráfico obtido da análise granulométrica do pó de cobre eletrolítico como recebido e na figura 5.4 é apresentado o gráfico do pó de cobre eletrolítico, após ação de moagem de 36 horas. 
Figura 5.3 Gráfico de granulométrica (CILAS) para os pós de cobre eletrolítico como recebido.

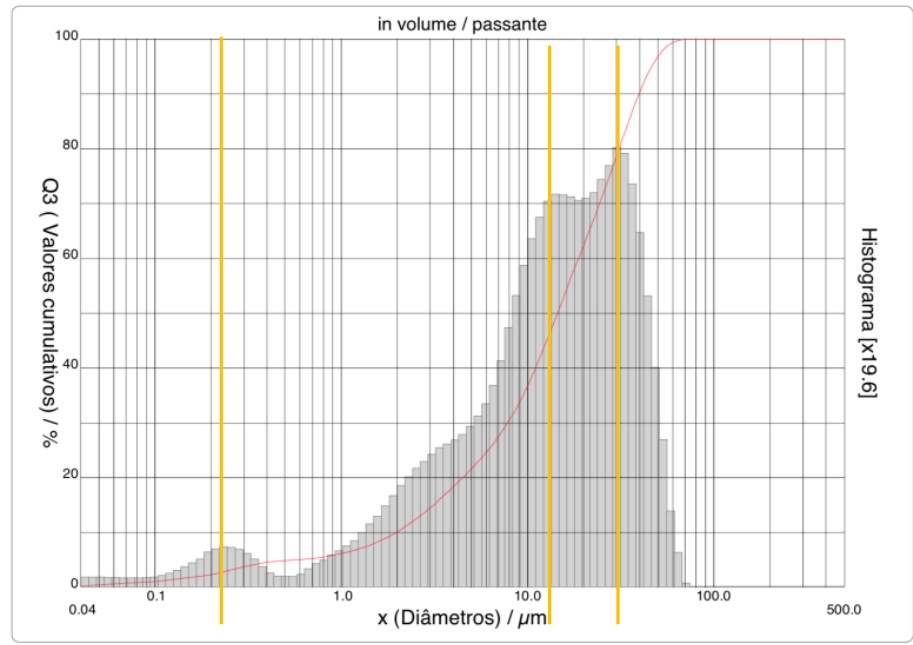

Fonte: criada pelo autor

Figura 5.4 Gráfico de granulométrica (CILAS) para os pós de cobre eletrolítico após moagem de $36 \mathrm{~h}$.

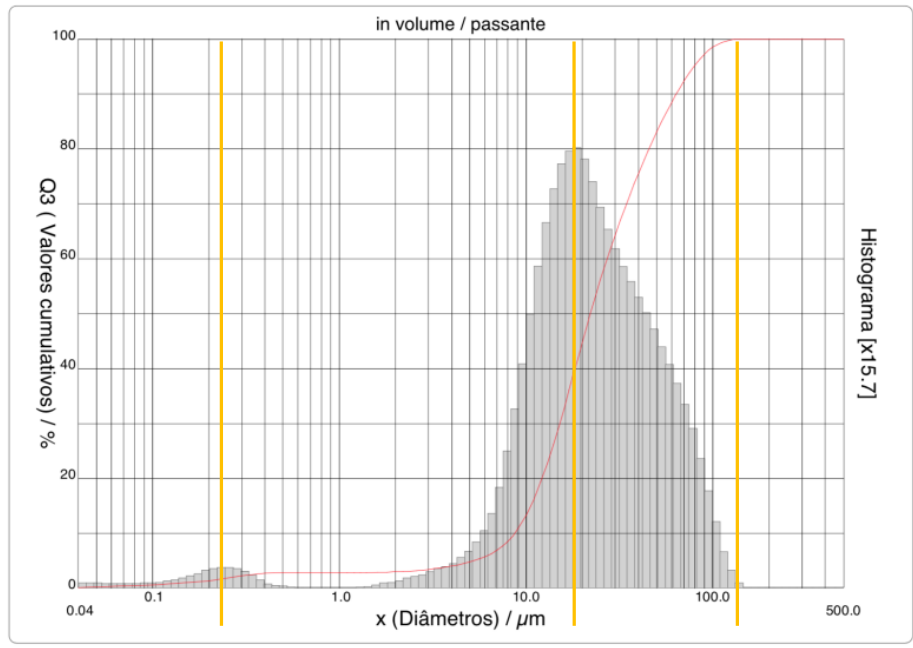

Fonte: criada pelo autor

Comparando os gráficos do pó de cobre eletrolítico como recebido (figuras 5.2) e do pó de cobre eletrolítico após $36 \mathrm{~h}$ de moagem (figura 5.3) é possível observar redução de tamanho médio das partículas de $24 \mu \mathrm{m}$ para $18 \mu \mathrm{m}$. O comportamento na distribuição, inicialmente com três picos, passou a mono modal com a indicação de junção de partículas menores, formando agregados que superaram os valores iniciais de $80 \mu \mathrm{m}$, apresentando uma pequena parcela de partículas com tamanho superior a $100 \mu \mathrm{m}$.

Na figura 5.5 é apresentado o gráfico obtido da análise granulométrica do 
pó de cobre PAC como recebido e na figura 5.6 é apresentado o gráfico do pó de cobre PAC, após ação de moagem de $36 \mathrm{~h}$.

Figura 5.5 Gráfico de granulométrica (CILAS) para os pós de cobre PAC como recebido.

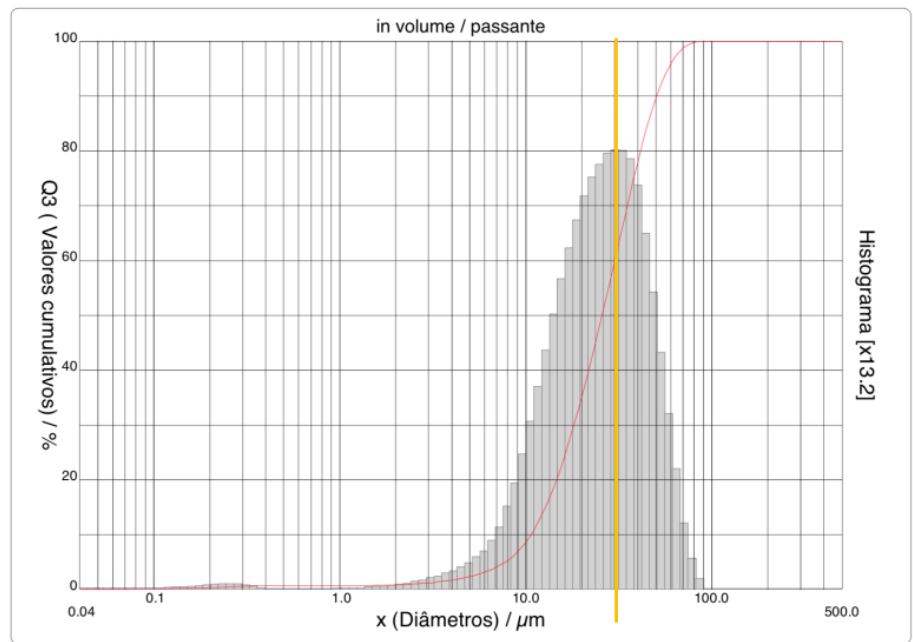

Fonte: criada pelo autor

Figura 5.6 Gráfico de granulométrica (CILAS) para os pós de cobre PAC após moagem de 36 horas.

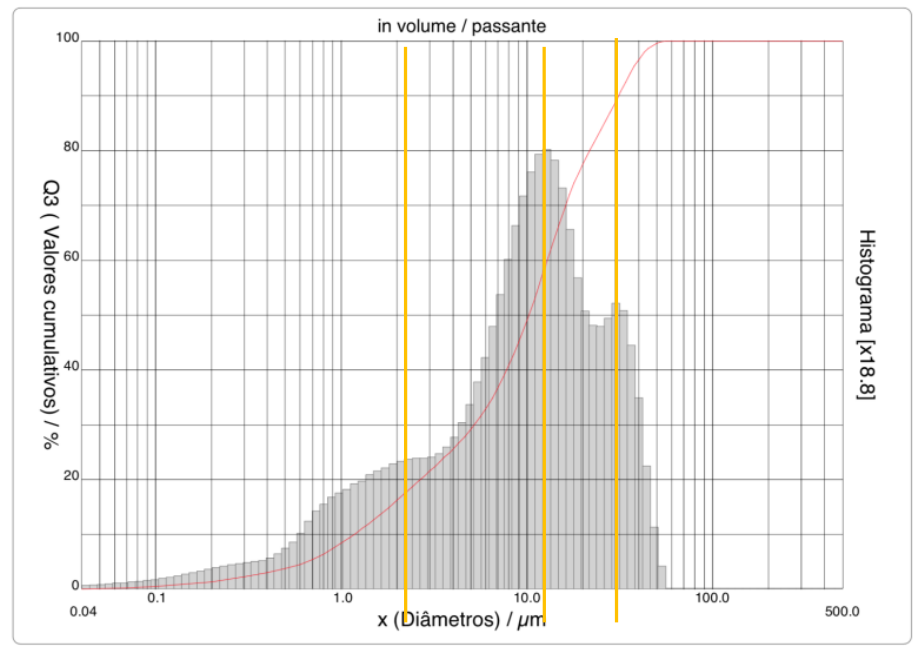

Fonte: criada pelo autor

Da comparação entre os gráficos do pó de cobre PAC como recebido (figuras 5.5) mono modal e do pó de cobre PAC após 36 h de moagem (figura 5.6) trimodal é possível observar o deslocamento do pico do tamanho máximo na distribuição das partículas de $30 \mu \mathrm{m}$ para $14 \mu \mathrm{m}$. Por média, pode-se obter o tamanho de $8 \mu \mathrm{m}$ para o pó após moagem, o que reduz e diversifica a distribuição no tamanho de partículas. 
Na figura 5.7 é apresentado o gráfico obtido da análise granulométrica do pó de cobre PAM como recebido e na figura 5.8 é apresentado o gráfico do pó de cobre PAM após a ação de moagem por tempo de $36 \mathrm{~h}$.

Figura 5.7 Gráfico de granulometria (CILAS) para o pó de cobre PAM como recebido.

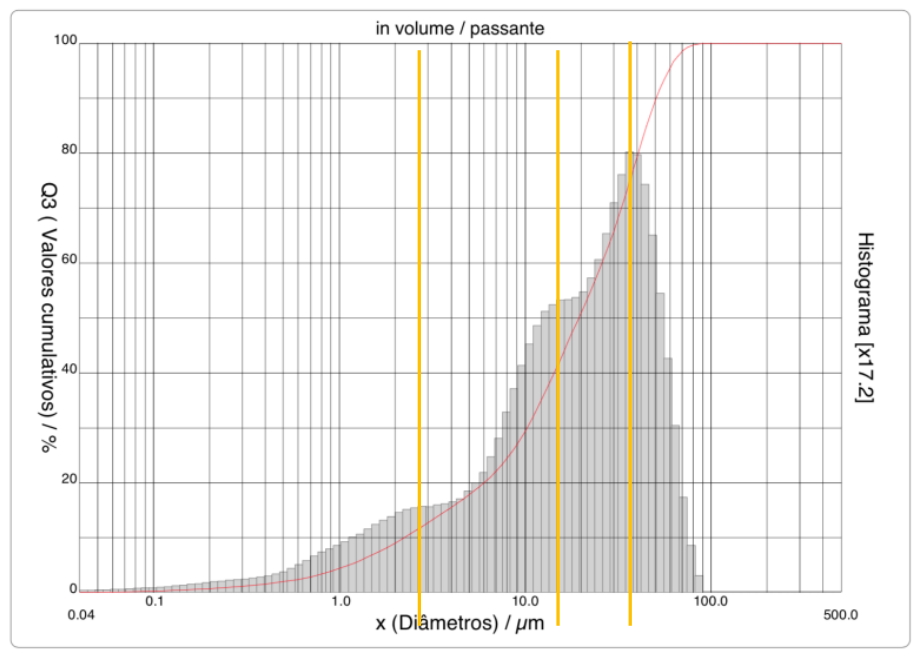

Fonte: criada pelo autor

Figura 5.8 Gráfico de granulometria (CILAS) do pó de cobre PAM após moagem de $36 \mathrm{~h}$.

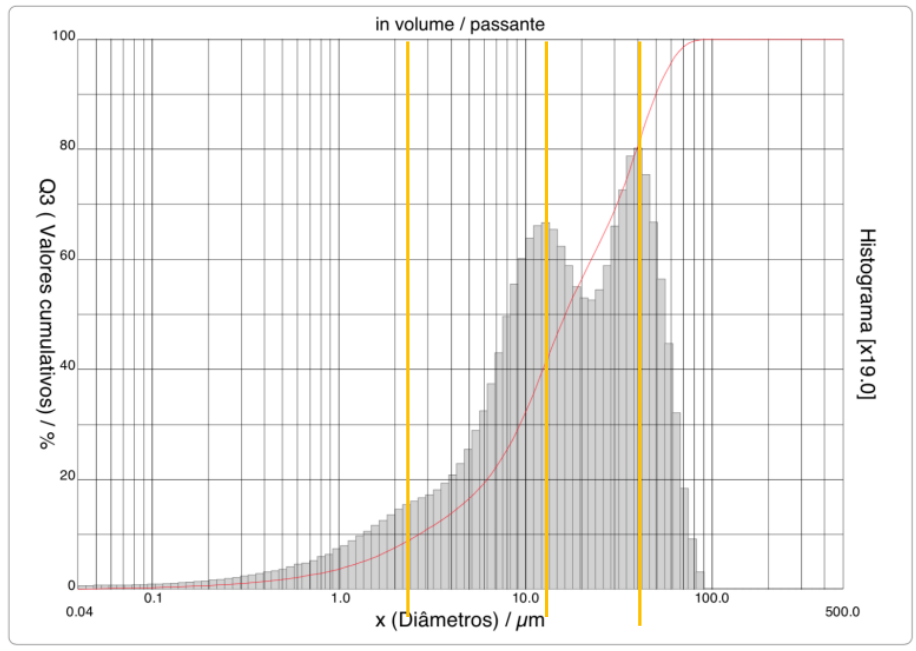

Fonte: criada pelo autor

Da comparação entre os gráficos das figuras 5.7 e 5.8 pode ser observado manutenção do comportamento na distribuição do tamanho de partículas, porém ocorreu um deslocamento de volume das partículas de tamanho médio de $40 \mu \mathrm{m}$ para tamanho médio de $16 \mu \mathrm{m}$, indicando redução de tamanho por ação de moagem.

Na figura 5.9 é apresentado o gráfico obtido da análise granulométrica do 
pó de níquel como recebido e na figura 5.10 é apresentado o gráfico composição dos pó de níquel, após a ação de moagem por tempo de $36 \mathrm{~h}$.

Figura 5.9 Gráfico de granulometria (CILAS) para o pó de níquel como recebido.

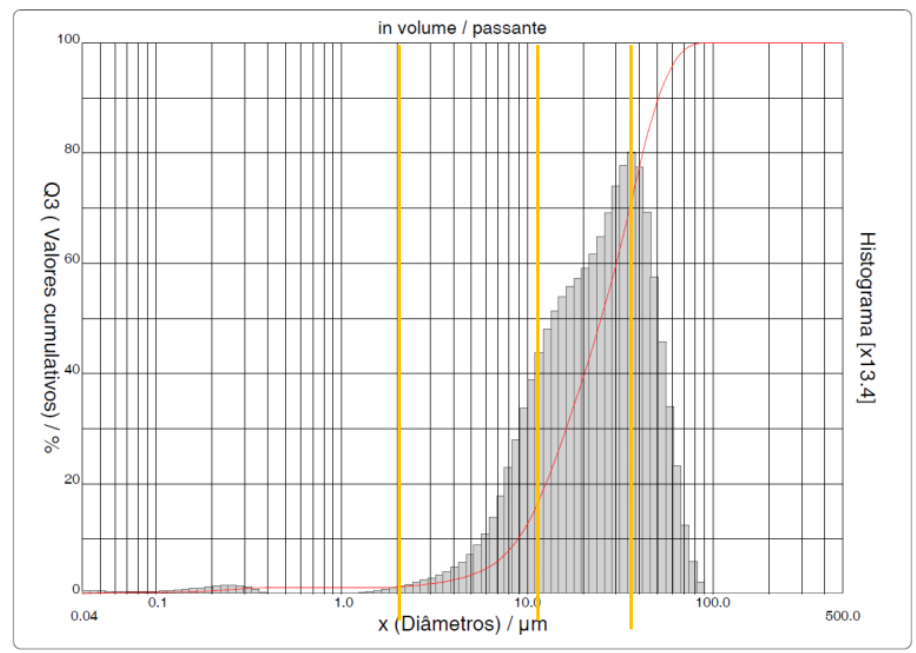

Fonte: criada pelo autor

Figura 5.10 Gráfico de granulometria (CILAS) para a composição de pós Niquel após moagem de $36 \mathrm{~h}$.

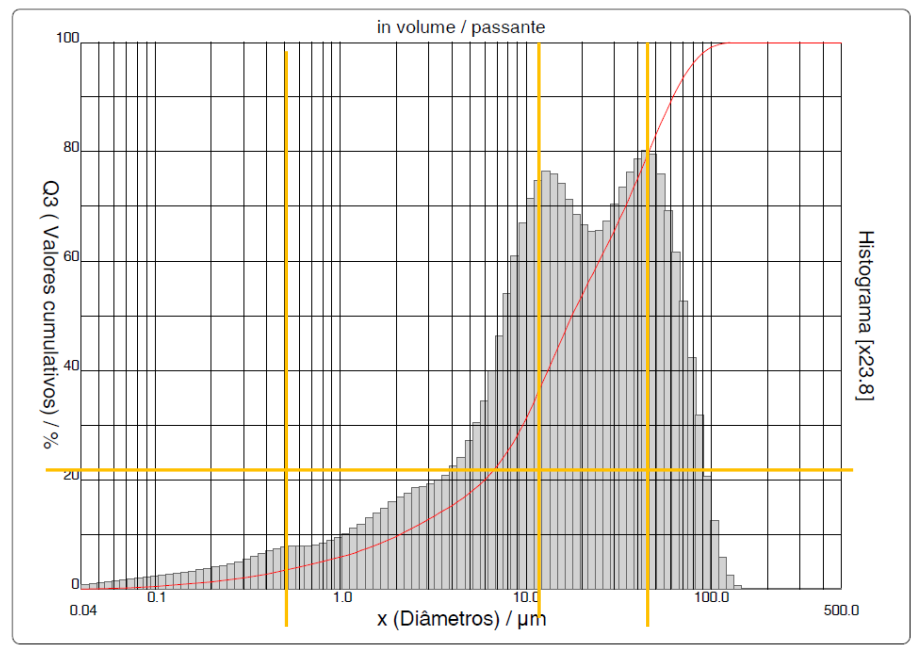

Fonte: criada pelo autor

O comportamento do metal pó níquel foi semelhante ao do cobre PAM. Ao comparar os gráficos das figuras 5.9 e 5.10 pode ser observado, na distribuição do tamanho de partículas, que ocorreu um deslocamento no volume de partículas (como recebido) de tamanho médio de $45 \mu \mathrm{m}$ para tamanho médio de $14 \mu \mathrm{m}$ indicando redução de tamanho por ação de moagem. Permanece a característica tri-modal após $36 \mathrm{~h}$ de moagem. A característica da distribuição mostra maior valor acumulativo nos $20 \%$. 
A figura FIG. 5.11 mostra o efeito de redução de tamanho após moagem em tempos de 12 h, 24 h e 36 h em relação aos pós como recebido.

Figura 5.11 Distribuição do tamanho de partícula dos pós metálicos como informado, como recebido e após $12 \mathrm{~h}, 24 \mathrm{~h}$ e $36 \mathrm{~h}$ de moagem.

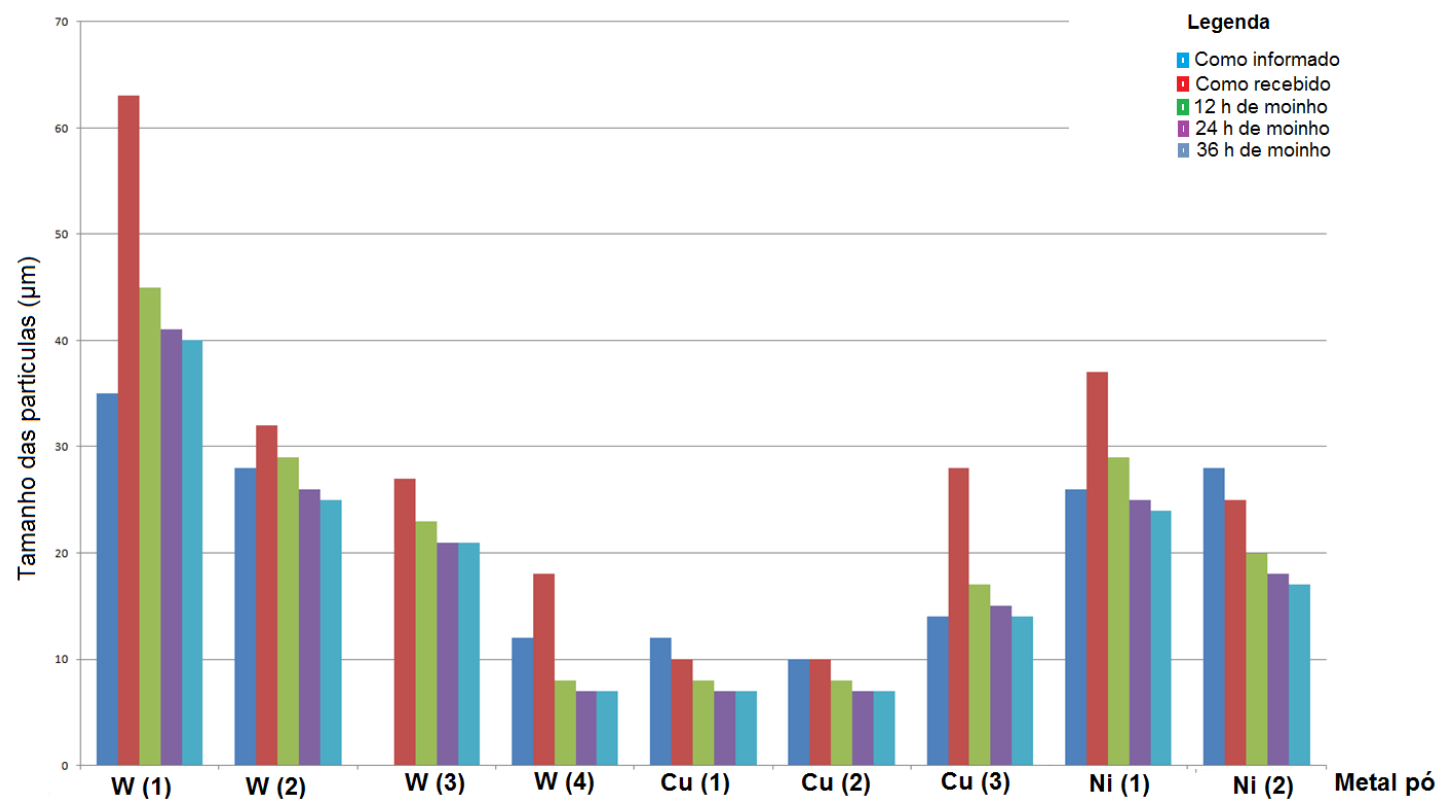

Fonte: criada pelo autor

O gráfico da figura 5.11 apresenta a comparação dos valores, informando em boletins técnicos para o tamanho das partículas dos pós-metálicos, adquiridos com os valores obtidos pelas técnicas de peneiramento e de granulometria dos pós como recebido pode ser observado diferenças na faixa de $30 \%$ a menor das medidas informadas em relação aos valores como recebido. Da análise sobre a eficiência de trituração por ação do uso de técnica de moagem em moinho de bolas convencional (tempo de $12 \mathrm{~h}, 24 \mathrm{~h}$ e $36 \mathrm{~h}$ ) pode-se concluir que houve redução do tamanho das partículas de todos os pós. Por granulometria, o gráfico de 36 horas de moagem para o pó de cobre eletrolítico apresentou comportamento distinto de provável união de partículas em blocos, por que apareceu partículas de tamanho maior que $100 \mu \mathrm{m}$. Pela técnica de peneiramento foi observado redução de $25 \%$, em média no tamanho de partículas após a moagem de 36 horas.

Pela técnica de granulometria (CILAS) a análise do tamanho de partículas mostra e confirma a redução do tamanho médio das partículas dos pós-metálicos e adicionalmente permite investigar a distribuição de tamanhos de partículas resultante após a moagem. Os relatórios fornecidos na forma de gráficos pelo 
sistema CILAS mostraram informações sobre a distribuição do tamanho das partículas nos pós como recebido e após moagem. As informações demostraram a influência e eficiência do moinho de bolas convencional ,resultando na redução do tamanho das partículas. Segundo os autores Smithells [61], German [65] e Costa [71] argumentam que a redução no tamanho das partículas não é o único fator a influenciar na compactação, mas a distribuição relativa dos tamanhos na composição dos pós quando aplicados para a obtenção de um compactado deverá influenciar na densificação resultante.

\subsubsection{Fluorescência de raios- $X$}

A tabela 5.7 apresenta como resultado os dados do relatório de análise da composição química feita por fluorescência de raios $X$ para os pós como recebido. Dos pós analisados foi observado divergências entre a composição informada e a composição como recebido para o tungstênio W (1) e W (2). Os valores de pureza informados foram de 99,8\% e 99,9\% respectivamente. Os valores de pureza obtido para os pós de tungstênio W (1) e W (2) como recebido foram $78,5663 \%$ e $97,9678 \%$.

Para o pó de tungstênio W (1), o valor de de pureza foi superior a $27 \%$ de outros elementos diferente do tungstênio. Os elementos molibdênio (Mo), tântalo (Ta) e alumínio (Al) aparecem na composição com 12,7799\%, 8,1800\% e $0,1528 \%$ respectivamente. As amostras para o sistema $\mathrm{W}-\mathrm{Cu}$ e W-Ni que utilizaram do pó de tungstênio $W$ (1) na preparação de suas composições apresentaram problemas de fissuras de relaxamento (spring-back) durante o processo de compactação e problemas de severa oxidação durante o processo de sinterização.

De acordo com Partington [86] e Fehlner [89] que estudaram os mecanismos de oxidação de diversos metais à baixas temperaturas e Habainy [52] que investigou a oxidação do tungstênio e compósitos à baixas temperaturas (intervalos $400{ }^{\circ} \mathrm{C}$ e $900{ }^{\circ} \mathrm{C}$ ) indicam que a reatividade ao oxigênio tende a variar entre metais elementares e metais, com diferente teor de outros elementos em composição. Nestes estudos sobre a cinética de oxidação do tungstênio,o o diagrama estrutural do sistema W-O mostra que a natureza de oxidação do tungstênio tem relação com a pressão e também que outros fatores como a constituição do metal tem substancial importância nas reações do tungstênio com 
o oxigênio [132,134,136]. Acrescetam que mesmo em temperatura ambiente (20 ${ }^{0} \mathrm{C}$ ) pode ser observada a formação de um filme superficial com espessura aproximada de $60 \AA$ 


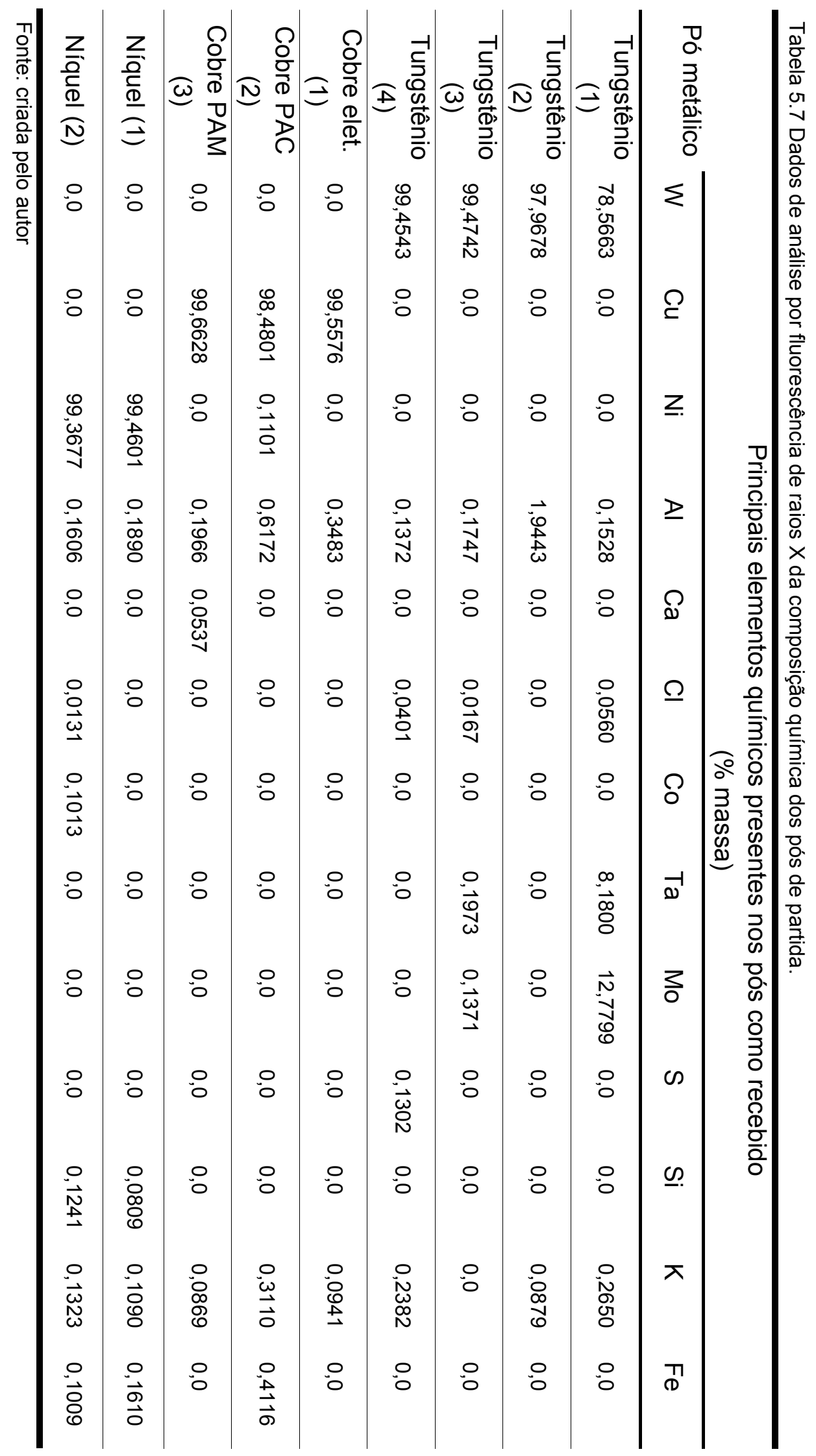


de óxido sobre o metal puro.

\subsubsection{Análise morfológica}

$\mathrm{Na}$ figura 5.12 é apresentada a micrografia do pó de tungstênio como recebido, onde é possível notar a forma poligonal das partículas e a variação na distribuição do tamanho de partículas no pó. Na figura 5.13 é possível notar a formação de numerosos aglomerados de partículas do pó de tungstênio de tamanho médio inferior a $10 \mu \mathrm{m}[54,138]$. O tamanho das partículas do pó de tungstênio associado a sua dureza dificulta a fluência do pó, resultando em menor taxa de empacotamento no processo de compactação a baixas pressões, isto pode ser explicado pela dificuldade de escoamento e mobilidade das partículas na cavidade da matriz $[53,57]$.

Figura 5.12 Micrografia MEV mostrando a distribuição do tamanho de partícula para o pó de tungstênio como recebido.

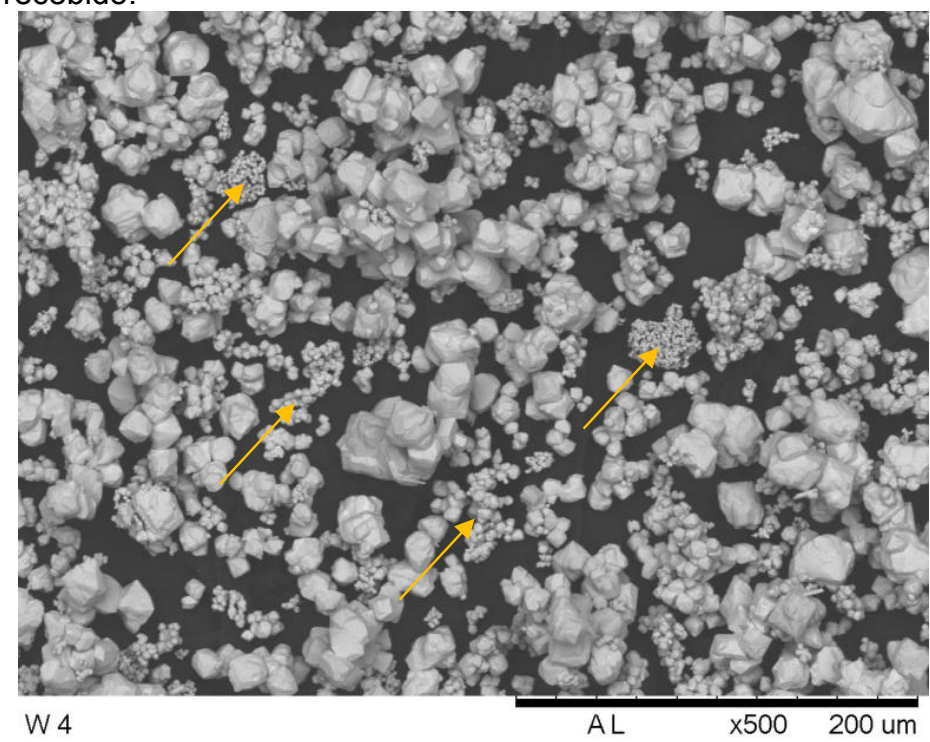

Fonte: criada pelo autor

Na micrografia da figura 5.13 é apresentado como destaque a formação de aglomerados de particulados de tungstênio com diâmetros inferiores a $10 \mu \mathrm{m}$ (a) e é possível destacar a forma poligonal de partículas no pó de tungstênio como recebido (b).

Figura 5.13 Micrografia MEV detalhando tamanho forma e formação de aglomerados de partículas para o pó de tungstênio como recebido. 


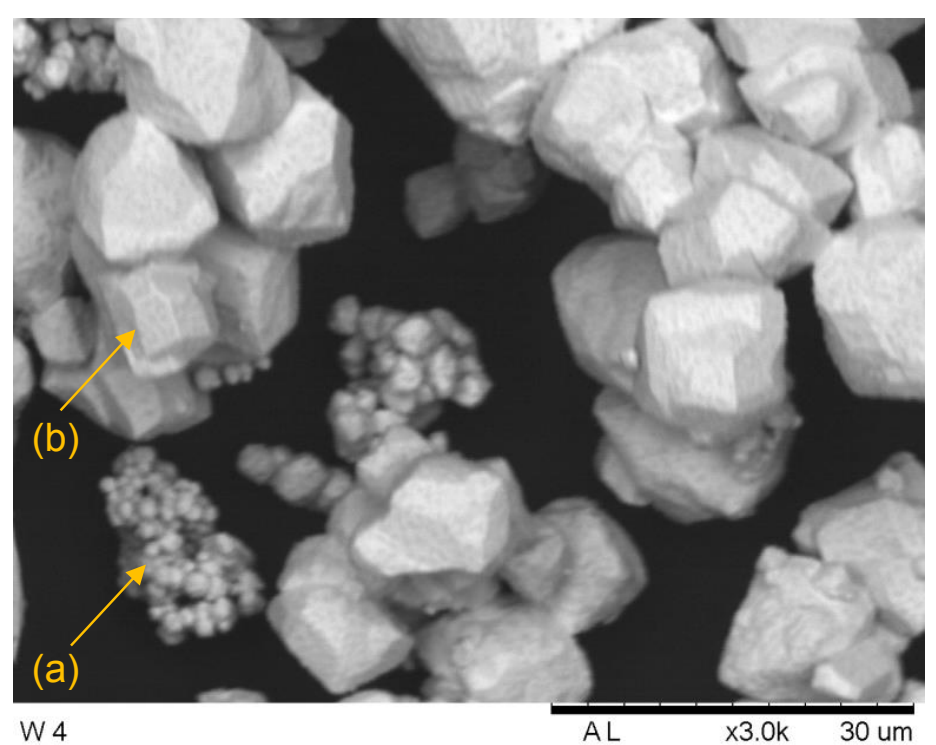

Fonte: criada pelo autor

A micrografia da figura 5.14 mostra a distribuição do tamanho de partículas para o pó de tungstênio após a ação de moagem por 36 horas. Em destaque (a) é possível observar as mudanças na forma (poligonal) aproximando-se de esférica de conjuntos de partículas irregular, (b) e partículas de diâmetro inferior a $10 \mu \mathrm{m}$ (c) resultante da fratura superfícial das partículas maiores do pó de tungstênio.

Figura 5.14 Micrografia MEV mostra o tamanho de partículas para o pó de tungstênio processado em moagem de $36 \mathrm{~h}$.

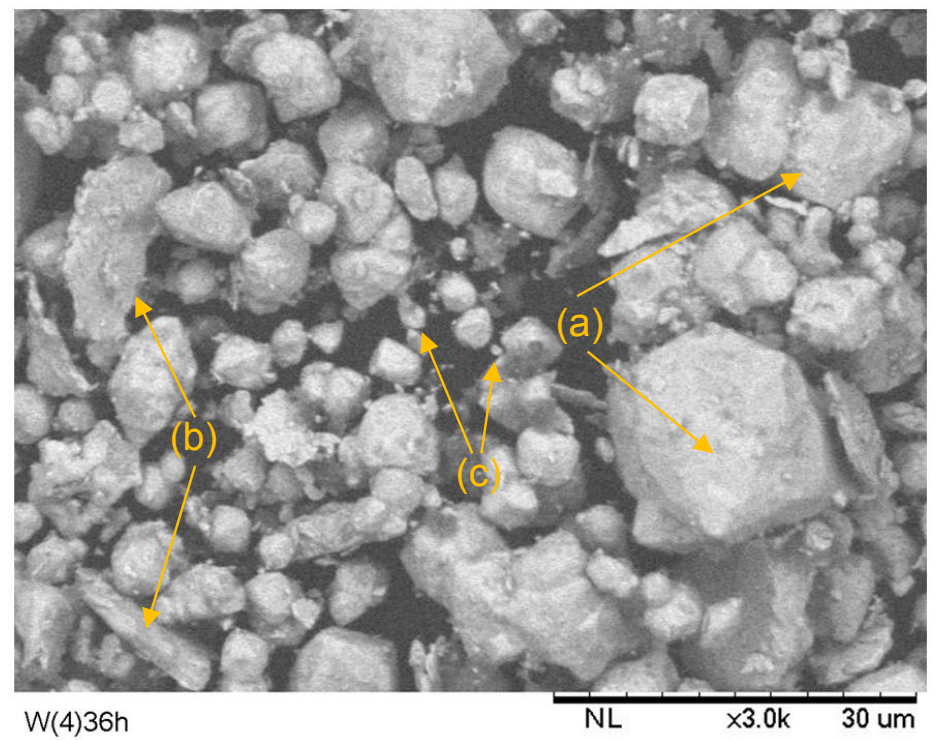

Fonte: criada pelo autor

Na figura 5.15 é apresentada a micrografia do pó cobre eletrolítico onde é 
possível notar a variação na distribuição de tamanho dos particulados e na figura 5.16 destaca-se a forma dendrítica das partículas (a). Segundo German [75], o tamanho médio das partículas do pó é de $30 \mu \mathrm{m}$, sendo da mesma ordem de grandeza quando comparado aos particulados do pó de tungstênio, fato que poderá representar dificuldades de densificação no processo de compactação.

Figura 5.15 Micrografia MEV mostra a variação na distribuição do tamanho de partículas para o pó de cobre eletrolítico como recebido.

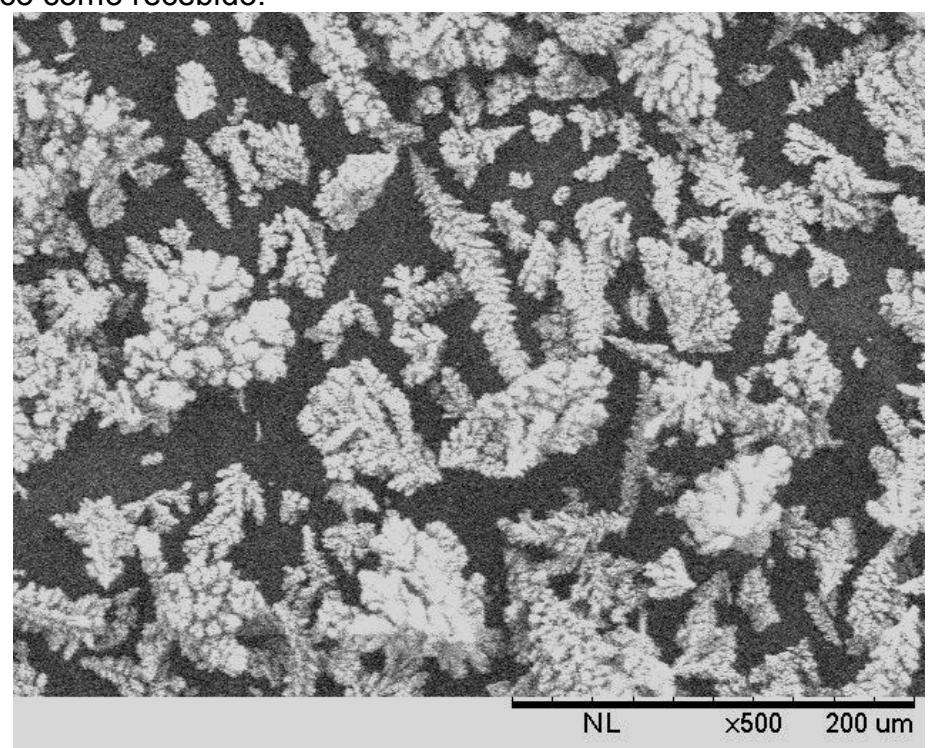

Fonte: criada pelo autor

Figura 5.16 Micrografia MEV mostra a forma dendrítica das partículas do pó de cobre eletrolítico como recebido.

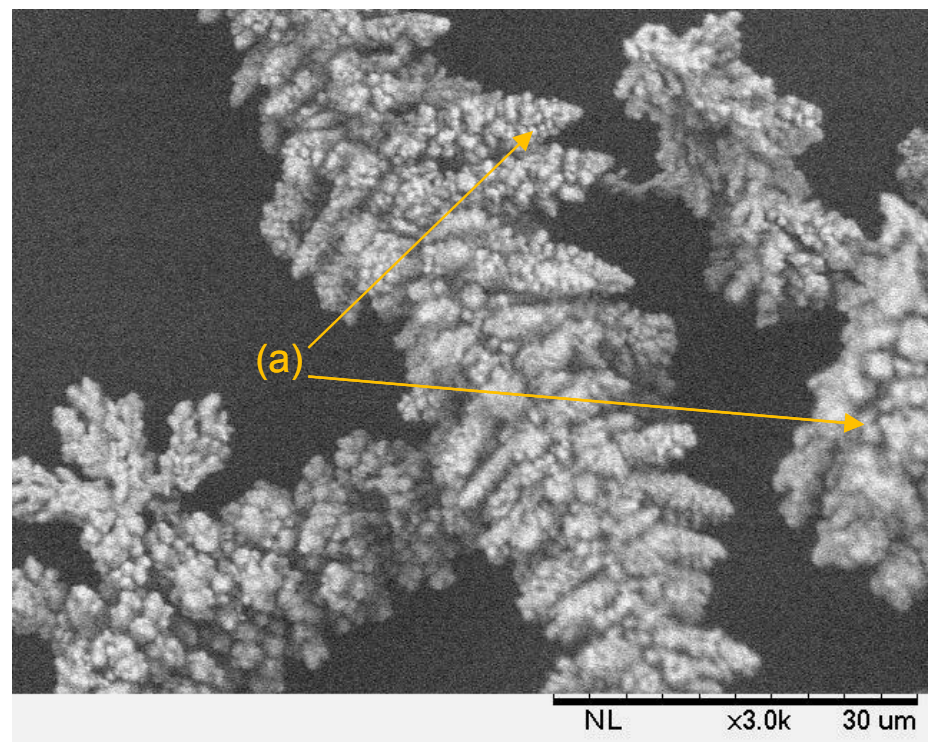

Fonte: criada pelo autor

A figura 5.17 mostra a micrografia das partículas de cobre eletrolítico após 36 horas de ação do moinho de bolas convencional e que resultou na mudança 
da forma de dentrítica para achatada (flat) de uma grande parte das partículas do pó. Um outro efeito da ação do moinho pode ser observado da relação entre o gráfico de granulometria da figura 5.4 e a micrografia da figura 5.17 (a) que dá indícios do aumento no tamanho de um pequeno grupo de partículas, do pó de cobre eletrolítico. Essa ocorrência pode ser explicada, por junção de partículas menores, por ação da energia cinética do moinho de bolas em metais de maior ductilidade.

Figura 5.17 Micrografia MEV mostra o tamanho de partículas para o pó de cobre eletrolítico processado em moagem de $36 \mathrm{~h}$.

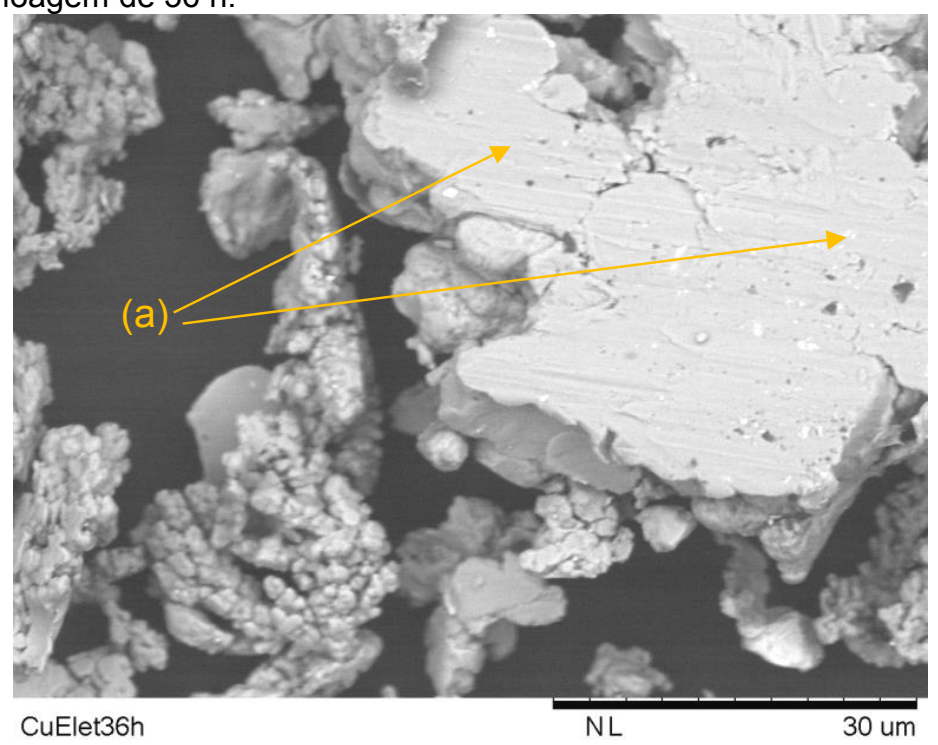

Fonte: criada pelo autor

Na figura 5.18 é apresentada a micrografia do pó de cobre PAC como recebido, em que é possível notar uma distribuição homogênea para o tamanho das partículas e na figura 5.19 pode ser observada a formação de aglomerados de partículas resultantes do processo de atomização. O tamanho médio das partículas no pó de cobre PAC como recebido é de $22 \mu \mathrm{m}$.

Figura 5.18 Micrografia MEV para o pó de cobre PAC como recebido. 


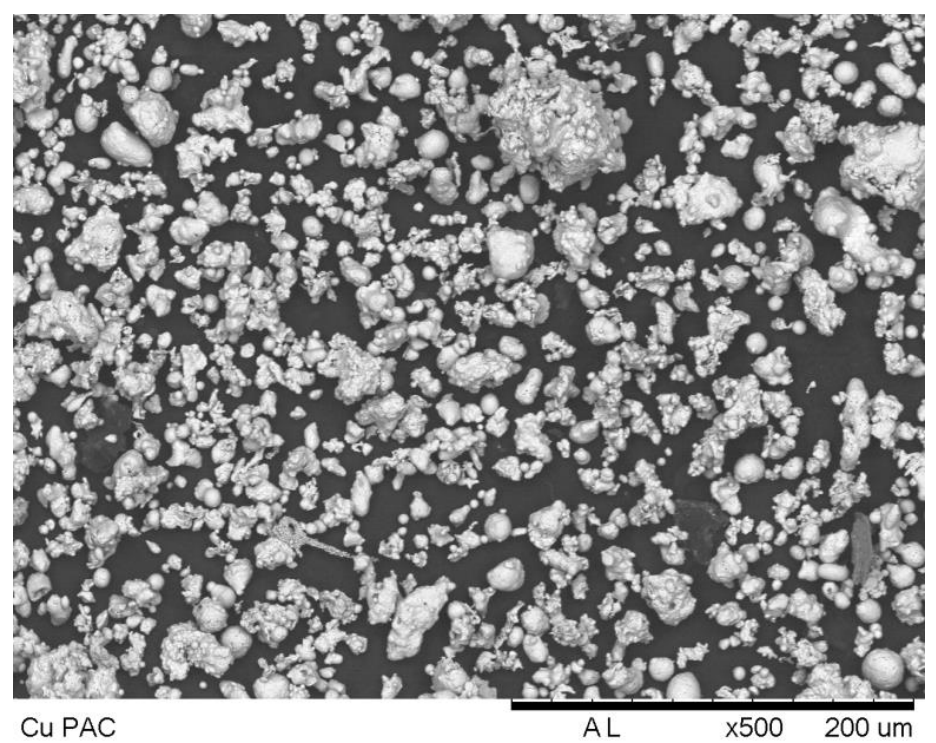

Fonte: criado pelo autor

Figura 5.19 Micrografia MEV mostra a formação de aglomerados de partículas do pó de cobre PAC como recebido.

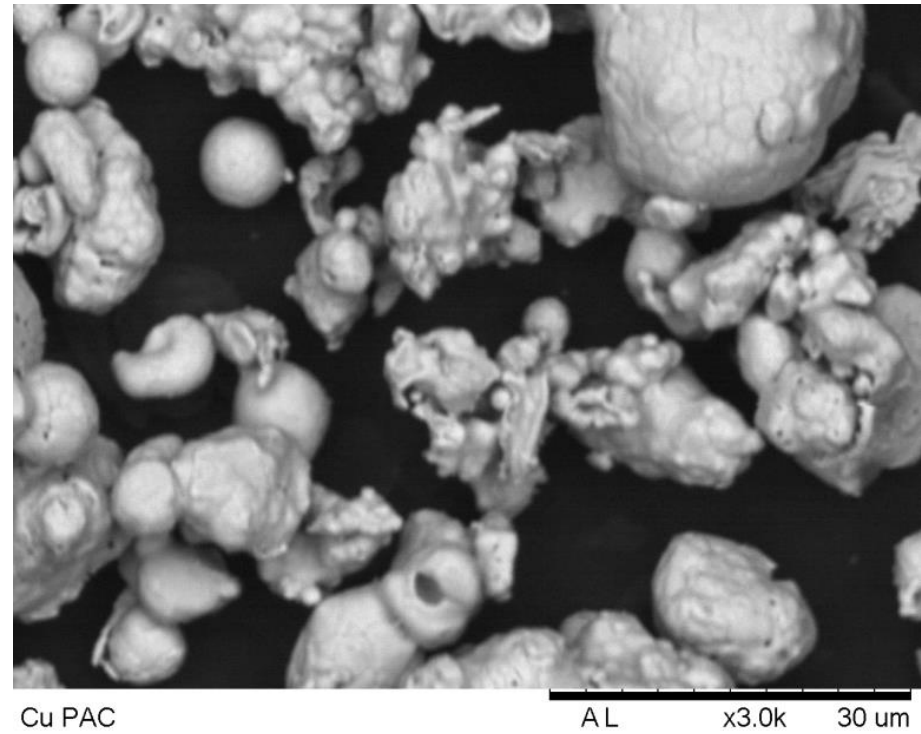

Fonte: criado pelo autor

A figura 5.20 mostra a micrografia do cobre PAC após 36 horas de ação no moinho de bolas convencional e ilustra a formação de aglomerados ,por junção de partículas e de aglomerados menores, resultando em aglomerados de maior diâmetro. A alteração na distribuição do tamanho de partículas no pó do cobre PAC, após moagem pode ser observada por comparação com o gráfico de grannulometria da figura 5.6. 
Figura 5.20 Micrografia MEV mostra partículas formando aglomerados para o pó de cobre PAC processado em moagem de $36 \mathrm{~h}$.

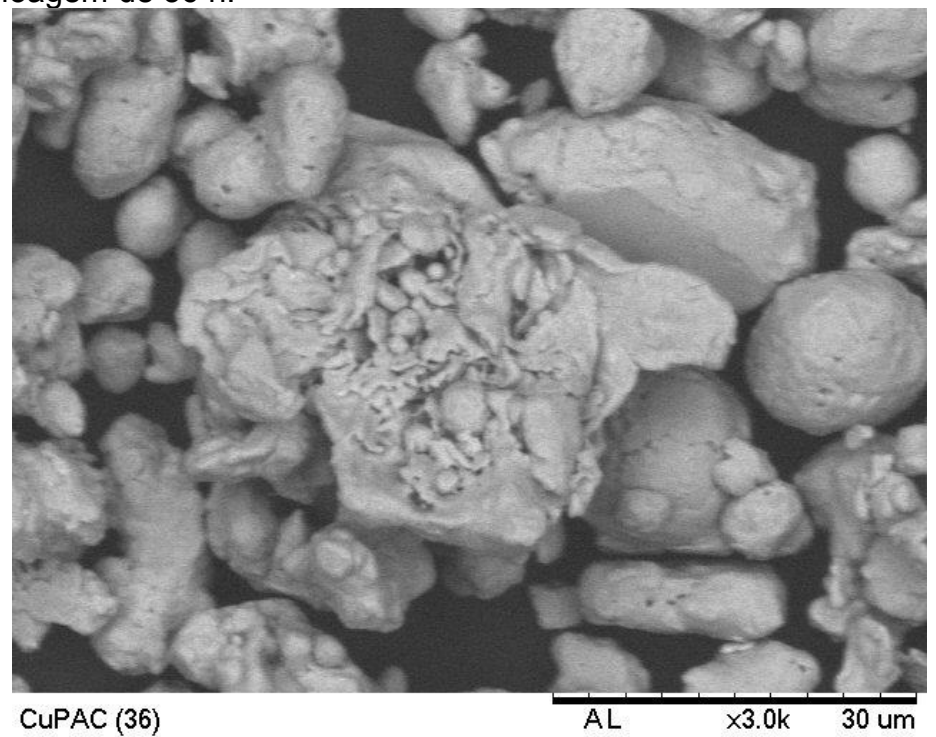

Fonte: criada pelo autor

Na figura 5.21 é apresentada a micrografia do pó de cobre PAM, onde é possível notar uma distribuição homogênia de tamanho das partículas e na figura 5.22 pode ser observada a formação de aglomerados de partículas resultantes do processo de atomização. O tamanho médio das partículas no pó de cobre PAM como recebido é de $23 \mu \mathrm{m}$. A figura 5.23 mostra a micrografia do cobre PAM após ação de 36 hs de moagem e a formação de aglomerados de partículas menores com tendência a formação dentritica.

Figura 5.21 Micrografia MEV mostra a distribuição do tamanho de partículas para o pó de cobre PAM como recebido.

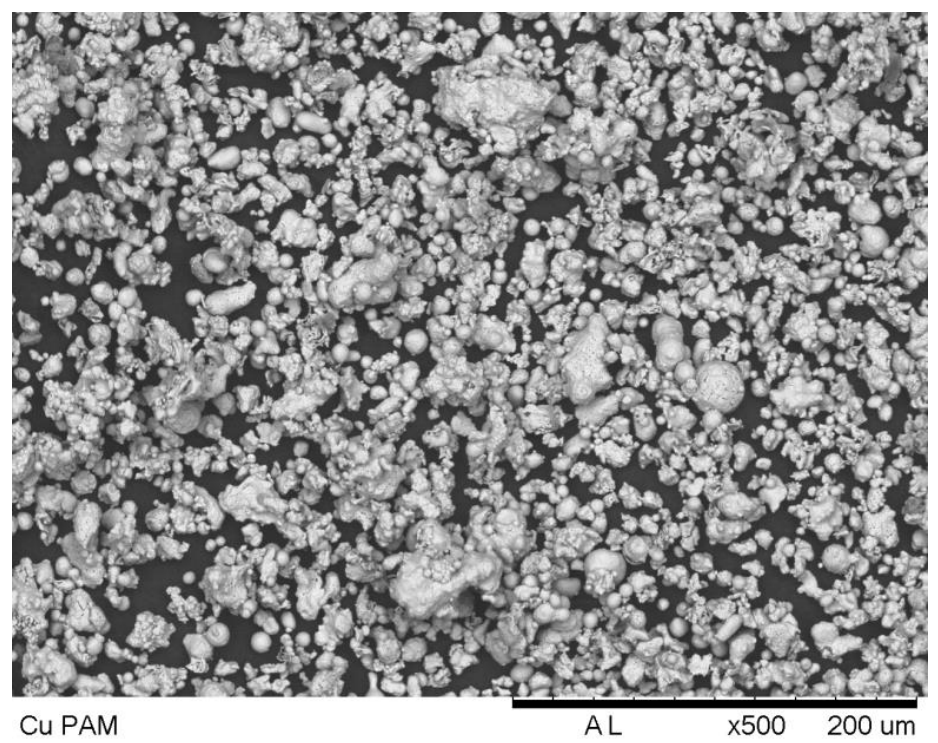


Fonte: criada pelo autor

Figura 5.22 Micrografia MEV mostra a formação de aglomerados de partículas do pó de cobre PAM.

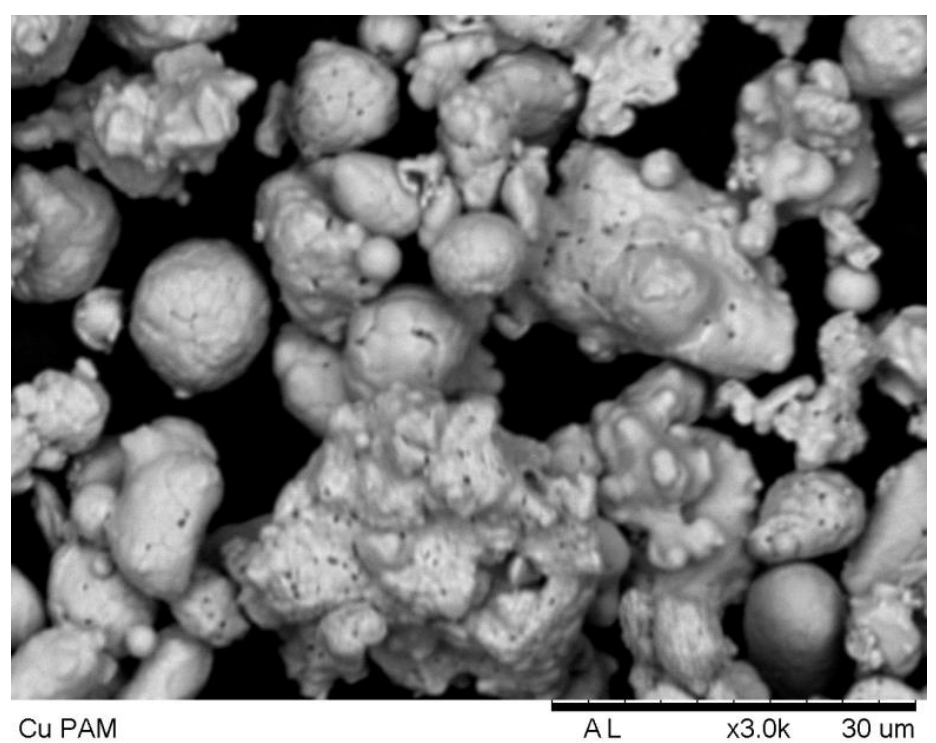

Fonte: criada pelo autor

Figura 5.23 Micrografia MEV mostra o tamanho de partículas para o pó de cobre PAM processado em moagem de $36 \mathrm{~h}$.

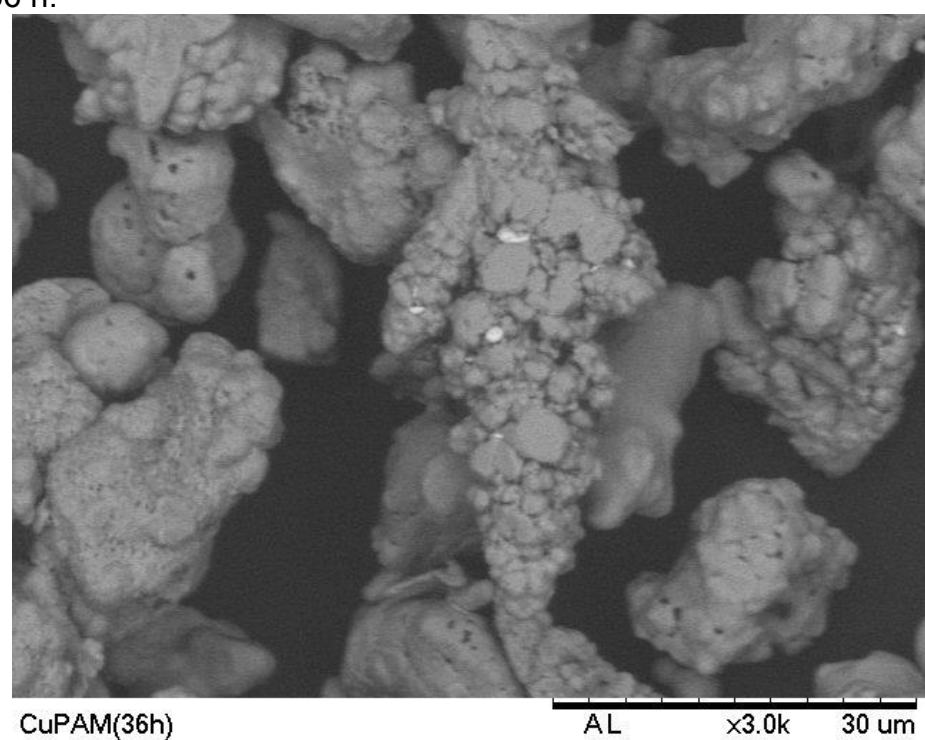

Fonte: criada pelo autor

Na figura 5.24 é apresentada a micrografia do pó de níquel como recebido onde é possível notar partículas esféricas. Na figura 5.25 pode ser observada partículas de forma esféricas e a formação de maiores aglomerados com tendência à formação de partículas de forma irregular, resultantes do processo de atomização. Da comparação ante a micrografia da figura 5.26 com o gráfico de 
granulometria da figura 5.10, em que mostra distribuição bimodal no tamanho das partículas pode ser observado que essa tendência ocorre da junção de partículas resultando em partículas com forma achatada e maior tamanho. O tamanho médio das partículas no pó de níquel é de $18 \mu \mathrm{m}$, porém a média converge para a medida do quartil $D_{50}$.

Figura 5.24 Micrografia MEV mostra a uniformidade na distribuição do tamanho de partículas para o pó de níquel como recebido.

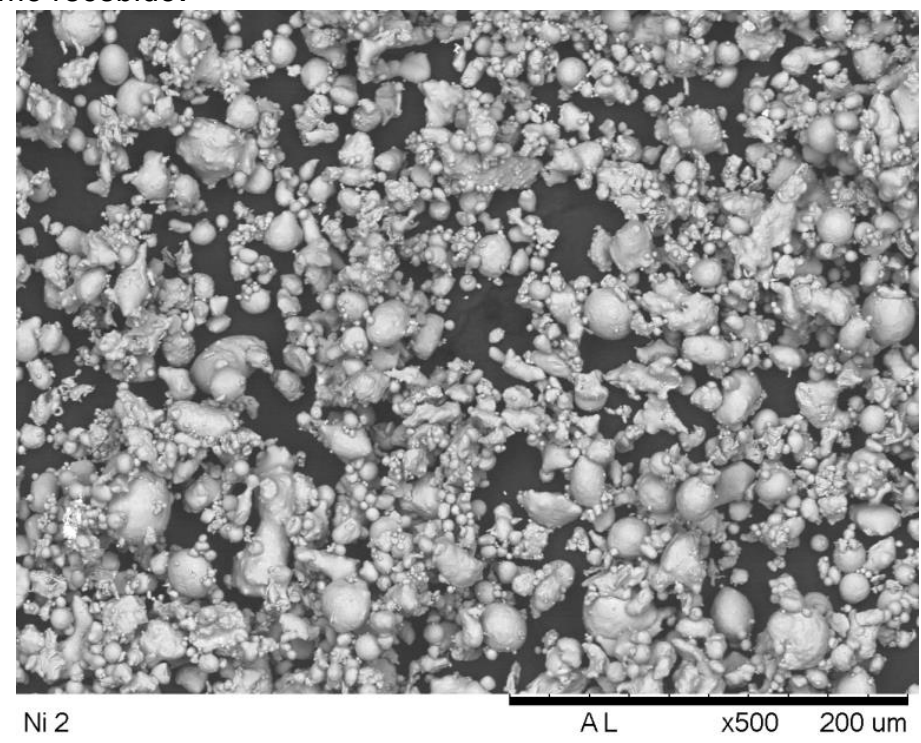

Fonte: criada pelo autor

Figura 5.25 Micrografia MEV mostra a uniformidade na distribuição do tamanho de partículas para o pó de níquel.

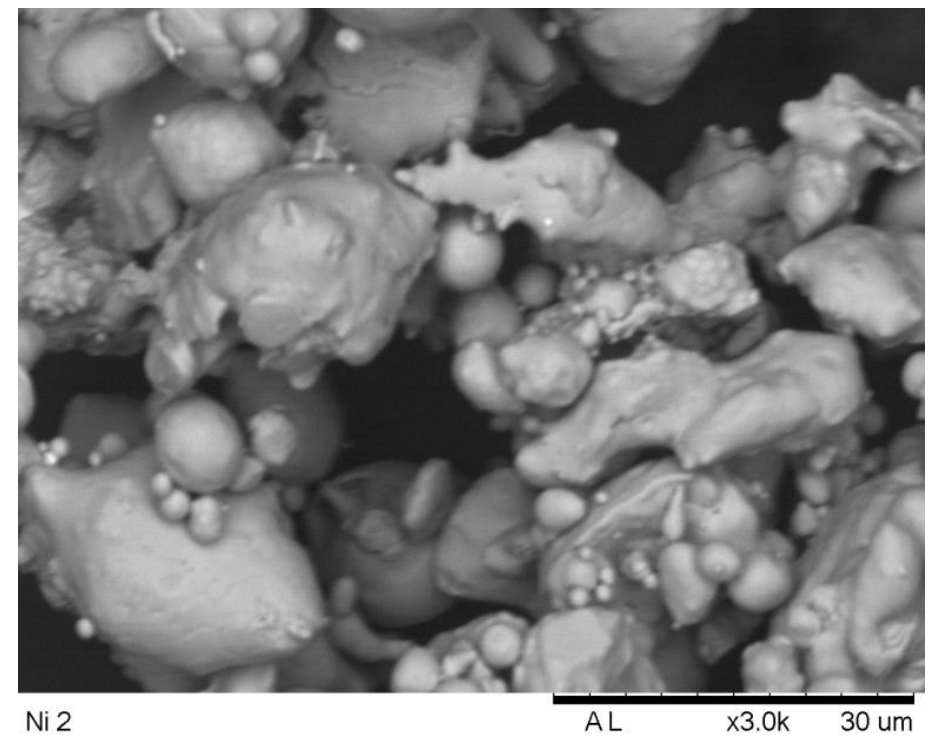

Fonte: criada pelo autor 
Figura 5.26 Micrografia MEV mostra o tamanho de partículas para o pó de níquel processado em moagem de $36 \mathrm{~h}$.

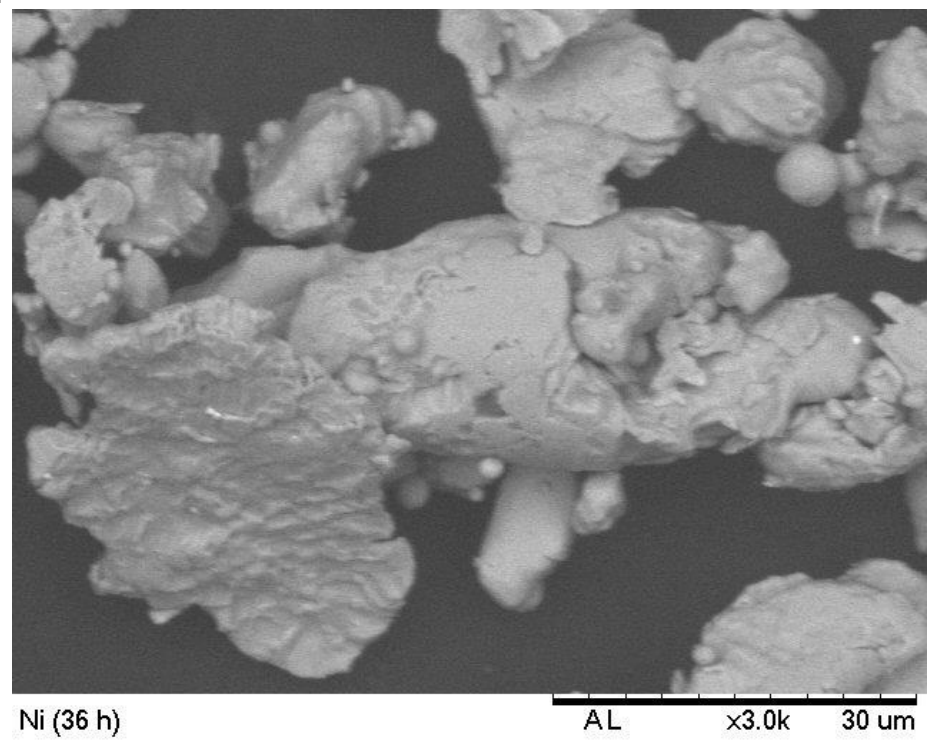

Fonte: criado pelo autor

Os pós elementares como recebido apresentaram pouca similaridade na distribuição de tamanho de partículas. Essa diferença pode ser atribuída aos diferentes processos utilizados para produção do metal pó, como já mencionado em literatura [61, 63, 65]. A redução de tamanho nas partículas dos pós de tungstênio por ação do moinho de bolas pode ser atribuída a fratura frágil [62]. $O$ pó de tungstênio processado por tempo de moagem de $12 \mathrm{~h}$ e $24 \mathrm{~h}$ apresentou pouca alteração de tamanho. O tempo de moagem de 36 horas demonstrou maior eficiência na obtenção de maior homogeinidade na distribuição do tamanho de partículas para o pó de tungstênio.

Nos pós de metais dúcteis (cobre, níquel) pode ser observado os efeitos de junção de partículas menores, formando aglomerado e separação de grandes aglomerados em aglomerados menores. Pode ser observado também a mudança de forma das partículas em todos os pós por ação de moagem. A moagem pode ser considerada uma fase importante na obtenção dos pós de partida na tecnologia de metalurgia do pó. É recomendada a utilização de moinhos convencional e moinhos de alta energia (MAE) para obter redução no tamanho de partículas por ação de fratura ou também para produzir misturas mais homogênias entre pós [62,65,71]. 


\subsection{Compactação}

A ação do moinho de esferas sobre o metal pó de tungstênio foi feita em razão do princípio de que o menor tamanho das partículas do pó de tungstênio possibilita aumento na densidade final do sinterizado. No processamento das misturas pelo moinho convencional de esferas foi possível constatar a redução de tamanho das partículas do pó de tungstênio, porém a redução mais expressiva ocorreu nas primeiras $24 \mathrm{~h}$ da etapa de moagem. A moagem do pó de tungstênio promoveu uma ruptura superficial por fratura e resultando em partículas menores (diâmetro $<1,0 \mu \mathrm{m}$ ). Como resultado secundário da mecânica de fratura ocorreu uma mudança da forma das partículas que passaram de poligonal para irregular.

O cobre eletrolítico como recebido foi utilizado nas primeiras composições de W-Cu obtidas. A densificação atingiu, em média $6,0 \mathrm{~g} \cdot \mathrm{cm}^{-3}$. Este resultado oferece baixo rendimento na atenuação da radiação. Reduzir o tamanho das partículas do pó por moagem foi a solução experimental adotada. Na obtenção do metal pó do cobre por técnica eletrolítica (FFC), por haver maior existência de contaminantes e a tendência de aglomerado das pequenas partículas que tomam a forma dendrítica em resposta à corrente iônica formada. Questiona-se sua aplicabilidade em ligas e compósitos em razão das impurezas e forma do particulado. A produção de cobre via FFC vem sendo bastante discutida em razão do impacto ambiental e o custo de produção desta técnica. [77,78]. Os particulados obtidos por atomização a spray de água e jatos de gás geralmente formam partículas esféricas com tamanhos menores que 5,0 $\mu \mathrm{m}$, mas solidificam em formação de aglomerados irregulares por ancoragem durante o resfriamento.

Segundo German e Sands [65, 67], o aumento da pressão durante o processo de compactação não implica diretamente em proporcional aumento da densidade a verde. $O$ efeito da densificação está, também, relacionado as propriedades do material, como os limites elástico e plástico, além do tamanho e forma das partículas do pó que compõe a mistura. O tamanho e forma dos particulados nos pós da mistura limitam a movimentação e o fator de empacotamento na obtenção do compactado verde.

\subsubsection{Prensagem uniaxial}

A pressão uniaxial convencional é obtida por aplicação de força sobre uma área superficial única e em um único sentido de ação. A pressão axial pode ser de 
dupla ação quando aplicada sobre as duas superfícies da matriz, no mesmo eixo e em sentidos opostos voltados para o centro da cavidade [68]. Como já visto na literatura, o resultado final do compactado depende das características dos pós usados nas misturas e da pressão de compactação. O tamanho e a forma das partículas, sua dureza, a natureza mais frágil ou ductil dos pós na mistura são fatores que influenciam diretamente a escoabilidade e o rearranjo das partículas e resulta na maior possibilidade de obter as propriedades físicas e mecânicas desejadas nos produtos acabados.

A tabela 5.8 lista as densidade a verde média $\left(\overline{D_{v}}\right)$ que ilustra a evolução de densificação no compactado a verde a partir das misturas do sistema $\mathrm{W}-\mathrm{Cu}-\mathrm{Ni}$ em função da pressão de $90 \mathrm{MPa}, 180 \mathrm{MPa}, 270 \mathrm{MPa}$. As densidades informadas foram obtidas por cálculo do volume geométrico, obtenção do valor da massa, por pesagem em balança de precisão e foram desconsiderados o erro sistemáticos intrumentais.

Tabela 5.8 Densidade média a verde $\left(\overline{D_{v}}\right)$ para as composições de misturas do sistema W-Cu-Ni em função da pressão de compactação de $90 \mathrm{MPa}, 180 \mathrm{MPa}$ e $270 \mathrm{MPa}$.

\begin{tabular}{llccc}
\hline Nomenclatura & $\begin{array}{c}\text { Densidade } \\
\text { / composição }\end{array}$ & $\begin{array}{c}\text { teórica } \\
\left(\mathrm{g} . \mathrm{cm}^{-3}\right)\end{array}$ & \multicolumn{3}{c}{$\begin{array}{c}\left(\overline{D_{v}}\right) \text { densidade verde }\left(\mathrm{g} . \mathrm{cm}^{-3}\right) \text { versus } \\
\text { compactação }(\mathrm{MPa})\end{array}$} \\
\cline { 3 - 5 } W5Cu & 18,78 & 90 & 180 & 270 \\
\hline W10Cu & 18,26 & 11,55 & 13,62 & 15,14 \\
\hline W15Cu & 17,74 & 10,65 & 11,37 & 13,61 \\
\hline W20Cu & 17,23 & 10,69 & 11,90 & 14,22 \\
\hline W25Cu & 16,71 & 9,27 & 9,81 & 10,63
\end{tabular}

Fonte: criada pelo autor

A figura 5.27 apresenta o gráfico de densidades média $\left(\overline{D_{v}}\right)$, obtida por prensagem uniaxial convencional, para as pressões de compactação de $90 \mathrm{MPa}$, $180 \mathrm{MPa}$ e $270 \mathrm{MPa}$. O segmento de reta que liga os pontos referente às pressões de compactação de $90 \mathrm{MPa}, 180 \mathrm{MPa}$ e $270 \mathrm{MPa}$ tem a finalidade de ilustrar a tendência de comportamento nas diferentes pressões. 
Figura 5.27 Gráfico representando o comportamento de densificação das misturas W-Cu-Ni obtidas por compactação a $90 \mathrm{MPa}, 180 \mathrm{MPa}$ e $270 \mathrm{MPa}$.

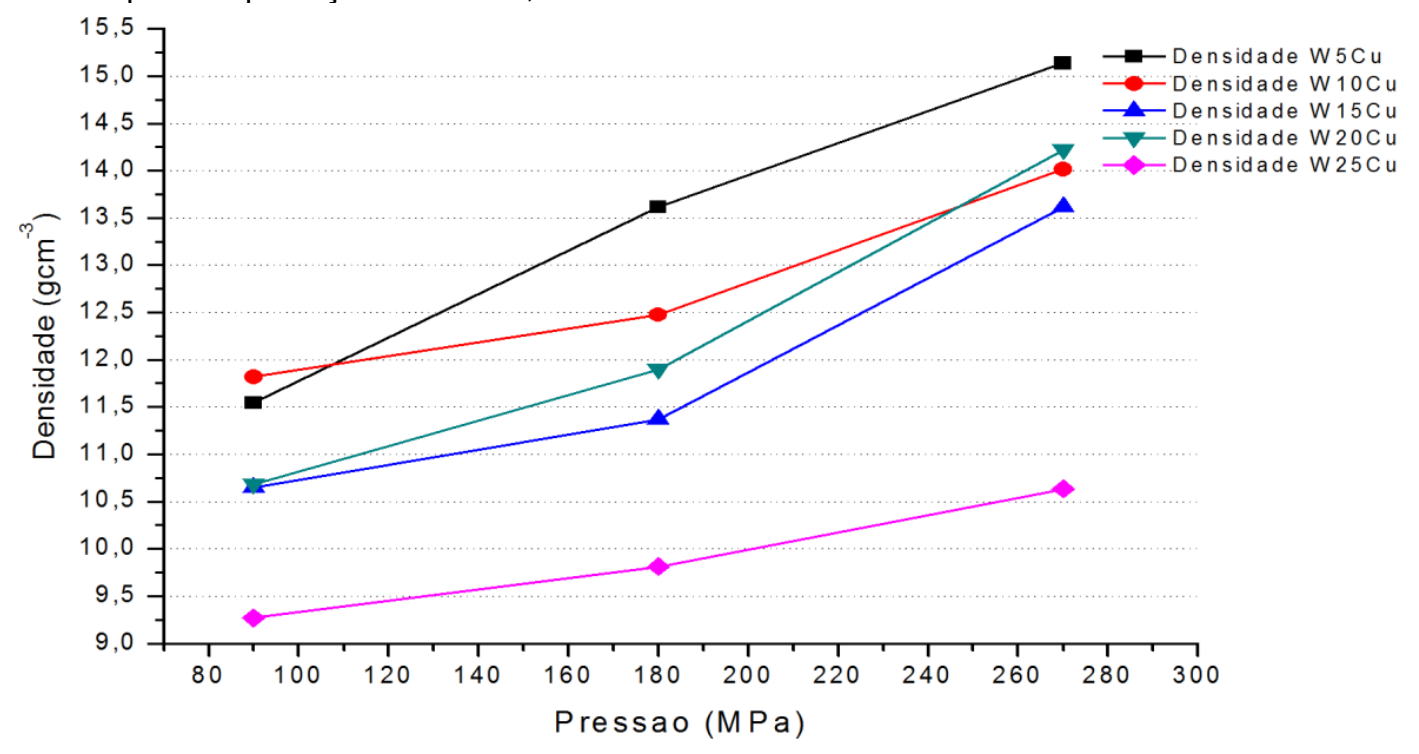

Fonte: criada pelo autor

A tabela 5.9 lista as densidades, a verde média $\left(\overline{D_{v}}\right)$ e a figura 5.28 apresenta o gráfico que ilustra a evolução de densificação no compactado a verde, obtidas a partir das misturas do sistema W-Cu-Ni.em função da pressão de $90 \mathrm{MPa}, 180 \mathrm{MPa}, 270 \mathrm{MPa}$.

Tabela 5.9 Densidade média a verde $\left(\overline{D_{v}}\right)$ em função da pressão de compactação do conjunto de misturas do sistema W-Cu-Ni.

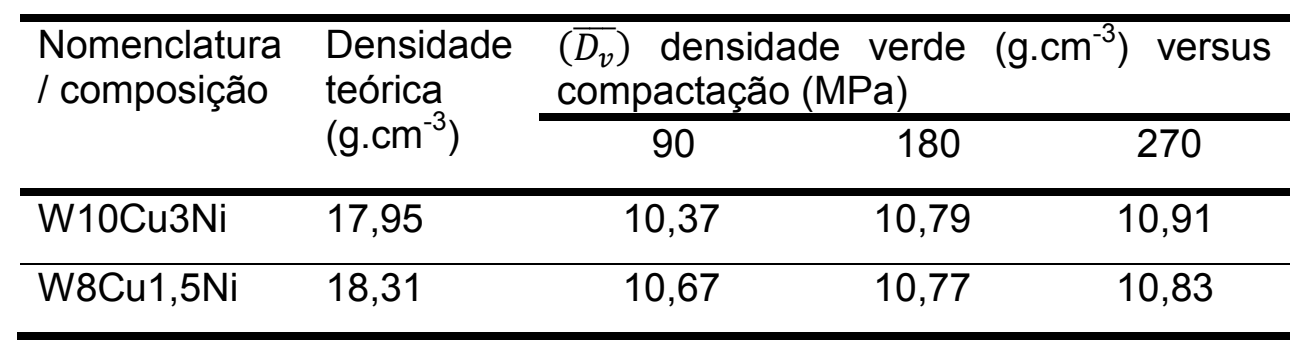

Fonte: criada pelo autor 
Figura 5.28 Gráfico representando o comportamento de densificação das misturas W-Cu obtidas durante a compactação a $90 \mathrm{MPa}, 180 \mathrm{MPa}$ e $270 \mathrm{MPA}$ em prensa uniaxial convencional.

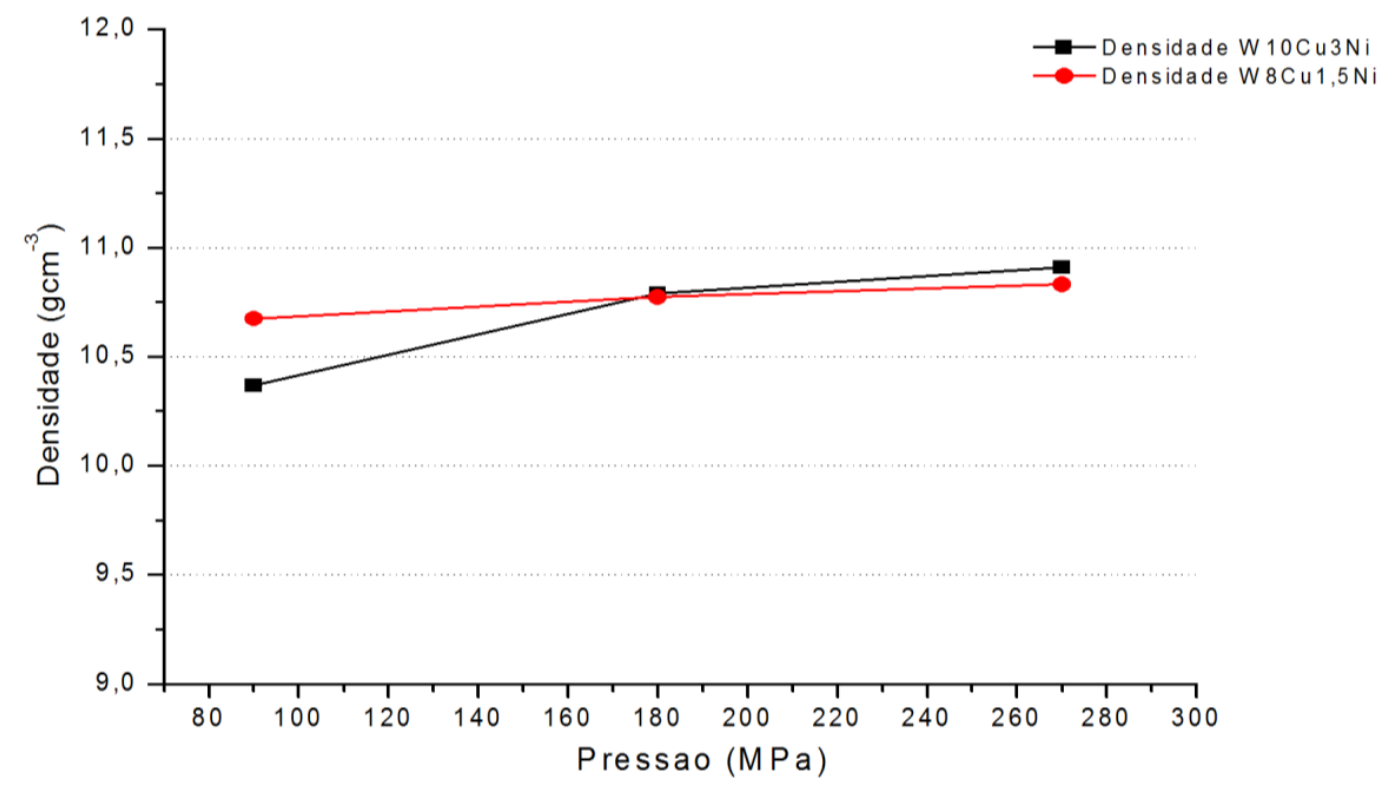

Fonte: criada pelo autor

A tabela 5.10 lista as densidades verde média $\left(\overline{D_{v}}\right)$ e a figura 5.29 ilustra o comportamento de densificação obtido para as misturas do sistema W-Cu-Ni compactadas nas pressões de $180 \mathrm{MPa}, 270 \mathrm{MPa}, 480 \mathrm{MPa}$ e $650 \mathrm{MPa}$.

Tabela 5.10 Densidade média a verde $\left(\overline{D_{v}}\right)$ em função da pressão de compactação do conjunto de misturas do sistema W-Cu-Ni compactadas sob pressões de $180 \mathrm{MPa}, 270 \mathrm{MPa}, 480 \mathrm{MPa}$ e 650 $\mathrm{MPa}$.

\begin{tabular}{|c|c|c|c|c|c|}
\hline \multirow[t]{2}{*}{$\begin{array}{l}\text { Nomenclatura } \\
\text { / composição }\end{array}$} & \multirow{2}{*}{$\begin{array}{l}\text { Densidade } \\
\text { teórica } \\
\left(\mathrm{g} \mathrm{cm}^{-3}\right)\end{array}$} & \multicolumn{4}{|c|}{$\begin{array}{l}\left(\overline{D_{v}}\right) \text { densidade verde }\left(\mathrm{g} \mathrm{cm}^{-3}\right) \text { versus compactação } \\
(\mathrm{MPa})\end{array}$} \\
\hline & & 180 & 270 & 480 & 650 \\
\hline W20Cu3Ni & 16,91 & 5,54 & 7,15 & 8,14 & 8,68 \\
\hline W10Cu2Ni & 18,06 & 11,54 & 12,06 & 13,08 & 13,08 \\
\hline W10Cu1,5Ni & 18,11 & 11,44 & 12,78 & 13,00 & 12,94 \\
\hline W8Cu1,5Ni & 18,31 & 10,37 & 10,68 & 12,54 & 12,96 \\
\hline W6Cu1Ni & 18,57 & 10,37 & 11,68 & 13,58 & 13,38 \\
\hline
\end{tabular}

Fonte: criada pelo autor 
Figura 5.29 Comportamento da densificação das misturas obtidas durante a compactação a 180 $\mathrm{MPa}, 270 \mathrm{MPA}, 400 \mathrm{MPa}, 600 \mathrm{MPa}$ e $850 \mathrm{MPa}$ em prensa uniaxial a frio convencional.

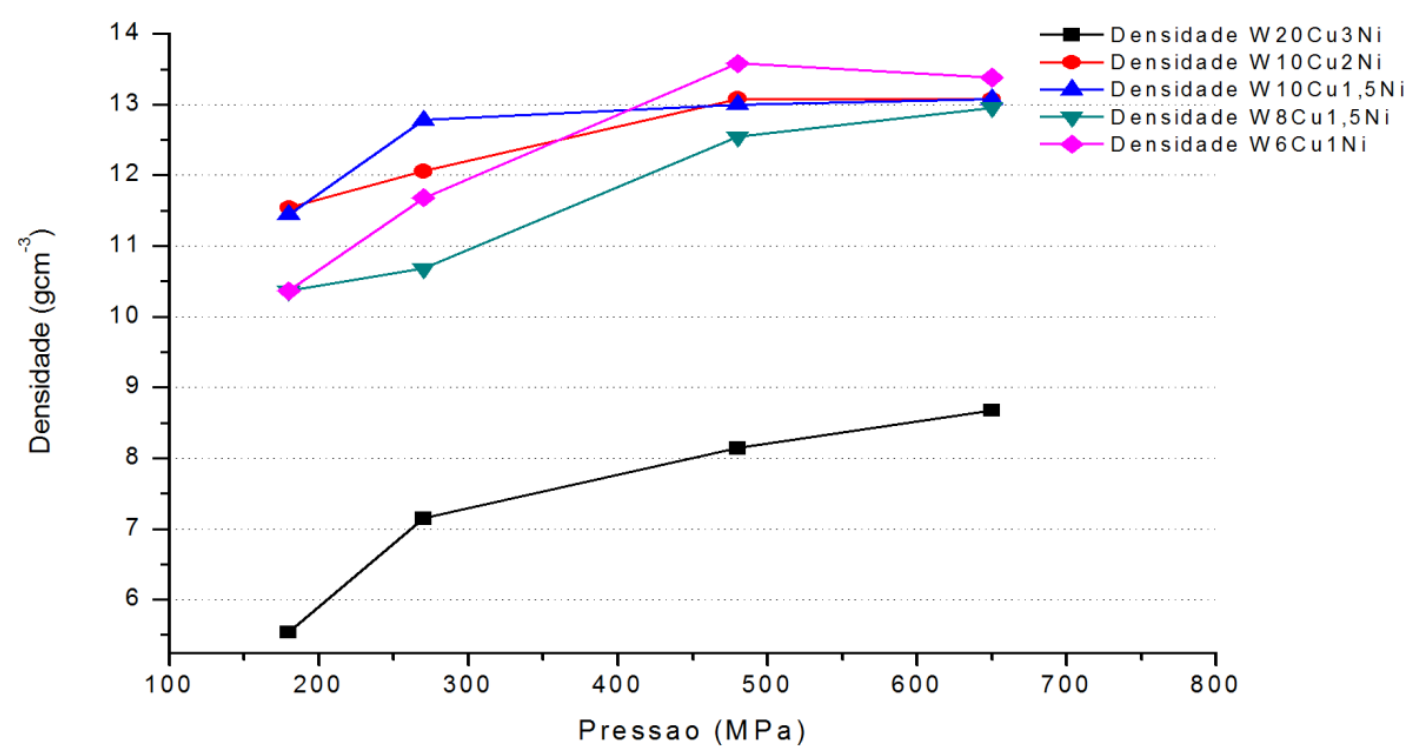

Fonte: criada pelo autor

\subsubsection{Prensagem uniaxial dupla ação}

Segundo German $[67,68]$ e Schwarzkopf [72], o balanço de forças durante a compactação é a diferença entre a pressão aplicada e a pressão transmitida resultante. A prensagem uniaxial de dupla ação é definida pela aplicação da pressão nos dois punções, esta técnica tem como vantagem melhor eficiência na distribuição da pressão, ao longo da espessura do compactado (gradiente de distribuição da pressão) reduzindo o efeito da força de atrito entre partículas e entre as partículas da mistura e a parede da matriz durante a ação da pressão de compactação.

A tabela 5.11 ilustra a relação entre pressão e densidade obtida com o uso da prensa uniaxial de dupla ação sobre os punções em pressão de compactação de $480 \mathrm{MPa}, 520 \mathrm{MPa}$ e $650 \mathrm{MPa}$.

Tabela 5.11 Densidade média a verde $\left(\overline{D_{v}}\right)$ para as pressões de $520 \mathrm{MPa}$ e $650 \mathrm{MPa}$ em prensagem uniaxial dupla ação.

\begin{tabular}{|c|c|c|c|c|}
\hline \multirow[t]{2}{*}{$\begin{array}{l}\text { Nomenclatura } \\
\text { / composição }\end{array}$} & \multirow{2}{*}{$\begin{array}{l}\text { Densidade } \\
\text { teórica } \\
\left(\mathrm{g} \mathrm{cm}^{-3}\right)\end{array}$} & \multicolumn{3}{|c|}{$\begin{array}{l}\left(\overline{D_{v}}\right) \text { densidade a verde }\left(\mathrm{g} \mathrm{cm}^{-3}\right) \text { versus } \\
\text { compactação }(\mathrm{MPa})\end{array}$} \\
\hline & & 480 & 520 & 680 \\
\hline $\mathrm{W} 20 \mathrm{Cu}$ & 17,23 & 12,06 & 13,08 & 13,38 \\
\hline W15Cu & 17,74 & 12,96 & 13,58 & 13,76 \\
\hline
\end{tabular}

Fonte: criada pelo autor 
Na figura 5.30 é apresentado o gráfico do comportamento de densificação das misturas do sistema W-Cu, em função da pressão de compactação de 480 MPa, $520 \mathrm{MPa}$ e $650 \mathrm{MPa}$ para prensagem uniaxial dupla ação a frio.

Figura 5.30 Gráfico representando o comportamento de densificação das misturas obtidas em compactação a $480 \mathrm{MPa}, 520 \mathrm{MPa}$ e $680 \mathrm{MPa}$ em prensa uniaxial dupla ação.

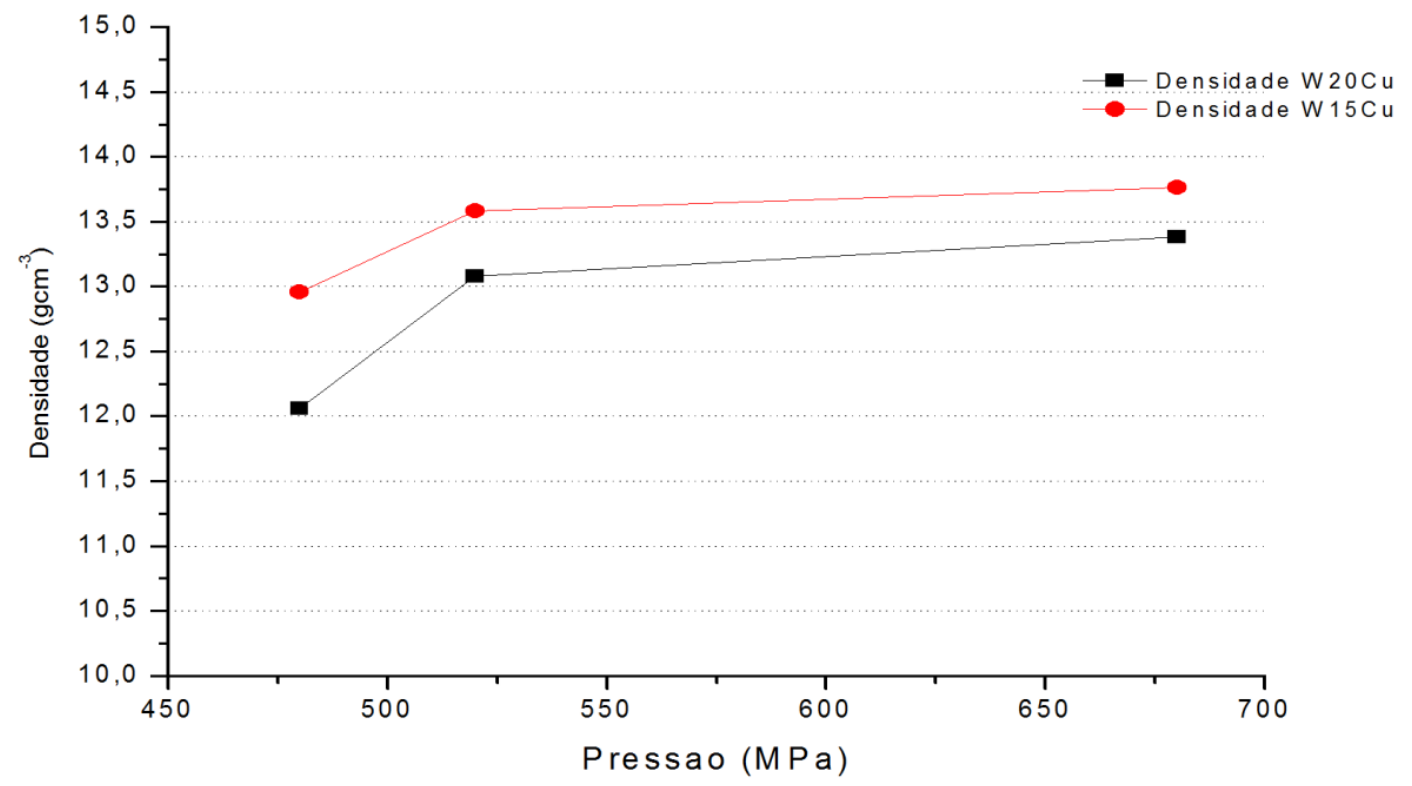

Fonte: criada pelo autor

\subsubsection{Isostática}

A tabela 5.12 ilustra a relação entre a pressão e a densidade alcançada no uso da prensa isostática utilizando pressões de $190 \mathrm{MPa}$ e $210 \mathrm{MPa}$ para os diversos sistemas $\mathrm{W} 1,5 \mathrm{Ni}, \mathrm{W} 1 \mathrm{Ni}$ e $\mathrm{W} 0,5 \mathrm{Ni}$.

Tabela 5.12 Densidade média a verde $\left(\overline{D_{v}}\right)$ para o conjunto de misturas do sistema W-Ni em função da pressão de compactação isostática de $190 \mathrm{MPa}$, e $210 \mathrm{MPa}$.

\begin{tabular}{llcc}
\hline Nomenclatura & $\begin{array}{l}\text { Densidade } \\
\text { l composição }\end{array}$ & $\begin{array}{l}\left(\overline{D_{v}}\right) \text { densidade a verde } \\
\text { teórica } \\
\left(\mathrm{g} . \mathrm{cm}^{-3}\right)\end{array}$ & $\left.190 \mathrm{~cm}^{-3}\right)$ versus \\
\cline { 3 - 4 } & 19,14 & 8,82 & 210 \\
\hline W1,5Ni & 19,20 & 9,04 & 9,33 \\
\hline W1Ni & 19,25 & 9,72 & 9,70 \\
\hline W0,5Ni & & & 10,03 \\
\hline
\end{tabular}

Fonte: criada pelo autor

A figura 5.31 mostra o gráfico representando o comportamento de densificação para as misturas W1,5Ni, W1Ni e W0,5Ni por ação de compactação 
isostática em pressões de $190 \mathrm{MPa}$ e $210 \mathrm{MPa}$.

Figura 5.31 Gráfico representando o comportamento de densificação das misturas W-Ni em compactação isostática em pressões de $190 \mathrm{MPa}$ e $210 \mathrm{MPa}$.

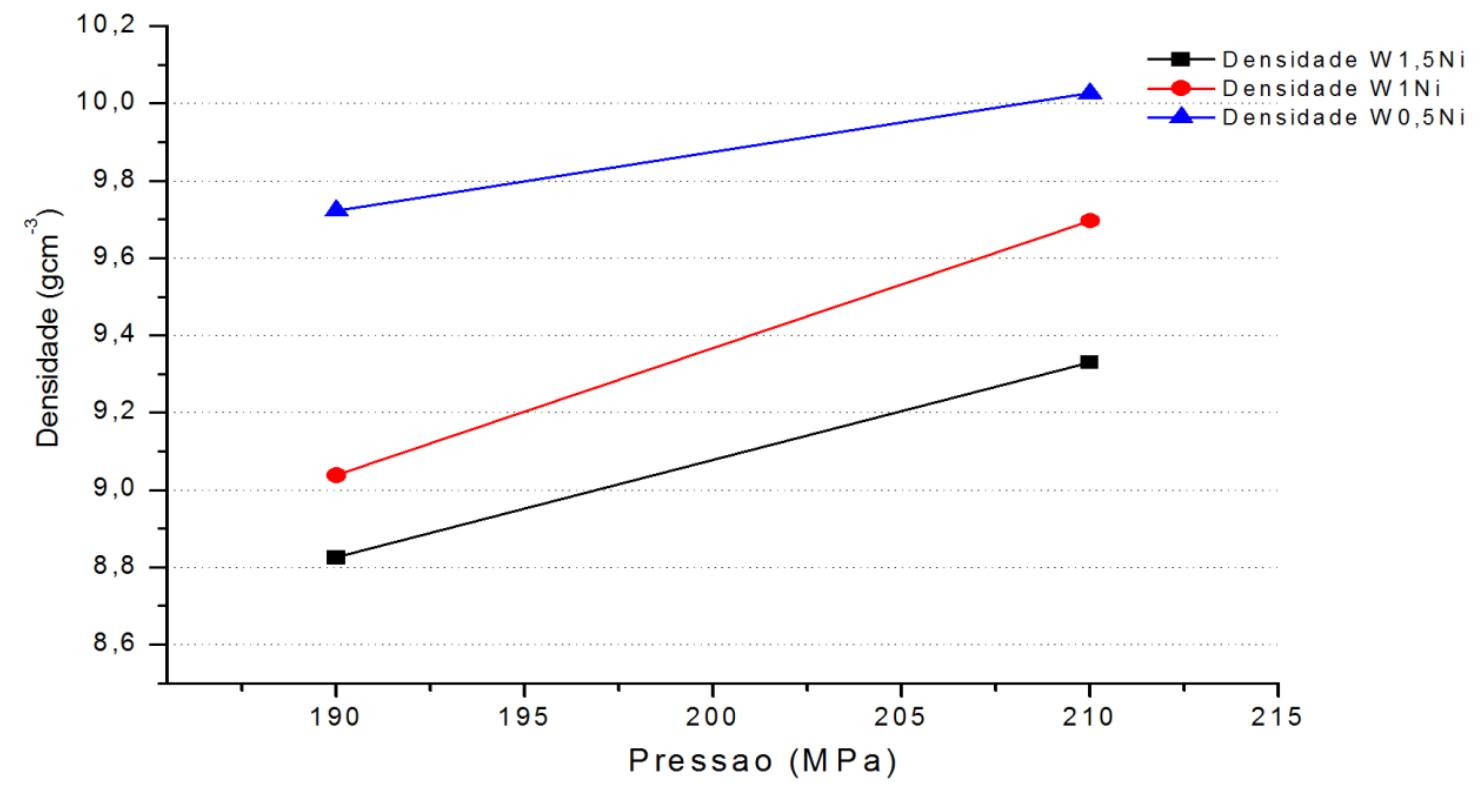

Fonte: criada pelo autor

A tabela 5.13 ilustra a relação entre a pressão e a densidade alcançada no uso da prensa isostática, utilizando pressões de $190 \mathrm{MPa}$ e $210 \mathrm{MPa}$ para os diversos sistemas $\mathrm{W} 10 \mathrm{Cu} 0,5 \mathrm{Ni}, \mathrm{W} 9 \mathrm{Cu} 0,5 \mathrm{Ni}, \mathrm{W} 8 \mathrm{Cu0}, 5 \mathrm{Ni}$ e W6Cu0,5Ni.

Tabela 5.13 Densidade média a verde $\left(\overline{D_{v}}\right)$ para o conjunto de misturas do sistema W-Cu-Ni em função da pressão de compactação compactadas por pressão isostática de $190 \mathrm{MPa}$, e $210 \mathrm{MPa}$.

\begin{tabular}{llcc}
\hline $\begin{array}{l}\text { Nomenclatura } \\
\text { / composição }\end{array}$ & $\begin{array}{l}\text { Densidade } \\
\text { teórica } \\
\left(\mathrm{g} \cdot \mathrm{cm}^{-3}\right)\end{array}$ & $\begin{array}{l}\left(\overline{D_{v}}\right) \text { densidade a verde } \\
\text { compactação }(\mathrm{MPa})\end{array}$ & 190 \\
\cline { 3 - 4 } & & $\left.8, \mathrm{~cm}^{-3}\right)$ versus \\
\hline W10Cu0,5Ni & 18,21 & 8,50 & 210 \\
\hline W9Cu0,5Ni & 18,31 & 9,79 & 8,70 \\
\hline W8Cu0,5Ni & 18,44 & 10,01 & 9,05 \\
\hline W6Cu0,5Ni & 18,52 & & 10,10 \\
\hline
\end{tabular}

Fonte: criada pelo autor

A figura 5.32 mostra o gráfico representando o comportamento de densificação para as misturas $W 10 \mathrm{Cu} 0,5 \mathrm{Ni}, W 9 \mathrm{Cu} 0,5 \mathrm{Ni}, \mathrm{W} 8 \mathrm{Cu} 0,5 \mathrm{Ni}$ e W6Cu0,5Ni por ação de compactação isostática, em pressões de $190 \mathrm{MPa}$ e 210 MPa. 
Figura 5.32 Gráfico representando o comportamento de densificação das misturas W-Cu-Ni em compactação isostática em pressões de $190 \mathrm{MPa}$ e $210 \mathrm{MPa}$.

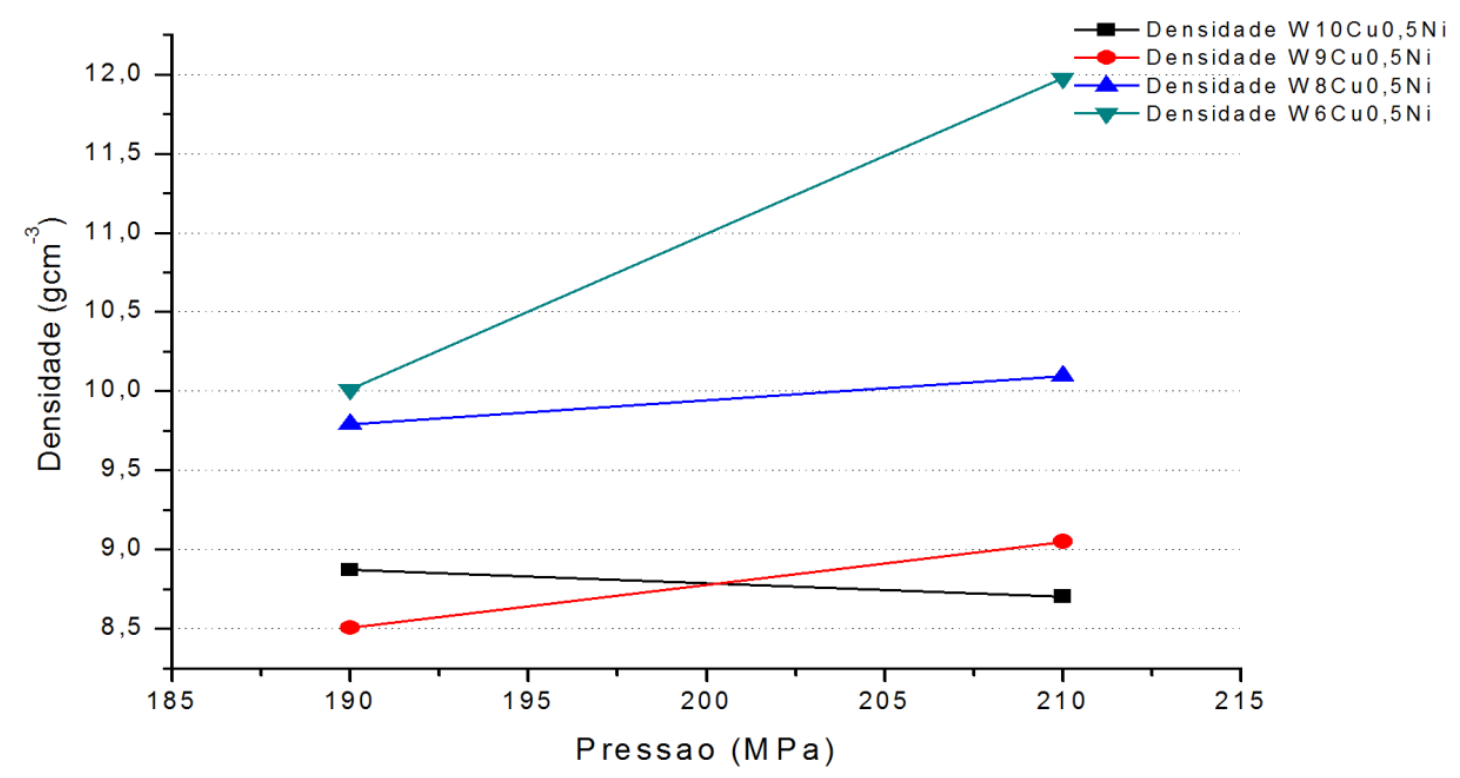

Fonte: criada pelo autor

A tabela 5.14 ilustra a relação entre a pressão e a densidade alcançada no uso da prensa isostática utilizando pressões de $190 \mathrm{MPa}$ e $210 \mathrm{MPa}$ para os diversos sistemas W10Cu1,5Ni e W10Cu1Ni.

Tabela 5.14 Densidade média a verde $\left(\overline{D_{v}}\right)$ para o conjunto de misturas do sistema W-Cu-Ni em função da pressão de compactação compactadas por pressão isostática de $190 \mathrm{MPa}$ e $210 \mathrm{MPa}$.

\begin{tabular}{|c|c|c|c|}
\hline \multirow[t]{2}{*}{$\begin{array}{l}\text { Nomenclatura } \\
\text { / composição }\end{array}$} & \multirow{2}{*}{$\begin{array}{l}\text { Densidade } \\
\text { teórica } \\
\left(\mathrm{g} \mathrm{cm}^{-3}\right)\end{array}$} & \multicolumn{2}{|c|}{$\begin{array}{l}\left(\overline{D_{v}}\right) \text { densidade a verde }\left(\mathrm{g} \mathrm{cm}^{-3}\right) \text { versus } \\
\text { compactação }(\mathrm{MPa})\end{array}$} \\
\hline & & 190 & 210 \\
\hline W10Cu1,5Ni & 18,11 & 8,70 & 9,34 \\
\hline W10Cu1Ni & 18,16 & 9,01 & 9,48 \\
\hline
\end{tabular}

Fonte: criada pelo autor

A figura 5.33 mostra o gráfico representando o comportamento de densificação para as misturas W10Cu1,5Ni e W10Cu1Ni por ação de compactação isostática em pressões de $190 \mathrm{MPa}$ e $210 \mathrm{MPa}$. 
Figura 5.33 Gráfico representando o comportamento de densificação das misturas W-Cu-Ni em compactação isostática em pressões de $190 \mathrm{MPa}$ e $210 \mathrm{MPa}$.

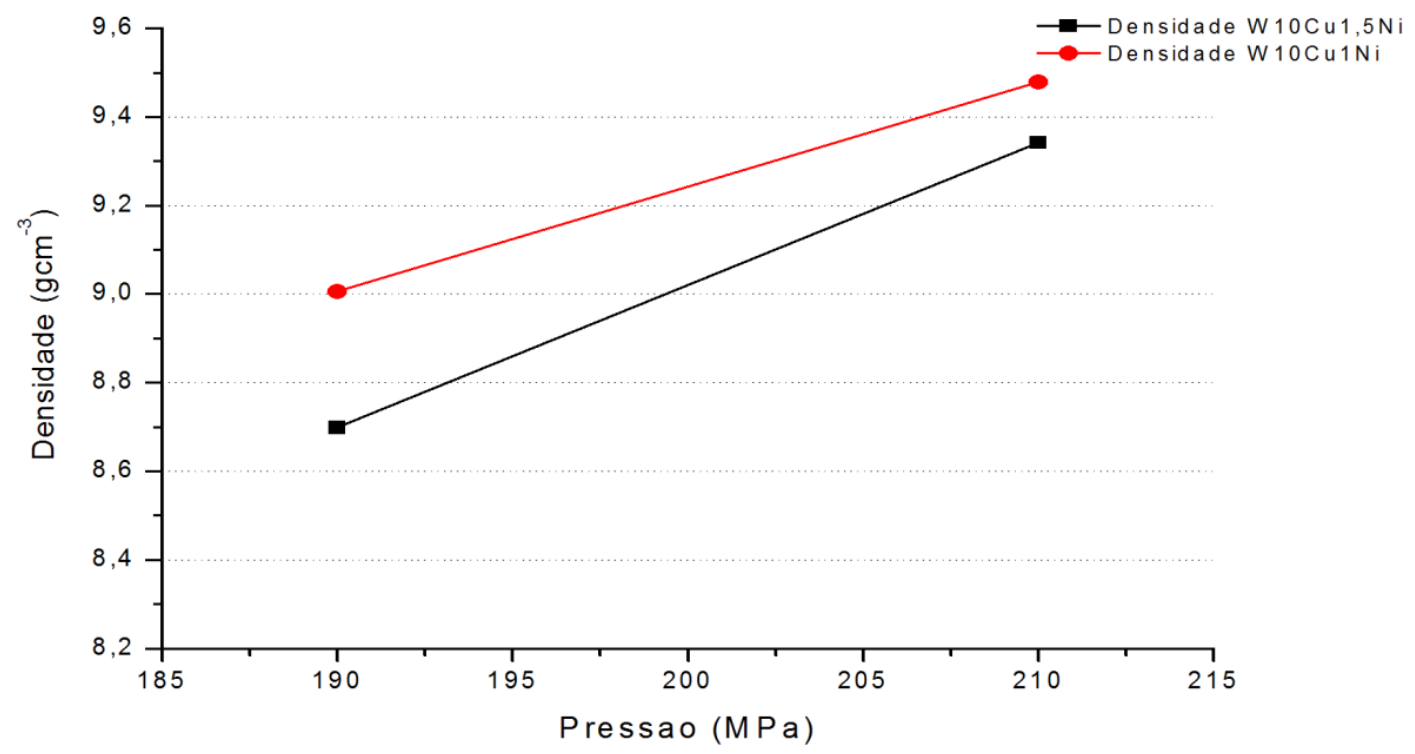

Fonte: criada pelo autor

A tabela 5.15 ilustra a relação entre a pressão e a densidade alcançada no uso da prensa isostática utilizando pressões de $190 \mathrm{MPa}$ e $210 \mathrm{MPa}$ para os diversos sistemas W9Cu1,5Ni e W9Cu1Ni.

Tabela 5.15 Densidade média a verde $\left(\overline{D_{v}}\right)$ para o conjunto de misturas do sistema W-Cu-Ni em função da pressão de compactação compactadas por pressão isostática de $190 \mathrm{MPa}$, e $210 \mathrm{MPa}$.

\begin{tabular}{|c|c|c|c|}
\hline \multirow[t]{2}{*}{$\begin{array}{l}\text { Nomenclatura } \\
\text { / composição }\end{array}$} & \multirow{2}{*}{$\begin{array}{l}\text { Densidade } \\
\text { teórica } \\
\left(\mathrm{g}_{\mathrm{cm}} \mathrm{cm}^{-3}\right)\end{array}$} & \multicolumn{2}{|c|}{$\begin{array}{l}\left(\overline{D_{v}}\right) \text { densidade a verde }\left(\mathrm{g} \cdot \mathrm{cm}^{-3}\right) \text { versus } \\
\text { compactação }(\mathrm{MPa})\end{array}$} \\
\hline & & 190 & 210 \\
\hline W9Cu1,5Ni & 18,21 & $\overline{9,41}$ & $\overline{10,34}$ \\
\hline W9Cu1Ni & 18,26 & 8,75 & 9,03 \\
\hline
\end{tabular}

Fonte: criada pelo autor

A figura 5.34 mostra o gráfico representando o comportamento de densificação para as misturas W9Cu1,5Ni e W9Cu1Ni, por ação de compactação isostática em pressões de $190 \mathrm{MPa}$ e $210 \mathrm{MPa}$.

Figura 5.34 Gráfico representando o comportamento de densificação das misturas W-Cu-Ni obtidas em compactação isostática a 190 MPa, 210 MPa. 


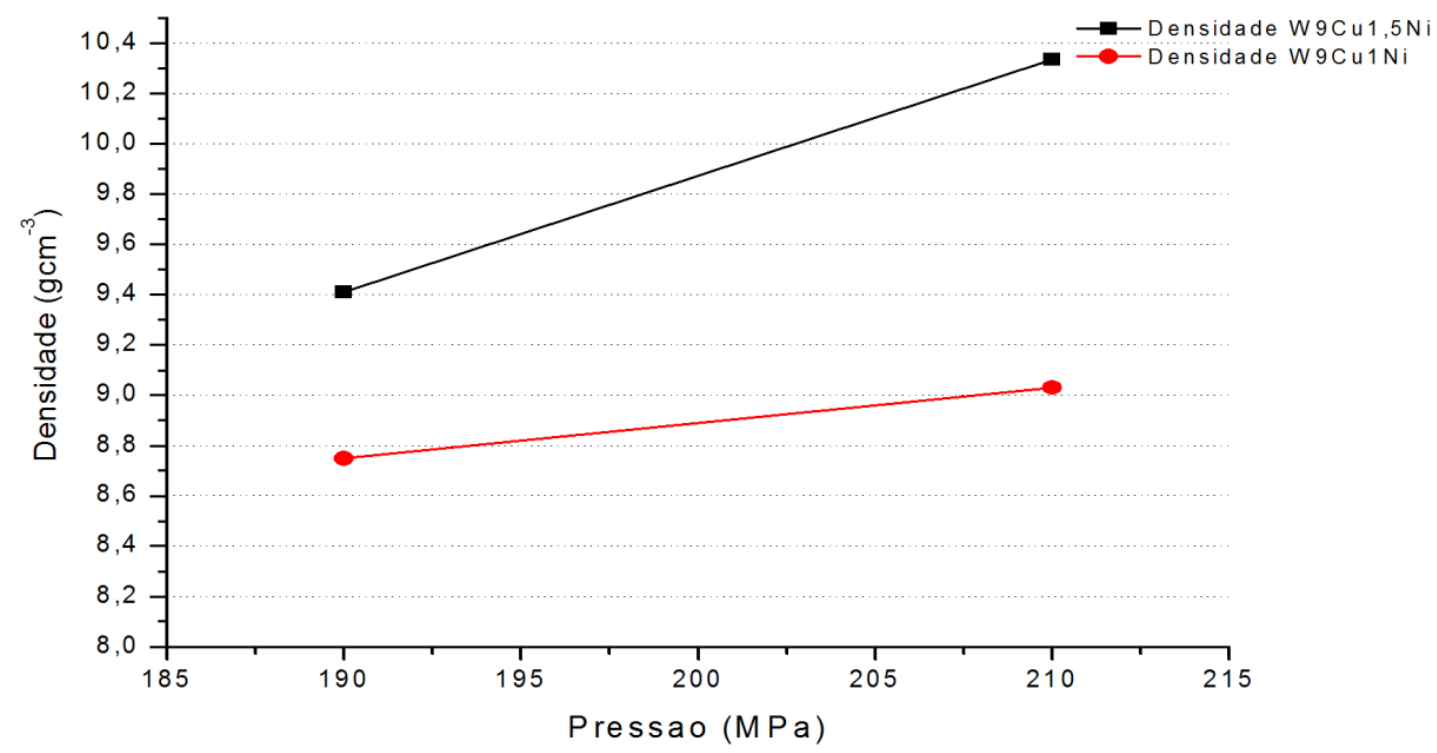

Fonte: criada pelo autor

A tabela 5.16 ilustra a relação entre a pressão e a densidade alcançada no uso da prensa isostática utilizando pressões de $190 \mathrm{MPa}$ e $210 \mathrm{MPa}$ para os diversos sistemas W8Cu1,5Ni e W8Cu1Ni.

Tabela 5.16 Densidade média a verde $\left(\overline{D_{v}}\right)$ para o conjunto de misturas do sistema W-Cu-Ni em função da pressão de compactação compactadas por pressão isostática de $190 \mathrm{MPa}$ e $210 \mathrm{MPa}$.

\begin{tabular}{|c|c|c|c|}
\hline \multirow[t]{2}{*}{$\begin{array}{l}\text { Nomenclatura } \\
\text { / composição }\end{array}$} & \multirow{2}{*}{$\begin{array}{l}\text { Densidade } \\
\text { teórica } \\
\left(\mathrm{g} \mathrm{cm}^{-3}\right)\end{array}$} & \multicolumn{2}{|c|}{$\begin{array}{l}\left(\overline{D_{v}}\right) \text { densidade a verde }\left(\mathrm{g} \mathrm{cm}^{-3}\right) \text { versus } \\
\text { compactação }(\mathrm{MPa})\end{array}$} \\
\hline & & 190 & 210 \\
\hline W8Cu1,5Ni & 18,31 & 8,99 & 9,02 \\
\hline W8Cu1Ni & 18,37 & 9,80 & 9,89 \\
\hline
\end{tabular}

Fonte: criada pelo autor

A figura 5.35 mostra o gráfico representando o comportamento de densificação para as misturas W8Cu1,5Ni e W8Cu1Ni por ação de compactação isostática em pressões de $190 \mathrm{MPa}$ e $210 \mathrm{MPa}$. 
Figura 5.35 Gráfico representando o comportamento de densificação das misturas W-Cu-Ni em compactação isostática em pressões de $190 \mathrm{MPa}$ e $210 \mathrm{MPa}$.

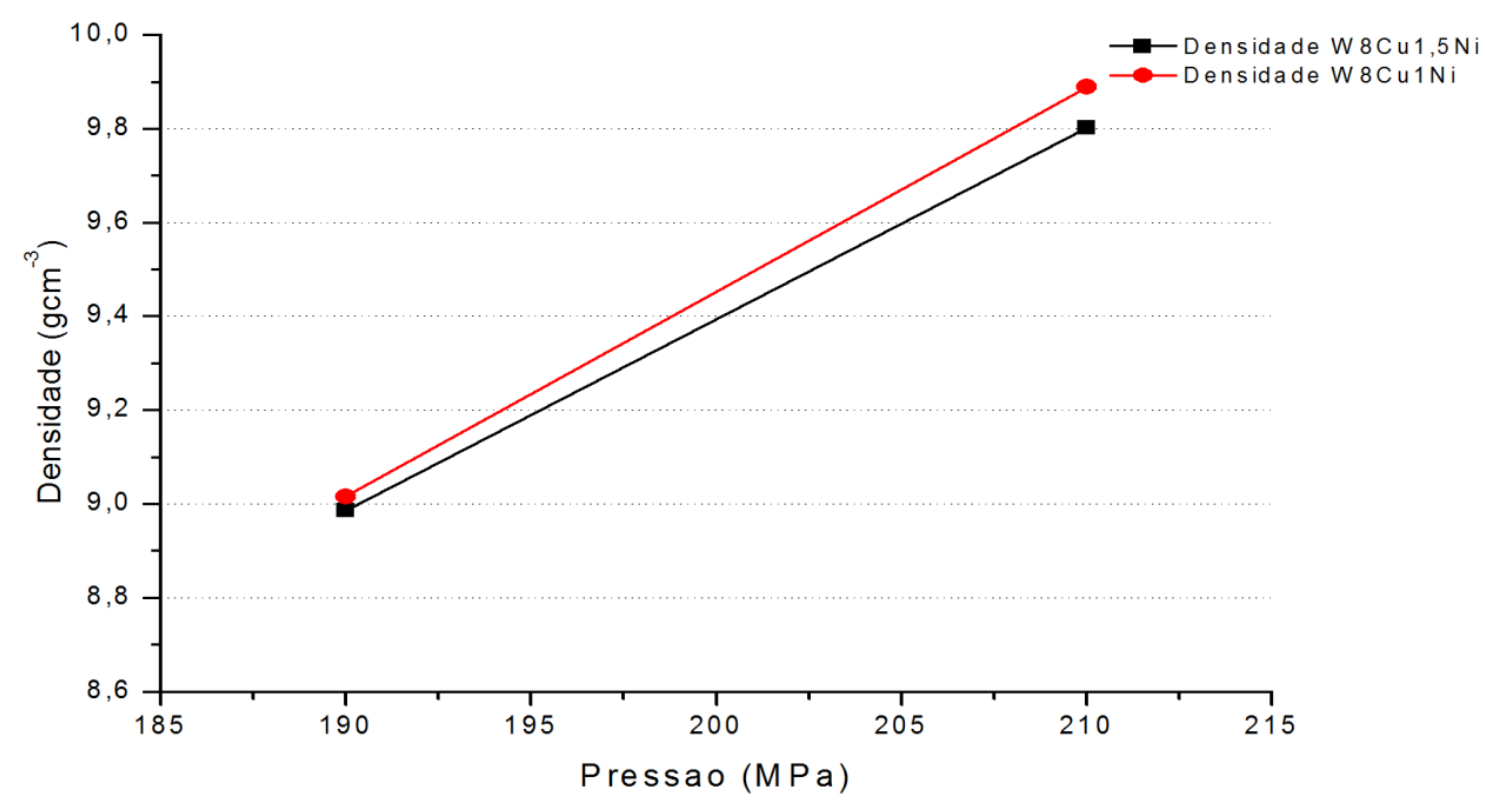

Fonte: criada pelo autor

A tabela 5.16 ilustra a relação entre a pressão e a densidade alcançada no uso da prensa isostática utilizando pressões de $190 \mathrm{MPa}$ e $210 \mathrm{MPa}$ para os diversos sistemas W6Cu1,5Ni e W6Cu1Ni.

Tabela 5.17 Densidade média a verde $\left(\overline{D_{v}}\right)$ para o conjunto de misturas do sistema W-Cu-Ni em função da pressão de compactação compactadas por pressão isostática de $190 \mathrm{MPa}$ e $210 \mathrm{MPa}$.

\begin{tabular}{llcc}
\hline $\begin{array}{l}\text { Nomenclatura } \\
\text { / composição }\end{array}$ & $\begin{array}{l}\text { Densidade } \\
\text { teórica } \\
\left(\mathrm{g} \cdot \mathrm{cm}^{-3}\right)\end{array}$ & $\begin{array}{l}\left(\overline{D_{v}}\right) \text { densidade a verde } \\
\text { compactação }(\mathrm{MPa})\end{array}$ & $\left.19 \mathrm{~cm}^{-3}\right)$ versus \\
\cline { 3 - 4 } & 18,52 & 10,50 & 210 \\
\hline W6Cu1,5Ni & 10,50 & 11,91 \\
\hline W6Cu1Ni & 18,57 & 10,72 & 13,34 \\
\hline
\end{tabular}

Fonte: criada pelo autor

A figura 5.36 mostra o gráfico representando o comportamento de densificação para as misturas W6Cu1,5Ni e W6Cu1Ni por ação de compactação isostática em pressões de 190 MPa e 210 MPa. 
Figura 5.36 Gráfico representando o comportamento de densificação das misturas W-Cu-Ni em compactação isostática em pressões de $190 \mathrm{MPa}$ e $210 \mathrm{MPa}$.

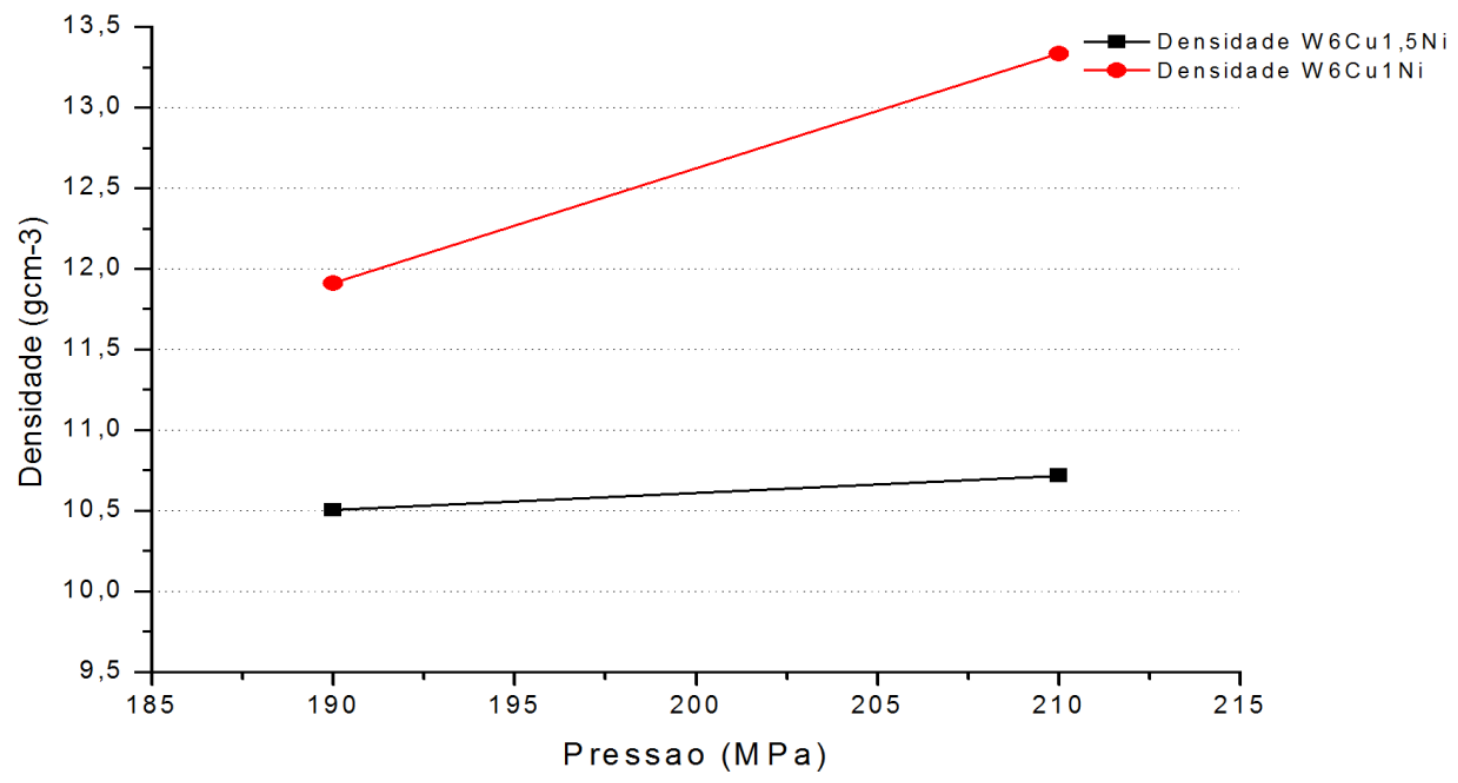

Fonte: criada pelo autor

As composições em massa que apresentaram os melhores resultados em valor médio de densidade foram as misturas W10Cu1,5Ni, W9Cu1,5Ni, W9Cu1Ni e W6Cu1Ni, nos processos de compactação utilizados.

Foi constatado que a redução no tamanho de partículas por ação de moagem promoveu maior empacotamento das partículas durante a compactação. As medidas de tamanho de partículas pelos testes por peneiramento e da análise de granulometria (CILAS) demonstraram que o tamanho das partículas de tungstênio como recebido e após moagem de 36 horas tiveram uma redistribuição na medida de diâmetro médio e na distribuição dos tamanhos para os pós.

As micrografias mostraram mudança na forma das partículas dos pós, após a ação de moagem por 36 horas. Pelas alterações nas propriedades dos pós foi possível obter uma melhor taxa de empacotamento e resultando em maior densificação em função da maior escoabilidade e mobilidade das partículas no processo de compactação.

German e Dowson [69,71] afirmam que no processo de compactação com partículas de tamanho reduzido e regularidade, auxiliam na dinâmica do rearranjo das partículas nos pós quando sob pressão no conjunto mecânico da matriz (característica de cavidade). Estes fatores são importantes para o aumento da resistência mecânica no compactado a verde e na redução de porosidade do produto final. Ao considerar as diferenças entre as técnicas de compactação 
uniaxial convencional e uniaxial de dupla ação, com a técnica de distribuição isostática é constatado as principais vantagens e desvantagens descritas em literatura. A técnica de compactação isostática permite uma distribuição homogênea da pressão sobre o volume do compactado, porém apresenta limites menores de aplicação da pressão. Entre as técnicas de pressão uniaxial, a de dupla ação apresenta como vantagem maior homogeneidade na distribuição da pressão sobre as superfícies da amostra e redução da porosidade quando comparada com as amostras produzidas por compactação uniaxial convencional $[65,67,71]$.

De acordo com Kuhn [74] o processo de obtenção do pó é o fator que determina a forma da partícula. Segundo resultados comparativos de Costa [62] sobre as técnicas de obtenção do tungstênio por redução química resulta em pó de partículas finas com baixa variação de forma.

\subsection{Sinterização}

\subsubsection{Sinterização ao ar}

Pode ser observado que no processo de sinterização utilizando forno resistivo com temperatura de $1.100^{\circ} \mathrm{C}$ ao ar resultou em oxidação parcial e total mistura com composição de teor $\mathrm{W} 20 \mathrm{Cu}, \mathrm{W} 15 \mathrm{Cu}$ e $\mathrm{W} 10 \mathrm{Cu}$. A adição na composição do pó níquel (W-Cu-Ni) em teor de W10Cu3Ni ou W10Cu1Ni reduziu o processo de oxidação durante a sinterização, entretanto estas amostras também sofreram oxidação, em condições ambiente que provocaram redução da resistência mecânica.

Agren [136] postula que o mecanismo de oxidação se dá pela alta taxa de difusão do oxigênio entre os átomos superficiais de tungstênio e que aumenta por efeito da energia livre na região de contato do compactado.

Como resultado a sinterização de amostras das composições $\mathrm{W} 20 \mathrm{Cu}$, W15Cu e W10Cu, em atmosfera Ar, experimentando redução da pressão para 1,0 $\times 10^{-2}$ atm foram obtidas amostra com baixa resistência mecânica, sem aspecto metálico com variações dimensional e irregularidade de volume.

As amostras do sistema $\mathrm{WxCu}(10<\mathrm{x}<25)$ não apresentaram ancoragem e adesão entre as partículas do metal pó tungstênio, devido a reação de oxidação e não mantiveram a estrutura de sólido necessária como ilustra a figura 5.37. 
Figura 5.37 Imagem ilustrativa de amostras da composição W-Cu oxidada.

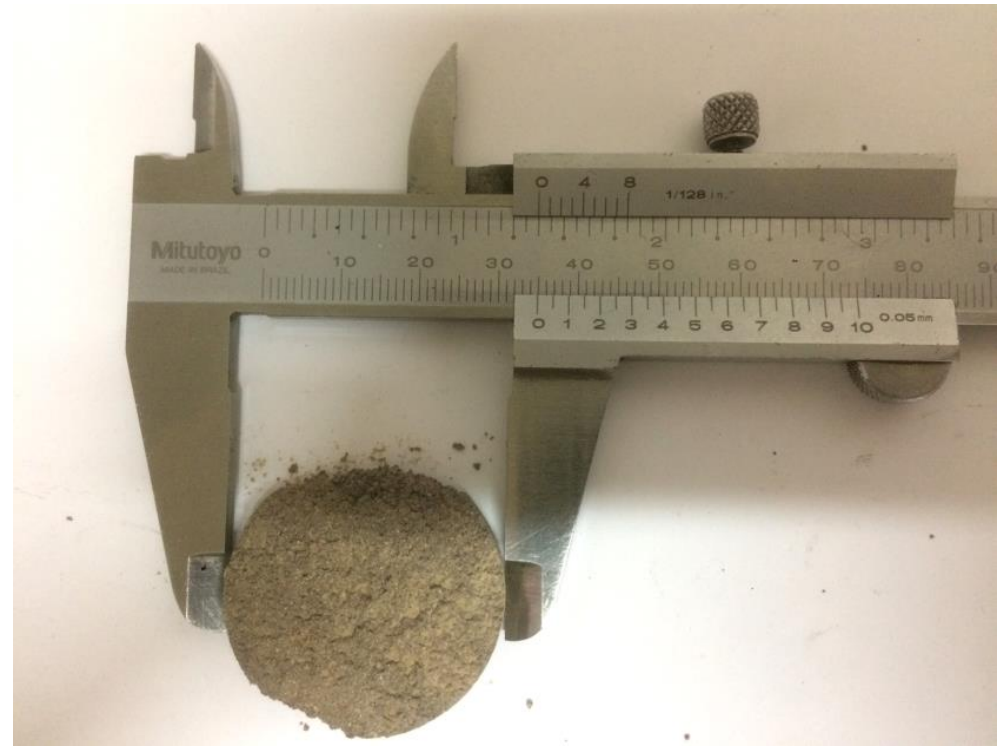

Fonte: fotografada pelo autor

A figura 5.38 ilustra a microscopia óptica onde é apresentado a formação do trióxido de tungstênio na superfície das amostras do sistema W-Cu, destacando a ausência de junção e ancoragem, entre os particulados do pó metálico de tungstênio, com formação de pequenos blocos e aglomerados partículas sem constituição de corpo sólido.

Figura 5.38 Micrografia óptica da amostra de composição W-Cu oxidada.

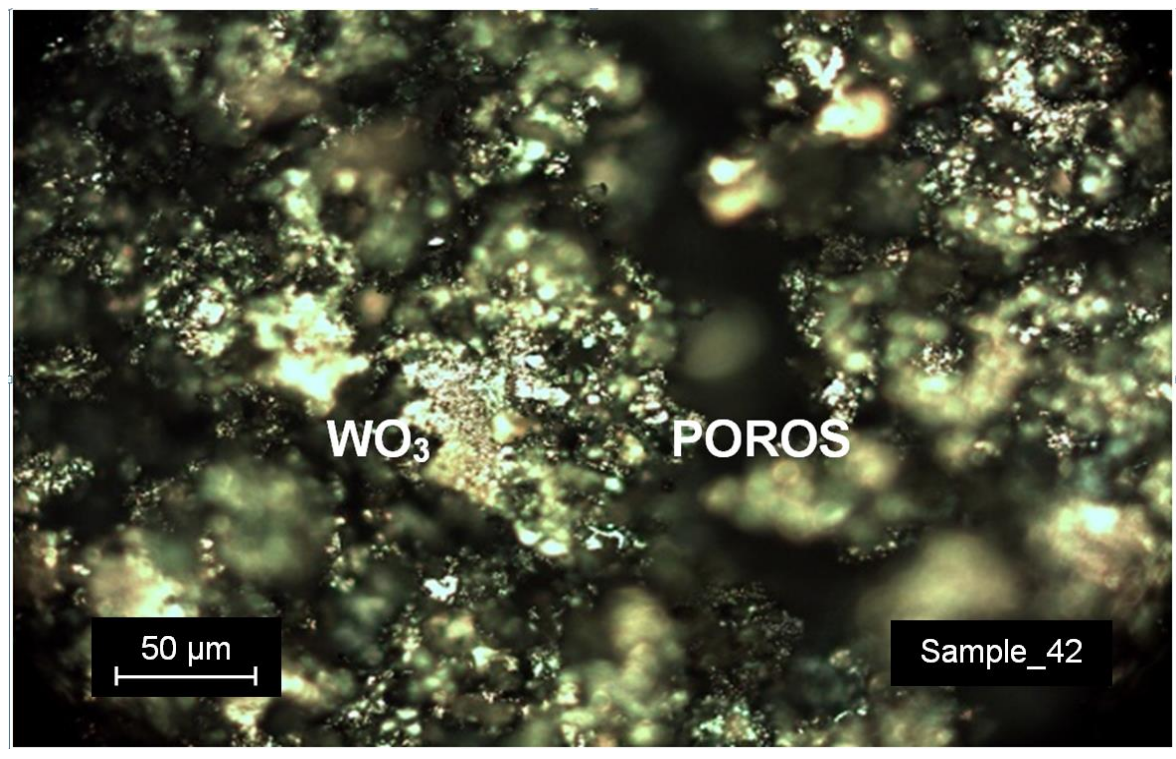

Fonte: criada pelo autor

Segundo Habainy e Nilsson [52,53] a oxidação no tungstênio ocorre devido 
à existência de oxigênio e vapor de água presente e aprisionado nos poros. No tungstênio, a oxidação pode ocorrer em temperatura ambiente e é acelerada entre as temperaturas entre $400{ }^{\circ} \mathrm{C}$ e $900{ }^{\circ} \mathrm{C}$. Logo o produto de oxidação apresenta características de esponja provocando o modo expandido da massa total do pó metal de tungstênio e a coloração amarelo-esverdeada.

$\mathrm{O}$ vapor de água retido em poros e a absorção direta de $\mathrm{O}_{2}$, disponível na atmosfera de sinterização é fator que induz a oxidação do tungstênio e de outros componentes da mistura $[71,73,130]$.

\subsubsection{Fluxo com hidrogênio $\left(\mathrm{H}_{2}\right)$}

A sinterização utilizando o sistema de forno industrial de esteira rotativa com fluxo de gás inerte de ação protetiva $\left(90 \mathrm{~N}_{2} 10 \mathrm{H}_{2}\right)$, permitiu obter amostras do sistema W-Cu com aparência de sólido e resistência mecânica na junção de partículas, mas apresentaram oxidação superficial. A figura 5.39 ilustra a superfície de amostra do sistema W-Cu obtida por essa técnica de sinterização.

Figura 5.39 Micrografia ótica da superfície da amostra do sistema W-Cu sinterizada em forno industrial de esteira.

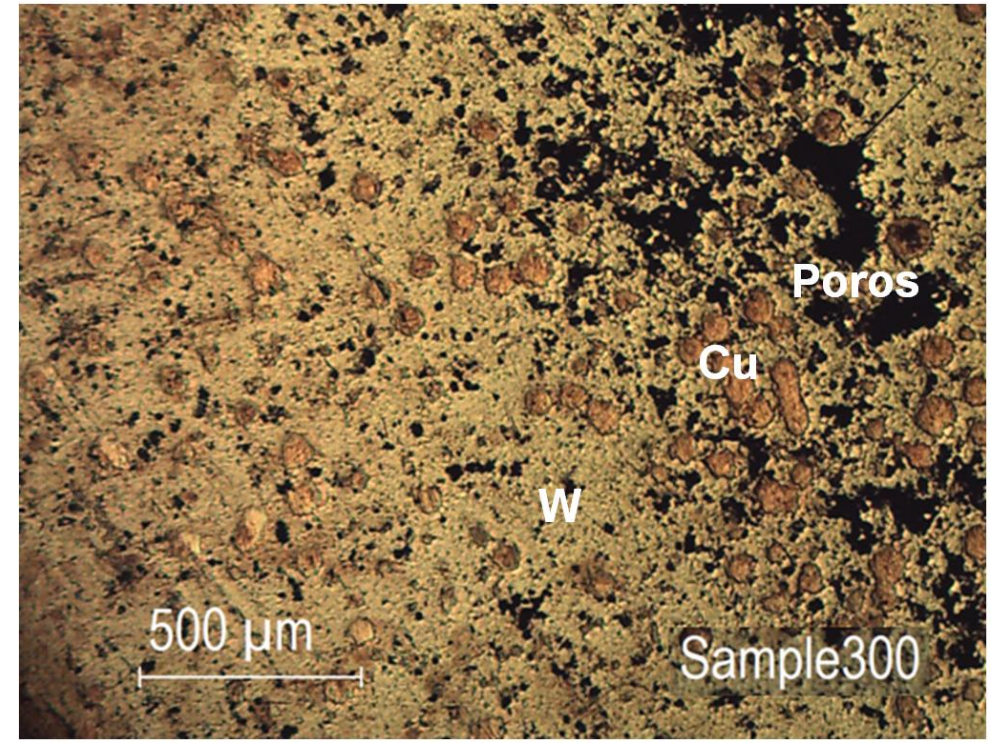

Fonte: criada pelo autor

Em um segundo processamento de sinterização utilizando o mesmo sistema de forno com fluxo de gás comercial protetiva $\left(80 \mathrm{~N}_{2} 20 \mathrm{H}_{2}\right)$, sob pressão de 1,0 atm resultando em sinterizados do sistema W-Cu na composição W20Cu que solidificaram com característica de corpo sólido e aspecto metálico como pode ser observado na figura 5.40 . 
Figura 5.40. Micrografia ótica da amostra W20Cu após a sinterização em forno com atmosfera $\left(80 \mathrm{~N}_{2} 2 \mathrm{H}_{2}\right)$ em forno industrial de esteira.

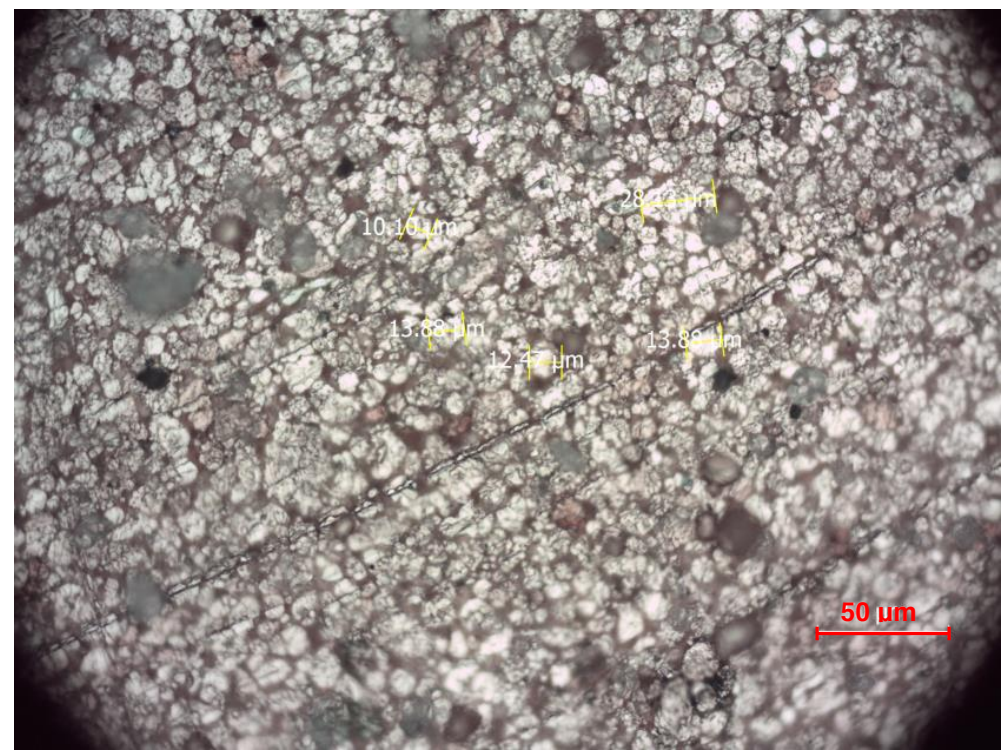

Fonte: criada pelo autor

A figura 5.41 ilustra a superfície da amostra do sinterizado com a composição $\mathrm{W} 10 \mathrm{Cu} 1,5 \mathrm{Ni}$, após a sinterização em forno industrial de esteira com atmosfera $\left(80 \mathrm{~N}_{2} 2 \mathrm{H}_{2}\right)$ onde pode ser observado oxidação superficial inferior quando comparada com as amostras obtidas em condição de atmosfera com fluxo do gás $90 \mathrm{~N}_{2} 10 \mathrm{H}_{2}$.

Figura 5.41. Micrografia ótica da amostra de mistura W10Cu1,5Ni após a sinterização em forno industrial esteira com atmosfera $\left(80 \mathrm{~N}_{2} 2 \mathrm{H}_{2}\right)$.

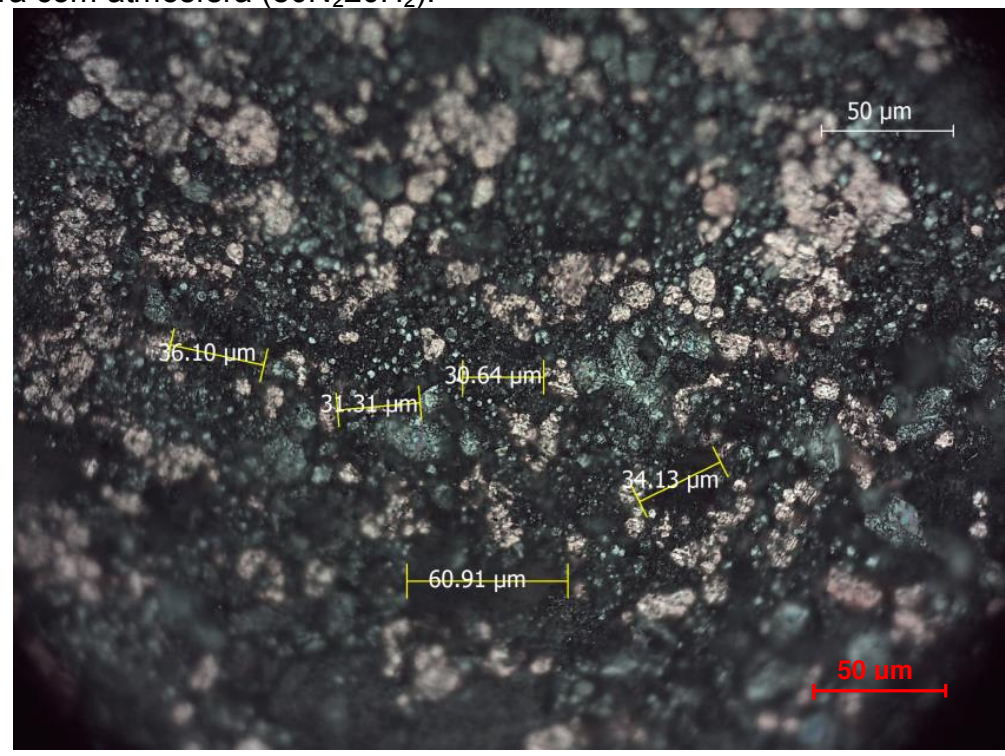

Fonte: criada pelo autor

A figura 5.42 ilustra a superfície do sinterizado em em forno industrial 
esteira com atmosfera $\left(80 \mathrm{~N}_{2} 20 \mathrm{H}_{2}\right)$ em com a composição W10Cu1Ni.

Figura 5.42 Micrografia ótica da amostra do sistema W10Cu1Ni após a sinterização em forno industrial esteira com atmosfera $\left(80 \mathrm{~N}_{2} 2 \mathrm{H}_{2}\right)$.

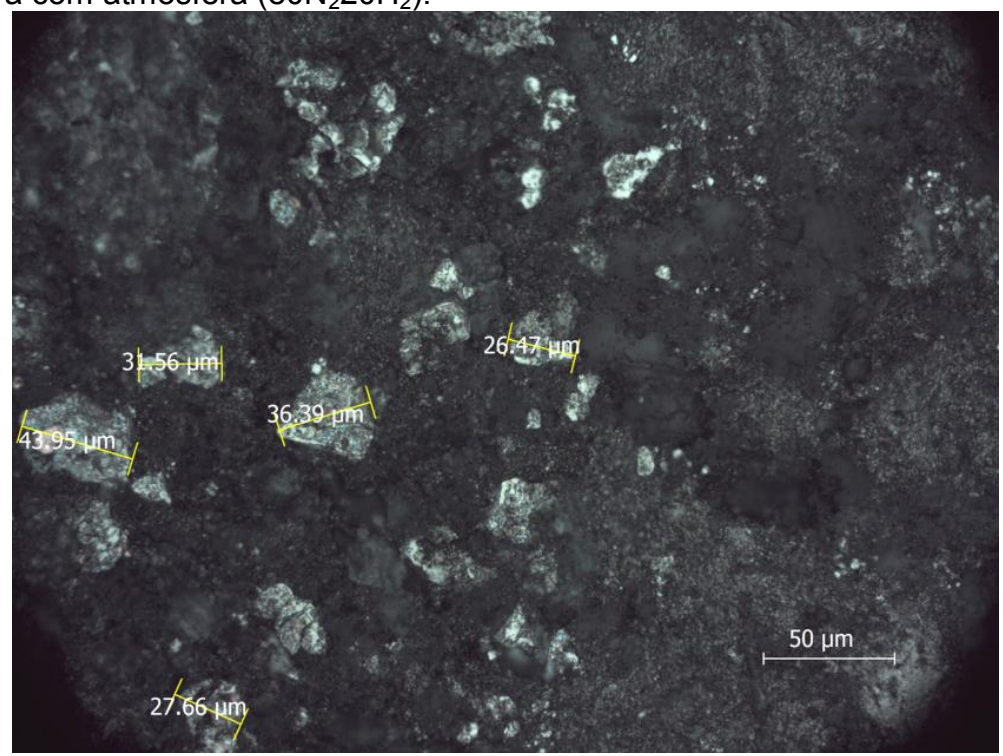

Fonte: criada pelo autor

Portanto, da comparação entre as amostras de composição W10Cu1,5Ni e W10Cu1Ni foi observado características de resistência mecânica semelhantes, porém a composição W10Cu1,5Ni apresenta densidade teórica de 18,1072 g.cm ${ }^{-3}$ e a composição W10Cu1Ni apresenta densidade teórica de $18,1591 \mathrm{~g} . \mathrm{cm}^{-3}$, sendo esta de maior densidade a mais indicada para material de blindagem contra radiação.

As amostras sinterizadas em forno resistivo convencional com atmosfera $\mathrm{Ar}$ ou em forno industrial de esteira com gás de composição comercial $\left(90 \mathrm{~N}_{2} 10 \mathrm{H}_{2}\right)$ ou atmosfera redutora $\left(80 \mathrm{~N}_{2} 20 \mathrm{H}_{2}\right)$ apresentaram elevado e moderado grau de oxidação.

\subsubsection{Fluxo de argônio (Ar)}

A micrografia ótica da figura 5.43 ilustra a superfície da amostra de composição $\mathrm{W} 10 \mathrm{Cu} 1 \mathrm{Ni}$, onde as partículas de tungstênio estão dispersas na liga CuNi. 
Figura 5.43 Micrografia ótica da amostra de mistura $\mathrm{W} 10 \mathrm{Cu} 1 \mathrm{Ni}$, após a sinterização forno industrial esteira com atmosfera $\left(80 \mathrm{~N}_{2} 2 \mathrm{H}_{2}\right)$.

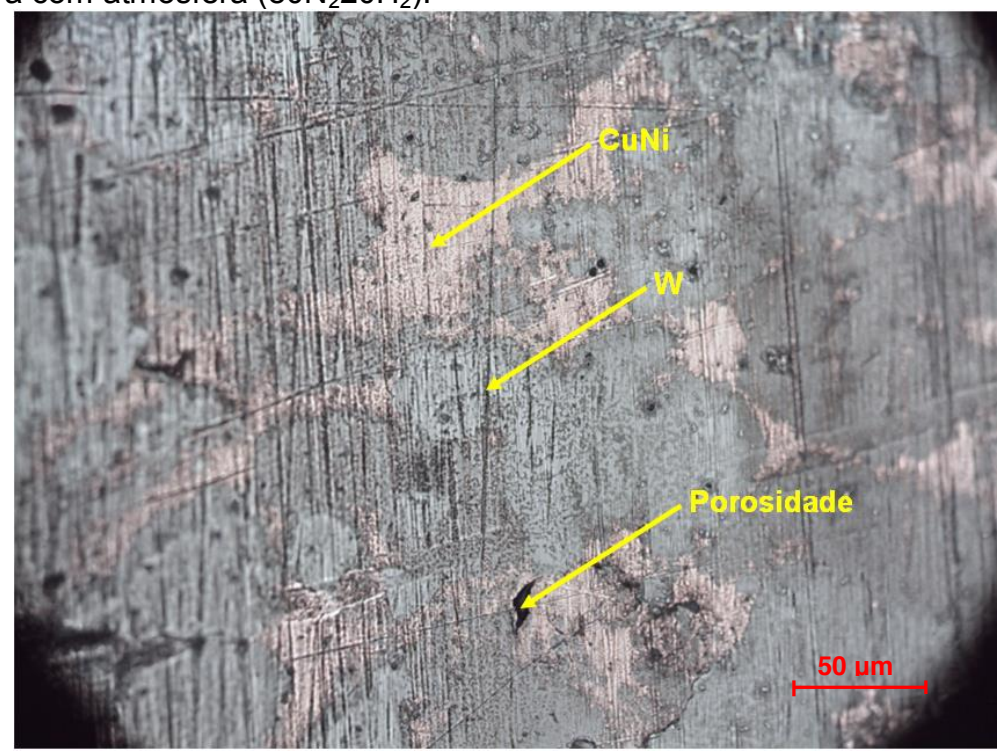

Fonte: criada pelo autor

A figura 5.44 mostra a imagem da micrografia MEV, com análise de uma região de interface onde ocorreu boa condição de formação e a difusão do intermetálico CuNi ancorando aglomerados de partículas do tungstênio $[21,23]$. $\mathrm{Na}$ imagem é possível observar o melhor preenchimento dos poros por ação da sinterização de fase líquida e o preenchimento volumétrico por partículas de tungstênio em fase sólida [22,23].

Figura 5.44 Micrografia MEV da amostra W10Cu1Ni apresentando a região da fase líquida CuNi (particulado fino) e da fase composta por particulados de tungstênio (particulado grosso).

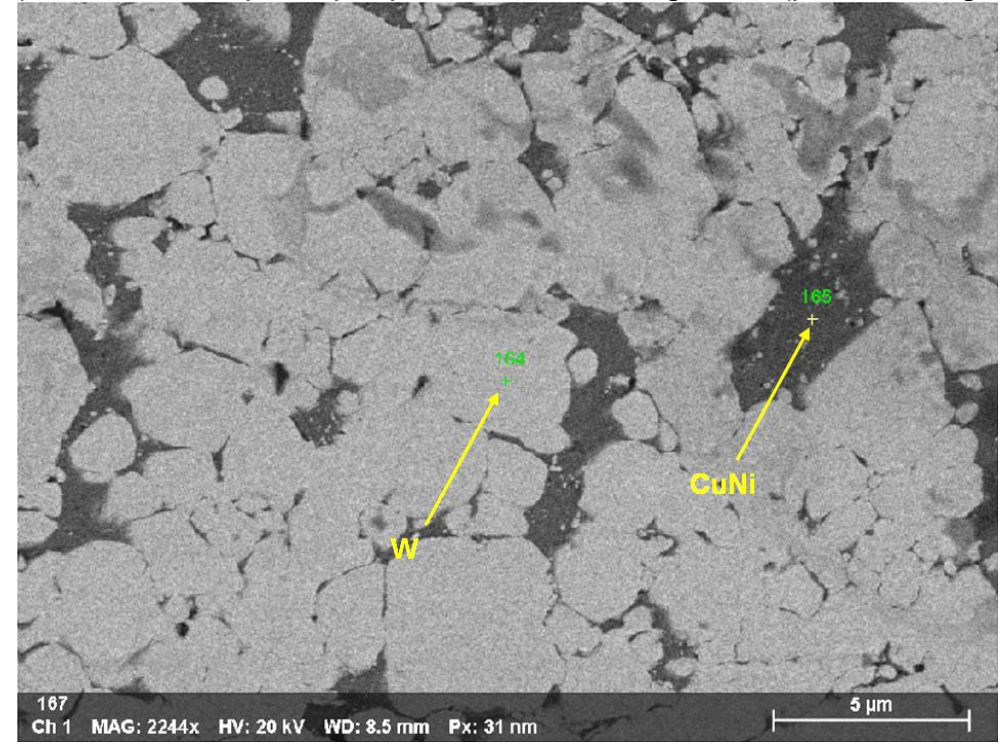

Fonte: criada pelo autor

Na figura 5.45 é apresentado o espectro de energia dispersiva (EDS) para 
o ponto I64, na região indicada por W na figura 5.44 , como sendo tungstênio e em destaque os picos de energia para o tungstênio $(Z=74)$ da camada eletrônica $M$ e $\mathrm{L}$, a correlação entre amplitude dos picos $\mathrm{M}$ dos gráficos de $\mathrm{W}$ que mostram as proporções em massa de tungstênio do compósito W10Cu1Ni.

Figura 5.45 Espectro de energia dispersiva (EDS) na região de tungstênio (W) da amostra W10Cu1Ni.

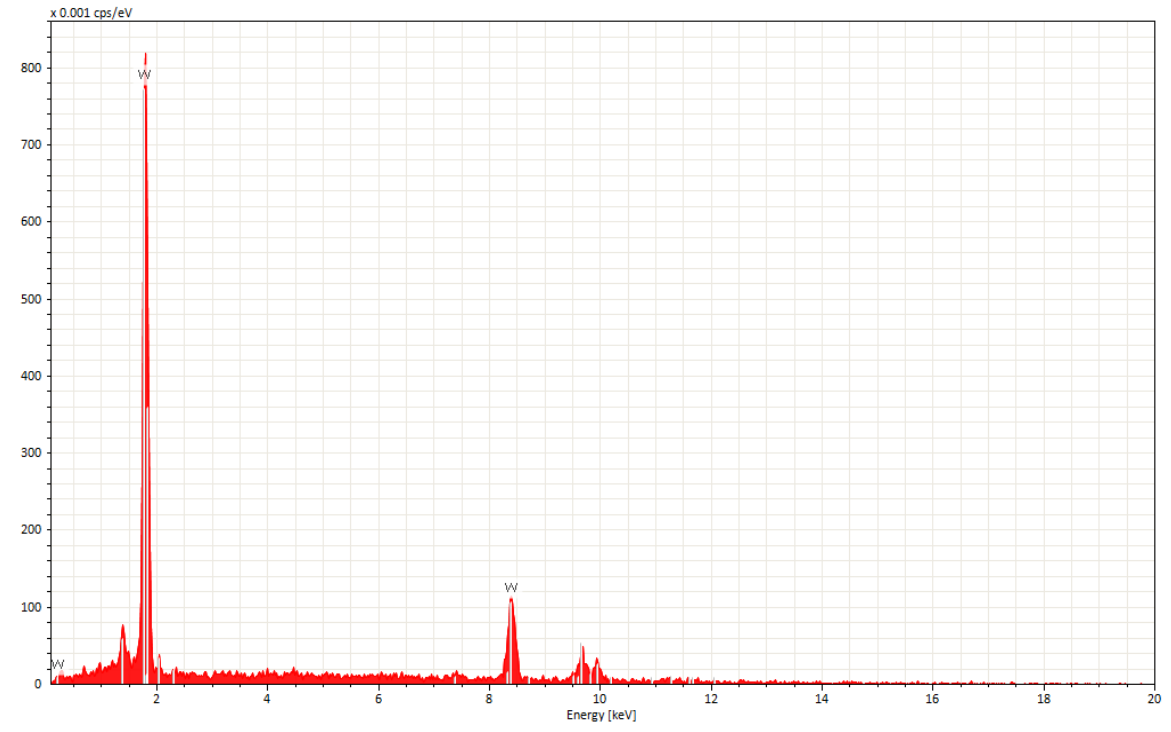

Fonte: criada pelo autor

Na figura 5.46 é apresentado o espectro de energia dispersiva (EDS) para o ponto 165 , da região, na figura 5.44 indicado como de presença do cobre-níquel (CuNi). No espectro as intensidades estão separadas por elemento e a intensidade dos picos são proporcionais a presença do elemento na composição em massa na região observada. Os picos de energia de transição da camada eletrônica $L$ para o cobre $(Z=29)$ e o níquel $(Z=28)$ quando sobrepostos indicam a possibilidade de formação da solução sólida CuNi nas proporções em massa do compósito W10Cu1Ni. É também possível observar picos do elemento tungstênio (W) inferindo que houve formação de difusão de cobre-níquel na superfície do tungstênio (W). Na região assinalada por 165 na figura 5.44 é possível observar a presença de partículas finas do elemento tungstênio. 
Figura 5.46 Espectro de energia dispersiva (EDS) na região do cobre-níquel (CuNi) da amostra W10Cu1Ni.

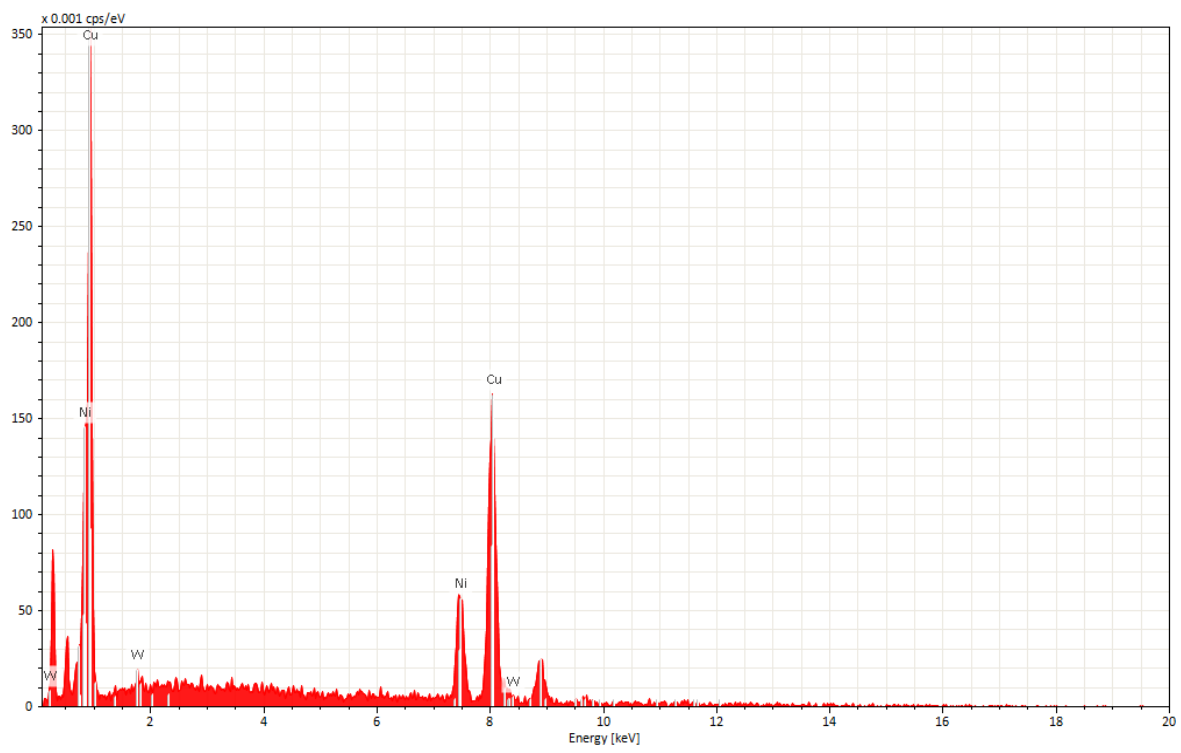

Fonte: criada pelo autor

A tabela 5.18 apresenta os valores obtidos por técnica de varredura por energia dispersiva (EDS) para os elementos químicos presentes na região indicada da amostra W10Cu1Ni da figura 5.44. O indicador de contagens por elemento na área de varredura de feixe (I-65) indicam a presença de 1,04\% do elemento tungstênio, presença de $72,58 \%$ de cobre e $26,38 \%$ do níquel.

Tabela 5.18 Dados de composição química por EDS da região CuNi da amostra W10Cu1Ni.

\begin{tabular}{lccccc}
\hline Elemento & $\begin{array}{c}\text { Número } \\
\text { atômico } \\
(\mathrm{N})\end{array}$ & $\begin{array}{c}\text { Principais } \\
\text { componentes } \\
\text { presentes } \\
(\mathrm{kcps})\end{array}$ & $\begin{array}{c}\text { Massa } \\
\text { normalizada } \\
(\% \text { massa) }\end{array}$ & $\begin{array}{c}\text { Erro } \\
\text { absoluto } \\
(\%)\end{array}$ & $\begin{array}{c}\text { Erro } \\
\text { relativo } \\
(\%)\end{array}$ \\
\hline $\mathrm{W}$ & 74 & 45 & 1,91 & 17,23 & 0,28 \\
\hline $\mathrm{Cu}$ & 29 & 3134 & 77,70 & 3,39 & 2,23 \\
\hline $\mathrm{Ni}$ & 28 & 1139 & 21,01 & 4,36 & 0,78 \\
\hline
\end{tabular}

Fonte: criada por autor

A micrografia óptica da figura 5.47 ilustra a superfície da amostra de composição W8Cu1Ni onde as partículas de tungstênio estão dispersas na liga CuNi. 
Figura 5.47 Micrografia ótica da superfície da amostra de composição W8Cu1Ni.

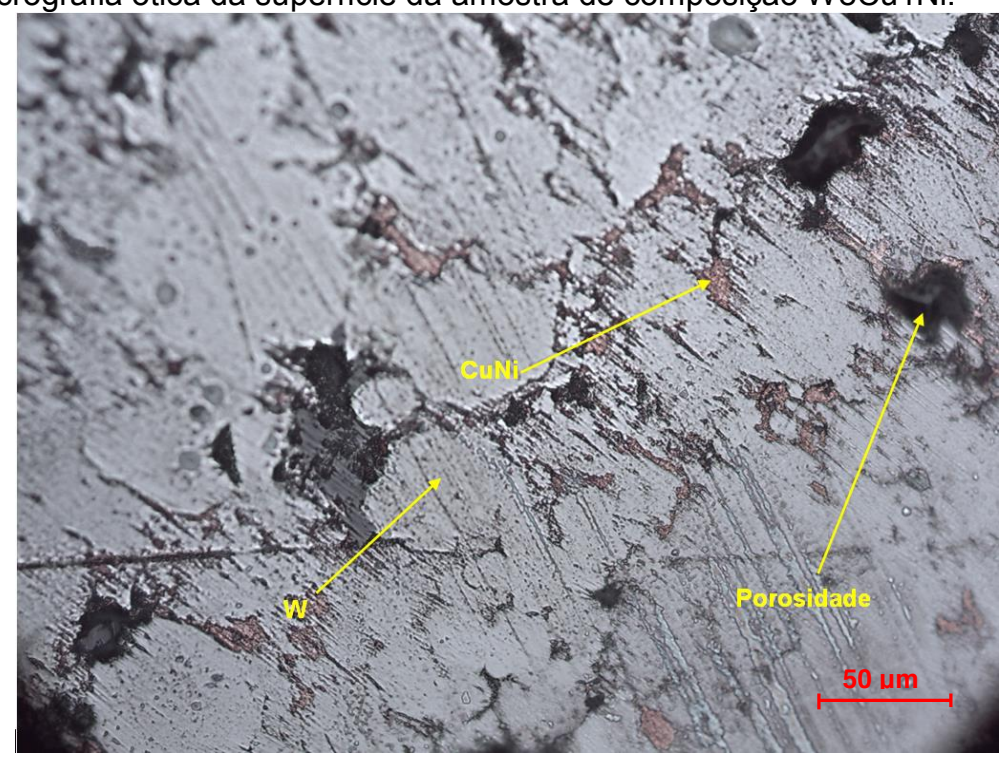

Fonte: criada de autor

A figura 5.48 mostra a imagem da micrografia MEV com análise de uma região de interface, em que ocorreu boa condição de formação e a difusão do intermetálico CuNi, ancorando aglomerados de partículas do tungstênio $[21,23]$. $\mathrm{Na}$ imagem é possível observar o melhor preenchimento dos poros por ação da sinterização de fase líquida e o preenchimento volumétrico por partículas de tungstênio em fase sólida [22,23].

Figura 5.48 Micrografia MEV da amostra W8Cu1Ni representando as regiões da fase líquida CuNi (cinza escuro) e da fase composta por particulados grossos e aglometrados finos de tungstênio (cinza claro).

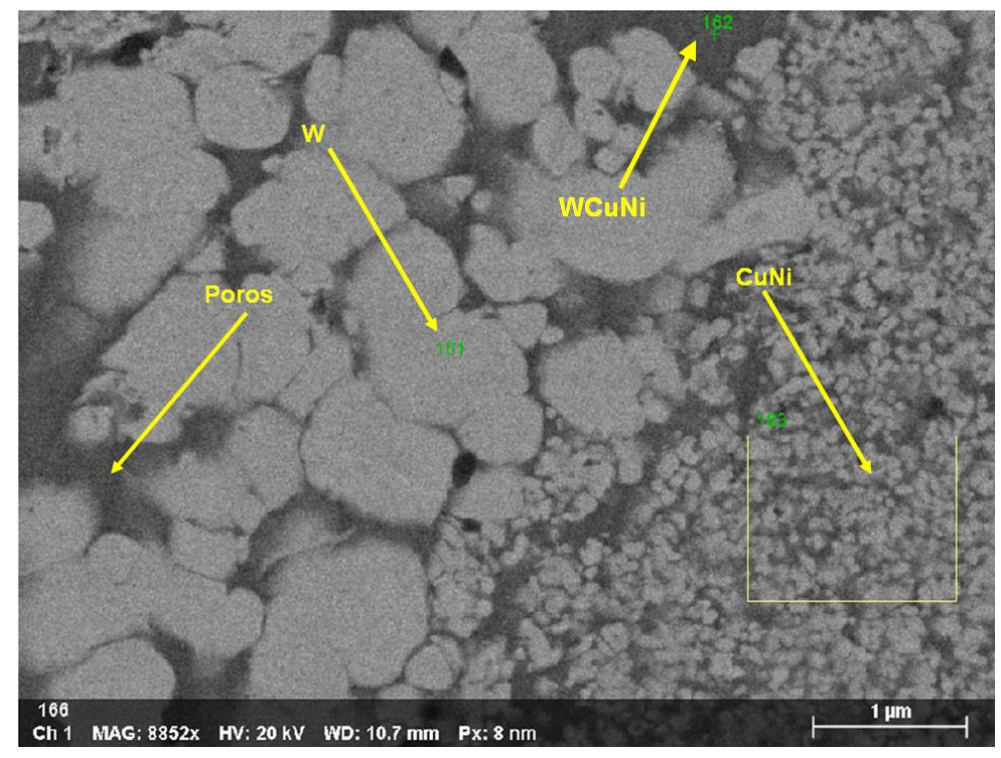

Fonte: criada por autor

Na figura 5.49 é apresentado o espectro de energia dispersiva (EDS) para

a figura 5.48, o ponto 162 marca a região da composição WCuNi e o ponto I63 
marca a região da composição CuNi. Na figura 5.49, os picos de energia da transição de camada eletrônica $L$ para o cobre $(Z=29)$ e níquel $(Z=28)$,quando sobrepostos indicam a possibilidade de formação da solução sólida $\mathrm{CuNi}$,nas proporções em massa, do composto W8Cu1Ni para a região CuNi da figura 5.48 (contraste cinza escuro).

Figura 5.49 Espectro de energia dispersiva (EDS) na região CuNi da amostra W8Cu1Ni.

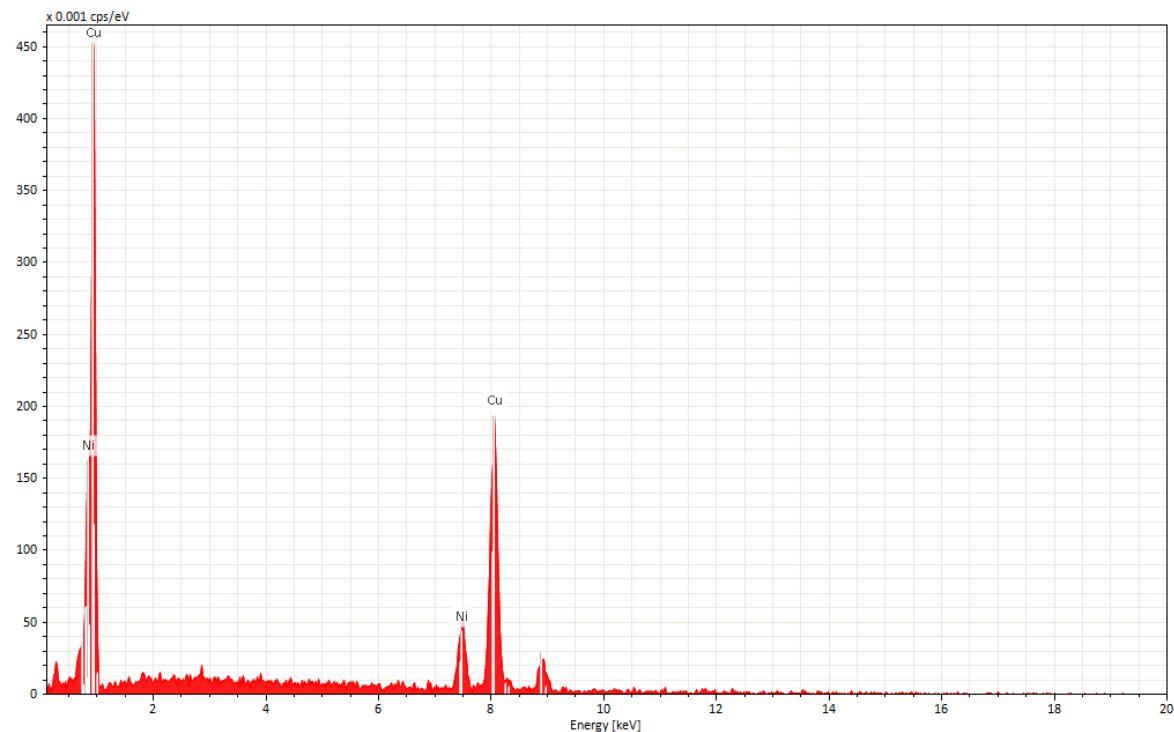

Fonte: criada pelo autor

Na figura 5.50 é apresentado o espectro de energia dispersiva (EDS) para a região figura 5.48 no ponto 161 demarcando o elemento tungstênio (W). $\mathrm{Na}$ figura 5.50 é importante destacar os picos de energia para o tungstênio $(Z=74)$ da camada eletrônica $M, L$ e a correlação entre amplitude dos picos W que indicam proporções de massa do tungstênio no compósito $\mathrm{W} 8 \mathrm{Cu} 1 \mathrm{Ni}$. A região da figura 5.48 (cinza claro) representa o elemento tungstênio (W) em separado da região (cinza escuro) indicando que não houve difusão de liga Cu-Ni sobre o elemento tungstênio $(\mathrm{W})$. 
Figura 5.50 Espectro de energia dispersiva (EDS) na região do tungstênio (W) da amostra W8Cu1Ni.

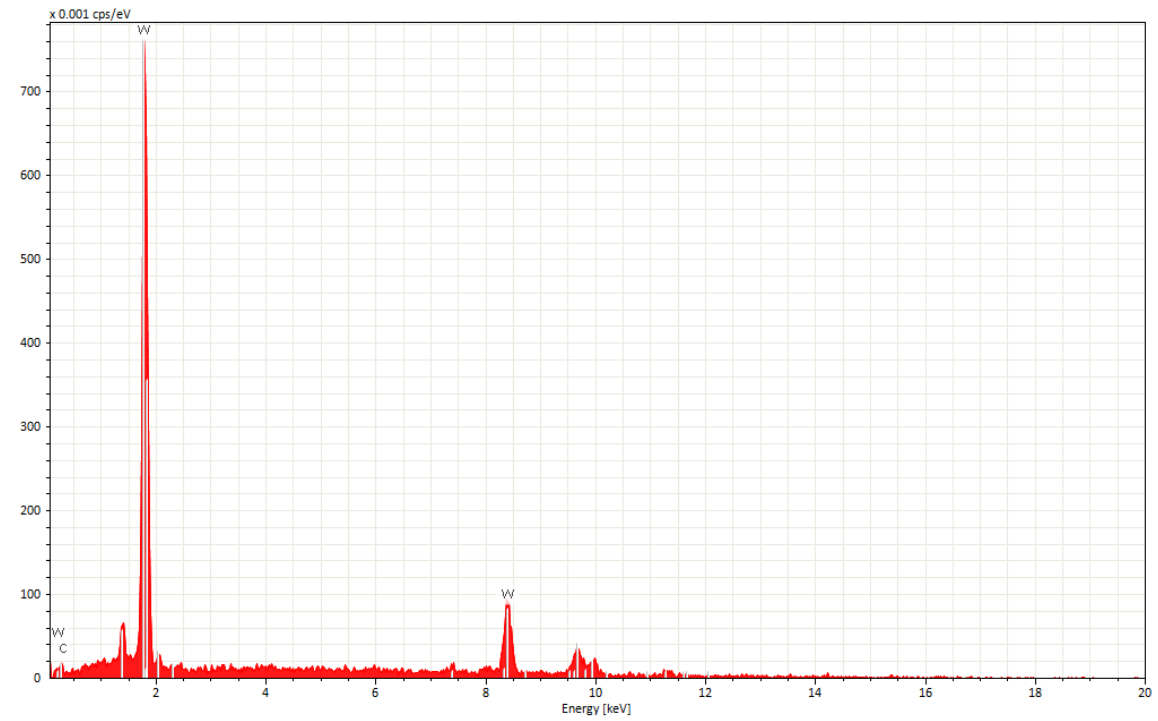

Fonte: criada por autor

A tabela 5.19 apresenta os valores relativos para os elementos químicos presentes na região indicada da amostra W8Cu1Ni. O indicador de contagens por elemento na área de varredura de feixe (I-61) indicam a presença de $91,07 \%$ do elemento tungstênio, presença de $7,42 \%$ de cobre e $1,51 \%$ do níquel.

Tabela 5.19 Dados de composição química por EDS da amostra W8Cu1Ni.

\begin{tabular}{llllll}
\hline Elemento & $\begin{array}{l}\text { Número } \\
\text { atômico } \\
(\mathrm{N})\end{array}$ & $\begin{array}{l}\text { Principais } \\
\text { componentes } \\
\text { presentes } \\
(\mathrm{kcps})\end{array}$ & $\begin{array}{l}\text { Massa } \\
\text { normalizada } \\
(\% \text { massa) }\end{array}$ & $\begin{array}{l}\text { Erro } \\
\text { absoluto } \\
(\%)\end{array}$ & $\begin{array}{l}\text { Erro } \\
\text { relativo } \\
(\%)\end{array}$ \\
\hline $\mathrm{W}$ & 74 & 12838 & 91,72 & 8,96 & 5,23 \\
\hline $\mathrm{Cu}$ & 29 & 1046 & 7,23 & 7,89 & 3,06 \\
\hline $\mathrm{Ni}$ & 28 & 213 & 1,96 & 2,15 & 2,51 \\
\hline
\end{tabular}

Fonte: criada por autor

A micrografia ótica da figura 5.51 ilustra a superfície da amostra de composição $\mathrm{W} 6 \mathrm{Cu} 1 \mathrm{Ni}$, representando as partículas de tungstênio dispersas na liga $\mathrm{CuNi}$ e ilhas da liga $\mathrm{CuNi}$, dispersas na superfície, com a porosidade representada pelos pontos em preto. 
Figura 5.51 Micrografia ótica da superfície da amostra de composição W6Cu1Ni.

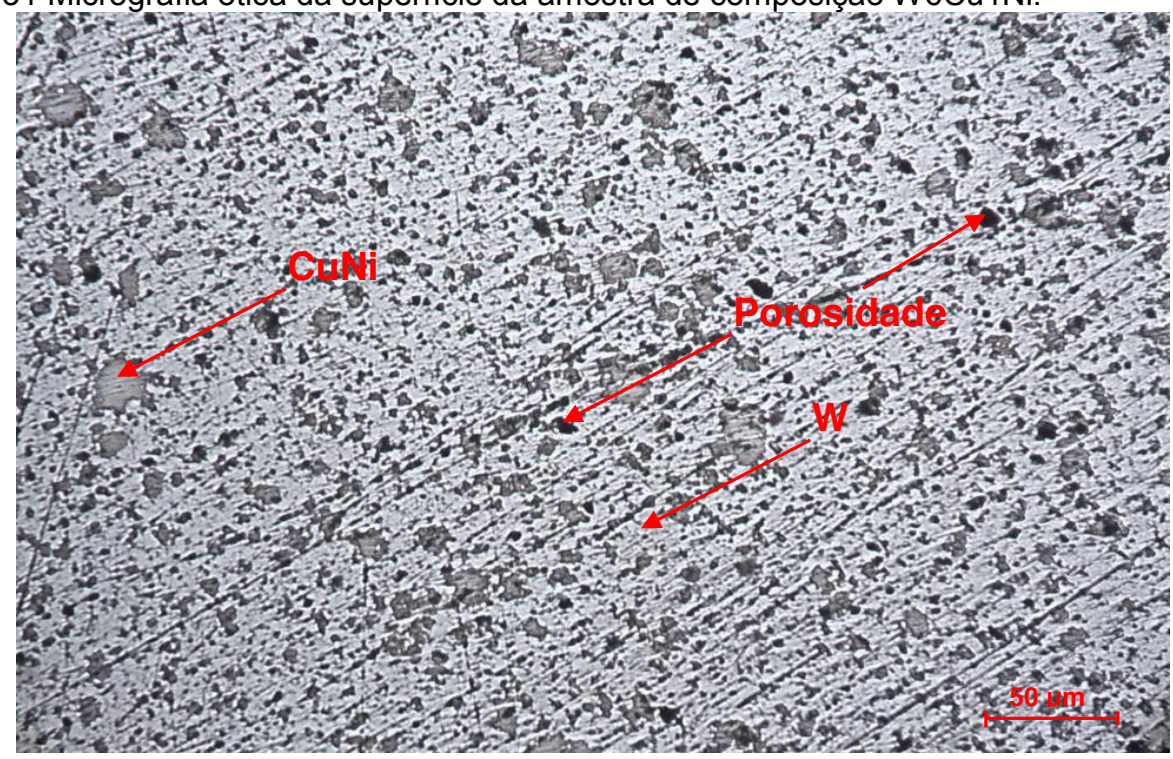

Fonte: criada por autor

A figura 5.52 mostra a micrografia MEV com análise de uma região de interface onde ocorreu a formação e difusão da liga CuNi, ancorando aglomerados de partículas do tungstênio [21]. Na imagem é possível observar o melhor preenchimento dos poros por ação da sinterização de fase líquida e o preenchimento volumétrico por partículas de tungstênio em fase sólida $[22,23]$.

Figura 5.52 Micrografia MEV da amostra da mistura W6Cu1Ni na região da fase líquida CuNi (região escura) e da fase composta por particulados de tungstênio (região clara).

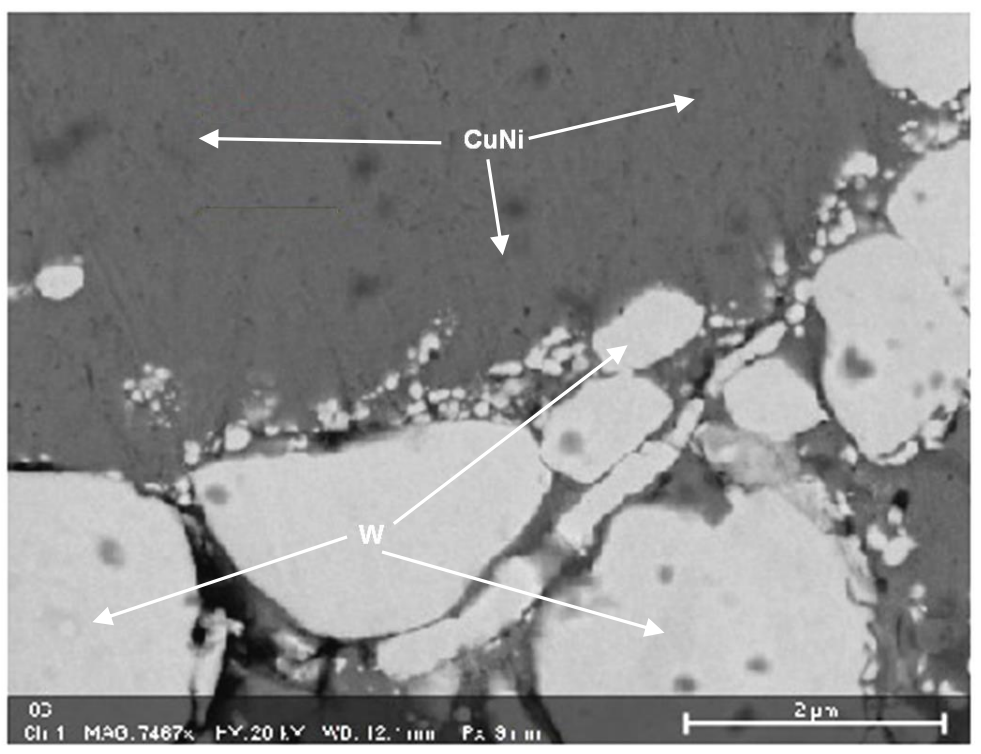

Fonte: criada por autor

Na figura 5.53 é apresentado o espectro de energia dispersiva (EDS) para as regiões indicadas como $\mathrm{CuNi}$ na figura 5.52. É importante destacar que, 
embora semiquantitativo, os picos de energia da camada eletrônica $L$ para o cobre $(Z=29)$ e níquel $(Z=28)$ quando sobrepostos indicam a possibilidade de formação da solução sólida $\mathrm{CuNi}$, nas proporções em massa do composto W6Cu1Ni para a região CuNi da figura 5.52 (cinza escuro).

Figura 5.53 Espectro de energia dispersiva (EDS) na região CuNi da amostra W6Cu1Ni.

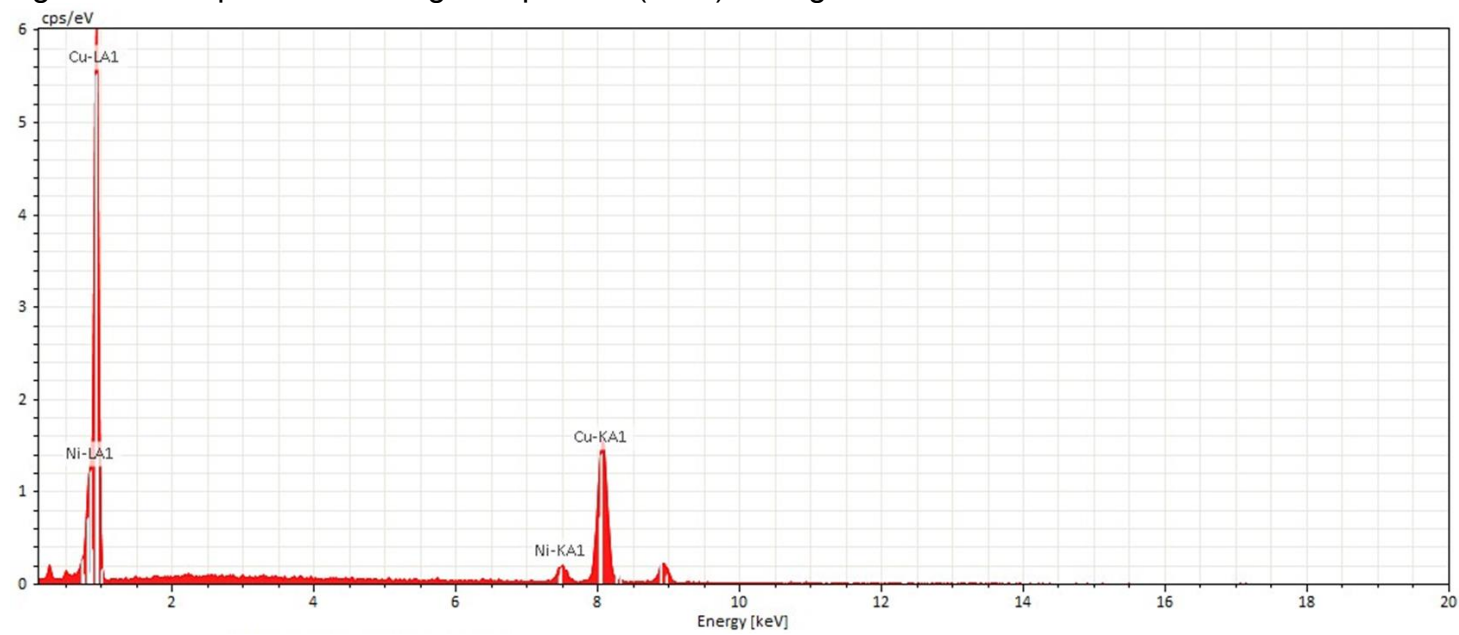

Fonte: criada por autor

Na figura 5.54 é apresentado espectro de energia dispersiva (EDS) para a região indicada, como tungstênio (W), na figura 5.52. Ainda na figura 5.52 é importante destacar os picos transição de energia para o tungstênio $(Z=74)$, da camada eletrônica M e L a correlação entre intensidades dos picos indicam a presença em massa de tungstênio (W) nas proporções do compósito W6Cu1Ni. As regiões estão separadas por elemento na mesma figura. Em cinza escuro (CuNi) indicado que houve difusão da liga Cobre-Níquel sobre as partículas de tungstênio com formação de ancoragem dos aglomerados de tungstênio em corpo sólido. 
Figura 5.54 Espectro de energia dispersiva (EDS) na região do tungstênio (W) da amostra W6Cu1Ni

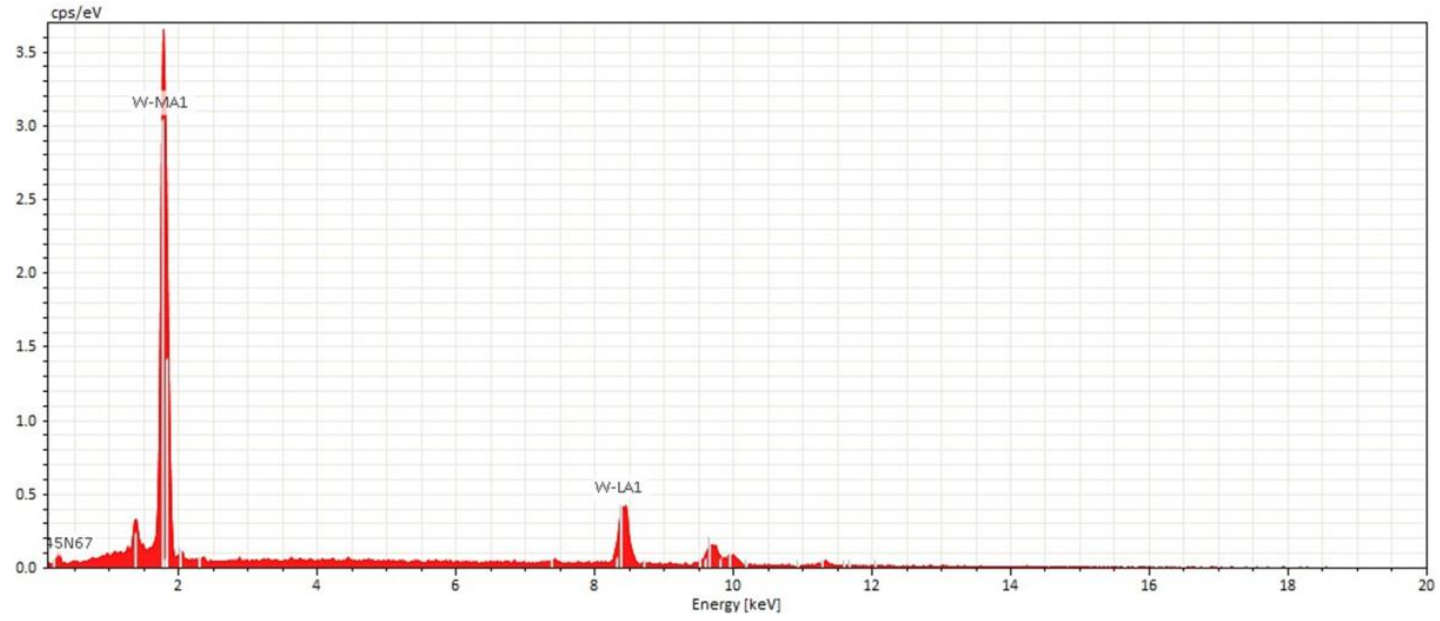

Fonte: criada por autor.

$\mathrm{Na}$ tabela 5.20, estão destacados os valores proporcionais em porcentagem dos elementos presentes na composição das amostras W6Cu1Ni. O indicador de contagens por elemento na área de varredura de feixe (W) indicam a presença de $91,88 \%$ do elemento tungstênio, presença de $6,67 \%$ de cobre e $1,45 \%$ do níquel.

Tabela 5.20 Dados de composição química por EDS da amostra W6Cu1Ni.

\begin{tabular}{llllll}
\hline Elemento & $\begin{array}{l}\text { Número } \\
\text { atômico } \\
(\mathrm{N})\end{array}$ & $\begin{array}{l}\text { Principais } \\
\text { componentes } \\
\text { presentes } \\
(\mathrm{kcps})\end{array}$ & $\begin{array}{l}\text { Massa } \\
\text { normalizada } \\
(\% \text { massa })\end{array}$ & $\begin{array}{l}\text { Erro } \\
\text { absoluto } \\
(\%)\end{array}$ & $\begin{array}{l}\text { Erro } \\
\text { relativo } \\
(\%)\end{array}$ \\
\hline$(\mathrm{W})$ & 74 & 11192 & 93,22 & 9,01 & 4,88 \\
\hline$(\mathrm{Cu})$ & 29 & 815 & 6,51 & 5,51 & 3,41 \\
\hline$(\mathrm{Ni})$ & 28 & 177 & 0,27 & 1,73 & 2,55 \\
\hline
\end{tabular}

Fonte: criada por autor

\subsubsection{Vácuo}

Foi utilizado um forno tubular com auxílio de uma bomba de vácuo mecânica, para a retirada do ar atmosférico e onde é adicionado o gás hidrogênio $\left(\mathrm{H}_{2}\right)$ como atmosfera redutora na pressão de $0,8 \mathrm{~atm}$. A rampa de aquecimento foi de $6,5{ }^{\circ} \mathrm{C} / \mathrm{min}$ e plataforma na temperatura de $1.100{ }^{\circ} \mathrm{C}$ por $180 \mathrm{~min}$. Nestes parâmetros foram sinterizadas as composições W10Cu1,5Ni, W10Cu1Ni, W8Cu1Ni, W6Cu1Ni, W1Ni e W0,5Ni. Após a sinterização destas amostras 
houveram a apresentação de características mecânicas com aspectos de corpo sólido, boa resistência na ancoragem das partículas de tungstênio.

Nestas condições, as composições do sistema W-Cu-Ni apresentaram densidades inferiores àquelas obtidas em sinterização nos fornos tubulares com fluxo de arraste. Ao comparar a resistência por desgaste, por abrasagem em lixamento, entre as amostras de composição W1Ni e W0,5Ni as amostras W1 Ni apresentaram maior resistência e características de sinterizado sólido e foram analisadas por microscopia óptica conforme ilustra a figura 5.55 para serem utilizadas em ensaios de atenuação.

Figura 5.55 Micrografia óptica na região de borda da amostra de composição W1Ni.

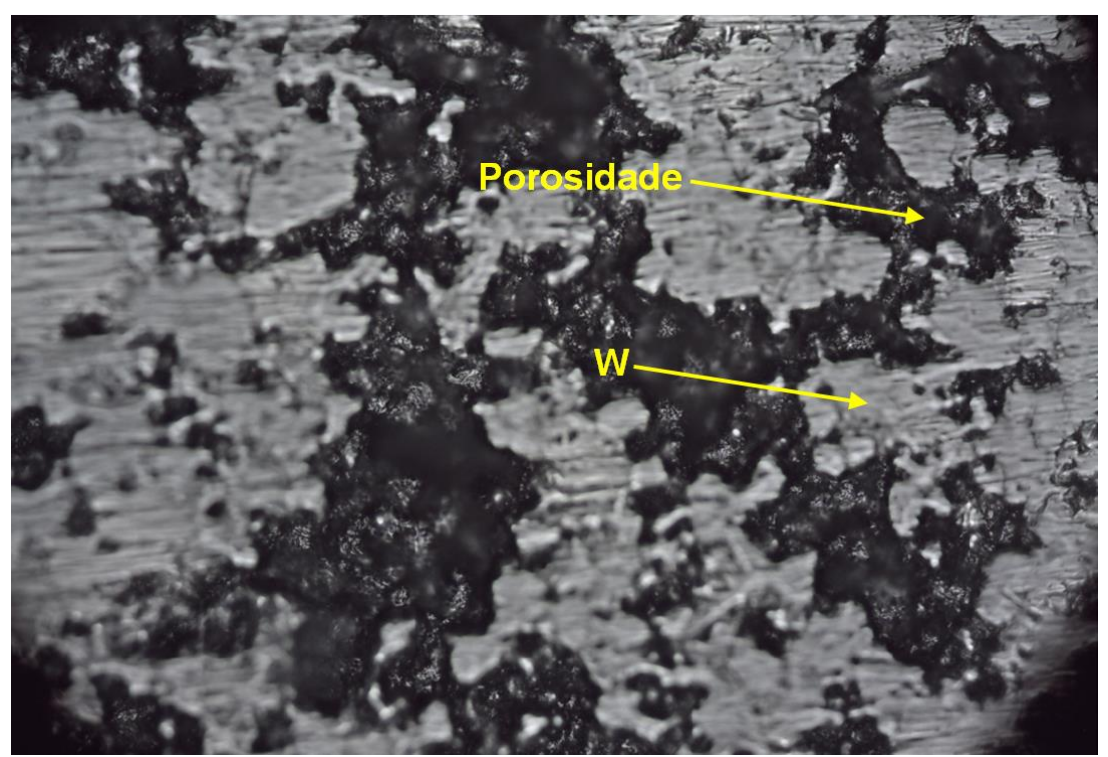

Fonte: criada por autor

$\mathrm{Na}$ figura 5.56 é apresentada a micrografia MEV da amostra W1Ni destacando a região de borda, em que é observado que as partículas de tungstênio (W) da superficie estão molhadas pelo níquel que solubilizou [70]. A superfície da amostra apresentou pequenas fissuras e alta porosidade que podem ser atribuídas a baixa pressão de compactação e ao efeito relaxamento (springback). A amostra apresentou melhor ancoragem e formação do compósito sólido na região de borda. Por ação da sinterização, com fase líquida, as partículas de níquel fundido difundiram melhor na região de borda da amostra, quando comparada com a região central. 
Figura 5.56 Micrografia MEV da região de borda da amostra de composição W1Ni.

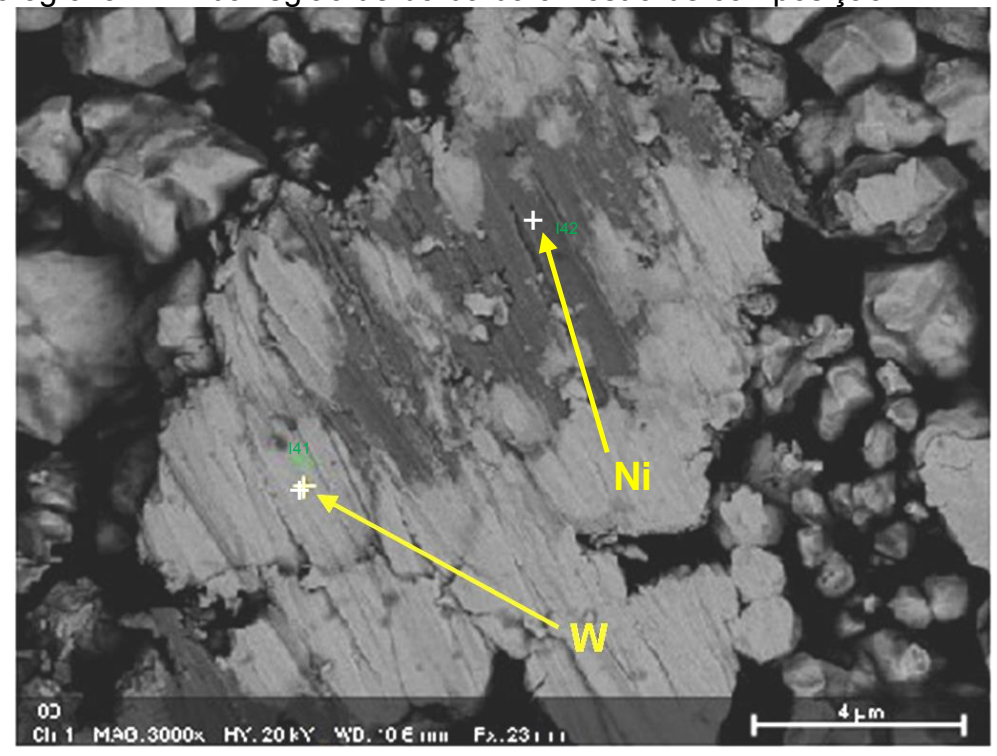

Fonte: criada por autor

A micrografia MEV da figura 5.56 mostra a distribuição irregular do fundente níquel, entre as partículas do tungstênio e existência de alto índice de porosidade. A alta porosidade pode ser verificada pelo cálculo da densidade geométrica que resultou em 10,28 g. $\mathrm{cm}^{-3}$, quando o valor teórico é de $17,6 \mathrm{~g} . \mathrm{cm}^{-3}$. O baixo teor de níquel na composição W1Ni pode ser apontado como fator da baixa dispersão da fase líquida, na região central reduzindo a resistência mecânica. A figura 5.57 apresenta o espectro de EDS para a área 141 (W) indicada pela figura 5.56, na região de borda da amostra $\mathrm{W} 1 \mathrm{Ni}$. O resultado da análise do espectro de EDS indica que os picos M- $\alpha 1$ em 1,8 keV ultrapassam intensidade de $5,0 \mathrm{cps} / \mathrm{eV}$ e são de transição da energia característica do átomo de tungstênio. Os picos L- $\alpha 1$ são característicos do elemento níquel marcados em 1,4 keV com pico inferior a intensidade de 0,5 cps/ev para a transição da energia característica do elemento níquel e indicando proporcionalidade superior à presença de 1,0\% em massa de níquel na região.

Figura 5.57 Espectro de energia dispersiva (EDS) mostrando a composição química na região de borda da amostra W1Ni. 


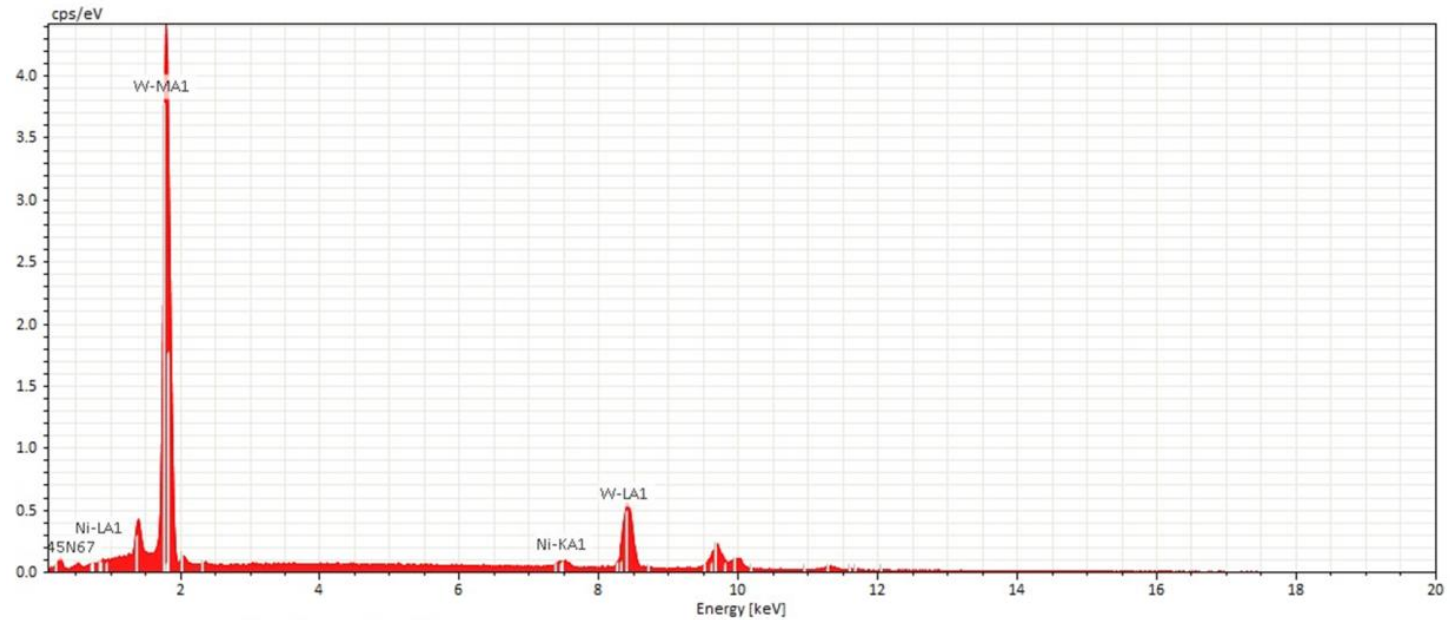

Fonte: criada de autor

A tabela 5.21 apresenta os dados quantitativos para o espectro EDS da figura 5.57 e os valores obtidos para os elementos químicos, na região de borda em I41 da amostra W1Ni. Os valores indicam que no ponto existe a presença de $99,29 \%$ tungstênio e $0,71 \%$ do elemento níquel.

Tabela 5.21 Dados de composição química por EDS da região de tungstênio (W) da amostra W1Ni.

\begin{tabular}{llllll}
\hline Elemento & $\begin{array}{l}\text { Número } \\
\text { atômico } \\
(\mathrm{N})\end{array}$ & $\begin{array}{l}\text { Principais } \\
\text { componentes } \\
\text { presentes } \\
(\mathrm{kcps})\end{array}$ & $\begin{array}{l}\text { Massa } \\
\text { normalizada } \\
(\% \text { massa) }\end{array}$ & $\begin{array}{l}\text { Erro } \\
\text { absoluto } \\
(\%)\end{array}$ & $\begin{array}{l}\text { Erro } \\
\text { relativo } \\
(\%)\end{array}$ \\
\hline$(\mathrm{W})$ & 74 & 11576 & 99,29 & 1,39 & 0,88 \\
\hline$(\mathrm{Ni})$ & 28 & 9 & 0,71 & 8,73 & 3,72 \\
\hline
\end{tabular}

Fonte: criada de autor

A figura 5.58 mostra o espectro de EDS na região de borda da amostra $\mathrm{W} 1 \mathrm{Ni}$, detalhando o espectro de energia sobre o ponto 142 na figura 5.56. O espectro de EDS indica os picos M- 1 em 1,8 keV ultrapassaram a intensidade de $1,0 \mathrm{cps} / \mathrm{ev}$ e são da transição de energia característica da camada do elemento tungstênio. Os picos L-a1 em 1,4 keV estão com intensidade próximo de 2.0 cps/ev e são da transição de energia característica da camada do elemento níquel.

Figura 5.58 Espectro de energia dispersiva (EDS) representando a região de predominância do níquel sobre a amostra da mistura W1Ni. 


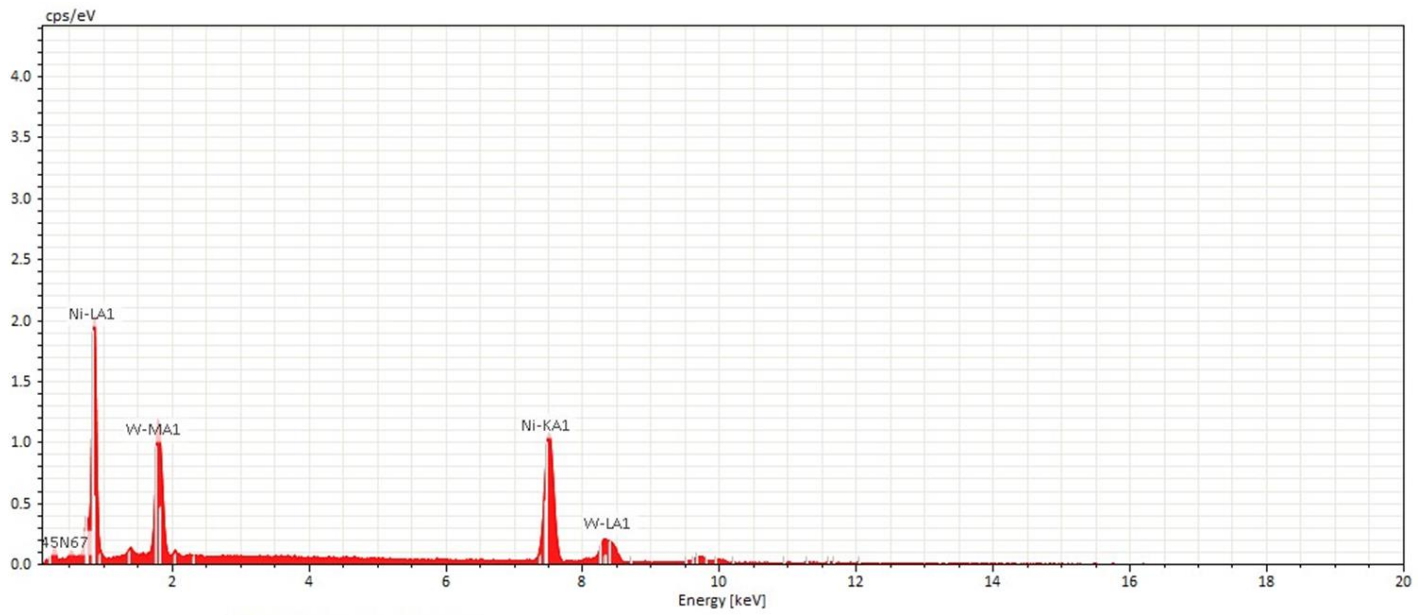

Fonte: criada de autor

$\mathrm{Na}$ tabela 5.22 estão representando os dados quantitativos por EDS dos valores obtidos para a presença dos elementos químicos no material caracterizado na região central da amostra W1Ni, ilustrada na figura 5.58 , sobre a superfície de predominância do níquel. Os valores indicam que no ponto existe a presença de $10,09 \%$ do elemento tungstênio (W) e a presença de $89,91 \%$ elemento níquel.

Tabela 5.22 Dados por EDS de composição química da amostra W1Ni na região de predominância de níquel (142).

\begin{tabular}{lllllll}
\hline Elemento & $\begin{array}{l}\text { Número } \\
\text { atômico } \\
(\mathrm{N})\end{array}$ & $\begin{array}{l}\text { Principais } \\
\text { componentes } \\
\text { presentes } \\
(\mathrm{kcps})\end{array}$ & $\begin{array}{l}\text { Massa } \\
\text { normalizada } \\
(\% \text { massa })\end{array}$ & $\begin{array}{l}\text { Composição } \\
\text { em átomos } \\
(\%)\end{array}$ & $\begin{array}{l}\text { Erro } \\
\text { absoluto } \\
(\%)\end{array}$ & $\begin{array}{l}\text { Erro } \\
\text { relativo } \\
(\%)\end{array}$ \\
\hline$(\mathrm{W})$ & 74 & 4709 & 20,38 & 10.09 & 2,17 & 3,23 \\
\hline$(\mathrm{Ni})$ & 28 & 18391 & 79,62 & 89.91 & 5,33 & 2,79 \\
\hline
\end{tabular}

Fonte: criada de autor

As amostras obtidas para o sistema W-Ni apresentaram baixa resistência nos aglomerados de tungstênio. As amostras do sistema W-Cu apresentaram oxidação superficial e em volume degradando da forma sólida, ocorrendo desaglomeração por perda da junção entre os particulados de tungstênio por ação da oxidação entre as partículas de tungstênio e a ancoragem pelo sólido de cobre obtido da sinterização com fase líquida. As misturas W8Cu1Ni (figura 5.47) e W6Cu1Ni (figura 5.51) do compactado a verde em pressão de $450 \mathrm{MPa}$ apresentaram resistência mecânica de sólido, enquanto as amostras de mistura 
W10Cu1Ni em mesma pressão fragilizaram. As mesmas composições em massa em pressão de $650 \mathrm{Mpa}$, resultaram em amostras de melhor resistência mecânica e houve consolidação do compactado em sinterizado sólido. As amostras de composição W8Cu1Ni e W6Cu1Ni que foram sinterizadas em forno tubular com atmosfera de $1 \mathrm{~atm}$ sob fluxo de argônio de $600 \mathrm{~mL} / \mathrm{min}$ a rampa de aquecimento usada foi de $23,3{ }^{\circ} \mathrm{C} / \mathrm{min}$, até atingir a temperatura de $1.400{ }^{\circ} \mathrm{C}$. O patamar de $1400{ }^{\circ} \mathrm{C}$ foi mantido por 240 min e a taxa de resfriamento exponencial ambiente até atingir $38^{\circ} \mathrm{C}$, mantido o fluxo de gás argônio resultaram em amostras com resistência meânica, dureza e densidade que atendem a necessidade para material de atenuação da radiação.

\subsection{Ensaios de microdureza Vickers}

As características finais de um material estão associadas às determinações de projeto e o desempenho nas funções depende das suas propriedades físicoquímicas $[137,140]$. As propriedades de resistência mecânica ao impacto foi obtido através de ensaios de microdureza Vickers. A figura 5.59 ilustra os pontos onde foram feitos os ensaios de dureza [141].

Figura 5.59 Regiões utilizadas para ensaios de microdureza Vickers na superfície e na região do corte transversa I- AB das amostras das misturas do sistema $\mathrm{W}-\mathrm{Cu}-\mathrm{Ni}$.
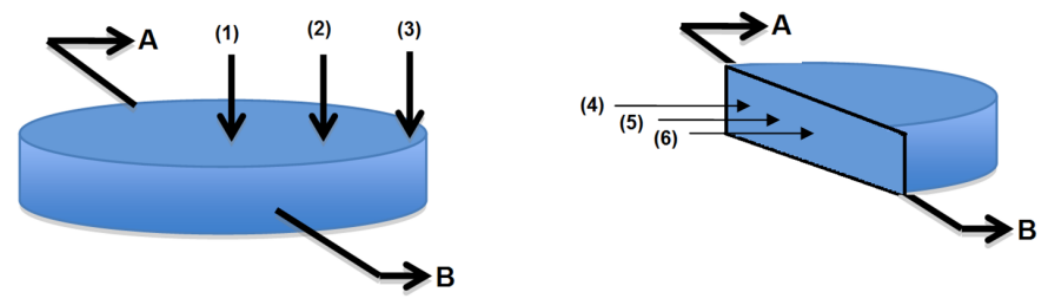

Fonte: criada de autor

Para os ensaios de microdureza foi usado carga de $25 \mathrm{~g}(98,07 \mathrm{mN})$. Os valores de microdureza obtidos para as amostras de misturas sinterizadas puderam ser comparados com os valores obtido na amostra padrão de referência de tungstênio. Os resultados são apresentados na tabela 5.23 . 
Tabela 5.23 Dados dos valores de microdureza Vickers obtido nos ensaios de laboratório para as amostras de misturas de sinterizados do sistema W-Cu-Ni.

\begin{tabular}{|c|c|c|c|c|c|c|c|c|}
\hline \multirow{2}{*}{ Amostras } & \multirow{2}{*}{$\begin{array}{l}\text { Densidade } \\
\text { geométrica } \\
\text { média } \\
\text { calculada } \\
\left(\mathrm{g} . \mathrm{cm}^{-3}\right)\end{array}$} & \multicolumn{6}{|c|}{ Microdureza por região nas amostras } & \multirow[b]{2}{*}{$\overline{\mu H V}$} \\
\hline & & (1) & (2) & (3) & $(4)$ & (5) & (6) & \\
\hline $\begin{array}{l}\text { Tungstênio } \\
99,9 \% \text { (Ref.) }\end{array}$ & 19,21 & 579,3 & 499,7 & 532,4 & 551,8 & 562,3 & 597,2 & 553,8 \\
\hline W10Cu1Ni & 13,00 & 237,2 & 249,5 & 178,9 & 197,4 & 135,8 & 191,3 & 198,3 \\
\hline W8Cu1Ni & 12,95 & 232,7 & 249,1 & 278,6 & 296,7 & 235,6 & 291,7 & 264,1 \\
\hline W6Cu1Ni & 13,58 & 318,3 & 327,7 & 257,2 & 298,1 & 226,7 & 391,8 & 303,3 \\
\hline W1Ni & 11.91 & 197,1 & 361,7 & 196,5 & 296,0 & 192,4 & 216,2 & 195,8 \\
\hline
\end{tabular}

Fonte: criada de autor

As variações nos valores de microdureza são em parte decorrentes de poros na superfície do material, microporos que apresentam abertura, próximo da superfície e heterogeneidade induzem informações com erro via ensaio [78,142]. A tabela 5.23 apresenta o teste de microdureza da amostra W1Ni com valores dispersivos entre si e não convergem com a dureza do metal tungstênio. A superfície polida da amostra apresenta partículas grandes do pó de tungstênio onde é possível, o apoio do identador e obter medida. Outras posições não oferecem superfície para o apoio do identador; em outras quando apoiado a pressão pode deslocar o particulado em função da alta porosidade do sinterizado [139]. A figura 5.60 ilustra as amostras de composição $\mathrm{W} 6 \mathrm{Cu} 1 \mathrm{Ni}$ as quais obtiveram resultados satisfatórios e melhor atendem as propriedades de ser compósito para a atenuação da radiação. Estas amostras foram compactadas em $450 \mathrm{MPa}$ e $650 \mathrm{MPa}$ e sinterizadas sob atmosfera de proteção com fluxo de argônio $600 \mathrm{~mL} / \mathrm{min}$ em temperatura de $1.400{ }^{\circ} \mathrm{C}$ atingindo densidade média de $13,00 \mathrm{~g} \cdot \mathrm{cm}^{-3}$.

Figura 5.60 Amostra W6Cu1Ni (a) como sinterizada (b) seção de corte (c) embutida e polida para caracterização por metalografia.

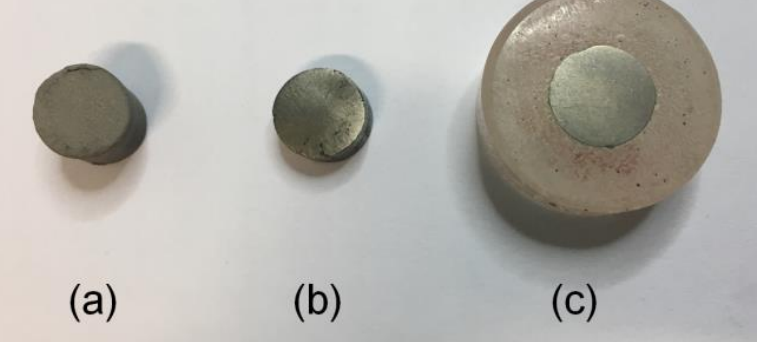

Fonte: criada de autor 
Os resultados alcançados nas amostras sinterizadas em forno elétrico e ao ar ficaram abaixo do desejado. A sinterização feita em forno industrial de esteira, em atmosfera com fluxo de gás com mistura $\left(\mathrm{N}_{2}-\mathrm{H}_{2}\right)$ comercial, resultou em amostras com baixa resistência mecânica. A utilização de forno à vácuo com atmosfera de gás redutor $\left(\mathrm{H}_{2}\right)$ forneceu melhores resultados de resistência mecânica e menor variação dimensional quando comparado com o uso de atmosfera protetiva, por meio do uso de gás argônio. A utilização do fluxo de arraste usando gás de proteção argônio (Ar) em forno tubular eliminou a oxidação superficial, observada em sinterização no forno convencional com atmosfera ar. As amostras obtidas com essa técnica de sinterização apresentaram os valores mais altos como resultado do teste de microdureza.

As sinterizações em forno a vácuo (pressões $\sim 10^{-2} \mathrm{~atm}$ ) em atmosfera redutora, contida com gás de hidrogênio $\left(\mathrm{H}_{2}\right)$ eliminou os problemas de reações de oxidação para as amostras do sistema W-Ni e W-Cu-Ni. Para as amostras do sistema W-Cu compostas por cobre eletrolítico apresentaram efeito de desagregamento e fissuras decorrente de oxidação.

\subsection{Atenuação da radiação gama}

As amostras obtidas na composição W10Cu1Ni, W8Cu1Ni e W6Cu1Ni apresentaram as propriedades desejadas para compor a estrutura de blindagem contra a radiação em equipamentos de transporte ou estacionário. Essas amostras foram selecionadas para os ensaios experimental de atenuação da radiação. Para os ensaios de atenuação foi aplicada a técnica de colimação de feixe estreito (Narrow Beam Collimated Geometry - NBCG). Para obter resultados experimentais da atenuação da radiação gama sobre as amostras selecionadas foi utilizada as fontes radioativas de Cobalto-60.

Os resultados dos ensaios são representados por gráficos de espectro de energia e tabelas que mostraram os dados em função da razão $\left(\mathrm{I}_{\mathrm{x}} / \mathrm{I}_{0}\right)$, onde $\left(\mathrm{I}_{0}\right)$ a contagem absoluta no detetor de fótons em livre caminho da fonte ao detector (da fonte). A contagem de fótons após a transmissão do feixe no meio material $\left(I_{x}\right)$ é a contagem absoluta dos fotos transmitidos através do meio material, após atenuação pela amostra. Os valores apresentados nos gráficos foram obtidos após a elaboração de calibração (canal x energia), dos detectores e dos equipamentos eletrônicos utilizados. 
A figura 5.61 ilustra o espectro de energia para livre caminho da radiação que contém os picos de energia do Cobalto-60 (1.173 keV e $1.332 \mathrm{keV})$, com os valores máximos de contagens no detector. Os espectros de energia com ensaios experimentais nas amostras de misturas e tabelas com a contagem de fótons $\mathrm{x}$ energia dos picos correspondentes indicam os valores de atenuação para cada amostra. Os valores da energia ensaiada diferem do valor de radiação gama do Molibdênio-99 em $140 \mathrm{keV}$ devem ser calculados, ajustados e normalizados por simulação no software XCOM (NIST).

Figura 5.61 Gráfico do espectro resultante do ensaio experimental, em tempo de 2000 segundos, ilustrativo dos valores de calibração canal em detetor e energia da radiação e como fonte a radiação de fundo (espectro de branco) para ajuste de contagens.

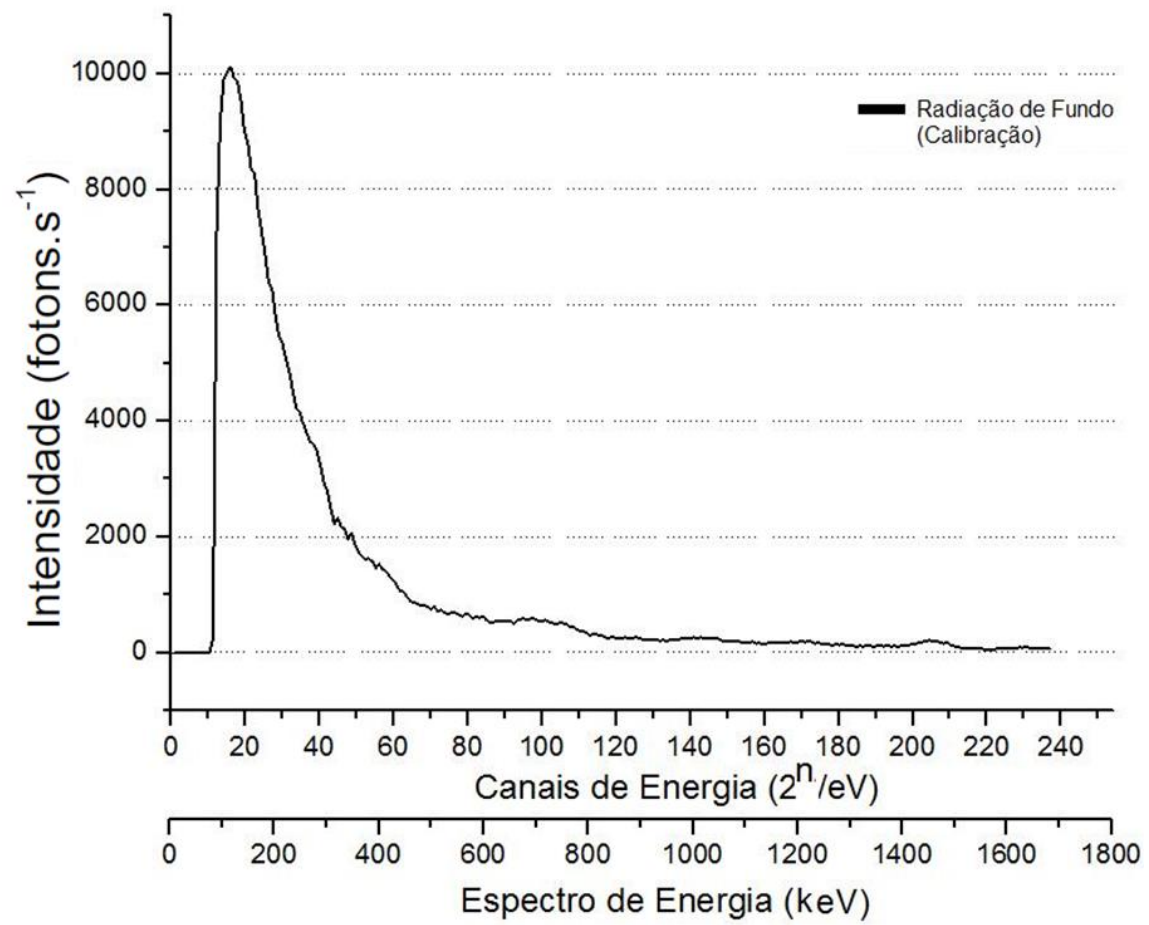

Fonte: criada de autor

O valor máximo obtido em emissão radiante é a atividade da fonte que é função da massa e da meia-vida do radionuclídeo (amplitude no espectro de energia). A energia radiante é propriedade característica do fóton (hv) do específico decaimento do radioisótopo (Cobalto-60 pico-1 $=1173 \mathrm{keV}$ e pico-2 $=$ $1332 \mathrm{keV})$. A razão de atenuação $I_{(x)} / I_{(0)}$ é valor que relaciona a intensidade incidente que é a emissão de fótons na origem da fonte $\left(\mathrm{I}_{(0)}\right)$ e a medida da intensidade transmitida em uma espessura definida no material absorvedor $\left(\mathrm{l}_{(\mathrm{x})}\right)$.

$O$ valor da relação $\left.\left(I_{(x)}\right)_{(0)}=1\right)$, neste caso, indica a inexistência de absorção de energia radiante pelo meio material. Quando um meio material 
(amostra) é posicionado entre o detector de radiação e a fonte de Co-60 ocorre atenuação que pode ser quantificada e definida como coeficiente linear de atenuação $(\mu)$ do material $[16,27,111]$.

O valor $\mathrm{I}_{(\mathrm{x})} / \mathrm{l}_{(0)}=0,5$ fornece a redução de radiação a $50 \%$ do valor para efeito de queda da radiação à sua metade inicial (Half Value Layer - $H V L$ ) que ocorre entre os picos de energia onde os fótons emitidos pela fonte caem em $50 \%$ dos fótons que chegam ao detector [109-111].

A figura 5.62 ilustra o ensaio experimental houve contagem de 9570 fótons emitidos com a energia de $1.173 \mathrm{keV}$ e 7011 fótons emitidos com a energia de $1.332 \mathrm{keV}$. Nos ensaios foi possível obter resultados com melhor precisão, fazendo repetições em varreduras com intervalos de $1.700 \mathrm{~s}$.

Figura 5.62 Gráfico do espectro resultante do ensaio experimental em tempo de 1700 segundos de atenuação da radiação ilustrando os dois picos (1173 keV, $1332 \mathrm{keV}$ ) para a fonte radioativa de Co-60 distante $100 \mathrm{~mm}$ do detector sem material de atenuação, livre caminho no ar.

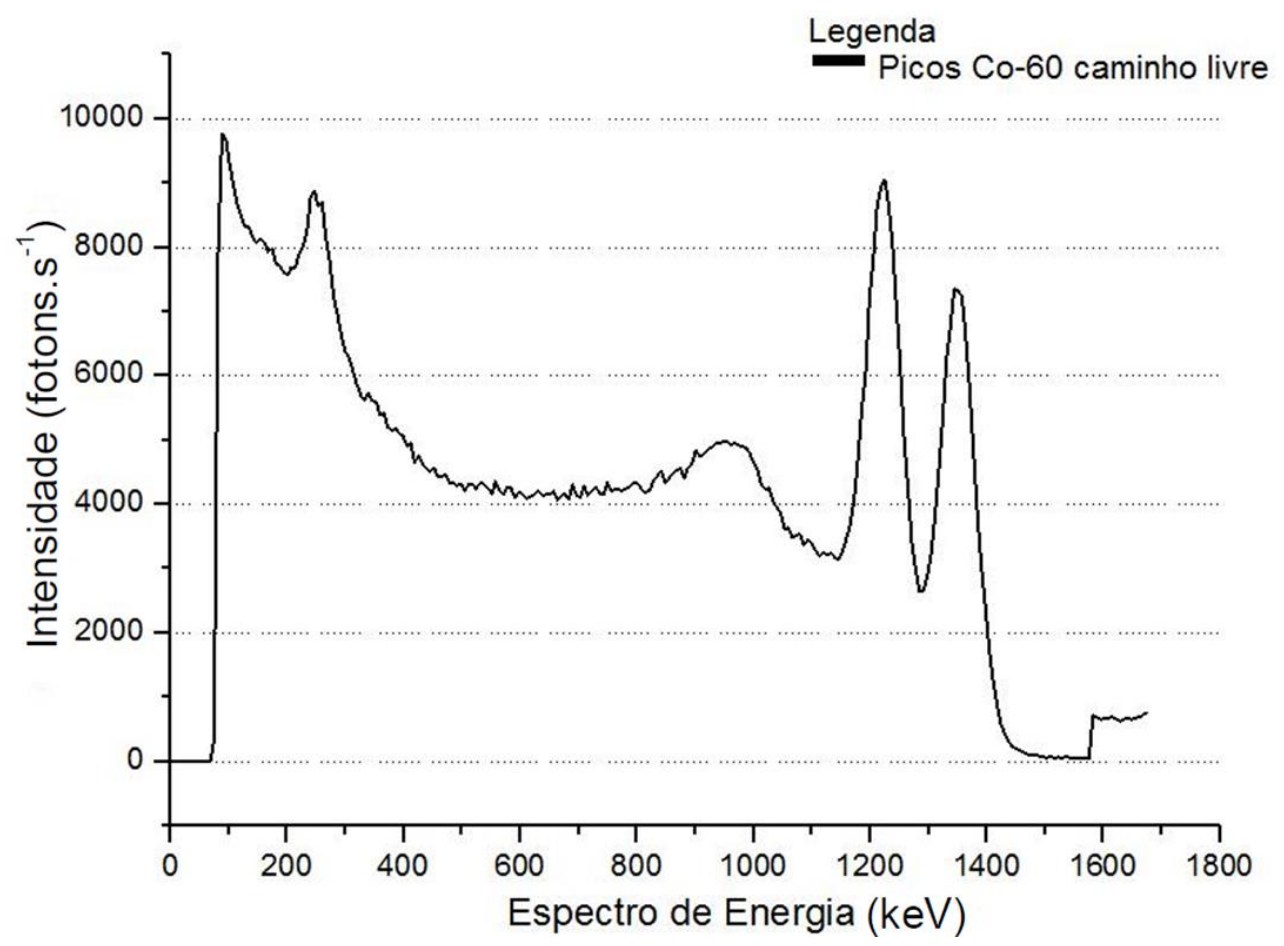

Fonte: criada de autor

Para melhor análise dos resultados em ensaios de atenuação da radiação devem ser considerados o coeficiente de atenuação linear $\left(\mu_{\text {mat }}\right)$ do material para a energia ou faixa de energia do fóton e o efeito físico predominante, como ilustra a figura 3.3 para as faixas de energia entre $100 \mathrm{keV}$ e $1400 \mathrm{keV}$.

A figura 5.63 apresenta o resultado do ensaio experimental da atenuação da radiação para a amostra de composição W10Cu1Ni. O valor de referência é o 
sinal de intensidade resultante da atenuação da amostra de tungstênio.

Figura 5.63 Gráfico do espectro resultante do ensaio experimental de atenuação da radiação da amostra W10Cu1Ni.

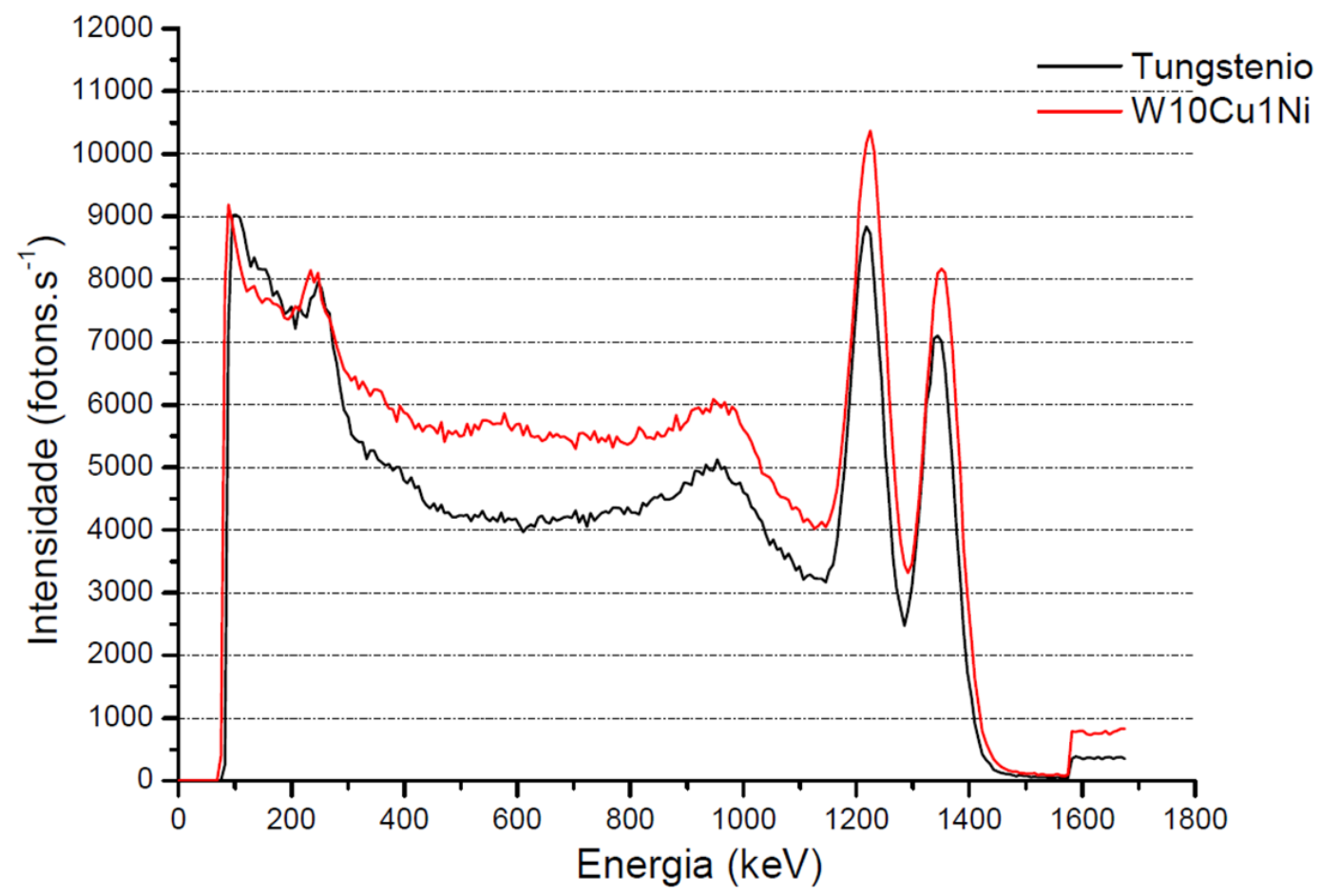

Fonte: criada de autor

A tabela 5.24 mostra os valores obtidos durante o tempo de 2000 s., no ensaio experimental de atenuação da radiação com fonte do cobalto-60 por feixe estreito para a amostra W10Cu1Ni com espessura de $10,0 \mathrm{~mm}$.

Tabela 5.24 Valores das intensidades obtidas para a média dos picos de energia da radiação do Cobalto-60 para as amostras W10Cu1Ni.

\begin{tabular}{|c|c|c|c|c|c|c|c|}
\hline $\begin{array}{l}\text { Amostra de } \\
\text { referência }\end{array}$ & $\begin{array}{l}\text { Densidade } \\
\text { teórica } \\
\left(\mathrm{g} \cdot \mathrm{cm}^{-3}\right)\end{array}$ & $\begin{array}{l}\text { Sinterizado } \\
\text { densidade } \\
\text { média } \\
\text { calculada } \\
\left({\left.\mathrm{g} . \mathrm{cm}^{-3}\right)}\right.\end{array}$ & $\begin{array}{l}\text { Fótons } \\
\text { total } \\
\left(I_{0}\right)\end{array}$ & $\begin{array}{l}\text { Fótons } \\
\text { transmitidos } \\
\left(\mathrm{I}_{\mathrm{x}}\right)\end{array}$ & $\begin{array}{l}\text { Razão de } \\
\text { atenuação } \\
\left(I_{x} / I_{0}\right)\end{array}$ & $\begin{array}{l}\text { Coeficiente } \\
\text { de } \\
\text { atenuação } \\
\text { massivo } \\
\left(\mathrm{cm}^{2} \mathrm{~g}^{-1}\right)\end{array}$ & $\begin{array}{l}\text { Coeficiente } \\
\text { Linear de } \\
\text { Absorção } \\
\mu_{\text {Tot }}\left(\mathrm{cm}^{-1}\right)\end{array}$ \\
\hline W10Cu1Ni & 18,26 & 10,31 & 9804 & 8909 & 0,909 & 0,954 & 0,9837 \\
\hline
\end{tabular}

Fonte: criada de autor

A figura 5.64 apresenta o resultado do ensaio experimental da atenuação da radiação para a amostra $\mathrm{W} 8 \mathrm{Cu} 1 \mathrm{Ni}$. O valor de referência é o sinal de intensidade resultante da atenuação da amostra de tungstênio. 
Figura 5.64 Gráfico do espectro resultante do ensaio experimental de atenuação da radiação da amostra W8Cu1Ni.

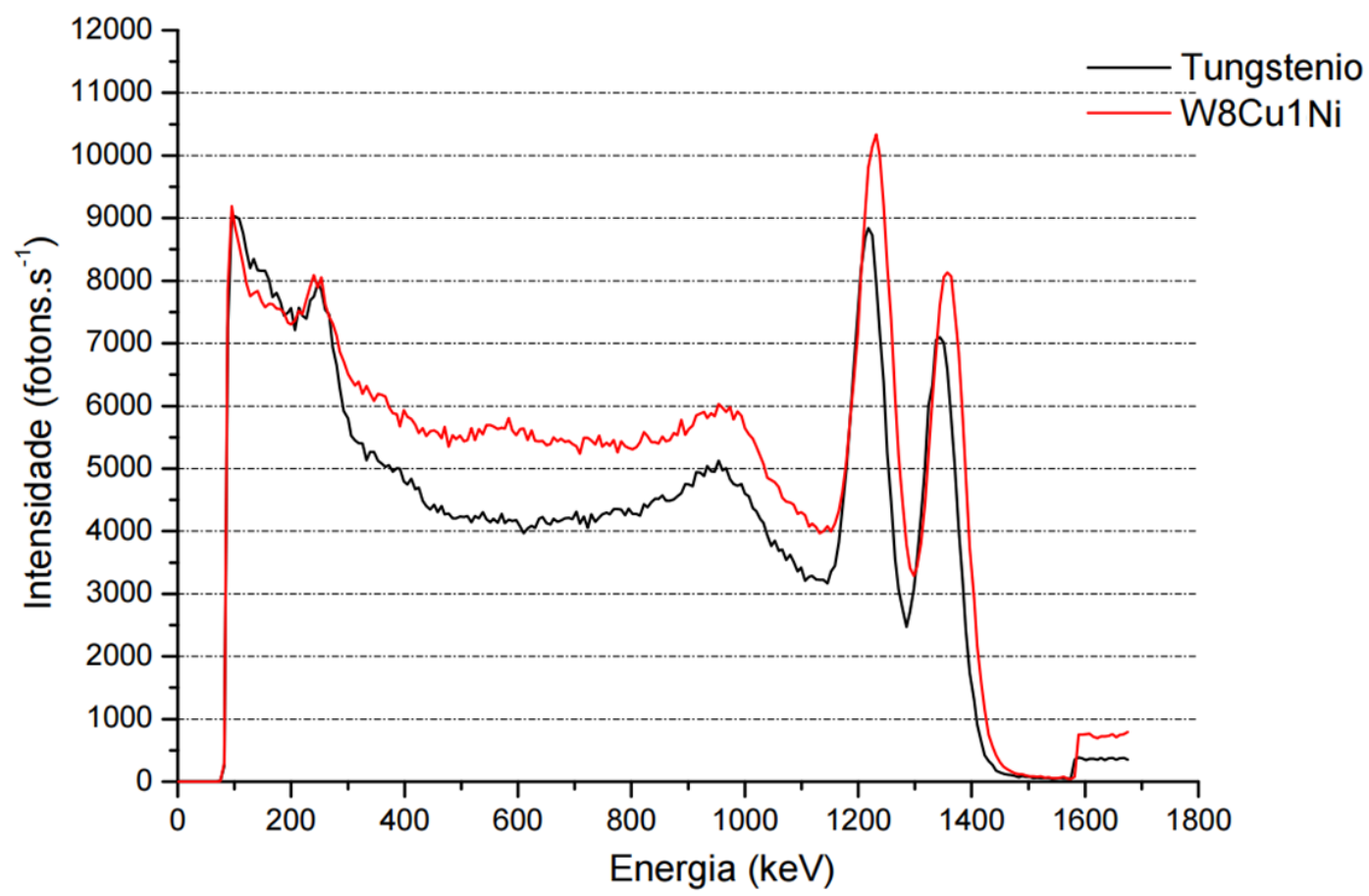

Fonte: criada de autor

A tabela 5.25 mostra os valores obtidos durante o tempo de 2000 s., no ensaio experimental de atenuação da radiação com fonte do cobalto-60 por feixe estreito para a amostra W8Cu1Ni com espessura de 10,0 mm.

Tabela 5.25 Valores das intensidades obtidas para a média dos picos de energia da radiação do Cobalto-60 para as amostras W8Cu1Ni.

\begin{tabular}{|c|c|c|c|c|c|c|c|}
\hline $\begin{array}{l}\text { Amostra } \\
\text { de } \\
\text { referência }\end{array}$ & $\begin{array}{l}\text { Densidade } \\
\text { teórica } \\
\text { (g.cm-3) }\end{array}$ & $\begin{array}{l}\text { Sinterizado } \\
\text { densidade } \\
\text { média } \\
\text { calculada } \\
\left(\mathrm{g} . \mathrm{cm}^{-3}\right)\end{array}$ & $\begin{array}{l}\text { Fótons } \\
\text { total } \\
\left(\mathrm{I}_{0}\right)\end{array}$ & $\begin{array}{l}\text { Fótons } \\
\text { transmitidos } \\
\left(\mathrm{I}_{\mathrm{x}}\right)\end{array}$ & $\begin{array}{l}\text { Razão de } \\
\text { atenuação } \\
\left(\mathrm{I}_{\mathrm{x}} / \mathrm{I}_{0}\right)\end{array}$ & $\begin{array}{l}\text { Coeficiente } \\
\text { de } \\
\text { atenuação } \\
\text { massivo } \\
\left(\mathrm{cm}^{2} \mathrm{~g}^{-1}\right)\end{array}$ & $\begin{array}{l}\text { Coeficiente } \\
\text { Linear de } \\
\text { Absorção } \\
\mu_{\text {Tot }}\left(\mathrm{cm}^{-1}\right)\end{array}$ \\
\hline W8Cu1Ni & 18,31 & 10,83 & 10544 & 8863 & 0,841 & 1,732 & 1,8753 \\
\hline
\end{tabular}

Fonte: criada de autor

A figura 5.65 apresenta o resultado do ensaio experimental da atenuação da radiação para a amostra de composição W6Cu1Ni. O valor de referência é o sinal de intensidade, resultante da atenuação da amostra de tungstênio.

Figura 5.65 Gráfico do espectro resultante do ensaio experimental de atenuação da radiação da amostra W6Cu1Ni. 


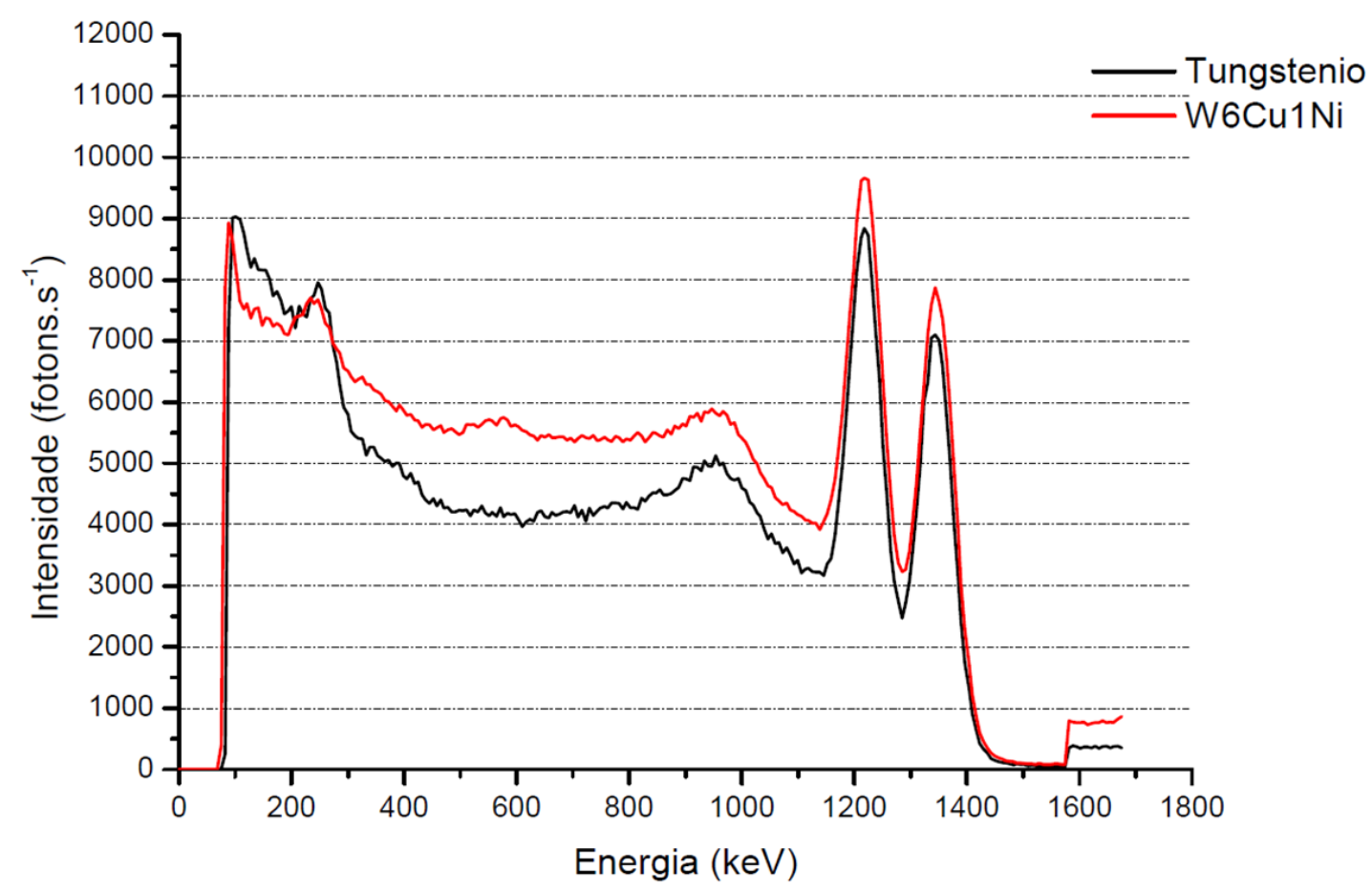

Fonte: criada de autor

A tabela 5.26 mostra os valores obtidos durante o tempo de 2000 s., no ensaio experimental de atenuação da radiação com fonte do cobalto-60, por feixe estreito para a amostra W6Cu1Ni com espessura de $10,0 \mathrm{~mm}$.

Tabela 5.26 Valores das intensidades obtidas para a média dos picos de energia da radiação do Cobalto-60 para as amostras W6Cu1Ni.

\begin{tabular}{|c|c|c|c|c|c|c|c|}
\hline $\begin{array}{l}\text { Amostra } \\
\text { de } \\
\text { referência }\end{array}$ & $\begin{array}{l}\text { Densidade } \\
\text { teórica } \\
\left(\mathrm{g} . \mathrm{cm}^{-3}\right)\end{array}$ & $\begin{array}{l}\text { Sinterizado } \\
\text { densidade } \\
\text { média } \\
\text { calculada } \\
\left(\mathrm{g} . \mathrm{cm}^{-3}\right)\end{array}$ & $\begin{array}{l}\text { Fótons } \\
\text { total } \\
\left(\mathrm{I}_{0}\right)\end{array}$ & $\begin{array}{l}\text { Fótons } \\
\text { transmitidos } \\
\left(\mathrm{I}_{\mathrm{x}}\right)\end{array}$ & $\begin{array}{l}\text { Razão de } \\
\text { atenuação } \\
\left(\mathrm{I}_{\mathrm{x}} / \mathrm{I}_{0}\right)\end{array}$ & $\begin{array}{l}\text { Coeficiente } \\
\text { de } \\
\text { atenuação } \\
\text { massivo } \\
\left(\mathrm{cm}^{2} \mathrm{~g}^{-1}\right)\end{array}$ & $\begin{array}{l}\text { Coeficiente } \\
\text { Linear de } \\
\text { Absorção } \\
\mu_{\text {Tot }}\left(\mathrm{cm}^{-1}\right)\end{array}$ \\
\hline W6Cu1Ni & 18,57 & 13,38 & 10027 & 8376 & 0,835 & 1,803 & 2,4127 \\
\hline
\end{tabular}

Fonte: criada de autor

A figura 5.66 apresenta o resultado do ensaio experimental da atenuação da radiação para a amostra de composição $\mathrm{W} 1 \mathrm{Ni}$. O valor de referência é o sinal de intensidade resultante da atenuação da amostra de tungstênio. 
Figura 5.66 Gráfico do espectro resultante do ensaio experimental de atenuação da radiação da amostra de composição W1Ni.

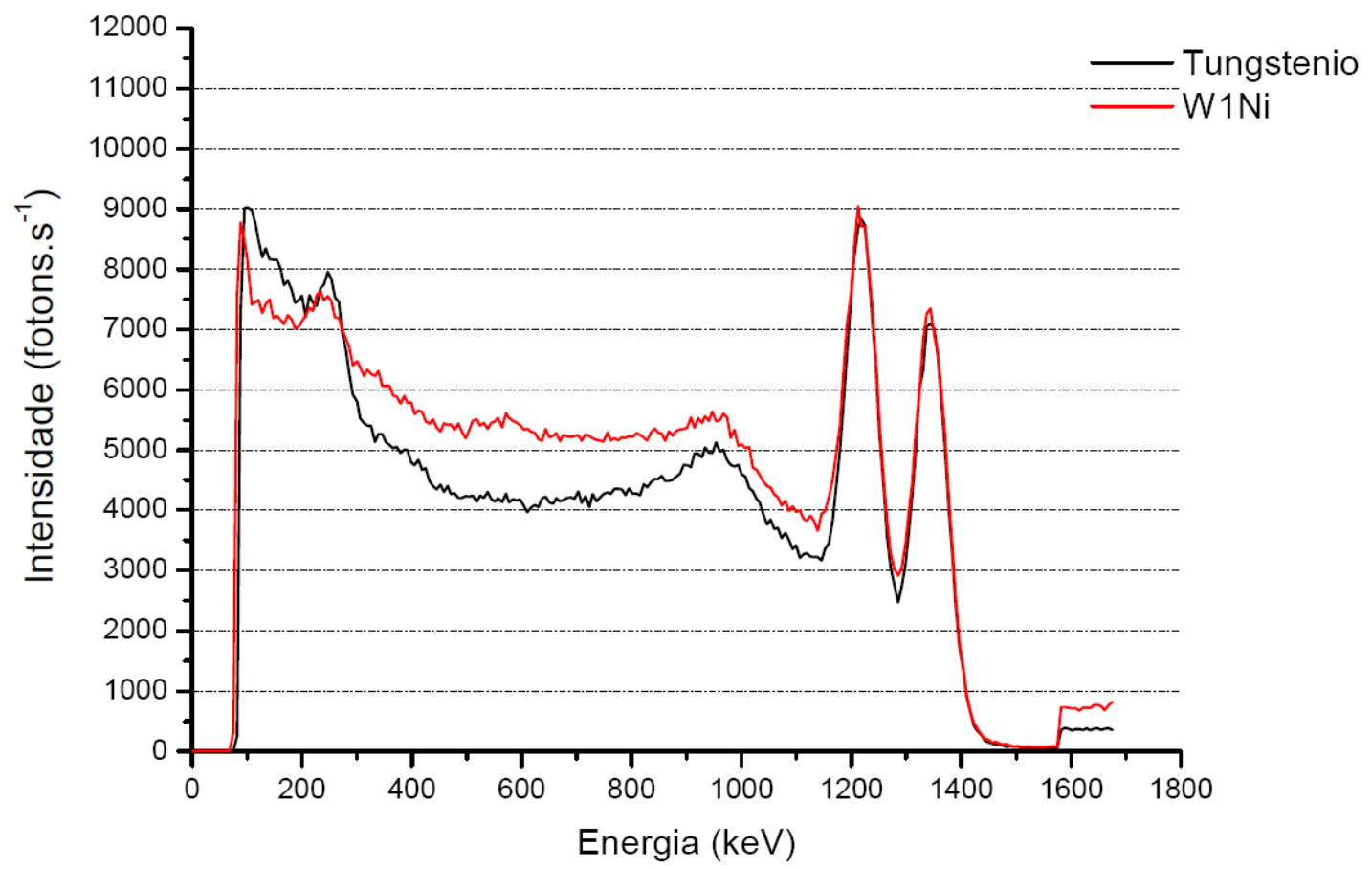

Fonte: criada de autor

A tabela 5.26 mostra os valores obtidos durante o tempo de 2000 s., no ensaio experimental de atenuação da radiação com fonte do cobalto-60 por feixe estreito para a amostra W1 Ni com espessura de 10,0 mm.

Tabela 5.27 Valores das intensidades obtidas para a média dos picos de energia da radiação do Cobalto-60 para as amostras W1Ni.

\begin{tabular}{|c|c|c|c|c|c|c|c|}
\hline $\begin{array}{l}\text { Amostra } \\
\text { de } \\
\text { referência }\end{array}$ & $\begin{array}{l}\text { Densidade } \\
\text { teórica } \\
\left(\mathrm{g} \cdot \mathrm{cm}^{-3}\right)\end{array}$ & $\begin{array}{l}\text { Sinterizado } \\
\text { densidade } \\
\text { média } \\
\text { calculada } \\
\left(\mathrm{g} . \mathrm{cm}^{-3}\right)\end{array}$ & $\begin{array}{l}\text { Fótons } \\
\text { total } \\
\left(\mathrm{I}_{0}\right)\end{array}$ & $\begin{array}{l}\text { Fótons } \\
\text { transmitidos } \\
\left(\mathrm{I}_{\mathrm{x}}\right)\end{array}$ & $\begin{array}{l}\text { Razão de } \\
\text { atenuação } \\
\left(I_{x} / I_{0}\right)\end{array}$ & $\begin{array}{l}\text { Coeficiente } \\
\text { de } \\
\text { atenuação } \\
\text { massivo } \\
\left(\mathrm{cm}^{2} \mathrm{~g}^{-1}\right)\end{array}$ & $\begin{array}{l}\text { Coeficiente } \\
\text { Linear de } \\
\text { Absorção } \\
\mu_{\text {Tot }}\left(\mathrm{cm}^{-1}\right)\end{array}$ \\
\hline W1Ni & 19,20 & 10,01 & 9899 & 8353 & 0,844 & 1,696 & 0,1697 \\
\hline
\end{tabular}

Fonte: criada de autor

A atenuação ocorre em função da porcentagem em massa de cada elemento da amostra $\mathrm{W}-\mathrm{Cu}-\mathrm{Ni}$ e sua respectiva densidade. O valor do coeficiente de atenuação linear através do ar, dos gases retido ou ausência de material no volume de vazios, ou poros são influenciados devido a estes fatores de redução da eficiência da atenuação, em decorrência da menor densidade da amostra. $O$ coeficiente de atenuação linear é função da energia. Cada elemento na amostra implica quantitativamente na atenuação da radiação e esse valor é dado pelo 
parâmetro de intensidade $\left(I_{L}\right)$ em cada energia (hu). Deste modo é possível comparar os valores experimentais obtidos para cada amostra e os valores teóricos calculados podendo assim determinar indiretamente a porosidade $\left(\mu_{\mathrm{ar}}\right)$ presente no material compósito, em função da atenuação esperada para a densidade teórica.

A tabela 5.28 mostra dados sobre as amostras dos materiais de referência mencionados com valores simulados pelo software WinXCOM (NIST) [21] da energia $150 \mathrm{keV}$ para aproximação aos raios gama emitidos pelo decaimento do Molibdênio-99 com energia de $140 \mathrm{keV}$ e da energia 1500 keV para aproximação aos raios gama emitidos pelo decaimento do Cobalto-60 com energia média de $1250 \mathrm{keV}$.

Tabela 5.28 Propriedades das amostras de referência (WinXCOM Database)

\begin{tabular}{|c|c|c|c|c|c|}
\hline \multirow{2}{*}{$\begin{array}{l}\text { Material } \\
\text { de } \\
\text { referência }\end{array}$} & \multirow[t]{2}{*}{ Elemento } & \multirow{2}{*}{$\begin{array}{l}\text { Densidade } \\
\text { teórica } \\
\left(\mathrm{g} . \mathrm{cm}^{-3}\right)\end{array}$} & \multirow[t]{2}{*}{$\begin{array}{l}\text { Massa Atômica } \\
\text { (u.m.a) }\end{array}$} & \multicolumn{2}{|c|}{$\begin{array}{l}\text { Coeficiente de atenuação } \\
\text { massivo }\left(\mathrm{cm}^{2} \mathrm{~g}^{-1}\right)\end{array}$} \\
\hline & & & & $150 \mathrm{keV}$ & $1500 \mathrm{keV}$ \\
\hline Chumbo (Pb) & 82 & 11,34 & 207,20 & 2,014 & 0,0522 \\
\hline Tungstênio (W) & 74 & 19,25 & 183,84 & 1,581 & 0,0500 \\
\hline
\end{tabular}

Fonte: criada de autor

A aplicação do fator de correção built-up (NIST) para o cálculo de blindagem para raios- $X$ e raios gama. A tabela 5.29 ilustra os valores de coeficiente linear de absorção $(\mu)$ em função da energia do fóton e do material absorvedor sem os necessários ajustes que devem ser aplicados no cálculo final da blindagem $[37,41]$.

Tabela 5.29 Coeficientes Linear de Absorção $(\mu)$ dos elementos utilizados na composição do sistema W-Cu-Ni relacionados por energia da radiação gama do cobalto-60 pelo database NIST [41].

\begin{tabular}{lll}
\hline $\begin{array}{l}\text { Energia da } \\
\text { radiação } \gamma(\mathrm{keV})\end{array}$ & Elemento & Valor $(\mu)$ \\
\hline 1.137 & Tungstênio & $1,058 \times 10^{2}$ \\
\hline 1.332 & Tungstênio & $5,00 \times 10^{-2}$ \\
\hline 1.137 & Cobre & $2,217 \times 10^{-1}$ \\
\hline 1.332 & Cobre & $5,264 \times 10^{-2}$ \\
\hline 1.137 & Níquel & $2,208 \times 10^{-1}$ \\
\hline 1.332 & Níquel & $5,015 \times 10^{-2}$ \\
\hline 1.137 & $\mathrm{Ar}$ & $1,00 \times 10^{-1}$ \\
\hline 1.332 & $\mathrm{Ar}$ & $2,05 \times 10^{-2}$ \\
\hline
\end{tabular}

Fonte: criada de autor 
A tabela 5.30 apresenta os valores de referência e resultado dos cálculos para o coeficiente HVL de atenuação onde foram consideradas as densidades e as concentração em massa de cada elemento nas amostras dos compósitos obtidos por uso da Eq. 13 ajustada.

Tabela 5.30 Valores comparativos de espessura para atenuação de camada semi-redutora (HVL) dos elementos referência e de composição do sistema W-Cu-Ni e W-Ni.

\begin{tabular}{lll}
\hline Amostra & $\begin{array}{l}\text { Densidade } \\
\left(\mathrm{g} . \mathrm{cm}^{-3}\right)\end{array}$ & $\begin{array}{l}\text { Valor de } \\
\mathrm{HVL} \\
(\mathrm{mm})\end{array}$ \\
\hline Tungstênio (NIST). & 19,25 & 7,90 \\
\hline Chumbo (NIST). & 11,34 & 12,5 \\
\hline Tungstênio Ref. (99,9\%) & 19,06 & 6,67 \\
\hline Chumbo Ref. (99,9\%) & 11,03 & 12.5 \\
\hline W10Cu1Ni & 10,31 & 10,89 \\
\hline W8Cu1Ni & 10,83 & 11,15 \\
\hline W6Cu1Ni & 13,38 & 9,27 \\
\hline W1Ni & 10,01 & 11,23 \\
\hline
\end{tabular}

Fonte: criada de autor

A atenuação da radiação gama obtida nos ensaios experimentais consideraram os picos de $1.137 \mathrm{keV}$ e $1.332 \mathrm{keV}$ do radioisótopo Co-60. Para obter o valor de espessura da camada semi-redutora (HVT) usando os materiais compósitos propostos foi usado o valor médio de energia (1.250 keV) dos picos. 


\section{CONCLUSÃO}

Das amostras produzidas do sistema W-Cu, W-Cu-Ni e W-Ni as amostras obtidas com composição inédita W6Cu1Ni e aplicadas à atenuação da radiação apresentaram os melhores resultados. As características físico-químicas apresentadas pela composição W6Cu1Ni apresentam densidade e dureza compatíveis ao metal tungstênio. A densidade alcançada no compósito W6Cu1 $\mathrm{Ni}$ é de $13,38 \mathrm{~g} . \mathrm{cm}^{-3}$, superior quando comparada a densidade do chumbo 11,03 $\mathrm{g} . \mathrm{cm}^{-3}$, material de uso geral em blindagem contra a radiação.

O valores para HVL (NIST) para o tungstênio é $7,90 \mathrm{~mm}$ e o valor para HVL obtido para o compósito W6Cu1 $\mathrm{Ni}$ é 9,27 mm, sendo de 12,5 mm para o chumbo, indicando melhor característica para blindagem. A temperatura de fusão do chumbo é $600,6{ }^{\circ} \mathrm{C}$ [NIST] e a temperatura de fusão experimental para o compósito W6Cu1Ni é $890{ }^{\circ} \mathrm{C}$, característica necessária para blindagem à radiação em equipamentos de transporte de radiofármacos. Os resultados obtidos para as características finais de densidade média $\left(13,0 \mathrm{~g}^{\mathrm{cm}}{ }^{-3}\right)$, dureza média (303 HV) e os valores do coeficiente camada semi-redutora (HLV) de 9,27 mm na energia de $1.250 \mathrm{keV}$ permite concluir que o compósito pode ser utilizado como material alternativo para blindagem da radiação gama.

O uso do moinho de esferas mostrou eficiência para a redução do tamanho médio das partículas do pó tungstênio (de $63 \mu \mathrm{m}$ para $45 \mu \mathrm{m}$ ) que resultou no aumento da taxa de empacotamento.A utilização combinada do moinho de bolas como misturador dos pós da composição auxiliaram na homogeneização da mistura e redução do tamanho de partícula na composição resultou em maior densificação do compactado verde.

Para o sistema W-Cu-Ni os teores (massa) de cobre entre $8,0 \%$ e $6,0 \%$ e do níquel entre 2,0\% e 1,0\% maximizaram as características mecânicas e de atenuação.A sinterização com fase líquida dos pós de cobre e níquel ancoraram as partículas do tungstênio formando aglomerados densos, sólidos e de boa rigidez.

A utilização da técnica de sinterização com fase líquida com a liga Cu-Ni apresenta vantagens para a redução na temperatura de sinterização e consequente redução de custo na produção dos compósitos.

Na composição em massa de cobre entre 5,0\% Cu e 15,0\% do diagrama de fase do binário CuNi é obtido os requisitos mínimos que atendem parâmetros 
de forno para temperaturas próxima de $1.400^{\circ} \mathrm{C}$. para sinterização do sistema WCu-Ni.Essas características fazem do compósito W6Cu1Ni o material alternativo para ser utilizado como material de blindagem da radiação gama. 


\section{SUGESTÃO PARA TRABALHOS FUTUROS}

Como extensão deste estudo fica proposto a aplicação de análises de análises térmicas DTA, DSC e dilatometria, com objetivo de conseguir maior densificação no sistema W-Cu-Ni. Estes ensaios térmicos experimentais em compósitos metálicos são pouco divulgados na literatura especializada. Os resultados obtidos poderão auxiliar no maior entendimento da mecânica de sinterização e oxidação do tungstênio à baixas temperaturas.

O metal tungstênio quando utilizado como matriz nos compósitos dos sistemas $\mathrm{W}-\mathrm{Ni}, \mathrm{W}-\mathrm{Cu}, \mathrm{W}-\mathrm{Cu}-\mathrm{Ni}, \mathrm{W}-\mathrm{C}$, pode oferecer parâmetros e características favoráveis para sinterização em temperatura considerada baixa (aproximadamente $1200^{\circ} \mathrm{C}$ ). $\mathrm{O}$ uso destes outros pós de metal como elementos de sinterização fase líquida sugerem oferecer compósitos com maior dureza e maior resistência mecânica.

O estudo da metalurgia do pó na obtenção de materiais alternativos para aplicações na área nuclear, em particular a proteção contra a radiação, apresenta vantagens como os aspectos ecológicos em relação ao chumbo, material tradicionalmente destinado a essa finalidade além de proporcionar produção a baixo custo com economia de energia e quantidade mínima de material residual. 


\section{REFERÊNCIAS BIBLIOGRÁFICAS}

[1] MENGATTI, J.; O Estado da Arte na Produção de Radiofármacos no Brasil; Relatório de Gestão IPEN / Comissão Nacional de Energia Nuclear CNEN; 201405-08, Radiofarmácia; São Paulo, SP; 2013

[2] Bula Gerador IPEN-TEC Profissional da Saúde; Disponível em: $<$ https://www.ipen.br/portal_por/conteudo/geral/1555_290_BULA\%20GERADOR\% 20IPEN-TEC\%20Profissional\%20da\%20saude.pdf>; Acessado as 19:35 h em 16 de setembro de 2017.

[3] EL-SIBAIE M.; Certificate 0562/B (U) For Package Design Approval - Revision 2 for GANUK Model GA-01; German Authority US Department of Transportation Pipeline and Hazardous Materials Safety Administration; Washington, DC; 2010.

[4] ROKROK B.; MOVAFEGI, A.; EDALATI, K.; KERMANI, A.; SEIEDE, N.; RASTKHAH; Monte Carlo Simulation of Scattering Phenomenon Effects on Industrial Radiography; NIST \& NDT Resource Center, Radioprotection Technological Center; Tehran, Iran; 2006.

[5] AQUINO A. R.; VIEIRA, M. M. F.; Molibdênio-99, crise e oportunidade; Scientific American Brazil, Duetto Editorial; Ed. 98, ISBN:16769791; 2010.

[6] DANTAS, V.; Uma Crise Anunciada: pode faltar molibdênio-99 em 2016; Brasil Nuclear, Informativo da Associação Brasileira de Energia Nuclear; pagina 11, Número 42; 2014.

[7] Constituição da República Federativa do Brasil de 1988. Disponível em: <https://senado.gov.br./atividade/const/cons1988/con1988_06.06.2017/art_7ao.as > Acessado as 19:35 h em 10 de junho de 2017.

[8] HARA, D. H. S.; Seleção de Materiais para Embalado de Transporte de Mo-99; Dissertação de Mestrado, Biblioteca Eletrônica da USP, São Paulo, SP, Brasil; 2015.

[9] Termo de Referência Norma 30.1 CNEN - Controle da Atividade de Transporte de Materiais Radioativos no Brasil; CNEN; São Paulo, SP, Brasil; 2007.

[10] Termo de Referência Norma NE 5.01,Resolução 13/88 CNEN - Transporte De Materiais Radioativos; Comissão Nacional de Energia Nuclear (CNEN);, Agosto; 1988.

[11] PADILHA, F. A.; Licenciamento De Instalações Radiativas; Termo de Referência Norma CNEN NN 6.02 - CNEN São Paulo, SP, Brasil; 2014; disponível em:

$<$ http://appasp.cnen.gov.br/seguranca/normas/normas.asp?grupo=6 $>$ Acessado as 08:45 h em 20 de junho de 2017.

[12] Agência Nacional de Transportes Terrestres (ANTT); Resolução 420, de 12 de fevereiro de 2004; Regulamento do Transporte de Produtos Perigosos; São Paulo, SP, Brasil; 2004; disponível em:

<http://www.sbpc.org.br/upload/conteudo/320110405154556.pdf >Acessado as 14:15 h em 25 de junho de 2017.

[13] Agência Nacional de Aviação Civil (ANAC) Resolução RBAC 175; Transporte de Artigos Perigosos em Aeronaves Civil; 2009; disponível em:

$<$ http://appasp.cnen.gov.br/seguranca/transporte/documentos/ANAC-RBAC-175>; 
Acessado as 09:25 h em 29 de junho de 2017.

[14] FIALHO, F. A. B.; Agência Nacional de Transportes Aquaviários (ANTAq) Resolução 1765 ; Norma de Procedimentos Para o Trânsito Seguro de Produtos Perigosos por Instalações Portuárias Situadas Dentro ou Fora da Área do Porto Organizado; Brasil; 2010; disponível em:<http://web.antaq.gov.br/portalv3/pdfSistema/Publicacao/0000002675>; Acessado as 20:05 h em 2 de julho de 2017.

[15] Conselho Nacional do Meio Ambiente (CONAMA); Resolução 237, de 19 de dezembro de 1997; Procedimentos e Critérios para o Licenciamento Ambiental; disponível em: < http://www.mma.gov.br/port/conama/res/res97/res23797.html>; Acessado as 20:05 h em 2 de julho de 2017.

[16] ANDRADE H. V.; Licenciamento Ambiental e Lei Complementar No.140/2011; Advocacia Pública Federal; Distrito Federal, Brasília; 2014.

[17] Occupational Radiation Protection; Safety Standards Series; RS-G-1.1, Safety Guide; International Atomic Energy Agency (IAEA); Vienna, Austria; 1999.

[18] Regulations For The Safe Transport Of Radioactive Material, Safety Standard Series, TS-R-1, VIC; Library Cataloguing in Publication Data; International Atomic Energy Agency (IAEA); Vienna, Austria; 2000.

[19] VALENTIN, J.; Recommendations for Radiological Protection; Publication 103 of International Commission on Radiological Protection; Annals of the ICRP; Elsevier; 2007.

[20] Radioactivity Standard Reference Materials; Radiation Physics Division, Physical Measurement Laboratory, NISTIR 5632, NIST; 2016.

[21] HUBELL, J. H., SELTZER, S. M.; X-Ray Mass Attenuation Coefficients; RPDP-15; Radiation Physics Division, Physical Measurement Laboratory, NIST; 1996.

[22] Diretrizes Básicas De Proteção Radiológica; Comissão Nacional de Energia Nuclear (CNEN); Resolução 164/14, Março; 2014

[23] Requisitos De Segurança E Proteção Radiológica Para Serviços De Radioterapia; Comissão Nacional de Energia Nuclear (CNEN); Resolução 6.10, Março; 2017

[24] VALENTIN, J.; ICRP Publication 103; The 2007 Recommendations of the International Commission on Radiological Protection; ICRP Publication 103. In. ICRP 37, ICRP; ELSEVIER Pub; 2007.

[25] OKUNO, E.; YOSHIMURA, E.; Física Das Radiações; Editora São Paulo; SP, Brasil; 2010.

[26] OKUNO, E.; Radiação Efeitos, Riscos E Benefícios; Editora HARBRA; São Paulo, SP, Brasil; 1998.

[27] OKUNO, E., VILELA, M. A. C.; Radiação Ultravioleta, Características e Efeitos; Editora e Livraria da Física; ISBN 8588325314; São Paulo, SP, Brasil; 2005.

[28] EISBERG, R.; RESNICK, R.; Física Quântica átomos, Moléculas, Sólidos, Núcleos e Partículas; Ed. Campus Ltda.; Rio de Janeiro, RJ, Brasil; 1998.

[29] SERWAY, R. A.; MOSES, C. J.; MOYER, C. A.; Modern Physics; Books Cole Thomson Learning Academic Resource Center; Belmont, CA, 94002, USA; 2005 
[30] TíPPLER, P. A.; Física para Cientistas e Engenheiros, Quarta edição, Volume 3; LTC-Lívros Técnicos e Científicos Editora S/A; Rio de Janeiro, RJ, Brasil; 2000

[31] SERWAY, R. A.; Principles of Physics; Library of Congress Catalog Card Number 93-087099; Saunders College Publishing; Orlando, FI, USA; 1992.

[32] PROFIO, A. E.; Radiation Shielding and Dosimetry; Willey Interscience Publications; Toronto, Ontario, CA; 1979.

[33] FENIMORE, E. E.; GALASSI, M.; Gamma-Ray Burst Symposium; American Institute of Physics; AIP Conference Proceedings; Santa Fe, NM, USA; 2003

[34] CLARCK, G. L.; Encyclopedia of X-Rays and Gamma Rays; University of Illinois; Reinhold Publishing Corporation; Urbana, IL, USA; 1993.

[35] MINNITI, R.; SHOBE, J.; SELTZER, S. M.; MAYER, H. C.; DOMEN, S. R.; Absorbed Dose to Water Calibration of lonization Chambers in a Co-60 GammaRay Beam; Physics Laboratory, NIST; Gaithersburg, MD, USA; 2006.

[36] CHU, S. Y. F.; EKSTROM, L. P.; FIRESTONE, R. B.; The LBNL Nuclear Database, Department of Physics; Lund University, Sweden; 1995.

[37] KNOLL, G. F.; Radiations Detection and Measurement, John Wiley and Sons; Washington DC, VA, USA; 1979.

[38] STORM, E.; ISRAEL, H.; Photon Cross Section from 0,001 to $100 \mathrm{MeV}$ for Elements 1 to 100, Los Alamos Scientific Laboratory report LA 3753; 1967; USA..

[39] ABBOTT, L. S.; CLAIBORNE, H. C.; CLIFFORD, C. E.; Weapons Radiation Shielding Handbook Methods for Calculating Neutron and Gamma Ray Attenuation, Cap. 3; Defense Atomic Support Agency; Washington DC, USA; 1968.

[40] McAlister, D. R.; Gamma Ray Attenuation Properties of Common Shielding Materials; PG Research Foundation; University of Lane Lisle, IL; USA; 2012.

[41] NDT Resource Center; Transmitted Intensity Linear Attenuation Coefficient; $<$ https://www.ndeed.org/EducationResources/CommunityCollege/Radiography/Ph ysics/attenuationCoef.htm>; Acessado em: 12 de setembro de 2017 as 11:35 h.

[42] MINGLE, J. O.; The Invariant Imbedding of Nuclear Transport Modern Analytic and Computational Methods in Science and Mathematics; Elsevier, New York City, NY, USA; 1973.

[43] RAGHEB, M., Attenuation of Gamma Radiation and Build-Up Factor; United State of America; Department of Commerce, Springfield, VA; 2001.

[44] DAVIS, W. K.; The Attenuation of Gamma Rays and Neutrons in Reactor Shields; United States Atomic Energy Commission;, White Plains, New York, USA; 1957.

[45] HABBEI, J. H.; Photon Cross Section Attenuation Coefficients and Energy Absorption Coefficient from $10 \mathrm{keV}$ to $100 \mathrm{GeV}$.; National Bureau of Standards; report NSRDS-NSB 20, Los Alamos VA, USA; August 1969.

[46] Interação da Radiação com a Matéria;

<http://www.iaea.org/inis/collection/NCLCollectionStore/_Public/45/073/45073468. pdf> disponível as 15:03 $\mathrm{h}$ do dia 20/12/2017.

[47] CHEN, S.; BOURHAM, M.; RABIEI, A.; Attenuation Efficiency Of X-Ray and Comparison to Gamma Ray And Neutrons In Composite Metal Foams; 
Department of Mechanical and Aerospace Engineering, North Caroline State University, Raleigh, NC, USA; 2015.

[48] CONNER, A. L.; ATWATER, H. F.; PLASSMANN, E. H.; MCCRAY, J. H.; Gamma Ray Attenuation-Coefficient and Measurements; University of California, American Physical Society; Los Alamos, NM, USA; 1970.

[49] XU, S.; BOURHAM, M.; RABIEI, A.; A Novel Ultra-Light Structure for Radiation Shielding; Materials and Design; v 31, p. 2140-2146; Elsevier; 2010.

[50] MOREIRA, A. C.; APPOLONI, A. R.; Determinação do Coeficiente de Atenuação de Massa de Amostras da Superfície de Marte, da Lua e da Terra, no Intervalo de $1 \mathrm{keV}$ a $100 \mathrm{GeV} ; 2005$ International Nuclear Atlantic Conference INAC2005; Santos, SP, Brazil; ISBN: 85-99141-01-5; 2005.

[51] THRALL, J. H.; ZIESSMAN, H. A.; Nuclear Medicine The Requisites, Second Edition; Mosby Health Science Company; Philadelphia, PL, USA; 2001.

[52] Radioisotopes in Medicine; World Nuclear Associations; Disponível em: $<$ http://www.world-nuclear.org/information-library/non-power-nuclearapplications/radioisotopes-research/radioisotopes-in-medicine.aspx>; Acessado em 22 de outubro de 2017 as 21:35 h.

[53] DETREECH, H.; Radiotherapy Protection; <https://www.ndeed.org/EducationResources/CommunityCollege/Radiography/Ph ysics/attenuation.htm> Acessado em: 17 de junho de 2017 as 15:15 h.

[54] LIMEDE, P. I. B. J. M.; Caracterização das Qualidades de Radiação X de Diagnóstico, Segundo a Norma Internacional IEC 61267; Dissertação de Mestrado em Engenharia Biomédica; Universidade Nova de Lisboa, Portugal; 2010.

[55] CHANDRA, R.; Nuclear Medicine Physics: The Basics; Williams \& Wilkins Ed.; Ed. 5; Baltimore, MD, 1998.

[56] CLINTON, H. M., WITCOFSKI, R. L.; Nuclear Pharmacy: An Introduction to the Clinical Application of Radiopharmaceuticals; Ed. Lea \& Febigger; Philadelphia, $\mathrm{Pa}$,USA; 1986.

[57] CIONE, F. C.; SOUZA, A. C.; RIZZUTTO, M. A.; SENE, F. F.; ROSSI, J. L.; A Study of Production of Tungsten Copper Alloy by Powder Metallurgy, Applied to Radioactive Shielding of Transport Equipment for Pharmaceutical Products; Euro PM2015 - Powder Metallurgy for Current and Future Applications; Rheims, France; 2015.

[58] OHNO, A.; Solidificação de Metais; CBMM; Livraria Ciência e Tecnologia Editora Ltda.; UNICAMP; Perdizes, São Paulo, SP, Brasil; 1988.

[59] CALLISTER, W. D.; Materials Science and Engineering: An Introduction; University of Utah, Department of Metallurgical Engineering; John Wiley \& Sons, Inc.; Asia Edition; 7th. Edition; York, PA, USA; 2007.

[60] MURR, L. E.; Structure of Metals and Alloys; Handbook of Materials Structures Properties Processing and Performance; Springer Intl.; Switzerland; 2014.

[61] ASKELAND, D. R.; The Science and Engineering of Materials; Second Edition, PWS-Kent Publishing Company; University of Missouri; MI, USA; 1989.

[62] COSTA, F. A.; Síntese e Sinterização de Pós Compósitos do Sistema W-Cu; Tese de Doutoramento; USP-IPEN; São Paulo, 2004. 
[63] NEVES, M. D. M.; Sinterização de Misturas de Pós de Ligas de Ferro Para Aplicações Automotivas; Tese de Doutoramento; USP-IPEN; São Paulo, 2005

[64] BARBOSA, L. P; Caracterização Quanto À Corrosão de Filtros de Aço Inoxidável AISI 316 Sinterizados; Dissertação de Mestrado; USP-IPEN; São Paulo, 1999.

[65] SMITHELLS, C. J., Tungsten a Treatise on Its Metallurgy, Properties and Applications; Chapman \& Hall Ltd.; London, UK; 1945.

[66] HIRSCHHO, R. N.; Introduction to Powder Metallurgy; New York; American Powder Metallurgy Institute; 1969.

[67] DAWIHL, W.; Handbook of Power Metallurgy, Second Edition; Chemical Publishing Co. Inc., Saarland; New York City, NY, USA; 1982.

[68] GERMAN, R. M.; Powder Metallurgy Science, Second Edition; Metal Powder Industries Federation; Princeton, NJ, USA; 1994.

[69] GERMAN, R. M.; Powder Metallurgy Particulate Materials Processing; Metal Powder Industries Federation; Princeton, NJ, USA; 2005.

[70] GERMAN, R. M.; Lower Sintering Temperature Tungsten Alloys for Space Research; International Journal of Refractory Metals and Hard Materials; DOI 2015.04.020; Elsevier; 2015.

[71] DOWSON, G.; Powder Metallurgy The Process And Its Products; Adam Hillger Press; Bristol, New York, USA; 1990.

[72] SCHWARZKOPF, P.; Powder Metallurgy Its Physics and Production; Macmillan Company; New York, NY, USA; 1947.

[73] SHAKESPEARE, C. R.; SANDS, R. L.; Powder Metallurgy Practice and Applications; William Cloves and Sons Limited; London, UK; 1966.

[74] KUHN, H. A.; LAWLEY, A.; Powder Metallurgy Processing New Techniques and Analyses; Academic Press; New York City, NW, USA; 1978.

[75] REDDY, R. G.; ANTONY L. V. M.; Processes for Production of High - Purity Metal Powders; Journal of the Minerals; Metals and Materials Society. 14 - 18 ; 2003.

[76] SLOTWINSKI, J. A.; GARBOCZI, E. J.; STUTZMAN, P. E.; FERRARIS; WATSON, C. F. S.; PELTZ, M. A.; Characterization of Metal Powders Used for Additive Manufacturing; Journal of Research of the National Institute of Standards and Technology; National Institute of Standards and Technology (NIST), Gaithersburg, MD, USA, 2014.

[77] ASTM, B761 - 06 (Reapproved 2011): Standard Test Method for Particle Size Distribution of Metal Powders and Related Compounds by X - Ray Monitoring of Gravity Sedimentation; 2011.

[78] ASTM, B215-10: Standard Practices for Sampling Metal Powders; 2011 [79] Hoganas Handbook for Sintering Components: Metallography; Copyright Hoganas; AB, Sweden; 2007

[80] JILLAVENKATESA, A.; DAPKUNAS, S. J.; LUM L. S. H.; Particle Size Characterization; NIST SP 960, Washington D.C.; 2001.

[81] ASTM, B214-07: Standard Test Method for Sieve Analysis of Metal Powders; 
Acessado em; <https://www.astm.org/DATABASE.CART/HISTORICAL/B21407.htm> na data de 24/11/2017 ás 17:30.

[82] ASTM, B215-16: Standard Test Method for Sieve Analysis of Metal Powders, Mesh designation Number, Particle Size, Screened Fraction for US Standard ; Acessado em: < https://www.astm.org/DATABASE.CART/HISTORICAL/B21407.htm > na data de 24/11/2017 ás 17:30 h.

[83] ASTM, B212-09: Standard Test Method for Sieve Analysis of Metal Powders; Acessado em: <https://www.astm.org/DATABASE.CART/HISTORICAL/B21407.htm> na data de 24/11/2017 ás 17:30 h.

[84] ASTM, B417-11: Standard Test Method for Apparent Density of Free-Flowing Metal Powders Using Hall Flow meter Funnel; Acessado em: <https://www.astm.org/DATABASE.CART/HISTORICAL/B214-07.htm > na data de 2/6/2017 ás 9:50 h.

[85] ASTM, B527-06: Standard Test Method for Determination of Tap Density of Metallic Powders and Compounds; Acessado em:

$<$ https://www.astm.org/DATABASE.CART/HISTORICAL/B214-07.htm> na data de 2/6/2017 ás 9:50 $\mathrm{h}$.

[86] BIANCANIELLO, F. S.; CONWAY, J. J.; ESPINA, P. I.; MATTINGLY; RIDDER, G. E.; Particle Size Measurement of Inert Gas Atomized Powder; Materials Science and Engineering; Elsevier; 1990.

[87] BARRET, P. J.; The Shape of Rock Particles, a Critical Review; Journal of Sedimentology. 27 (3), 291 - 303; 1980.

[88] ASKELAND, D. R.; The Science and Engineering of Materials; Second Edition; University of Missouri, Rolla; PWS-Kent Publishing Company; Boston, MS, USA; 1989.

[89] PIOTTER, V.; ZEEP, B.; NORAJITRA, P.; RUPRECHT, R.; Von der WETH, A.; HAUSSELT, J.; Development of a Powder Metallurgy Process for Tungsten Components; Fusion Engineering and Design, vol 83, pgs 1517-1520; 2008

[90] JONES, D. J.; MUNNERY, P.; Production of Tungsten Alloy Penetration Radiation Shields; The Role of Powder Metallurgy in Nuclear Technology; Central Research Laboratory of General electric Co., Wembley, London, UK; 1967.

[91] GATTI, A.; Method For Sintering Tungsten Powder; United State Patent Office, Patented 3,116,146; General Electric Company; New York, NY; 1963.

[92] TOTH, I. J.; LOCKINGTON, N. A.; The Kinetics of Metallic Activation Sintering of Tungsten; Department of Metallurgy and Materials Technology, University of Surrey, London, GB; 1966.

[93] GERMAN, R. M.; SURI, P.; SEONG, J. P.; Review: Liquid Phase Sintering; Journal of Mater Science; Springer Science; DOI 10.1007/s10853-008-3008-0; 2008.

[94] YUNXIN, W., GERMAN, R. M., MARX, B., BOLLINA, R., BELL, M.; Characteristics of Densification and Distortion of Ni-Cu Liquid-Phase Sintered Tungsten Heavy Alloy; Pennsylvania State University; Materials Science \& Engineering; Elsevier Science Inc.; 2003.

[95] IHN, T. H.; LEE, S. W.; JOO, S. K.; Effect of Transition Metal addition on Liquid Phase Sintering of W-Cu; Powder Metallurgy; vol. 37; i. 4; 1994. 
[96] PANICHKINA, V. V.; SIROTYUK, M. M.; SKOROKHOD, V. V.; Liquid-Phase Sintering of Very Fine Tungsten-Copper Powder Mixtures; Theory and Technology of Sintering, Thermal, and Chemicothermal Treatment Process; Plenum Publishing Corporation, Institute of Material Science, Poroshkovaya, Ukrainian; 1981.

[97] NABEEL, M.; Diffusion of Elemental Additives During Sintering; Royal Institute of Technology; Department of Materials Science and Engineering, Division of Physical Metallurgy; Stockholm, Sweden; 2016.

[98] BARTH, V. D.; Mclntyre, H. O.; Tungsten Powder Metallurgy, National Aeronautics and Space Administration (NASA); Columbus, OH, USA; 1965.

[99] LI, Y., YU, S.; Thermal-Mechanical Process in Producing High Dispersed Tungsten-Copper Composite Powder; International Journal of Refractory Metals \& Hard Materials; Science Direct; Elsevier; 2007.

[100] HAYDEN, H. W.; BROPHY, J. H.; Low Temperature Sintering of Pure Tungsten and Tungsten-Iridium; Department of Metallurgy, Massachusetts Institute of Technology, Cambridge, MA, USA; 1963.

[101] HAMIDI, A.; G., ARABI, H.; RASTEGARI, S.; A Feasibility of W-Cu Composites Production By High Pressure Compression of Tungsten Powder; International Journal of Refractory Metals and Hard Materials no. 29; Elsevier; 2011.

[102] CHANTHAPAN, S.; KULKARNI, A.; SINGH, J.; HAINES, C.; KAPOOR, D.; Sintering of Tungsten Powder With and Without Tungsten Carbide Additive By Field Assisted Sintering Technology; International Journal of Refractory Metals and Hard Materials, vol. 31, pgs 114-120; Elsevier; 2012.

[103] MENG, Y.; SHEN, Y.; CHEN, C.; LI, Y.; FENG, X.; Microstructures and Formation Mechanism of W-Cu composite coatings on Copper Substrate Prepared by Mechanical Alloying Method; Applied Surface Science 282; Elsevier; 2013.

[104] EROGLU, S., BAYKARA, T.; Effects of Powder Mixing Technique and Tungsten Powder Size on Proprieties of Tungsten Heavy Alloys; Journal of Materials Processing Technologies, no. 193, pgs 288-292; Elsevier; 2000.

[105] BOSE, A.; Net Shaping Concepts for Tungsten Alloys and Composites; Powder Metallurgy, vol. 64, i. 2, 2003.

[106] OQAIL, A. A.; GHANIM, M.; SHEIKL, M. E.; NIKHAILY, A. E.; Effects of Processing Parameters of Tungsten-Copper Composites; International Journal of Refractory Metals and Hard Materials, vol. 35, pgs 207-212, Elsevier; 2012.

[107] HAMIDI, A. G.; RASTEGARI, S.; ARABI, H.; Tungsten-Cooper Composite Production by Activated Sintering and Infiltration; Journal of REFRATORY Metals and Hard Materials; Elsevier, Tehran, Iran; 2011.

[108] YBARRA, L. A. C.; MOLISANI, A. L.; RODRIGUES, D.; YOSHIMURA, H. N; Efeitos das Características dos Pós Industriais de Tungstênio e Carboneto de Tungstênio na Microdureza e Dureza de Metal Duro Para Ferramentas De Perfuração De Rochas; Revista Eletrônica de Materiais e Processos, REMAP, V.3.2, p. 10-25, ISSN 1809-8797; 2008.

[109] TAUBENBLAT, P. W.; SMITH, W. E.; EVANS, C. E.; Production of P/M Parts from Copper Powder; Precision Metal 30(4):41; 1972. 
[110] SUBRAMANIAN, P. R.; LAUGHLIN, D. E.; Phase Diagram of Binary Tungsten Alloys Cu-W (Copper-Tungsten); Edition S.V. Nagender Naidu and Rama Rao, Indian Institute of Metals, pgs 76-79, Calcutta; 1991.

[111] MILNER, D. R.; NELSON, R. J.; Liquid Flow Densification in the Tungsten Carbide Copper System; Powder Metallurgy; vol. 14, i. 27; 1971; Birmingham; UK; 1971.

[112]ARSHAD, K.; WANG, J.; YUAN, Y.; ZHANG, J. Z.; LU, G. H.; Development of Tungsten Based Materials by Different Sintering Techniques; International Journal of Refractory Metals and Hard Materials, vol. 50, pgs 253-257; Elsevier; 2015.

[113] HARA, Z.; AKECHI, K.; Electrical Resistance Sintering of Titanium Alloys and Composites; Institute of Industrial Science; University of Tokyo, Tokyo, Japan; 1980.

[114] CDA Publication TN31; Copper-Nickel 90/10 and 70/30 Alloys Technical Data; Copper Development Association, UK; Sept 1982.

[115] DONGGUO, L.; HAN, J. S.; KWON, Y. S.; HA, S.; BOLLINA, R.; PARK, S. J.; High-Temperature Compression Behavior of W-10wt\%Cu Composite; International Journal of Refractory Metals and Hard Materials; Elsevier; 2015.

[116] BELK, J. A.; EDWARDS, M. R.; FARREL, W. J.; MULLAH, B. K.; Deformation Behaviour of Tungsten-Copper Composite; Technical Note; DG Pettior and AH Cortell, Courtel House; London; 1993.

[117]CHEN, C. L.; MA, S. H.; Study on characteristics and sintering behavior of W$\mathrm{Ni}$-Co Tungsten Heavy by a Secondary Ball Milling Method; Department of Science and Engineering; Hualien University, Taiwan; Journal of Alloys and Compounds, 2018.

[118] CHEN, C. L.; HSUN, S. M.; Effects of Ni-Co ratio and mechanical alloying on characteristics and sintering behavior of $\mathrm{W}-\mathrm{Ni}$-Co tungsten heavy alloys;

Department of Science and Engineering; Hualien, Taiwan; Journal of Alloys and Compounds, 2017.

[119] NELSON, R. J.; MILNER, D. R.; Liquid Flow densification in the Tungsten Carbide-Cooper System Department of Industrial Metallurgy; University of Birmingham; Birmingham, UK; 1971.

[120] OZKAL, B.; UPADHYAYA, A.; OVEÇOGLU, M. L.; GERMAN, R. M.; Comparative Properties Of $85 \mathrm{~W}-15 \mathrm{Cu}$ Powders Prepared Using Mixing, Milling an Coating Techniques;

[121] OZER, O.; MISSIAEN, J. M.; MITTEAU, R.; Processing Of Tungsten/Copper Materials from W-CuO Powders Mixtures; Materials Science \& Engineering, vol. 460-461, pg 525-531; Elsevier; 2007.

[122] ILLER, E.; WAWSZCZAK, D.; KONIOR, M.; MOTRENKO, H. P.; MILCZAREK, J. J.; GÓRSKY, L.; Synthesis and Structural Investigations of Gel Metal Oxide Composites WO3-ZrO2, WO3-TiO2, WO3-ZrO2-SiO2, and Their Evaluations as Materials For Preparation of 188W/188Re Generator; Applied Radiation and Isotopes, vol. 75, pgs 115-127, SCIVerse Science Direct; Elsevier; 2013.

[123] MENG, Y.; SHEN, Y.; CHEN, C.; LI, Y.; FENG, X.; Microstructures and Formation Mechanism of W-Cu Composite Coating on Cooper Substrate Prepared by Mechanical Alloying Method; Nanjing University, Nanjing; PR, China; 2013. 
[124] MATTHEWS, P. E.; Cubraloy, A New Development in Aluminum Bronze Powder Metallurgy; Proc. Fall 1971 Powder Metallurgy Conference; Metal Powder Industries Federation, Nevada; 1971.

[125] AGRAWAL, A.; HABIBI, H.; Effect of Heat Treatment On The Structure, Composition And ElectroChromic Properties Of Evaporated Tungsten Oxide Films; Donnelly Corporation; Holland, MI; USA; 1988.

[126] FEHLNER, F. P.; MOTT, N. F.; Low-Temperature Oxidation; Oxidation in Metals, Vol. 2 I. 1; 1970.

[127] YVANOV, V. Y.; NECHIPORENKO, Y. P.; YEFIMENKO, L. N.;

YURCHENKO, M. I.; High Temperature Oxidation on Tungsten; National

Aeronautics and Space Administration, NASA Technical Translation, NASA TT-E583; Washington, D.C., USA; 1969.

[128] JAMES, A. E.; CONRAD, R. B.; HOPE, D. A.; Process For Obtaining A Composite Material And Composite Material Obtained By Said Process; United State Patent Number 4,505,060; Inco Limited, Toronto, Canada; 1985.

[129] WOJCIK, P. J.; SANTOS, L.; PEREIRA, L.; MARTINS, R.; FORTUNATO, E.; Supporting Information to Tailoring Morphology and Structure of Tungsten Oxide Nanoparticles for Inkjet Printed Electrochomic Devices; Departamento de Ciência dos Materiais, Faculdade de Ciências e Tecnologia da Universidade de Lisboa (UNL); Caparica, Portugal; 2014.

[130] COUBE, O.; RIEDEL, H.; Numerical Simulation of Metal Powder Die Compaction With Special Consideration of Cracking; Fraunhofer Institut Fur Werkstoffmechanik; Wohlerstr.11; Freiburg, Germany; 1999.

[131] SLOTWINSKI, J. A.; GARBOCZI, E. J.; HEBENSTREIT, K. M.; Porosity Measurements and Analysis for Metal Additive Manufacturing Process Control; Journal of Research of the National Institute of Standards and Technology; National Institute of Standards and Technology (NIST); Gaithersburg, MD, USA; 2014.

[132] FAST, J. D.; Interaction of Metals and Gases Thermodynamics and Phase Relations; Academic Press; New York; NY; USA; 1965.

[133] JONES, D. A.; Principles and Prevention of Corrosion; Second Edition; Prentice HallUpper Sidle River; NJ.; USA; 1992.

[134] ALVAREZ, I. R.; TORAL, M. T.; LEMUS, A. F.; Química General e Inorganica para Estudiantes Universitarios; Editora Dossat, Plasa Sta. Ana, Madrid, Spain; 1950.

[135] ACCHAR, W., GOMES, U. U., KAYSSER, W. A., GORING, J.; Strength Degradation of a Tungsten Carbide-Cobalt Composite at Elevated Temperatures; Materials Characterization 43-, 27-32, Elsevier Science Inc., 1999.

[136] AGREN, J.; Oxidation and Diffusion in Oxides - A Progress Report; Royal Institute of Technology; NIST Diffusion workshop, 2012.

[137] HUBERTUS, C.; Metalografia dos Produtos Siderúrgicos Comuns; Universidade de São Paulo (USP); Editora Edgard Blucher Ltda.; São Paulo, SP, Brasil; 1974.

[138] KINGERY, W. D.; BOWEN, H. K.; UHLMANN, D. R.; Introduction to Ceramics 2nd ed.; John Wiley \& Sons; Academic Press.; ISBN 0-471-47860-1, 
NY, USA; 1976.

[139] BOCKSTIEGEL, G.; Handbook for Sintered Components Hoganas, Material and Powder Properties; Hoganas Press; AB; Sweden; 2004.

[140] SOUZA, S. A.; Ensaios Mecânicos de Materiais Metálicos Fundamentos Teóricos e Práticos, 5ta. Edição; Editora Blucher; São Paulo, SP, Brasil; 2009.

[141] FIGUEIRA FILHO, D. T. A.; Dureza de Corpos Sinterizados; BS Indústria e Comércio de Produtos Metalúrgicos LTDA; 2016.

[142] LILIUS, K. R., GASIK, M. M., JARVELA, V. P., STROMBERG, S.; Studies of infiltration By Apparent Thermogravimetry; Journal of Thermal Analysis, Vol. 40, Pg 915-922, John Wiley \& Sons; Springer Link; Budapest; 1993. 